\title{
A PROTEOMIC ANALYSIS OF THE EFFECTS OF YESSOTOXIN AND DI-DESULFOYESSOTOXIN ON YEAST AND MAMMALIAN CELLS
}

By

Sarah Cordiner

\begin{abstract}
A thesis
submitted to the Victoria University of Wellington

in fulfilment of the requirements for the degree of
\end{abstract}

Master of Biomedical Science

Victoria University of Wellington

2012 


\section{ACKNOWLEDGMENTS}

"You can't rush science, Gibbs. You can yell at it and scream at it, but you can't rush it."

Abby Sciuto; NCIS season 1, episode 14

First and foremost I would like to acknowledge and thank my supervisor, Dr. Bill Jordan. His willingness to help and his guidance have been indispensable over the course of this project.

I am grateful also to C. Miles and A.D. Hawkes (AgResearch Limited, Ruakura Research Centre, Hamilton, New Zealand) for the supply of toxins. My thanks also go to Dr. Brian Monk, (Department of Oral Sciences, University of Otago, Dunedin, New Zealand) for providing the pump knock-out mutant yeast, and to Professor John $\mathrm{H}$. Miller (School of Biological Sciences, Victoria University of Wellington, Wellington, New Zealand) for providing the HL60 cells.

I would like to extend my heartfelt gratitude to Dr. Pisana Rawson for teaching me the majority of skills and techniques that $\mathrm{I}$ would require for this project and her willingness to impart advice and help when requested - even from the other side of the world. The same applies to Dr. Jonathan Dunne, who has suffered merciless questioning on everything from gel electrophoresis to mass spectrometry with saintlike patience. I am also very grateful to Danyl McLauchlan for his help with virtually everything technical.

The chemical genetics lab, particularly Bede Busby and Ploi Yibmantasiri, were incredibly helpful for both the practical and theoretical parts of the work with yeast. I would also like to thank Ariane Chan from John Miller's group for teaching me the intricacies of tissue culture. My thanks are also extended to Dr. David Bellows, and Professors Paul Atkinson and John H. Miller for allowing me to work in their respective labs.

For their company, support, empathy, humour, and aid, I would like to thank my lab mates; Hannah "Chuckles" Hoang and Claire "3 days: 5 proteins" Swain, and the other 
inhabitants of the $3^{\text {rd }}$ floor of the Alan MacDiarmid Building. You have helped me keep my sanity... or at least made the descent into madness less noticeable.

Last, but not least, I would like to thanks my parents. Who, despite advising me at the start of my tertiary studies to do business or languages having both completed PhD's in science, have supported me whole-heartedly none-the-less.

"Perseverance conquers all." 


\section{ABSTRACT}

Yessotoxin (YTX) is a disulfated polycyclic polyether, produced by dinoflagellate algae. It is known to accumulate in edible shellfish, raising concerns about its potential risk to human health. YTX was initially classified as a diarrhetic shellfish poisoning toxin, due to commonly being extracted alongside toxins of this variety. However, YTX does not induce any of the effects characteristic of this group. A separate category for YTXs was established by the European Commission in 2002 and a limit of $1 \mathrm{mg} / \mathrm{kg}$ of shellfish meat was established.

YTX has been shown to be an apoptosis inducer in a variety of cell lines in vitro. It has also been shown to be lethal to mice when administered by intra-peritoneal injection. However, when administered orally only limited toxicity is observed. The di-desulfated derivative (dsYTX) has also been shown to be lethal to mice following intra-peritoneal injection. However it causes damage mainly to the liver, whereas YTX appears to target the heart. The mechanism of action of YTX is still unknown.

The goals of this project were to use proteomic techniques, to examine the effects of YTX and dsYTX on Saccharomyces cerevisiae and human promyelocytic leukemic blood leukocyte (HL60) cells. Young et al. (2009) showed that the major proteins affected by YTX in HepG2 cells were heterogeneous ribonucleoproteins (hnRNPs), lamins, cathepsins and heat shock proteins. HnRNPs had not previously been identified as possible targets of YTX. Alterations of hnRNP levels were also seen in HL60 cells treated with microtubule stabilising agents, peloruside A or paclitaxel (Wilmes et al., 2011, 2012).

No differences in cell morphology or significant changes in protein abundance were observed when S. cerevisiae cells were exposed to YTX. A small number of significant changes in abundance were detected when these cells were exposed to dsYTX. The small number of protein changes seen is possibly due to poor toxin entrance into the cell through the yeast cell wall, lack of protein targets structurally homologous to those found in mammalian cells, or fast removal of the toxin through export pumps. 
Twenty-four hour incubation of HL60 cells with YTX resulted in increased cell death but no change in cell morphology. Treatment with dsYTX caused cells to aggregate into clusters and a $24 \%$ decrease in the number of live cells. Increases were found in the abundance of $\beta$-actin, hnRNP A and BiP proteins in response to dsYTX treatment. Decreases in these proteins were seen in HepG2 cells treated with YTX for 24 hours. As seen in S. cerevisiae cells, dsYTX had a greater effect in HL60 cells compared with YTX.

Overall, the results provide some support for the previously identified effect on hnRNPs in mammalian cells exposed to YTX. 


\section{ABBREVIATIONS}

1DE

2DE

ABC

BiP

BSA

b.w.

CHCA

DIGE

DSP

dsYTX

DTT

DTX

FCS

FDR

GRP

hnRNP

HSP

IAA

IEF

i.p. one-dimensional gel electrophoresis

two-dimensional gel electrophoresis

adenosine triphosphate binding cassette

binding immunoglobulin protein

bovine serum albumin

body weight

a-cyano-4-hydroxycinnamic acid

differential in gel electrophoresis

diarrhetic shellfish poisoning

di-desulfoyessotoxin

dithiothreitol

dinophysistoxin

fetal calf serum

false discovery rate

glucose-regulated protein

heterogeneous nuclear ribonucleoprotein

heat shock protein

iodacetamide

isoelectric focusing

intraperitoneal 
IPA

LC-MS

LSP

MALDI-TOF MS

MALDI-TOF/TOF MS/MS

MTX

OA

PARP

PBS

Pel A

PI

PTP

PTX

SDS-PAGE

TCR

TFA

YPD

YTX
Ingenuity Pathways Analysis

liquid chromatography - mass spectrometry

ladder-shaped polyether

matrix assisted laser desorption/ionisation - time of

flight mass-spectrometry

matrix assisted laser desorption/ionisation - time of flight tandem mass spectrometry

maitotoxin

okadaic acid

poly(ADP-ribose)polymerase

phosphate buffered saline

peloruside $A$

propidium iodide

permeability transition pore

paclitaxel

sodium dodecyl sulphate - polyacrylamide gel

electrophoresis

T-cell receptor

trifluoroacetic acid

yeast peptone dextrose

yessotoxin 


\section{TABLE OF CONTENTS}

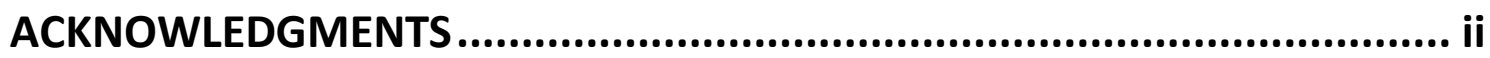

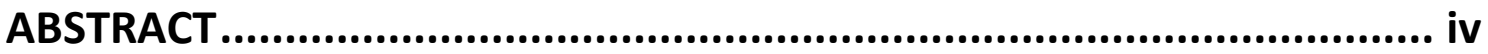

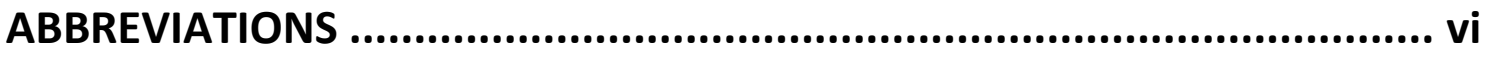

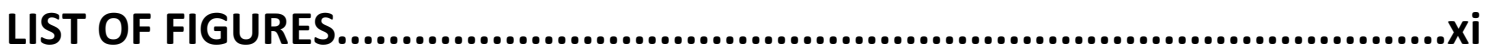

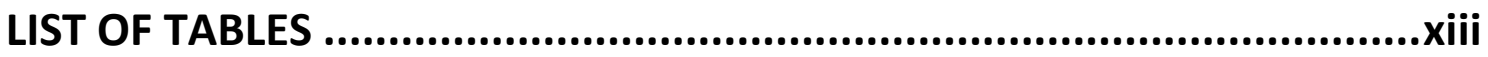

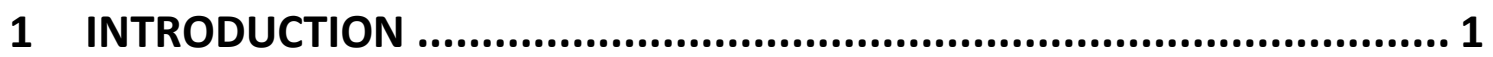

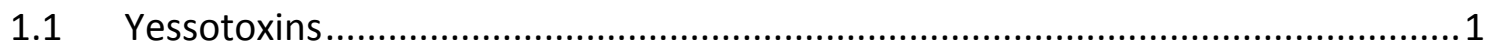

1.2 Algal production and shellfish metabolism.................................................... 1

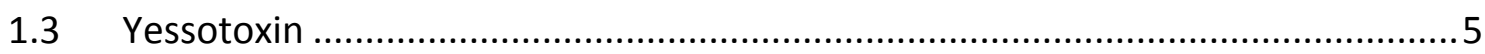

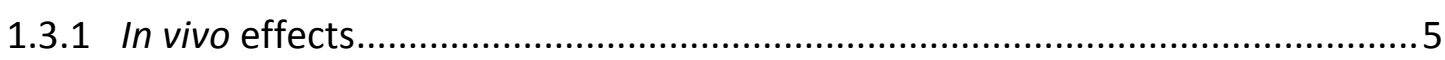

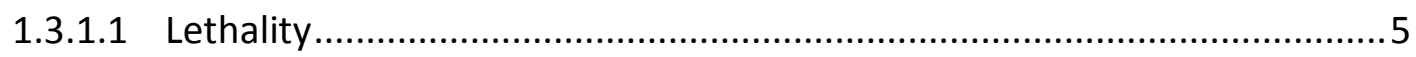

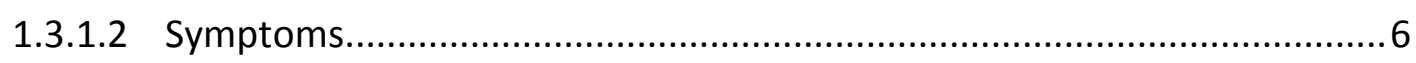

1.3.1.3 Morphological and histological analysis ............................................ 6

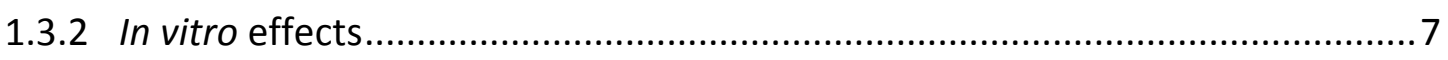

1.3.2.1 Anti-microbial action ........................................................................ 7

1.3.2.2 Cell death and morphological changes ................................................ 7

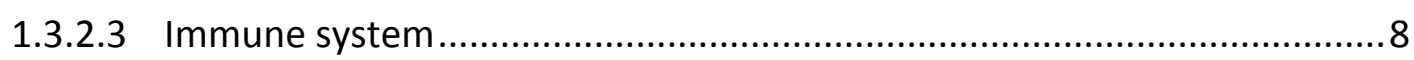

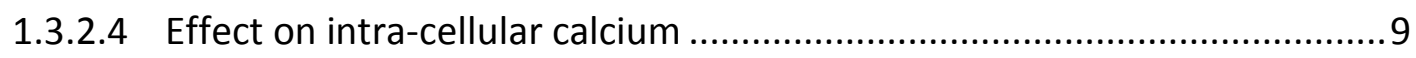

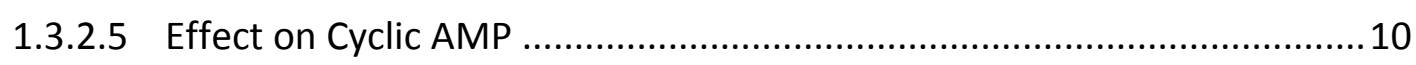

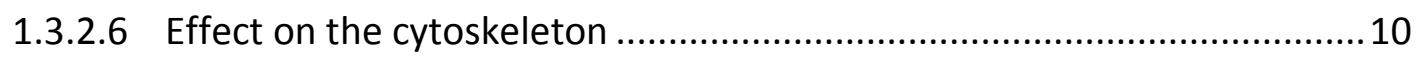

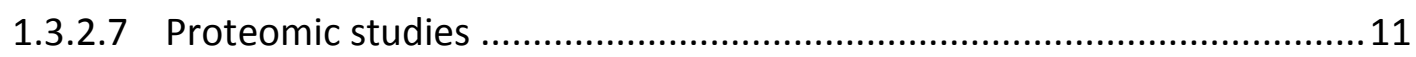

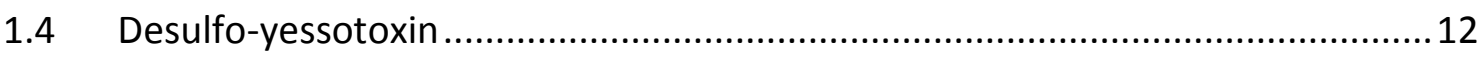

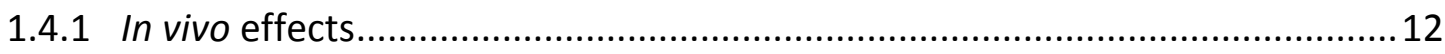

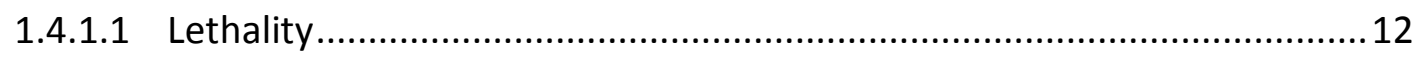

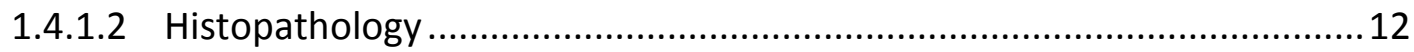

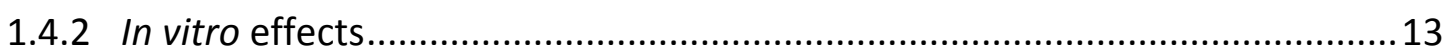

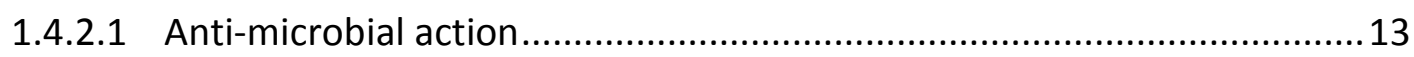

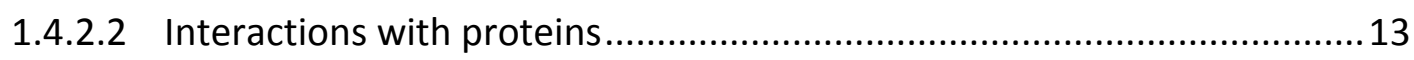

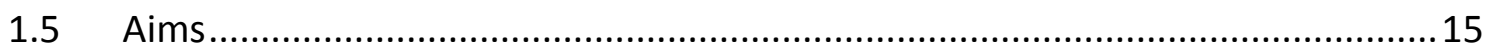

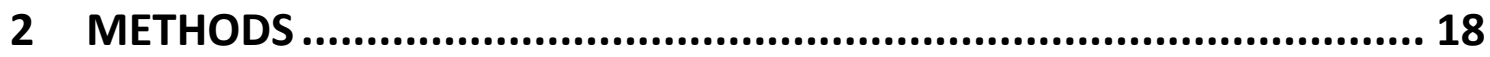

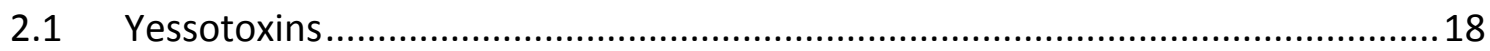

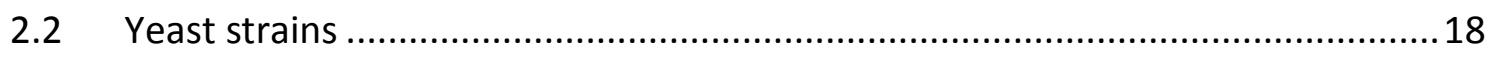




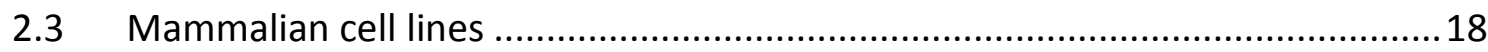

2.4 Yeast cell culture and protein extraction ..................................................... 18

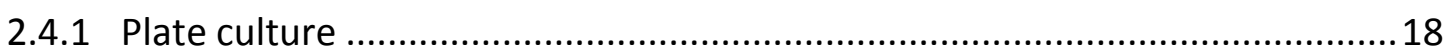

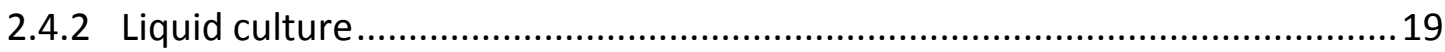

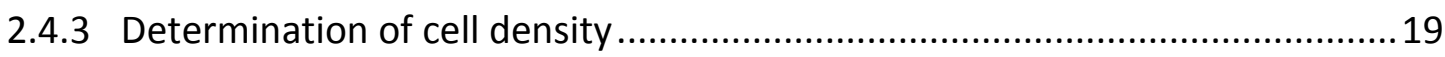

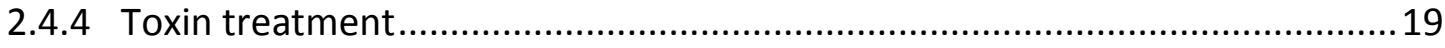

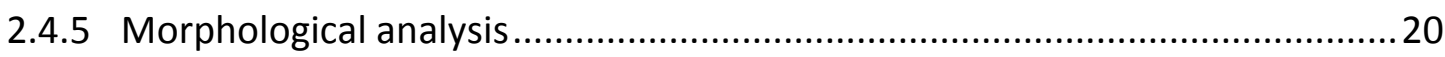

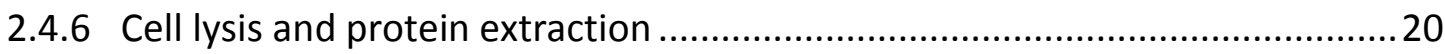

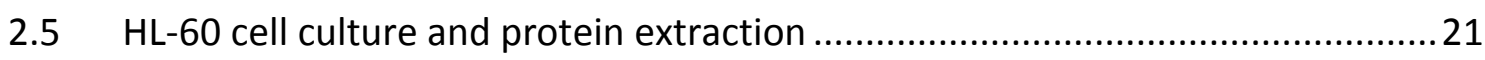

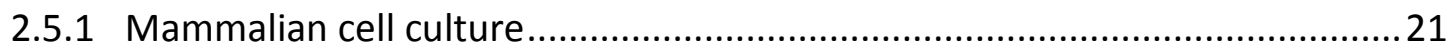

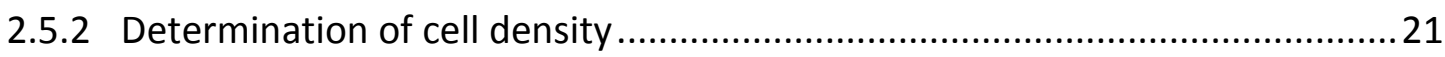

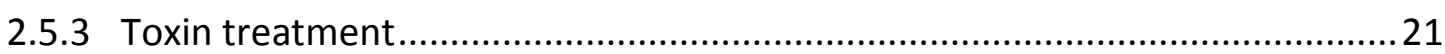

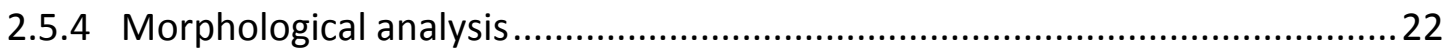

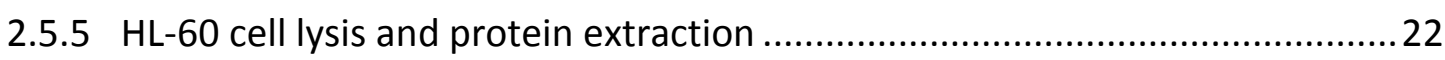

2.5.6 Preparation of samples for analysis by gel electrophoresis............................22

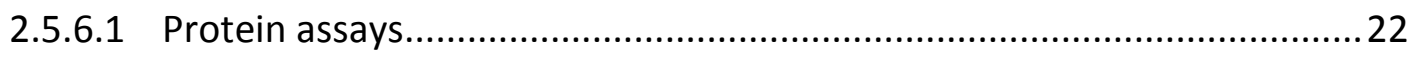

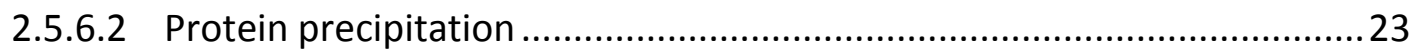

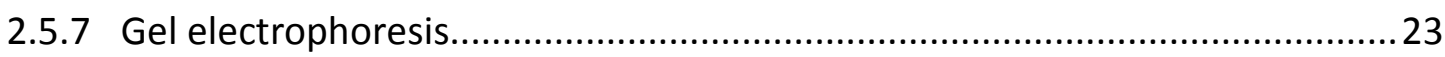

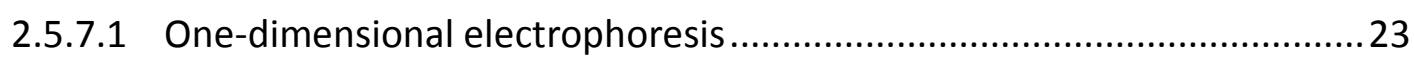

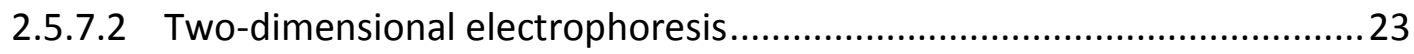

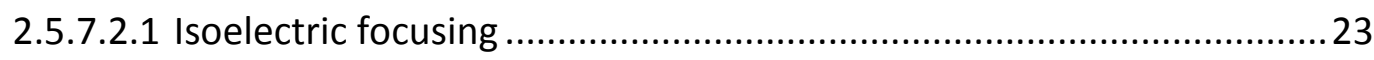

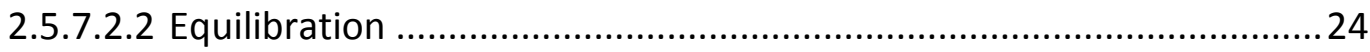

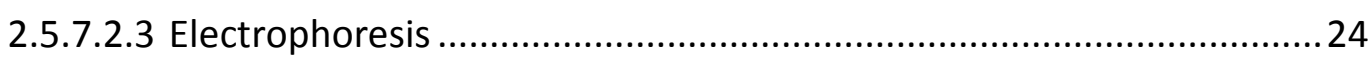

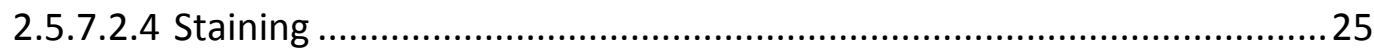

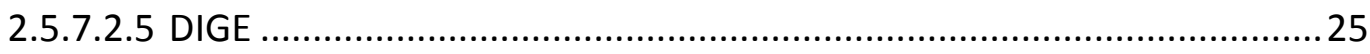

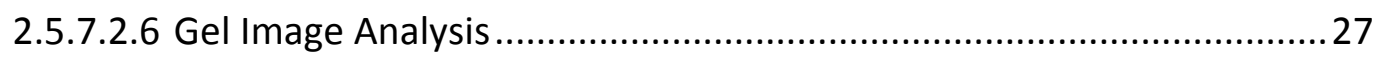

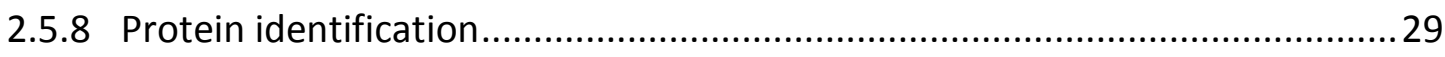

2.5.8.1 Preparation of protein spots for MALDI analysis ....................................29

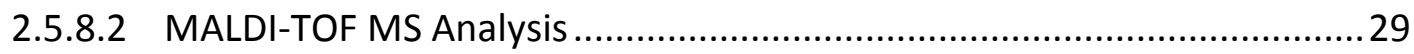

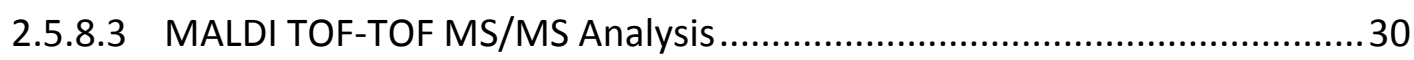

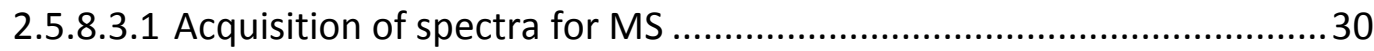

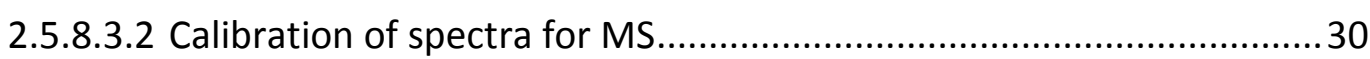

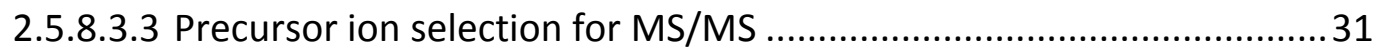

2.5.8.3.4 Acquisition of spectra for MS/MS .................................................. 31

2.5.8.3.5 Calibration of spectra for MS/MS .................................................. 31

2.5.8.3.6 Comparison of peptide sequences to NCBI database ......................... 31

3 RESULTS........................................................................ 33

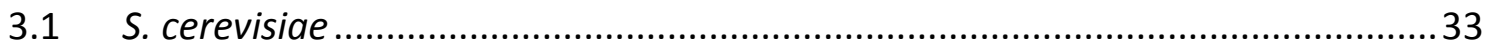

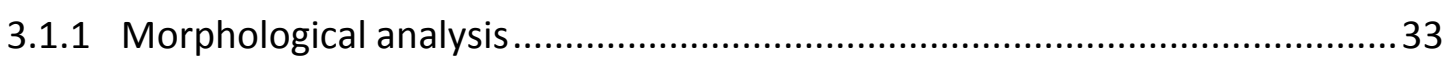

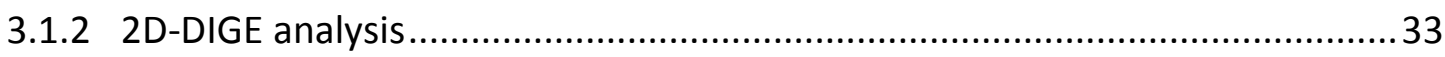


3.1.3 Protein identification by peptide mass fingerprinting .................................42

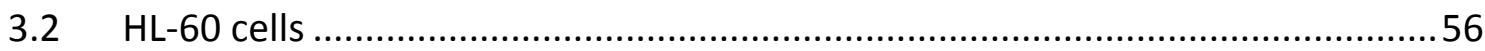

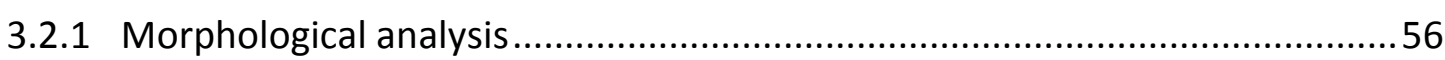

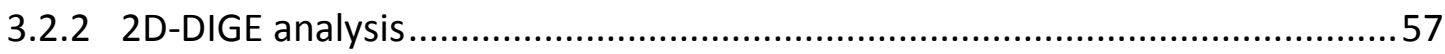

3.2.3 Protein identification by peptide mass fingerprinting ...................................62

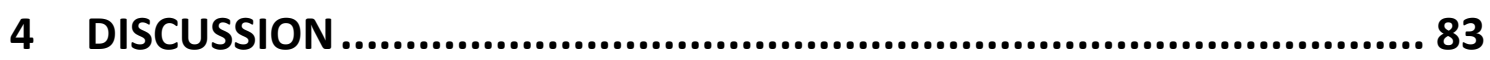

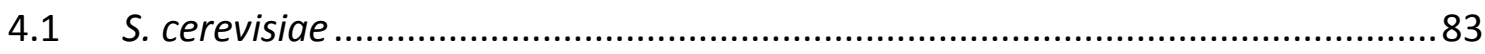

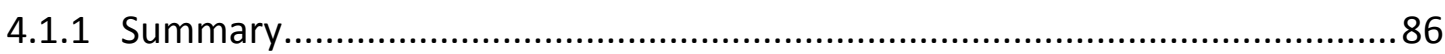

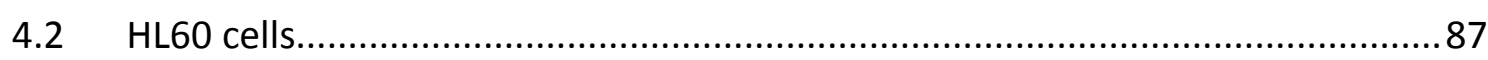

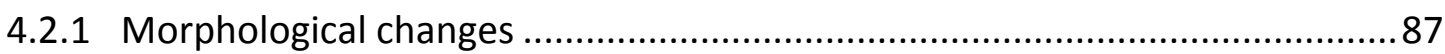

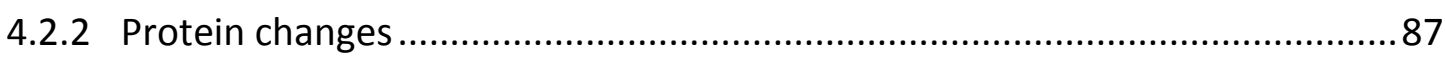

4.2.2.1 DeCyder Analysis ........................................................................... 87

4.2.2.2 Protein identifications and comparison to HepG2, Pel A, and PTX .......... 88

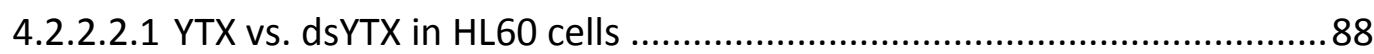

4.2.2.2.2 YTX and dsYTX in HL60 cells vs. HepG2 cells treated with YTX ............89

4.2.2.2.3 Comparison of identified protein changes in HL60 cells......................89

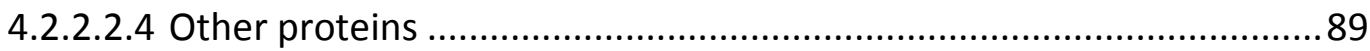

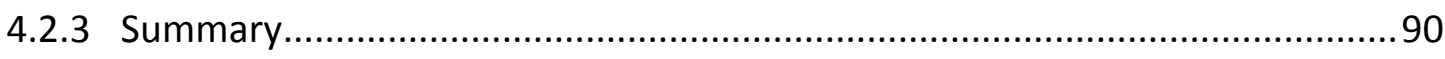

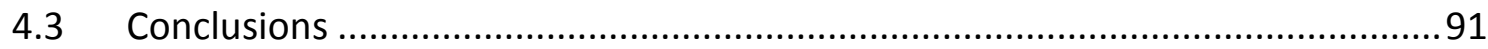

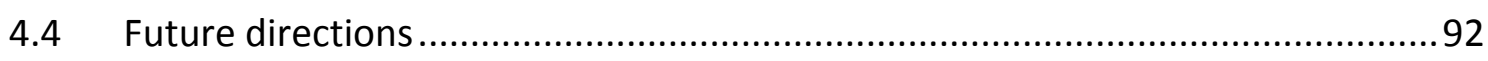

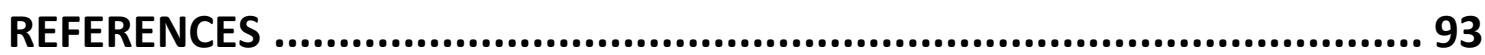

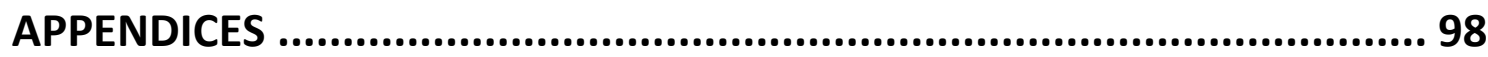

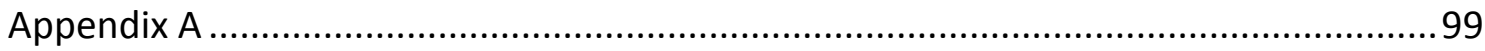

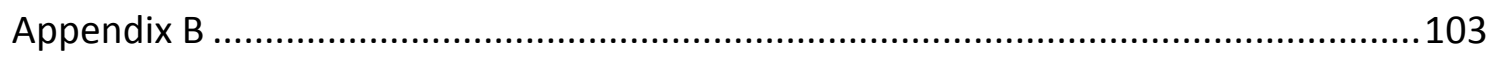

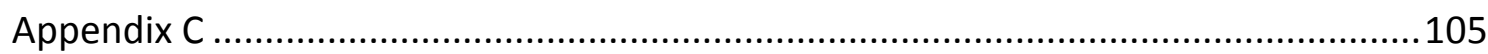

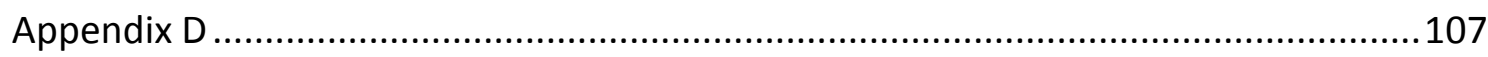

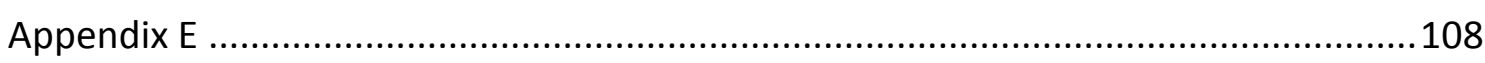

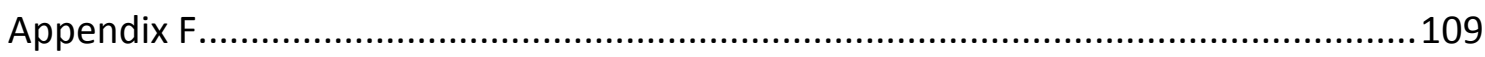

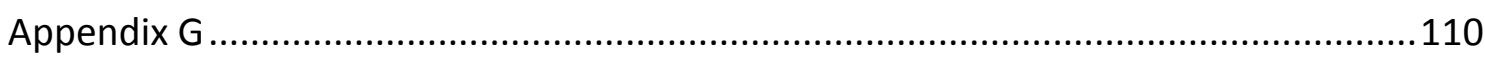

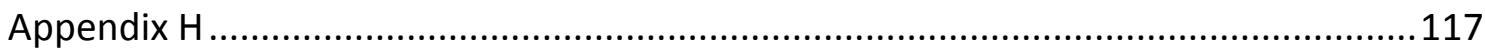

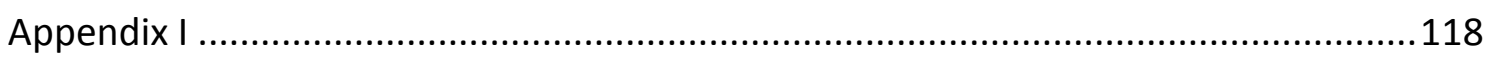

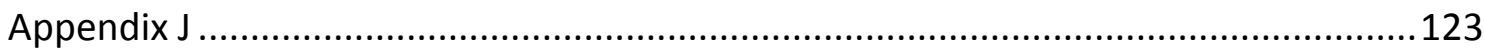




\section{LIST OF FIGURES}

Figure 1 The chemical structures of yessotoxins

Figure $\mathbf{2}$ Chemical structures of toxic polycyclic polyethers produced by dinoflagellates

Figure 3 Networks determined by IPA to be affected by YTX in HepG2 cells and Pel A in HL60 cells. 16

Figure 4 Venn diagram comparing the protein changes seen in HepG2 cells treated with YTX and HL6O cells treated with peloruside A or paclitaxel.

Figure 5 Flow diagram of DIGE procedure 26

Figure $6 \mathrm{pH}$ 4-7 and 6-11 gels of proteins extracted from stationary phase wild type yeast treated with 1.2 $\mu M$ YTX.

Figure $7 \mathrm{pH}$ 4-7 gel of proteins from stationary phase wild type yeast treated with 12 $\mu M Y T X$

Figure 8 pH 4-7 and 6-11 gels of proteins extracted from log phase wild type yeast treated with $12 \mu M$ YTX.

Figure $9 \mathrm{pH}$ 4-7 and 6-11 gels of proteins extracted from stationary phase wild type

yeast strain treated with dsYTX. 39

Figure $10 \mathrm{pH} \mathrm{4-7} \mathrm{gel} \mathrm{of} \mathrm{proteins} \mathrm{extracted} \mathrm{from} \mathrm{log} \mathrm{phase} \mathrm{AD \Delta} \mathrm{mutant} \mathrm{yeast} \mathrm{strain}$ cells, treated with $12 \mu M Y T X$

Figure $11 \mathrm{pH}$ 4-7 and 6-11 gels of proteins extracted from stationary phase mutant ADA cells, treated with dsYTX.....

Figure 12 HL6O cells in culture at 0 and $24 \mathrm{~h}$ after addition of toxin at 20x magnification

Figure 13 HL6O cells after $24 \mathrm{~h}$ incubation with dsYTX at 10x magnification. .57

Figure $14 \mathrm{Gel}$ image of protein spots of interest from HL6O cells treated with YTX or dsTYX 59

Figure 15 Distribution of protein changes detected by 2D DIGE for toxin vs. methanol when the FDR filter is not applied....

Figure 16 Distribution of protein changes detected by 2D DIGE for toxin vs. methanol when the FDR filter is applied 
Figure 17 Proteins identified as changing in HL6O cells treated with YTX or dsYTX with methanol as control, compared to changes found in HepG2 cells following $24 \mathrm{~h}$ incubation with YTX

Figure 18 Proteins identified as changing in HL6O cells treated with either YTX with methanol as control, or peloruside A or paclitaxel.

Figure 19 Proteins identified as changing in HL6O cells treated with dsYTX with methanol as control, or peloruside $A$ or paclitaxel 


\section{LIST OF TABLES}

Table $1 L D_{50}$ values by i.p injection found in mice .................................................... 5

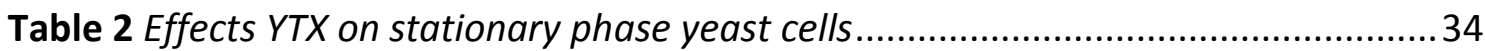

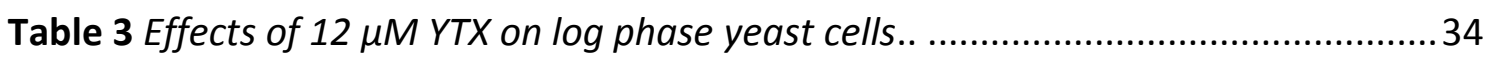

Table 4 Effects of $1.4 \mu \mathrm{M} d s Y T X$ on stationary phase yeast cells ...................................35

Table 5 Protein abundance changes in S. cerevisiae in response to YTX and dsYTX..... 44

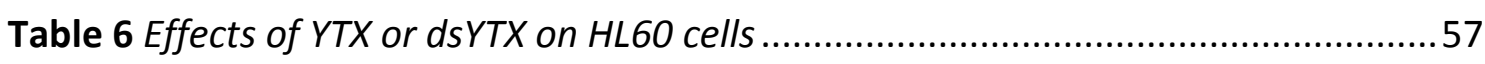

Table 7 HL60 protein DeCyder statistics and protein identifications.............................65

Table 8 HL6O DeCyder statistics and identifications of proteins identified as not

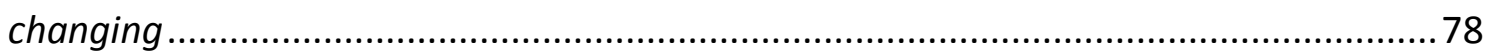




\section{INTRODUCTION}

\subsection{Yessotoxins}

Yessotoxin (YTX) is a disulfated polycyclic polyether (Fig. 1), produced by dinoflagellate algae. It was first isolated from the digestive glands of the scallops Patinopecten yessoensis collected in Japan (Murata et al., 1987). YTX was originally classed as a diarrhetic shellfish poisoning toxin (DSP) as it is often extracted with DSP toxins such as okadaic acid (OA) and dinophysistoxin (DTX) (Fig. 2). Subsequent studies have shown that it does not display any of the typical DSP characteristics, such as inducing diarrhea (Murata et al., 1987, Ogino et al., 1997) or inhibition of protein phosphatase 2A (PP2A) (Ogino et al., 1997). In 2002 a separate group was established for YTXs by the European Commission (directive 2002/225/EC). The presence of YTX in New Zealand mussels was first detected in 1997 (Yasumoto et al., 1997). The current limit of YTXs allowed in shellfish meat for human consumption is $1 \mathrm{mg}$ YTXs/kg of mollusc (Regulation (EC) No. 853/2004). The exact mechanism of action of YTX has yet to be determined.

\subsection{Algal production and shellfish metabolism}

There are currently three species of dinoflagellate algae confirmed to be producers of YTX. These are: Protoceratium reticulatum, Lingulodinium polyedrum and Gonyaulax spinifera. A phylogenetic analysis found that all YTX producing species of dinoflagellate belong to the order Gonyaulacales (Howard et al., 2009). However, there is evidence that some analogues of YTX are produced by metabolism of the toxin by the shellfish that feed on toxic algae as opposed to being produced by the algae themselves. Cultures of $P$. reticulatum have been found to contain YTX, but not 45hydroxy-YTX (45-OH-YTX), 45, 46, 47-trinor YTX or homo-YTX (Fig. 1) (Satake et al., 1997). Another study using LC-MS found indications of 93 YTXs in extracts from $P$. reticulatum (Miles et al., 2005).

In contaminated Greenshell ${ }^{\mathrm{TM}}$ mussels (Perna canaliculis) collected around the coast of the upper South Island of New Zealand in 2001, YTX was found to be the major toxin 
present. 45-OH-YTX was also detected although at a lesser concentration (Mackenzie et al., 2002). There was also evidence from liquid chromatography work, in the same study, for the presence of three other YTXs, thought to be most likely carboxy-YTX, a hydroxylated carboxy-YTX analogue and aldehyde metabolite intermediates (Fig. 1). YTX was still detectable in the shellfish meat for some time after exposure to toxic algae ended, taking approximately 100 days to decline from an initial concentration of $326 \mu \mathrm{g} / 100 \mathrm{~g}$ of shellfish meat, to the EU limit of $100 \mu \mathrm{g} / 100 \mathrm{~g}$. This gives an estimated half-life of the toxin in Greenshell ${ }^{\mathrm{TM}}$ mussels of about 49 days. Interestingly while the amount of YTXs decreased over time, the ratio of $45-\mathrm{OH}-\mathrm{YTX}$ to YTX remained constant $(12.3 \% \pm 3.3 \%)$.

A study of Norwegian Blue mussels (Mytilus edulis) (Aasen et al., 2005), found that the main toxin present was carboxy-YTX, with YTX being only a minor component, except for the time just after an algal bloom. Half-lives for the YTXs detected in the mussels were determined to be 20 days for YTX, 22 days for 45-OH-YTX, 60 days for carboxyYTX and 33 days for 46-OH-carboxy-YTX. This led to the conclusion that in Norwegian Blue mussels, YTX was converted rapidly to carboxy-YTX and, more slowly, to $45-\mathrm{OH}-$ YTX.

YTX was found to be the dominant toxin in contaminated French mussels (Mytilus galloprovincialis). The detoxification profile was similar to that of the Norwegian blue mussels (Amzil et al., 2008). Toxicology profiles from the French mussels indicated that YTX was being converted to homo-YTX as well, as this analogue had a very low initial concentration which increased during the detoxification stage.

Pacific oysters (Crassostrea gigas) were found to undergo a much faster detoxification of YTXs than mussels (M. edulis) (Roder et al., 2011). Four days after feeding on YTX producing algae ended, $C$. gigas contained only approximately $15 \%$ of the initial amount of YTX and $<5 \%$ of the initial amount of $45-\mathrm{OH}-\mathrm{YTX}$. Two mono-desulfated analogues were detected in both shellfish, one of which was found to increase during the feeding and detoxification stages, indicating that it is possibly an end product of the metabolism process. 


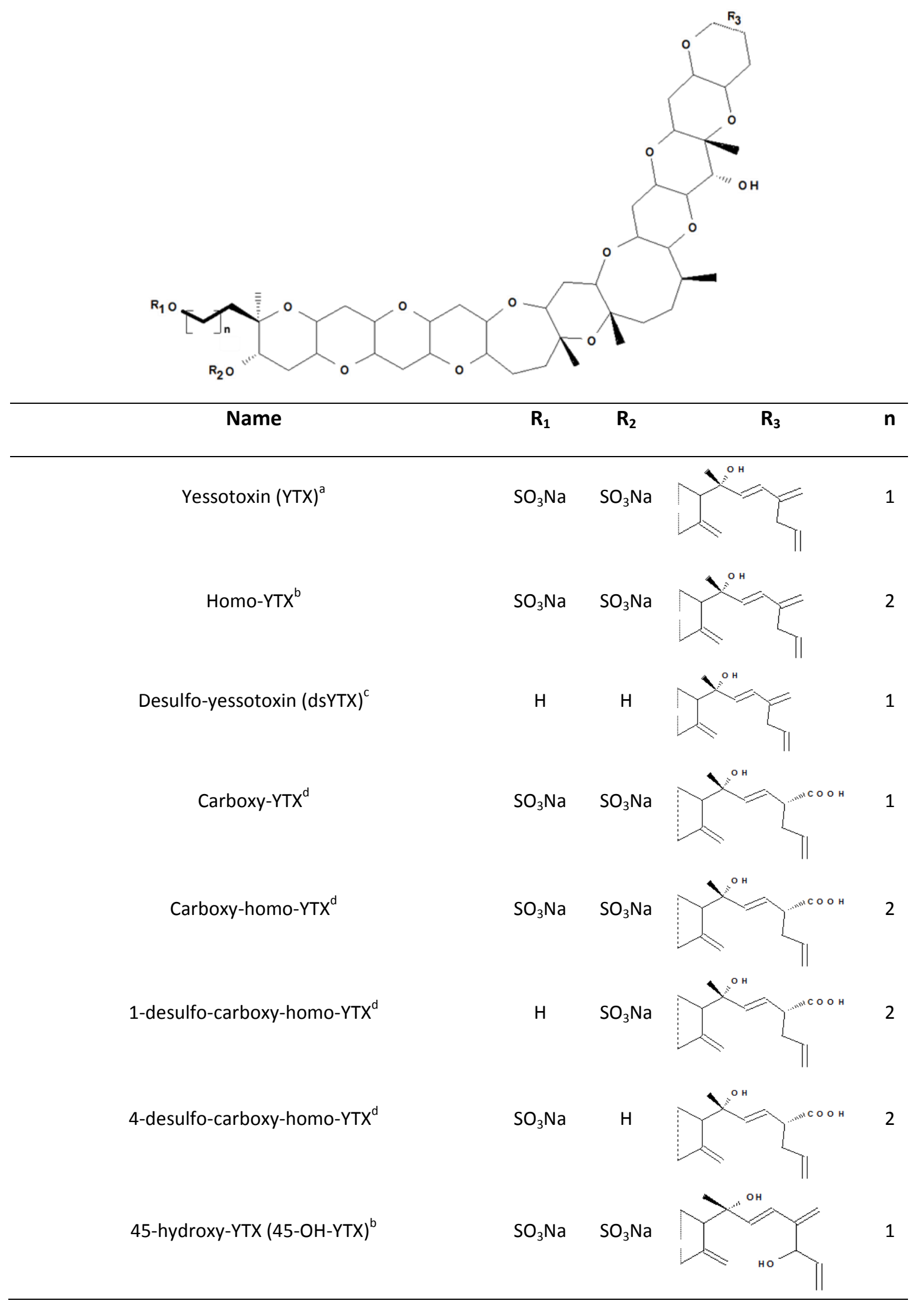

Figure 1 The chemical structure of yessotoxin (YTX), its di-desulfated derivative (dsYTX) and selected other naturally occurring derivatives.

${ }^{a}$ Young et al., 2009; ${ }^{b}$ Dominguez et al., 2010; ${ }^{c}$ Inoue et al., 2003; ${ }^{d}$ Ciminiello et al., 2007 


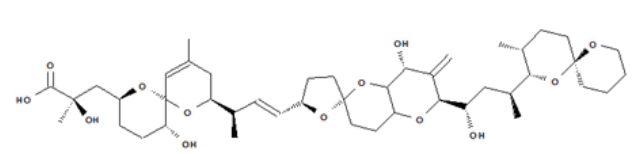

$\mathbf{A}^{1}$

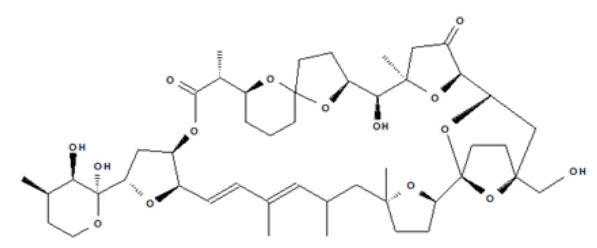

$\mathbf{C}^{1}$

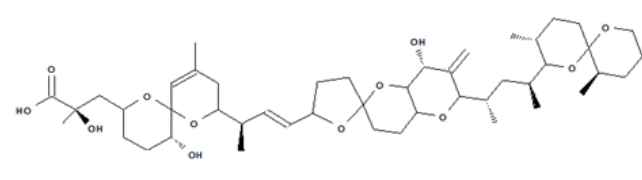

$\mathbf{E}^{3}$

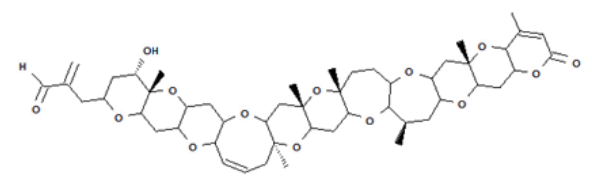

B $^{2}$

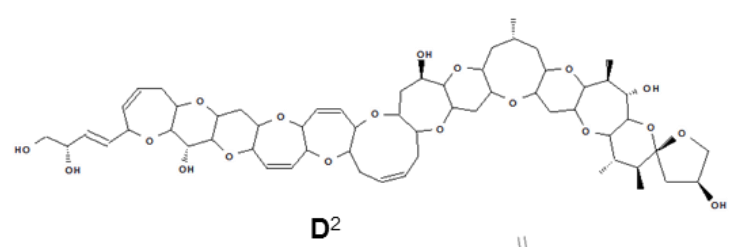

$D^{2}$
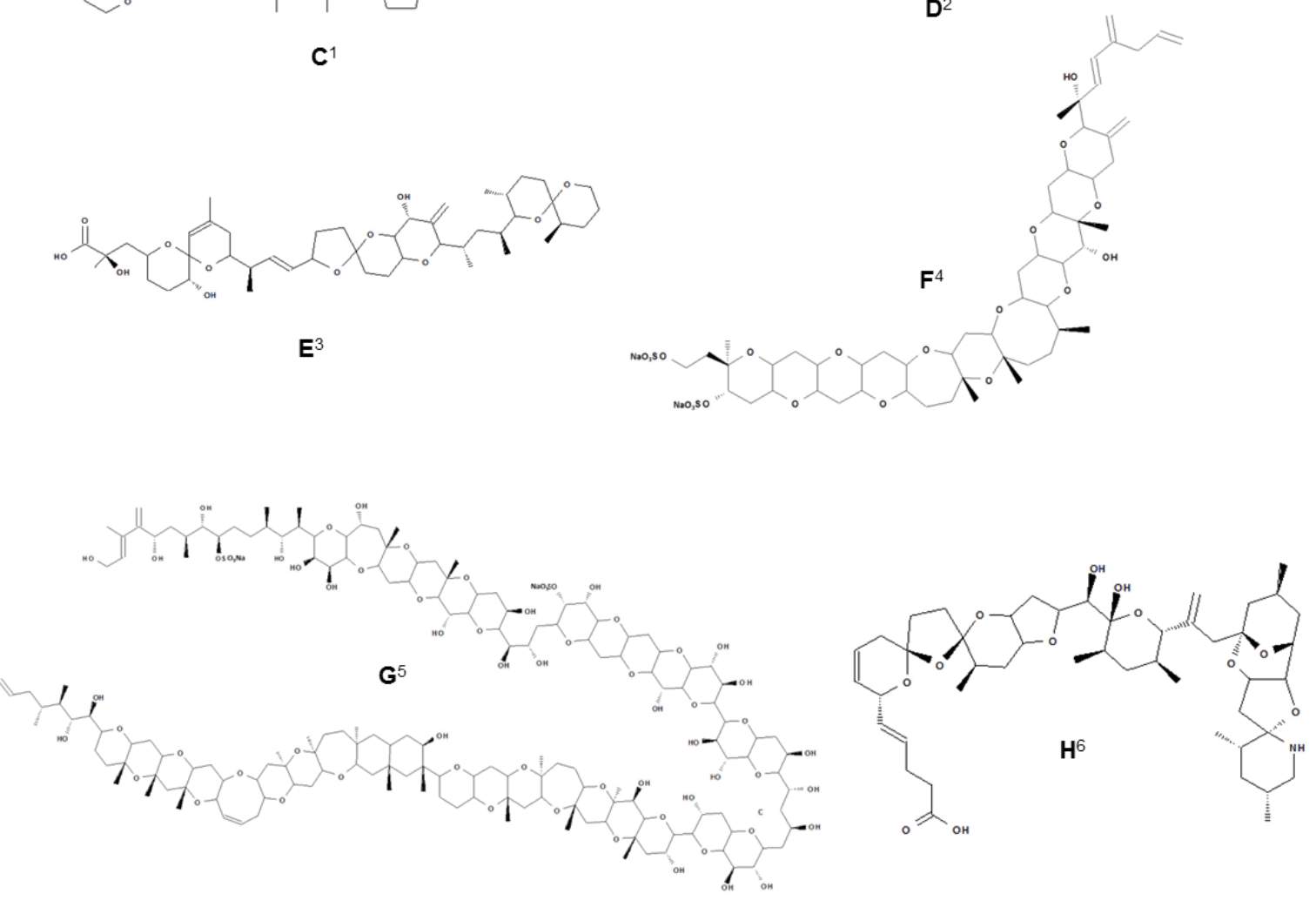

Figure 2 Chemical structures of toxic polycyclic polyethers produced by dinoflagellates. A okadaic acid (OA), B brevetoxin B, C pectenotoxin 1, D ciguatoxin, E dinophysistoxin 1 (DTX 1), F yessotoxin (YTX), G maitotoxin (MTX), H azaspiracid 1 (AZA 1)

${ }^{1}$ Dominguez et al., 2010; ${ }^{2}$ Inoue et al., 2007; ${ }^{3}$ García et al., 2005; ${ }^{4}$ Young et al., 2009; ${ }^{5}$ Nicolau et al, 2010; ${ }^{6}$ Evans et al., 2007 


\subsection{Yessotoxin}

\subsubsection{In vivo effects}

\subsubsection{Lethality}

YTX has been found to be lethal over a range of dose levels in murine studies, but only when administered by intraperitoneal (i.p) injection (Table 1). The differences in $\mathrm{LD}_{50}$ values between these studies may be due to the different strains and sexes of mice used (Aune et al., 2008). LD $\mathrm{LD}_{50}$ values may also be influenced by mice fasting or receiving food ad libitum prior to YTX treatment. Death following YTX administration appears to always occur within $24 \mathrm{~h}$ or not at all (Terao et al., 1990; Ogino et al., 1997; Aune et al., 2002; Tubaro et al., 2003; Franchini et al., 2004).

Table $1 \mathrm{LD}_{50}$ values by i.p injection found in mice. * Doses that are lethal but not necessarily an $\mathrm{LD}_{50}$

\begin{tabular}{|c|c|c|c|}
\hline Study & Strain & Sex & $\mathrm{LD}_{50}(\mu \mathrm{g} / \mathrm{kg})$ \\
\hline Murata et al., 1987 & - & - & $100^{*}$ \\
\hline Terao et al.., 1990 & IRC & $\mathrm{M}$ & 286 (at $3 \mathrm{~h}$ ) \\
\hline Ogino et al., 1997 & $d d Y$ & $\mathrm{M}$ & $80-100 *$ \\
\hline Tubaro et al., 2003 & $C D-1$ & $\mathrm{~F}$ & 512 \\
\hline \multirow[t]{6}{*}{ Aune et al., 2008} & ICR (CD-1) & $\mathrm{F}$ & 380 \\
\hline & & $M$ & 462 \\
\hline & Swiss (CFW-1) & $\mathrm{F}$ & 269 \\
\hline & & $\mathrm{M}$ & 328 \\
\hline & NMRI & $\mathrm{F}$ & 314 \\
\hline & & $M$ & 412 \\
\hline
\end{tabular}

Oral administration of YTX is non-lethal in mice, even at doses as high as $1-10 \mathrm{mg} / \mathrm{kg}$ body weight (b.w) (Ogino et al., 1997; Tubaro et al., 2003 and 2008; Aasen et al., 2011) - more than 10 times the i.p. lethal dose. This may be due to YTX being unable to cross membrane barriers and therefore being poorly absorbed following oral ingestion. 
However YTX has been detected in the blood of mice at a concentration of $3.12 \mathrm{ng} / \mathrm{mL}$, following repeated oral administration (Tubaro et al., 2008).

YTX is structurally similar to brevetoxin B (Fig. 2B) which is lethal to zebra fish (Brachydanio rerio) at a concentration of $18 \mathrm{nM}$ (Lin et al., 1981). YTX was not found to be lethal to killifish (Oryzias latipes) at a concentration of $420 \mathrm{nM}$ or $840 \mathrm{nM}$, within 24 h (Ogino et al., 1997).

\subsubsection{Symptoms}

Mice appeared to behave normally for the first hour or so following i.p administration of YTX (Terao et al., 1990). They then appeared restless, displayed jumping and muscle cramps, before dyspnea set in followed by death (Terao et al., 1990, Aune et al., 2002, Tubaro et al., 2003, Franchini et al., 2004a).

No difference in behaviour from controls was observed in mice following oral administration of YTX (Ogino et al., 1997, Aune et al., 2002, Tubaro et al., 2003)

\subsubsection{Morphological and histological analysis}

In mice, YTX appears to mainly affect the heart (Terao et al., 1990; Aune et al., 2002; Tubaro et al., 2003 and 2008), but also causes damage to the intestine and some areas of the brain (Franchini et al., 2004a and 2004b). In the heart it causes rounding and swelling of myocardial cells, rounding of the mitochondria and disrupts the organisation of myofibrils, particularly in the region around the capillaries. Little morphological or histological changes have been observed in the intestine, other than an apparent inflammation response observed in the duodenum (Franchini et al., 2004b). YTX does not cause fluid accumulation in the intestine of suckling mice (Murata et al., 1987; Ogino et al., 1997), unlike DSP toxins such as OA.

In the brain, disruption of neuron arrangement and shrinkage and increased hematoxylin and eosin staining of the cytoplasm of Purkinje cells was observed following i.p administration of a lethal dose of YTX (Franchini et al., 2004a). An increased amount of S-100 protein and a decreased amount of calbindin D-28K, both $\mathrm{Ca}^{2+}$ binding proteins, was also observed. Decreased amounts of $\beta$-tubulin, 
neurofilaments and neurotubules, and disruption to the organisation of these proteins were also detected. The authors postulated that damage to the cytoskeleton of Purkinje cells, was due to the action of increased amounts of S-100 protein. Changes to the cell organisation and an increase in the number of apoptotic cells were also seen in the thymus following i.p administration of lethal and sub-lethal doses of YTX (Franchini et al., 2004b). The same study also found an increase in the number of cells positive for the cytokines IL- 6 and TNF- $\alpha$, and a decrease in the number of IL-1 $\alpha$ AND IL-8 positive cells.

No changes (Ogino et al., 1997, Aasen et al., 2011) or changes similar to, but less pronounced than, those seen following i.p injection (Aune et al., 2002, Tubaro et al., 2008) were observed with oral administration of YTX.

\subsubsection{In vitro effects}

\subsubsection{Anti-microbial action}

YTX inhibits growth of yeast and fungi. It has no effect on bacterial growth (Ogino et al., 1997).

\subsubsection{Cell death and morphological changes}

YTX induced cell death has been observed in a range of cell types (Leira et al., 2002, Malaguti et al., 2002, Korsnes et al., 2006, Pérez-Gómez et al., 2006, Young et al., 2009, Pang et al., 2011, Korsnes et al., 2011). Changes observed accompanying cell death include DNA and chromatin fragmentation and chromatin condensation, decreased membrane potential of mitochondria, caspase activation and poly(ADPribose)polymerase (PARP) fragmentation. These changes are typically characteristic of apoptosis rather than necrosis. That YTX is inducing apoptosis is supported by Annexin V/propidium iodide (PI) staining (Leira et al., 2002, Young et al., 2009). One of the hallmarks of apoptosis is translocation of phosphatidylserine from the inner leaflet to the external surface of the cell membrane. Annexin $V$ preferentially binds to phospholipids, such as phosphatidylserine. The externalisation of phosphatidylserine 
also occurs in necrotic cells, but is also accompanied by loss of integrity of the cell membrane. The use of PI as a counterstain with Annexin $\mathrm{V}$ allows necrotic cells to be distinguished from those undergoing apoptosis using flow cytometry, as it can only enter cells with damaged membranes (Vermes et al., 1995).

Paraptosis is a form of programmed cell death which does not meet the criteria for apoptosis or necrosis (Sperandio et al., 2000). It has recently been suggested as the form of cell death induced by YTX in myoblast cells (Korsnes et al., 2011). This is due to the observation of rampant cytoplasmic vacuolisation, swelling of the ER and mitochondria, lack of DNA fragmentation and increased levels of JNK/SAPK1, which are not typically associated with apoptosis or necrosis (Korsnes et al., 2011).

Alterations to cell shape, both rounding and membrane blebbing, and detachment from adhesion surfaces were also observed (Aune et al., 1991, Leira et al., 2002, Malaguti et al., 2002, Pang et al., 2011, Korsnes et al., 2011). Effects appear to be concentration and time dependent, with higher concentrations inducing more evident damage earlier (Aune et al., 1991, Pérez-Gómez et al., 2006). The concentration of YTX required for an observable alteration in morphology also seems to depend on the type of cell used (Aune et al., 1991, Leira et al., 2002, Malaguti et al., 2002, Korsnes et al., 2006, Pérez-Gómez et al., 2006, Pang et al., 2011).

\subsubsection{Immune system}

Yessotoxin has been found to affect cells of the immune system such as macrophages (Orsi et al., 2010) and T-lymphocytes (López et al., 2011). YTX was found to inhibit macrophage maturation and their ability to internalise the yeast Candida albicans at 1 and $10 \mathrm{nM}$ concentrations but not at $0.1 \mathrm{nM}$ (Orsi et al., 2010). The same study also found changes in morphology, with macrophages becoming smaller and more rounded. The organisation of F-actin in the cytoplasm was also disrupted although no difference in the level of F-actin was detected. Production of the cytokines TNF- $\alpha$, MIP-1 $\alpha$ and MIP-2 was also found to be increased in response to YTX treatment.

In T-lymphocytes, a rapid down-regulation of the T cell receptor (TCR) followed by a late up-regulation after $48 \mathrm{~h}$ incubation with YTX is seen. YTX was able to induce this 
effect at a concentration of 1 nM (López et al., 2011). The expression of TCR returned to basal levels following removal of the toxin. This down regulatory effect was found to be partially blocked in a dose-dependent manner by staurosporine, indicating that the down-regulation of the TCR by YTX is partially modulated by the protein kinase C pathway and a second unknown pathway. The expression of other cell surface molecules such as CD90.2 and CD40L were unaffected.

\subsubsection{Effect on intra-cellular calcium}

YTX has been found to cause an increase in intracellular $\mathrm{Ca}^{2+}$ levels in human peripheral blood lymphocytes (de la Rosa et al., 2001a, b) and mussel immunocytes (Malagoli et al., 2006b). However this effect is only observed if $\mathrm{Ca}^{2+}$ is present in the extracellular matrix. Compared to maitotoxin (MTX) (Fig. 2G), another polycyclic marine toxin, YTX was not a potent inducer of $\mathrm{Ca}^{2+}$ influx (de la Rosa et al., 2001b). YTX caused intermittent influx of $\mathrm{Ca}^{2+}$ whereas MTX had a more sustained effect. MTX also affected a greater number of cells than YTX. Incubation of cells with YTX or MTX and various calcium channel blockers and agonists suggested that YTX and MTX are not acting on the same $\mathrm{Ca}^{2+}$ mediated pathway and are possibly activating more than one influx pathway (Malagoli et al., 2006a and b). YTX and dsYTX do not strongly interact with sodium channel in membranes (Inoue et al., 2003). In neuronal cells, blocking voltage sensitive calcium channels prevented calcium influx but did not stop cell death (Pérez-Gómez et al., 2006). Blocking voltage sensitive sodium channels, in the same study, also failed to prevent cell death.

The permeability transition pore (PTP) of mitochondria was also found to be affected by YTX (Bianchi et al., 2004). YTX was found to cause an increase in the rate of state 4 respiration in mitochondria isolated from rat liver. However this effect was only observed when $\mathrm{Ca}^{2+}$ was present in the media, implicating opening of the PTP. The proposed mechanism behind this effect is that $\mathrm{Ca}^{2+}$ binds to the sulphate groups of YTX at physiological pH 7.4, allowing YTX to then interact directly with the PTP or increase the hydrophobicity of YTX making it more membrane soluble. The opening of the PTP may cause activation of the mitochondrial pro-apoptotic pathway. The effect of YTX on the PTP, in addition to the increase in mitochondrial enzyme activity in 
cardiomyocytes (Dell'Ovo et al., 2008) and the mitochondrial rounding seen in vivo (Terao et al., 1990, Aune et al., 2002, Tubaro et al., 2008) suggest that mitochondria may be one of the main targets of YTX.

\subsubsection{Effect on Cyclic AMP}

Changes in the levels of intracellular CAMP have also been seen in human peripheral lymphocytes (Alfonso et al., 2003) and in primary cultures of rat cardiomyocytes (Dell'Ovo et al., 2008). In lymphocytes, YTX caused a decrease in the level of cAMP which was dependent on the presence of extracellular $\mathrm{Ca}^{2+}$ (Alfonso et al., 2003). The authors suggest that YTX is increasing the rate of CAMP hydrolysis by activating phosphodiesterases. A decrease in CAMP accumulation was also observed in rat cardiomyocytes (Dell'Ovo et al., 2008). However, this was only seen when cAMP synthesis had been stimulated by prior incubation with forskolin. YTX was not found to have any effect on basal or unstimulated levels of cAMP. A decrease in cell viability and the beat frequency of the cardiac cells was also observed. These effects are not thought to be related to the effect of YTX on CAMP as they are observed at lower concentrations than those required for a cAMP effect. A transient, but significant, increase in the activity of mitochondrial enzymes was also observed in cardiomyocytes at low concentrations (first seen at $0.1 \mathrm{nM}$ ) of YTX.

\subsubsection{Effect on the cytoskeleton}

YTX appears to cause disruption of the cytoskeleton. In MCF epithelial cells, no difference was observed in the level or structure of $\beta$ or $\gamma$-catenins, however the amount of intact E-cadherin decreased after treatment with YTX (Ronzitti et al., 2004, Callegari et al., 2006). Cell detachment was also observed. Cell growth stopped 1-2 days following treatment; however widespread cell death was not observed (Ronzitti et al., 2004). In vivo, however stabilisation of E-cadherin was observed in mouse colon, following repeated oral administration of YTX (Callegari et al., 2006). This effect appears to be reversible as no difference was detected between YTX treated and control mice 30 or 90 days after treatment. YTX did not appear to affect E-cadherin in the lungs or kidneys, or N-cadherin. YTX was found to disrupt the F-actin cytoskeleton 
within 72 hours in the IPLB-LdFB insect cell line, mouse fibroblasts and primary cultures of myoblast and cerebellar neuronal cells (Malagoli et al., 2006a, Pérez-Gómez et al., 2006, Korsnes et al., 2007). Decreased levels of native tensin and alterations to its distribution within cells were also observed (Korsnes et al., 2007). The changes caused to the cytoskeleton by YTX may account for the changes to cell morphology observed in the studies mentioned in section 1.3.3 and in in vivo studies.

\subsubsection{Proteomic studies}

Young et al. (2009) showed that the major proteins affected by YTX in HepG2 liver cells were heterogeneous nuclear ribonucleoproteins (hnRNPs), lamins, cathepsins and heat shock proteins (HSPs). Apoptosis was also observed in YTX treated cells. Ingenuity pathways analysis (IPA) provided a possible network for the interaction between the proteins affected (Fig. 3A). HnRNPs had not previously been identified as possible targets of YTX. Alterations of hnRNP levels were also seen in HL60 cells treated with the microtubule stabilising agents; Pel A or PTX (Fig. 4) (Wilmes et al., 2011, 2012). In HL60 cells treated with Pel A, IPA identified a protein network affected which was similar to that identified for YTX treated HepG2 cells (Fig. 3B).

Comparison of protein changes identified in HepG2 cells treated with YTX (Young et al., 2009) and those identified in HL60 cells in response to microtubule stabilising agents (Wilmes et al., 2011, 2012) revealed a number of proteins in common, although these were not always similarly affected (Fig. 4). BAG2, BiP (HSP70), and hnRNP A were affected in both cell lines. Lamin B1 had decreased levels in paclitaxel (PTX) treated HL60 cells and HepG2 cells treated with YTX. Actin ( $\beta$ ), $\beta$-tubulin, HSP90B1, and hnRNP $K$ were affected by Pel A in HL60 cells and YTX in HepG2 cells, although changes in abundance were usually in opposite directions. 


\subsection{Desulfo-yessotoxin}

\subsubsection{In vivo effects}

\subsubsection{Lethality}

It has been suggested that di-desulfoyessotoxin (dsYTX, Fig. 1) may be formed through metabolism of YTX by micro-organisms in the intestine of humans following ingestion (Ogino et al., 1997). Chemically prepared dsYTX, has an i.p LD Lo $_{50}$ of $301 \mu \mathrm{g} / \mathrm{kg}$ b.w at 48 $\mathrm{h}$ (Terao et al., 1990). In the same study YTX had an $\mathrm{LD}_{50}$ of $286 \mu \mathrm{g} / \mathrm{kg}$ b.w at $3 \mathrm{~h}$.

Mono-desulfated analogues, 1-desulfocarboxy-homo-YTX and 4-desulfocarboxy-homoYTX, have an i.p $L_{50}>0.5 \mathrm{mg} / \mathrm{kg}$ b.w at $24 \mathrm{~h}$, compared to YTX which was lethal to two out of three mice at a concentration of $0.1 \mathrm{mg} / \mathrm{kg}$ b.w at $24 \mathrm{~h}$ in female mice (Ciminiello et al., 2007).

dsYTX is lethal to killifish (Oryzias latipes) at a concentration of $0.5 \mathrm{ppm}(510 \mathrm{nM})$ after $6 \mathrm{~h}$ (Ogino et al., 1997). YTX was found to be non-lethal in the same study.

\subsubsection{Histopathology}

Histopathological analysis following administration of dsYTX to mice found changes in the heart, liver and pancreas, but not in the intestine (small or large), adrenal glands, kidneys, spleen or thymus (Terao et al., 1990). The main effect observed was accumulation of fat droplets within cells of the affected organs. The accumulation was slight in cardiac cells, but more pronounced in the liver, which became yellow and swollen within $12 \mathrm{~h}$ of i.p administration of $300 \mu \mathrm{g} / \mathrm{kg}$ b.w of dsYTX, and pancreatic acinar cells.

Electron microscopy of the liver cells showed approximately 1 fat droplet formed per cell, in the cytoplasm, within $10 \mathrm{~min}$ of dsYTX administration. However this increased to numerous small fat droplets within $24 \mathrm{~h}$. By $10 \mathrm{~min}$ after administration, autophagosomes were observed near the bile capillary, associated with the rough endoplasmic reticulum (ER). The cytoplasm was full of large and small autophagosomes by $24 \mathrm{~h}$. The contents of these were found to be degenerated ER, vesicles and other cell debris. At later stages after administration, autophagosomes 
were also detected in Kupffer and Ito cells. Mitochondria were also noted to be swollen and have reduced electron density (Terao et al., 1990).

The pancreatic acinar cells contained several fat droplets in their cytoplasm. Complete disappearance of zymogen granules was also observed, as well as disarrangement of the rough ER. Other pancreatic cells were not affected (Terao et al., 1990).

Lipid analysis from the same study showed that, following the administration of dsYTX, there was an increase in the total fat content of the liver, but not of the kidneys or blood. Livers of mice treated with dsYTX contained 60 times the amount of triglycerides of controls or YTX treated mice, and twice the amount of phospholipids. A lipid peroxidation assay using thiobarbituric acid, showed double the amount in dsYTX mice livers compared to YTX. This suggests the increase in fat content is due to an increased degradation of membrane structures within the cell.

Oral administration of $500 \mu \mathrm{g}$ dsYTX/kg b.w to mice $21 \mathrm{~h}$ prior to sacrifice, produced similar, but less severe, effects as i.p injection (Terao et al., 1990).

The differences in effects of dsYTX compared with the effect of YTX in vivo (section 1.3.1), indicates that the two toxins have different targets and mechanisms of action.

\subsubsection{In vitro effects}

\subsubsection{Anti-microbial action}

Like YTX, dsYTX inhibits the growth of fungi and yeast but not bacteria (Ogino et al., 1997). It was found to be a more potent inhibitor of the fungus Penicillium funiculosum than YTX, causing inhibition at $10 \mu \mathrm{g} /$ disc compared to YTX which caused inhibition at $50 \mu \mathrm{g} /$ disc.

\subsubsection{Interactions with proteins}

dsYTX has been found to enhance the hemolysis caused by alamethicin I and melittin, $\alpha$-helix containing peptides, in a dose-dependent manner (Mori et al., 2005). In the same study it was also shown to decrease the amount of oligomers of glycophorin $A$ 
and its transmembrane peptide (both containing an $\alpha$-helix), while increasing the number of dimers and monomers. This suggests that the toxin has the ability to interact with the $\alpha$-helix of these proteins and peptides. YTX and brevetoxin B (Fig. 2B) were observed to have similar efficacy as dsYTX. The tested ladder shaped polyethers (LSPs) were found to have 10-fold higher affinity than artificial polyethers in the glycophorin dissociation assay. The authors concluded that the LSP structure can generally interact with $\alpha$-helix motifs. 


\subsection{Aims}

The aims of this project were to use the proteomic techniques of differential in gel electrophoresis (DIGE) and peptide mass fingerprinting to examine the effects of YTX and dsYTX on Saccharomyces cerevisiae and HL60 cells, in order to elucidate the mechanism of action of these toxins, by identifying potential targets - either proteins or pathways.

Proteomics is the study of the proteins present in cells at a given time. Comparison of protein profiles from cells under different conditions can identify those proteins or pathways which are most affected. These may be primary targets or a secondary effect.

For this study S. cerevisiae was selected as a model organism. As many basic biological structures and processes have been preserved in eukaryotes, it is possible for yeast to serve as indicators for the function of human genes (Kolkman et al., 2005). S. cerevisiae can be readily genetically manipulated, allowing for the generation of gene knock-out mutant strains. Examining the response of a mutant strain to a compound of interest, and comparing it with the response of the wild type strain can give an indication of the target or mechanism of action of that compound.

As similarities in the proteins affected in HepG2 cells treated with YTX (Young et al., 2009) and HL60 cells treated with microtubule stabilising agents (Wilmes et al., 2011, 2012) were observed (section 1.3.2.7), HL60 cells were also exposed to YTX, in order to identify which changes seen in YTX treated HepG2 cells are toxin or cell line specific, or a general cell response to stress. 


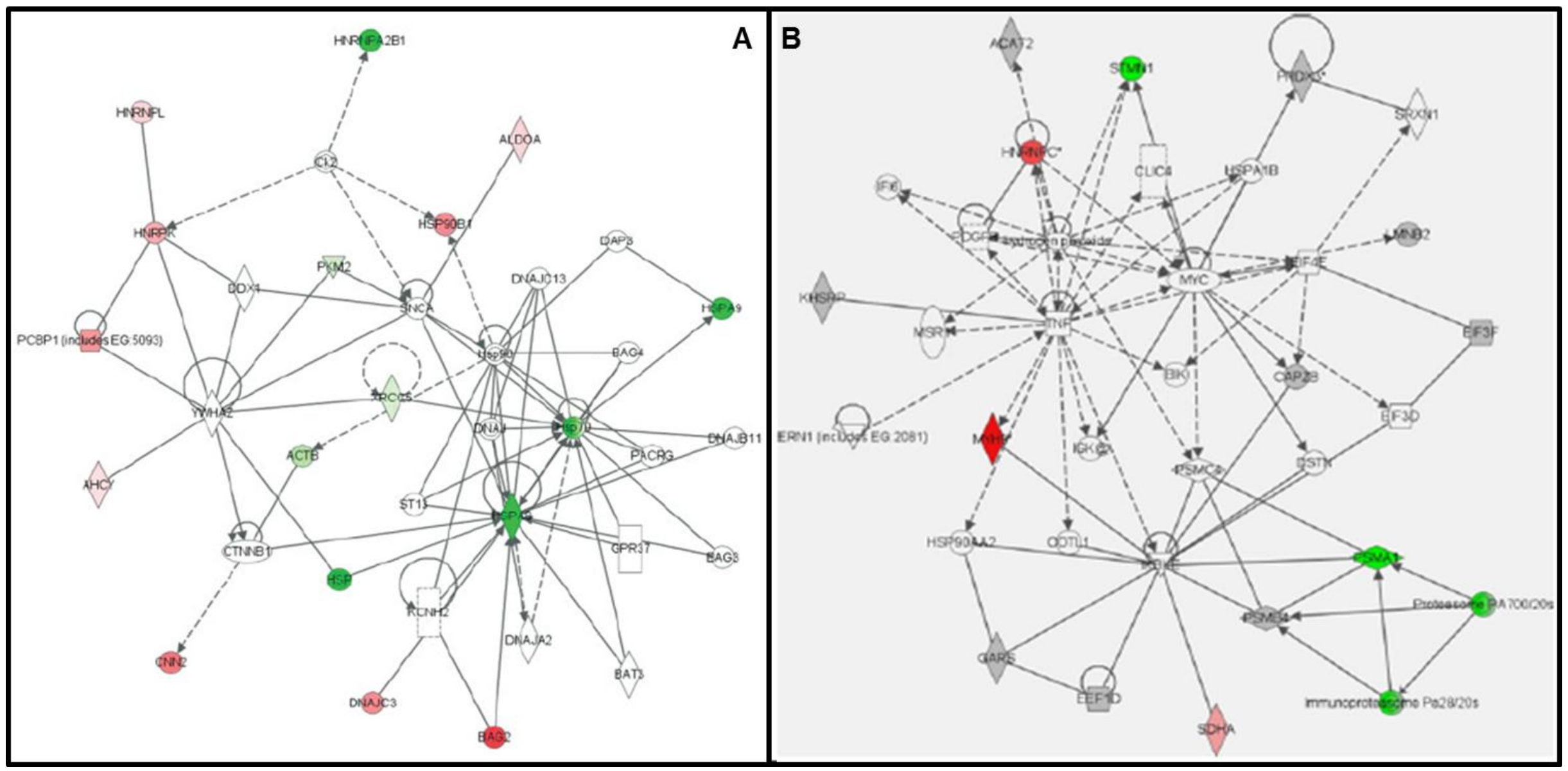

Figure 3 Networks determined by IPA to be affected by YTX in HepG2 cells (A) (Young et al., 2009) and Pel A in HL60 cells (B) (Wilmes et al., 2011). Green and red represent decreases and increases respectively in the protein abundance. The intensity of the colour reflects the magnitude of the fold change. Grey symbols are proteins that were identified but did not have a significant abundance change. Definitions of abbreviations and the symbol key are listed in Appendix A. 


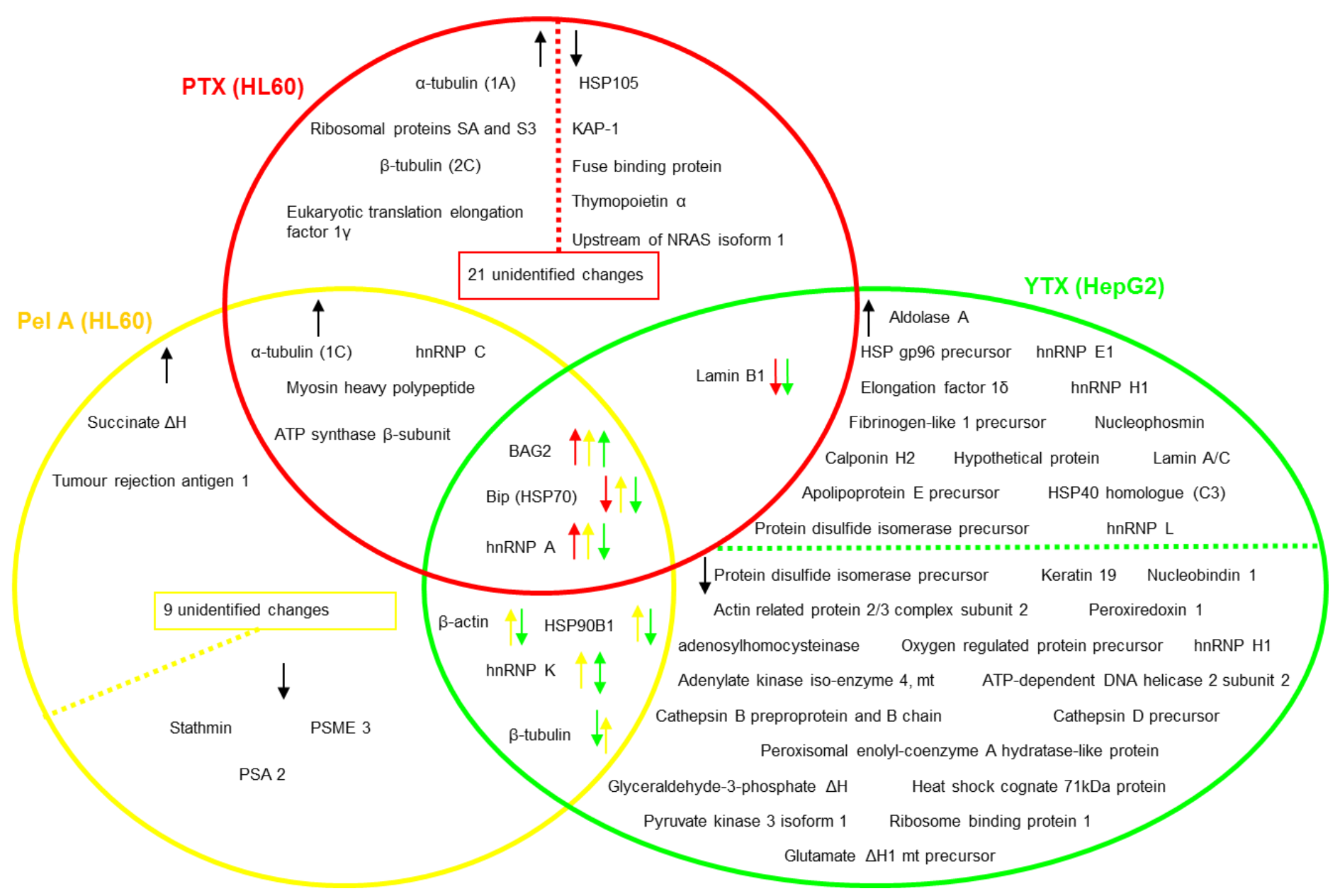

Figure 4 Venn diagram comparing the protein changes seen in HepG2 cells treated with YTX (Young et al., 2009) and HL60 cells treated with peloruside A (Pel A) or paclitaxel (PTX) (Wilmes et al., 2011, 2012). Upwards pointing arrows indicate proteins which showed an increase in abundance in response to treatment. Downwards pointing arrows indicate proteins which decreased in abundance in response to treatment. 


\section{METHODS}

\subsection{Yessotoxins}

Both YTX and dsYTX were provided by C. Miles and A.D. Hawkes, AgResearch Limited, Ruakura Research Centre, Hamilton, New Zealand. These compounds were each dissolved in methanol ( $\geq 99.8 \%$ pure), giving stock concentrations of $10 \mu \mathrm{g} / \mu \mathrm{L}$ and 5 $\mu \mathrm{g} / \mu \mathrm{L}$ respectively (Appendix B).

\subsection{Yeast strains}

The Saccharomyces cerevisiae strains used were the haploid BY4741 mat a wild type strain and an ADS pump knock-out mutant which lacks seven of the $A B C$ transporters (Lamping et al., 2007). The latter was provided by Dr. Brian C. Monk, Department of Oral Sciences, University of Otago, Dunedin, New Zealand. The ADS strain was received on agar slants. Upon arrival stocks were made up in $10 \%$ glycerol YPD media. These were stored at $-80^{\circ} \mathrm{C}$ until required.

\subsection{Mammalian cell lines}

HL-60 human promyelocytic leukemic blood leukocyte cells were used for mammalian cell work, and were acquired from Professor John H. Miller's group, School of Biological Sciences, Victoria University of Wellington, Wellington, New Zealand.

\subsection{Yeast cell culture and protein extraction}

\subsubsection{Plate culture}

S. cerevisiae strains were plated onto YPD agar plates using sterile technique. Plates were incubated at $30^{\circ} \mathrm{C}$ for 2 days. They were then stored at $4^{\circ} \mathrm{C}$ until required. 


\subsubsection{Liquid culture}

Single colonies were selected from plates and transferred into $3 \mathrm{~mL}$ of $2 \%$ glucose YPD media. These were incubated at $30^{\circ} \mathrm{C}, 225 \mathrm{rpm}$ (Bioline Shaker, Edwards Instrument Company, Australia), until cells reached stationary phase. Cultures were considered to be at stationary phase when they reached a cell density of approximately $2 \times 10^{8}$ cells/mL.

An aliquot (typically $10 \mu \mathrm{L}$ ) from these cultures was then taken and transferred into 10 $\mathrm{mL}$ of $2 \%$ glucose YPD media, and incubated until cells reached either growth or stationary phase as required. Cultures were considered to be at stationary phase when they had reached a density of approximately $2 \times 10^{8}$ cells $/ \mathrm{mL}$ or an absorbance of $0.8-1$ at $595 \mathrm{~nm}$. Cultures were considered to be at log phase when they had reached an absorbance of 0.4-0.5 at $595 \mathrm{~nm}$.

\subsubsection{Determination of cell density}

The cell density of cultures was determined by cell counting using a hemocytometer. Ten $\mu \mathrm{L}$ of a yeast sample was diluted 1:100 with Milli-Q or High-Q water, and $10 \mu \mathrm{L}$ of this was then loaded onto the hemocytometer, and observed with a phase contrast microscope

For absorbance measurements, triplicate $100 \mu \mathrm{L}$ aliquots of each sample were pipetted into a 96 well plate. Absorbance readings were measured at $595 \mathrm{~nm}$ using a Molecular Devices, VERSAmax tunable microplate reader (Applied Biosystems, Melbourne, Australia). YPD media containing $2 \%$ glucose was used as a blank.

\subsubsection{Toxin treatment}

Ten $\mathrm{mL}$ S. cerevisiae cultures were divided into $1.5 \mathrm{~mL}$ aliquots once cells had reached either log or stationary phase as required. There were three conditions tested: untreated, methanol treated, and toxin treated $(n=2)$. Two $\mu \mathrm{L}$ methanol $(0.13 \% \mathrm{v} / \mathrm{v}$ final concentration) was added to methanol treated controls. Toxin treated samples 
were treated with 2 or $20 \mu \mathrm{g}$ of YTX or $2 \mu \mathrm{g}$ of dsYTX. All cultures were then incubated at $30^{\circ} \mathrm{C}$ for $24 \mathrm{~h}$.

S. cerevisiae cells from liquid cultures were harvested by centrifugation at $2300 \mathrm{~g}$ for 5 min. The supernatants were discarded and the pellets were resuspended in $1.5 \mathrm{~mL}$ Milli-Q or High-Q water before being centrifuged as before. The supernatants were removed and the wash step repeated. The supernatants were removed and the pellets were resuspended in $1 \mathrm{~mL}$ protease inhibitor solution (1 complete mini EDTA free protease inhibitor cocktail tablet (Catalogue number: 11836170 001, Roche Diagnostics $\mathrm{GmbH}$, Mannheim, Germany) dissolved in $10 \mathrm{~mL}$ Milli-Q or High-Q water). The cell suspensions were then centrifuged as before, the supernatants were removed and cell pellets were stored at $-80^{\circ} \mathrm{C}$ until required.

\subsubsection{Morphological analysis}

Ten $\mu \mathrm{L}$ of sample culture was diluted 1:100 with Milli-Q or High-Q distilled water. Fifty $\mu \mathrm{L}$ of the diluted sample was then observed using a phase contrast microscope.

\subsubsection{Cell lysis and protein extraction}

Cell pellets were resuspended in $100 \mu \mathrm{L}$ cell lysis buffer (30 mM TrisCl (pH 8.8), $7 \mathrm{M}$ urea, $2 \mathrm{M}$ thiourea, $4 \% \mathrm{w} / \mathrm{v}$ CHAPS) and transferred to $1.5 \mathrm{~mL}$ microcentrifuge tubes containing approximately $50 \mu \mathrm{L}$ white quartz sand (50+70 mesh, SIGMA-ALDRICH Inc., St. Louis, Missouri). The samples were then ground using mini pestles. During this process the samples were kept on ice. Following grinding, the samples were vortexed for $30 \mathrm{~min}$ at $4^{\circ} \mathrm{C}$. They were then centrifuged at $16,000 \mathrm{~g}$ for $15 \mathrm{~min}$ at $4^{\circ} \mathrm{C}$. The supernatants were transferred to $0.6 \mathrm{~mL}$ microcentrifuge tubes and stored at $-20^{\circ} \mathrm{C}$ until required. On average, $1 \times 10^{7}$ cells yielded approximately $20 \mu \mathrm{g}$ of protein. 


\subsection{HL-60 cell culture and protein extraction}

\subsubsection{Mammalian cell culture}

$\mathrm{HL}-60$ cells were cultured in $\mathrm{GIBCO}^{\circledR}$ RPMI-1640 media containing L-glutamine and phenol red indicator (Invitrogen). The media was supplemented with 10\% FCS, 100 units $/ \mathrm{mL}$ penicillin and 100 units $/ \mathrm{mL}$ streptomycin, at $37^{\circ} \mathrm{C}$ with $5 \% \mathrm{CO}_{2}$ in air. When cells reached approximately $80 \%$ confluency they were passaged by diluting the culture $1: 10$ or $1: 20$ with media.

\subsubsection{Determination of cell density}

The density of HL-60 cells was determined by a trypan blue live/dead exclusion assay. Ten $\mu \mathrm{L}$ of HL-60 cell samples were diluted $1: 2$ with $0.4 \%$ trypan blue. Ten $\mu \mathrm{L}$ of this was then loaded onto a hemocytometer. Live cells were considered to be those which were white or colourless. Cells which displayed blue colouration were considered to be dead. Only live cells were considered when calculating cell density.

\subsubsection{Toxin treatment}

Three $\times 20 \mathrm{~mL}$ cultures of HL-60 cells were grown to $80 \%$ confluency then combined, and $9 \times 10^{6}$ cells were then seeded into cultures of $10 \mathrm{~mL}$ total volume. Ten $\mathrm{mL}$ cultures $(n=4)$ were then treated with methanol $(0.02 \% \mathrm{v} / \mathrm{v}$ final concentration) or 1 $\mu \mathrm{M}$ of YTX or dsYTX. The cultures were then incubated at $37^{\circ} \mathrm{C}$ with $5 \% \mathrm{CO}_{2}$ in air for $24 \mathrm{~h}$.

HL-60 replicates were then transferred to $15 \mathrm{~mL}$ screw top test tubes and centrifuged at $300 \mathrm{~g}$ for $5 \mathrm{~min}$. The supernatants were discarded and the pellets were resuspended in $10 \mathrm{~mL}$ ice cold PBS before being centrifuged as before. The supernatants were removed and discarded. The pellets were resuspended in $1 \mathrm{~mL}$ of PBS and transferred to $1.5 \mathrm{~mL}$ microcentrifuge tubes and centrifuged at $300 \mathrm{rpm}$ (SIGMA 1-14 Laboratory Table Top Microcentrifuge). The supernatants were discarded 
and the pellets resuspended in $1 \mathrm{~mL}$ PBS/protease inhibitor solution (one complete mini EDTA free protease inhibitor cocktail tablet (Catalogue number: 11836170001 , Roche) in $10 \mathrm{~mL}$ PBS and centrifuged again. The supernatant was removed from each sample as much as possible. The pellets were then stored at $-80^{\circ} \mathrm{C}$ until required.

\subsubsection{Morphological analysis}

HL60 cells were observed in culture using phase contrast microscopy.

Images of cells were acquired using a CC12 Soft Imaging System camera connected to an Olympus IX51 microscope, and Olympus Cell A Imaging software.

\subsubsection{HL-60 cell lysis and protein extraction}

Lysis buffer was added to pellets in a ratio of $60 \mu \mathrm{L}$ per $3.6 \times 10^{6}$ cells. The pellets were resuspended in lysis buffer and vortexed for $30 \mathrm{~min}$ at $4^{\circ} \mathrm{C}$. They were then centrifuged at $16,000 \mathrm{~g}$ for $15 \mathrm{~min}$ at $4^{\circ} \mathrm{C}$. The supernatants were then transferred to $0.6 \mathrm{~mL}$ microcentrifuge tubes and stored at $-20^{\circ} \mathrm{C}$ until required. On average, approximately $960 \mu \mathrm{g}$ of protein were extracted per $1 \times 10^{7}$ cells.

\subsubsection{Preparation of samples for analysis by gel electrophoresis}

\subsubsection{Protein assays}

Triplicate $1 \mu \mathrm{L}$ aliquots from each yeast or HL-60 sample were pipetted into a 96 well plate. Two hundred $\mu \mathrm{L}$ of Protein Assay, Dye Reagent concentrate (Bio-Rad, Hercules, California) diluted with 4 volume equivalents of Milli-Q or High-Q water was then added to each well. Absorbance readings were measured at $595 \mathrm{~nm}$ using a Molecular Devices, VERSAmax tunable microplate reader (Applied Biosystems). The protein concentration of samples was determined by comparison to a BSA standard curve. 


\subsubsection{Protein precipitation}

Proteins were precipitated using Calbiochem ProteoExtract ${ }^{\mathrm{TM}}$ Protein precipitation kit (Merck, Darmstadt, Germany). One hundred $\mu \mathrm{L}$ of precipitant was added to 50-100 $\mu \mathrm{L}$ protein extracts from yeast samples. For HL-60 protein extracts $4 \times$ volume equivalents of precipitant were added. The samples were then incubated at $-20^{\circ} \mathrm{C}$ for at least $1 \mathrm{~h}$. Following this they were centrifuged at $13,000 \mathrm{~g}$ for $10 \mathrm{~min}$. The supernatants were discarded and $100 \mu \mathrm{L}$ of wash buffer was added to each pellet. The samples were vortexed briefly, before being centrifuged at $13,000 \mathrm{~g}$ for $5 \mathrm{~min}$. The supernatants were removed again and the wash step repeated. The pellets were then allowed to dry at room temperature for $30 \mathrm{~min}$ before being resuspended in either lysis buffer or rehydration buffer.

\subsubsection{Gel electrophoresis}

\subsubsection{One-dimensional electrophoresis}

Stock sample buffer was made up consisting of $2.5 \mu \mathrm{L}$ LDS sample buffer (4x, NuPAGE ${ }^{\circledR}$, Invitrogen, Carlsbad, California), $1 \mu$ L reducing agent (10x, NuPAGE ${ }^{\circledR}$, Invitrogen) and $5.5 \mu \mathrm{L}$ Milli-Q or High-Q water per sample). One $\mu \mathrm{L}$ of sample was added to $9 \mu \mathrm{L}$ of sample buffer solution. The samples were then vortexed and centrifuged briefly to remove air bubbles. The samples were electrophoresed on 4-12\% Bis-Tris gels (NuPAGE ${ }^{\circledR}$, Invitrogen), at 200V, $400 \mathrm{~mA}$ for $55 \mathrm{~min}$, in MOPS running buffer (MOPS SDS running buffer (20x) NuPAGE ${ }^{\circledR}$, Invitrogen). The buffer in the central chamber had $500 \mu \mathrm{L}$ of antioxidant (Invitrogen) added before electrophoresis began.

\subsubsection{Two-dimensional electrophoresis}

\subsection{Isoelectric focusing}

Protein samples were separated by IEF on $7 \mathrm{~cm}$ Immoboline ${ }^{\mathrm{TM}}$ DryStrips (GE Healthcare Bio-Sciences A.B, Uppsala, Sweden). Following the precipitation procedure pellets were resuspended in either $125 \mu \mathrm{L}$ of rehydration buffer $(2 \mathrm{M}$ thiourea, $7 \mathrm{M}$ urea, $2 \%$ DTT, 4\% CHAPS, trace bromophenol blue, 2\% IPG buffer (GE Healthcare)), for samples 
to be focused on $\mathrm{pH} 3-10, \mathrm{pH}$ 3-10 NL or $\mathrm{pH}$ 4-7 DryStrips, or $100 \mu \mathrm{L}$ rehydration buffer (2 $\mathrm{M}$ thiourea, $7 \mathrm{M}$ urea, 2.5\% DTT, 2\% CHAPS, 5\% glycerol, 10\% isopropanol, 1\% IPG buffer) for samples to be focused on pH 6-11 DryStrips. Samples focused on pH 3-10, pH 3-10 NL or pH 4-7 DryStrips were loaded onto the strips by passive loading. This was done by rehydrating the strip overnight in $125 \mu \mathrm{L}$ of sample containing rehydration buffer. The $\mathrm{pH}$ 6-11 DryStrips always had samples loaded onto them by cup-loading, so were rehydrated overnight in $125 \mu \mathrm{L}$ of rehydration buffer. Rehydration of DryStrips was done in an Immobiline DryStrip Reswelling tray (GE Healthcare). After being placed into rehydration buffer each strip was covered with 3 $\mathrm{mL}$ of mineral oil (PlusOne DryStrip cover fluid, GE Healthcare).

IEF was carried out using a Multiphor II system (Pharmacia) connected to a power supply (electrophoresis power supply EPS $3500 \mathrm{XL}$, Pharmacia BioTech) and waterbath (Julabo). DryStrips were run on gradient setting. The first step was at $200 \mathrm{~V}$ for $1 \mathrm{~h}$. The second step was $3500 \mathrm{~V}$ for $1 \mathrm{~h} 30 \mathrm{~min}$. The last step was at $3500 \mathrm{~V}$ for $1 \mathrm{~h} 30 \mathrm{~min}$ for $\mathrm{pH}$ 3-10, and 4-7 strips; and $1 \mathrm{~h} 5 \mathrm{~min}$ for $\mathrm{pH} \mathrm{6-11} \mathrm{and} \mathrm{3-10} \mathrm{NL} \mathrm{strips.} \mathrm{Temperature}$ was kept constant at $20^{\circ} \mathrm{C}$. Total current was $2 \mathrm{~mA}$ and total power was $5 \mathrm{~W}$. Strips were either equilibrated immediately following IEF, prior to loading on second dimension gels or stored at $-80^{\circ} \mathrm{C}$ until required.

\subsection{Equilibration}

Strips were equilibrated by $2 \times 10$ min incubations in 2-2.5 mL equilibration buffer (50 $\mathrm{mM}$ Tris- $\mathrm{HCl}(\mathrm{pH} 8.8), 6 \mathrm{M}$ urea, $30 \% \mathrm{v} / \mathrm{v}$ glycerol, $2 \% \mathrm{w} / \mathrm{v}$ SDS). The first $10 \mathrm{~min}$ incubation was in $1 \%$ DTT equilibration buffer, the second in $2.5 \%$ IAA equilibration buffer.

\subsection{Electrophoresis}

Second dimension SDS-PAGE was carried out under the same conditions as for 1DE gels on $4-12 \%$ Bis-Tris ZOOM ${ }^{\mathrm{TM}}$ gels (NuPAGE ${ }^{\circledR}$, Invitrogen). 


\subsection{Staining}

Gels were stained with Coomassie Brilliant Blue G-250 powder (Bio-Rad). The gels were incubated for at least $30 \mathrm{~min}$ in fixing solution (50\% ethanol, $3 \%$ phosphoric acid) before being washed for $3 \times 30$ min with Milli-Q or High-Q water. Gels were then incubated in staining solution (34\% methanol, $17 \%$ ammonium sulphate, $3 \%$ phosphoric acid) for at least an hour. A small spatula tip (approximately $10 \mathrm{mg}$ ) of Coomassie was added and the gels were left to stain for at least 3 days at room temperature. Gels were washed thoroughly with Milli-Q or High-Q water, at least $3 x$ 30 min incubations, to remove excess Coomassie prior to image acquisition using a Molecular Dynamics Personal Densitometer SI.

\subsection{DIGE}

DIGE is proteomics tool which allows direct comparison of samples across multiple gels. Protein samples are labelled with one of three CyDye fluorophores (fluors): Cy2, Cy3 or Cy5. The CyDyes bind to lysine residues present in the proteins. The CyDye fluors are positively charged, to replace the charge on the lysine when bound, so the isoelectric point of the protein is not affected. The CyDyes are also weight matched to each other, so identical proteins will migrate the same distance regardless of which dye they are labelled with. Each CyDye has a different excitation frequency. This allows multiple samples (two) to be run on one gel, alongside an internal standard. An internal standard is a pool of all the samples in a given experiment, and is run on all gels in the experiment. This aids protein spot matching between gels, reducing the effect of gel to gel variation. An overview of the DIGE procedure is shown in fig. 5 .

In this project, protein samples were minimally labelled with CyDye fluors. Minimal labelling results in 1-2\% of lysine residues being bound by CyDyes (in theory one fluor is bound per protein). This gives a linear relationship between fluorescence and protein concentration, allowing accurate comparison of protein abundances to be made. 

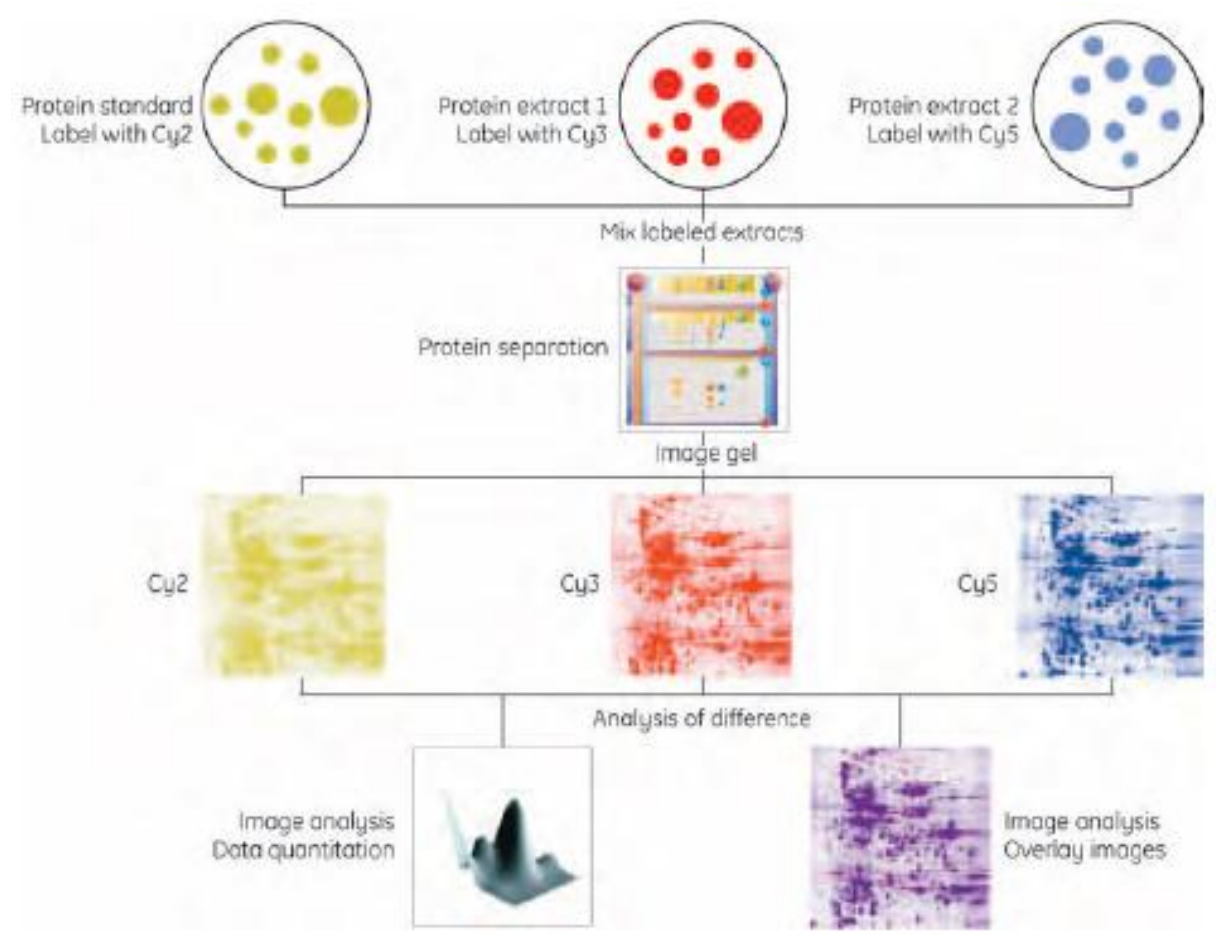

Figure 5 Flow diagram of DIGE procedure. Proteins were separated by 2DE. Image analysis and quantitation was carried out using DeCyder software version 6.5. (Image source: 2-D Electrophoresis: Principles and Methods handbook, GE Healthcare)

The protein concentration of a sample was adjusted to lie in the range $5-10 \mu \mathrm{g} / \mu \mathrm{L}$ by precipitating the protein, as previously described, and then resuspending the sample in suitable volume of lysis buffer.

The $\mathrm{pH}$ of the samples was adjusted to 8.5 by the addition of a small amount (0.1-0.5 $\mu \mathrm{L})$ of $\mathrm{pH}$ 8.8 Tris-HCl buffer.

Eighty pmol of Cy3 or Cy5 CyDyes (GE Healthcare) were added to $20 \mu \mathrm{g}$ of protein from each treatment condition. Half of the replicates from each condition were labelled with Cy3 and the other half were labelled with Cy5. An internal standard was made consisting of $10 \mu \mathrm{g}$ of protein from each sample, and $240 \mathrm{pmol}$ of Cy2. The samples were vortexed and centrifuged briefly before being incubated on ice for $30 \mathrm{~min}$ in the dark. One $\mu \mathrm{L}$ of $10 \mathrm{mM}$ lysine per $20 \mu \mathrm{g}$ of protein was added to each solution to quench the reaction. The samples were vortexed and centrifuged briefly, then incubated on ice for a further $15 \mathrm{~min}$ in the dark. The samples were then combined so 
that sample mixtures contained equal amounts of internal standard, and samples from two different treatment conditions. If not analysed straight away mixed sample solutions were stored in the dark at $-20^{\circ} \mathrm{C}$. An example of a DIGE experiment design is shown in Appendix C.

Samples underwent first and second dimension separation as described previously. Immediately after second dimension separation had been completed, 2D-DIGE gels were scanned using a Fujifilm Fluorescent Image Analyser FLA-5100 scanner (Fuji Photo Film Co. Ltd., Tokyo, Japan). Cy2 images were scanned using a $473 \mathrm{~nm}$ laser and BPB1/530DF20 filter. Cy3 images were scanned using a $532 \mathrm{~nm}$ laser and BPG1/570DF20 filter. Cy5 images were scanned using a $635 \mathrm{~nm}$ laser and DBR1/R665 filter. All gels were scanned at $50 \mu \mathrm{m}$ resolution and 16 bits.

\subsection{Gel Image Analysis}

DIGE gel images were acquired as TIFF files from the scanner. These were converted to .gel files using IQ Tools software, version 5.2 (Molecular Dynamics). The .gel files were then combined to make one multichannel image using Fluorochrome Separation 2.2, Multicolour version (Molecular Dynamics) to make the dataset file. The intensity of each CyDye signal was adjusted using IQ Tools, until it was approximately even between all gels, and protein spots were visible on the display. The image was then cropped, before being imported into DeCyder 2D Software, version 6.5 (GE Healthcare) for DIGE analysis.

The images from one experiment were all imported into DeCyder using the Image Loader function. They were then all processed simultaneously using the Batch Processor function. Estimated number of spots for spot detection was set to 2500 . The Batch Processor detects and matches the spots on multiple gels automatically. All gels are matched to a master gel (by default the gel assigned as the master is one on which the most protein spots are detected). Matching is based on a pattern recognition algorithm, where a spot on one gel is matched to a spot on another gel based on the surrounding spots. This process has two parts to it. The first part matches large spots over the whole gel, by comparing the positions and sizes of the spots around it. These matched spots are then used as landmarks. The remaining 
spots are matched, moving outwards from the landmarked spots. The second part of the spot matching process involves transforming the spot centre detected on one gel to another gel. The transformation is considered a match if the transformed coordinates are close enough to the spot centre detected on the other gel. After each matching step the algorithm performs a control which removes obvious mismatches.

Following batch processing, the created workspace was opened in the DeCyder Biological Variation Analysis (BVA) module. The spot matching was checked and corrected manually if required. BVA was used to calculate changes in spot volume (average ratio) and statistics for the change (Student's $t$-test, one way ANOVA). Proteins were labelled as being of interest if they had a $t$-test value $\leq 0.05$ and an average ratio value $\leq-1.5$ or $\geq 1.5$. Changes in protein abundance of 2 -fold or greater ( $p \leq 0.01$ ) were considered significant. Two biological replicates per treatment group were used for initial exploratory experiments. Four biological replicates per treatment group were used in the final experiment to give a power of 0.8 (Karp and Lilley, 2007).

To determine if spots of interest were true protein spots or just noise, possibly from dust, spots were also inspected in the 3D-view in DeCyder. Sharp peaks, generally around the edge of a gel, were classed as noise. Round peaks were classed as protein spots (Appendix D). The false discovery rate (FDR) filter was used to control for type I errors. Applying this filter identifies protein spots that have a change in abundance which is more likely to have arisen through chance, than to be a true effect of the treatment.

The average ratio was calculated from the log standardised abundance of the protein spots. The degree of difference in the standardised abundance was the average ratio. The average ratio is expressed as values from $-\infty$ to -1 or 1 to $\infty$. The abundance of a protein spot was quantified as a function of the internal standard. This value is the standardised abundance. The $\log _{10}$ of this was the log standardised abundance. 


\subsubsection{Protein identification}

Proteins were identified by peptide mass fingerprinting. Proteins were excised from 2D gels then subjected to tryptic digestion. The resultant peptide fragments were then subjected to MALDI analysis either on a Voyager-DE PRO mass spectrometer or an $A B$ Sciex TOF/TOF 5800 mass spectrometer. The sequences acquired from this process were then searched against the NCBI non-redundant protein sequence database using either the Profound or Mascot algorithm.

\subsubsection{Preparation of protein spots for MALDI analysis}

Protein spots were extracted from the gels using a spot picker (OneTouch Plus Spot/Band picker PDM1.5, The Gel Company, San Francisco, California) or a scalpel and placed in a 96 well v-bottom plate containing $100 \mu \mathrm{L}$ destaining solution $(50 \%$ methanol, $50 \mathrm{mM}$ ammonium bicarbonate) in each well. The plate was then left to destain overnight at $4^{\circ} \mathrm{C}$. The plates were then processed using an Ettan Automatic Digester (Amersham Biosciences) with the following programme: 3 cycles in 50\% methanol, $50 \mathrm{mM}$ ammonium bicarbonate for 20 min each, followed by air drying for $60 \mathrm{~min}$. Trypsin (Modified Sequencing Grade, Roche); (0.05 $\mathrm{\mu g} /$ well in $20 \mathrm{mM}$ ammonium bicarbonate) was added for $300 \mathrm{~min}$, followed by the addition of $20 \mathrm{mM}$ ammonium bicarbonate for $\mathbf{2 0} \mathrm{min}$. The peptides were transferred to a fresh plate by adding a solution of $50 \%$ acetonitrile and $0.1 \%$ TFA for $3 \times 20$ min cycles. The recovered proteins were allowed to air dry overnight in a laminar flow hood. Once dry, the proteins were resuspended in $1.5 \mu \mathrm{L}$ of $\mathrm{CHCA}$ matrix $(10 \mathrm{mg} / \mathrm{mL} \mathrm{CHCA}, 0.25 \%$ TFA, $50 \%$ acetonitrile, containing $0.5 \mu \mathrm{L}$ of Calibration Mixture 2 (AB Sciex, Foster City, California)). Resuspended samples were transferred onto a MALDI plate and left to dry overnight.

\subsubsection{MALDI-TOF MS Analysis}

MALDI TOF analysis was carried out using a Voyager-DE PRO mass spectrometer (Applied Biosystems). The spectra were collected over the mass range $500-3500 \mathrm{~m} / \mathrm{z}$, with an approximate laser intensity range of 1450-1600 and 100 shots were collected per spectrum. Analysis of the spectra was carried out using Data Explorer software version 5.1 (Applied Biosystems). The acquired spectra were calibrated internally 
using Calibration Mixture 2 (Applied Biosystems, Foster City, CA) ), containing a angiotensin I (average m/z 1297.51), adrenocorticotropic hormone (ACTH) clip 1-17 (average $\mathrm{m} / \mathrm{z}$ 2093.0867) and ACTH clip 18-39 (average m/z 2465.1989). Trypsin peaks ( $\mathrm{m} / \mathrm{z}$ 805.4167, 1153.5740, 2163.0566) were also used for internal calibration if they were present in the spectrum. The peptide masses generated were then searched against the NCBI non-redundant database (2009/09/01) for S. cerevisiae using the Profound algorithm. Search criteria included a protein mass in the range of 0-300 kDa, one missed trypsin cleavage, complete cysteine modification by IAA and partial modification of methionine by oxidation, and a mass tolerance of $40 \mathrm{ppm}$. Match criteria included at least 5 matched peptides, sequence coverage (correct cleavage sites - peptides end with $K$ or $R, \geq 20 \%$ coverage), and a difference between first and second ranked identifications of at least $1 \times 10^{-3}$.

\subsubsection{MALDI TOF-TOF MS/MS Analysis}

MALDI TOF-TOF MS/MS analysis of samples was carried out using an AB Sciex TOF/TOF 5800 mass spectrometer (Applied Biosystems, Foster City, CA) equipped with a diode pulse laser $(355 \mathrm{~nm}, 1 \mathrm{kHz})$. The spectrometer was controlled by TOF/TOF ${ }^{\mathrm{TM}}$ Series Explorer ${ }^{\mathrm{TM}}$ Software.

\subsection{Acquisition of spectra for MS}

Spectra for MS analysis were acquired in positive reflector mode with CID off. Peptide fragments were collected in the mass range 800-4000 Da. The laser intensity was fixed at 3000 with a pulse rate of $400 \mathrm{~Hz}$. The laser was fired in a uniform random pattern. A total of 400 laser shots were collected per full spectrum.

\subsection{Calibration of spectra for MS}

MS spectra were internally calibrated using CalMix2 (Applied Biosystems) monoisotopic peaks for angiotensin I ( $\mathrm{m} / \mathrm{z}$ 1296.6853), adrenocorticotropic hormone (ACTH) clip 1-17 (m/z 2093.0867), ACTH clip 18-39 (m/z 2465.1989) and ACTH clip 7-38 ( $\mathrm{m} / \mathrm{z}$ 3657.9294). Peak matching criteria for calibration included a signal to noise ratio greater than or equal to 5 , mass tolerance of $\pm 0.3 \mathrm{~m} / \mathrm{z}$, a minimum of 3 matched 
peaks, and maximum outlier error was $0.8 \mathrm{~m} / \mathrm{z}$. A list of reference masses is shown in Appendix E.

\subsection{Precursor ion selection for MS/MS}

Selection criteria for precursors to undergo MS/MS analysis included a signal to noise ratio greater than or equal to 20 , mass within the range $800-4000 \mathrm{Da}$, and exclusion of precursor ions within a resolution of 200 of the selected precursor ion. Known adduct, calibration and common contaminant peaks, such as trypsin, were excluded. A full list of exclusion masses is shown in Appendix F. A maximum of 10 precursor ions were selected per spot. MS/MS data were acquired from weakest precursor ion first.

\subsection{Acquisition of spectra for MS/MS}

Spectra for MS/MS analysis were acquired in $1 \mathrm{kV}$ positive reflector mode, with CID and metastable suppressor on. The laser intensity was fixed at 3500 with a pulse rate of $1000 \mathrm{~Hz}$. The laser was fired in a random uniform pattern. Acquisition of spectra was stopped after 5 sub-spectra were collected. A total of 1000 laser shots were collected for the final spectrum.

\subsection{Calibration of spectra for MS/MS}

The monoisotopic angiotensin 1 peak (1296.800 Da) was the selected precursor ion for calibration. MS/MS spectra were then calibrated using known fragment ion masses from this precursor ion (Appendix D). Peak matching criteria for calibration included a signal to noise ratio greater than or equal to 10 , mass tolerance of $\pm 0.3 \mathrm{~m} / \mathrm{z}$, a minimum of 3 matched peaks, and maximum outlier error of $20 \mathrm{ppm}$.

\subsection{Comparison of peptide sequences to NCBI database}

Peptide fingerprints and MS/MS sequences were imported into Protein Pilot ${ }^{\mathrm{TM}}$ software. The MASCOT algorithm was used to search the generated peaks lists against the NCBI non-redundant database (2008/09/02, 21331 sequences) for S. cerevisiae (905409 sequences) for proteins obtained from S. cerevisiae samples, or for Homo sapiens (218446 sequences) for proteins from HL-60 cells. Other search parameters included one missed trypsin cleavage, fixed carbamidomethyl modification of cysteine 
by IAA, variable modification by methionine oxidation, MS/MS fragment tolerance of $\pm 0.1 \mathrm{Da}$, precursor tolerance of $\pm 0.05 \mathrm{Da}$, monoisotopic masses, and a +1 peptide charge. 


\section{RESULTS}

\subsection{S. cerevisiae}

The effects of YTX and dsYTX were initially examined using 2D DIGE. The goal was to identify proteins that changed for comparison with known effects of YTX on HepG2 cells (Young et al., 2009). MALDI mass fingerprinting was used to identify protein spots excised from 2D gels.

\subsubsection{Morphological analysis}

The morphology of $S$. cerevisiae samples was observed at $0 \mathrm{~h}$ and $24 \mathrm{~h}$ after toxin treatment, using phase contrast microscopy. There were no differences in morphology between toxin treated cells and controls in either the wild type or pump knock-out mutant strain.

\subsubsection{D-DIGE analysis}

The protein extracts from preliminary tests on yeast $(n=2)$ in stationary and log phase, wild type and pump knock-out mutant yeast strains, treated with either $1.2 \mu \mathrm{M}$ or 12 $\mu \mathrm{M}$ YTX or $1.4 \mu \mathrm{M}$ dsYTX were analysed for changes in levels of protein expression by 2D DIGE. The gel images were analysed using DeCyder software (version 6.5), which quantified the fold change and calculated the relevant statistics. A change in protein abundance $\geq 2$-fold, $p \leq 0.01$ was considered significant (Karp et al., 2007). However, as very few protein spots matched this criterion, the decision was made to also take note of proteins which might be changing below the defined significance level. The criteria for these proteins of interest was a fold change $\geq 1.5, p \leq 0.05$. Tables $2-4$ summarise the number of protein spots of interest detected under each experimental condition. These changes were only observed when the false detection rate (FDR) filter was not applied. When the FDR filter was applied, no protein spots met the criteria for significance. DeCyder statistics for all proteins of interest and picked protein spots are reported on the Supplementary Data on CD. 
Table 2 Effects of YTX on stationary phase yeast cells. The number of proteins from stationary phase BY4741 and AD $\triangle$ strains, which showed a change in possible change in abundance when analysed using DIGE ( $\geq 1.5$-fold, $p \leq 0.05$ ). No protein changes were significant using the criteria $\geq 2$-fold, $p \leq 0.01$. The total spots detected per gel, includes all data point matches detected by DeCyder software, including those which are not necessarily protein spots.

\begin{tabular}{|c|c|c|c|c|c|c|c|c|c|}
\hline \multicolumn{2}{|c|}{ Stationary phase } & \multicolumn{8}{|c|}{ Comparison of Change } \\
\hline \multirow{2}{*}{ Strain } & \multirow{2}{*}{$\mathrm{pH}$} & \multicolumn{2}{|c|}{ YTX/untreated } & \multicolumn{2}{|c|}{ YTX/MeOH } & \multicolumn{2}{|c|}{ MeOH/untreated } & \multicolumn{2}{|c|}{ Total spots } \\
\hline & & $1.2 \mu \mathrm{M}$ & $12 \mu \mathrm{M}$ & $1.2 \mu \mathrm{M}$ & $12 \mu \mathrm{M}$ & $1.2 \mu \mathrm{M}$ & $12 \mu \mathrm{M}$ & $1.2 \mu \mathrm{M}$ & $12 \mu \mathrm{M}$ \\
\hline \multirow{2}{*}{ BY4741 } & $4-7$ & 2 & 0 & 1 & 6 & 0 & 0 & 2530 & 2355 \\
\hline & $6-11$ & 1 & 0 & 0 & 0 & 0 & 0 & 2565 & 2318 \\
\hline \multirow{2}{*}{ AD $\Delta$} & $4-7$ & 0 & 0 & 0 & 0 & 0 & 0 & 2062 & 2330 \\
\hline & $6-11$ & 0 & 0 & 0 & 0 & 0 & 0 & 2458 & 2564 \\
\hline
\end{tabular}

All detected changes in response to $1.2 \mu \mathrm{M}$ YTX were decreases in protein abundance (Table 5, Figs 6 and 7). The two proteins that showed a change in YTX treated cells compared to untreated controls, did not show a change when compared to methanol treated controls. The six detected changes in cells treated with $12 \mu \mathrm{M}$ YTX compared to methanol controls were split equally between increasing and decreasing abundances. However no changes in abundance were seen when proteins from treated cells were compared to those from untreated control cells.

Table 3 Effects of $12 \mu \mathrm{M}$ YTX on log phase yeast cells. The number of proteins from log phase yeast cells, BY4741 and ADA strains, which were deemed to be of interest when comparing the different experimental treatments ( $\geq 1.5$-fold, $p \leq 0.05$ ). No protein changes were significant using the criteria $\geq$ 2 -fold, $p \leq 0.01$. The total spots detected per gel, includes all data point matches detected by DeCyder software, including those which are not necessarily protein spots.

\begin{tabular}{|c|c|c|c|c|c|}
\hline \multicolumn{2}{|c|}{ Log phase } & \multicolumn{5}{c|}{ Comparison of Change } \\
\hline \multirow{2}{*}{ Strain } & pH & YTX/untreated & YTX/MeOH & MeOH/untreated & Total spots \\
\hline \multirow{2}{*}{ BY4741 } & $4-7$ & 6 & 0 & 6 & 2361 \\
\cline { 2 - 6 } & $6-11$ & 6 & 0 & 7 & 2514 \\
\hline \multirow{2}{*}{ AD $\Delta$} & $4-7$ & 3 & 6 & 0 & 2324 \\
\cline { 2 - 6 } & $6-11$ & 0 & 0 & 0 & 2294 \\
\hline
\end{tabular}


Of the six protein spots identified as changing in the $\mathrm{pH}$ 4-7 log phase wild type strain cells in response to YTX (Table 3, Fig. 8), four were also detected as changing between controls. In the pH 6-11 gels, two of the six identified as changing were also detected changing between controls. All three of the protein spots identified as undergoing a change in ADS cells in response to YTX compared with untreated cells, were also changing when compared to methanol treated cells (Table 3, Fig. 10).

Table 4 Effects of $1.4 \mu \mathrm{M}$ dsYTX on stationary phase yeast cells. Proteins from log phase yeast cells, from BY4741 and AD $\Delta$ strains, which were deemed to be of interest when comparing the different experimental treatments. Numbers not in brackets are the total number of spots which showed a possible change in abundance ( $\geq 1.5$-fold, $p \leq 0.05$ ). The number in brackets is the total number of these spots which showed a significant change in abundance ( $\geq 2$-fold, $p \leq 0.01)$. The total spots detected per gel, includes all data point matches detected by DeCyder software, including those which are not necessarily protein spots.

\begin{tabular}{|c|c|c|c|c|c|}
\hline \multicolumn{2}{|c|}{$\begin{array}{c}\text { Stationary + } \\
\text { dsYTX }\end{array}$} & \multicolumn{4}{c|}{ Comparison of Change } \\
\hline Strain & pH & dsYTX/untreated & dsYTX/MeOH & MeOH/untreated & Total spots \\
\hline \multirow{2}{*}{ BY4741 } & $4-7$ & $6(1)$ & $7(0)$ & 0 & 2254 \\
\cline { 2 - 6 } & $6-11$ & $1(1)$ & $3(0)$ & 0 & 2475 \\
\hline \multirow{2}{*}{ ADD } & $4-7$ & $8(2)$ & $26(2)$ & 0 & 2403 \\
\cline { 2 - 6 } & $6-11$ & $2(0)$ & $5(0)$ & 0 & 2200 \\
\hline
\end{tabular}

Four of the six protein spots identified as undergoing a change in abundance in response to dsYTX ( $\mathrm{pH} \mathrm{4-7)} \mathrm{when} \mathrm{compared} \mathrm{to} \mathrm{untreated} \mathrm{cells} \mathrm{in} \mathrm{wild} \mathrm{type} \mathrm{BY4741}$ cells, also changed when compared to methanol treated controls (Table 4, Fig. 9). The protein spot detected as possibly changing on $\mathrm{pH} \mathrm{6-11} \mathrm{gels} \mathrm{in} \mathrm{response} \mathrm{to} \mathrm{dsYTX} \mathrm{also}$ changed when compared to methanol treated cells. The effect of dsYTX appeared to be similar between wild type and pump mutant strains, although it was possibly greater in AD $\Delta$ cells, with more protein spots showing a detectable change in abundance. For AD $\Delta$ cells six of the eight detected in $\mathrm{pH} \mathrm{4-7,} \mathrm{and} \mathrm{both} \mathrm{of} \mathrm{the} \mathrm{protein}$ spots detected in $\mathrm{pH}$ 6-11 gel images, changed when compared with methanol treated cells as well (Table 4, Fig. 11). 


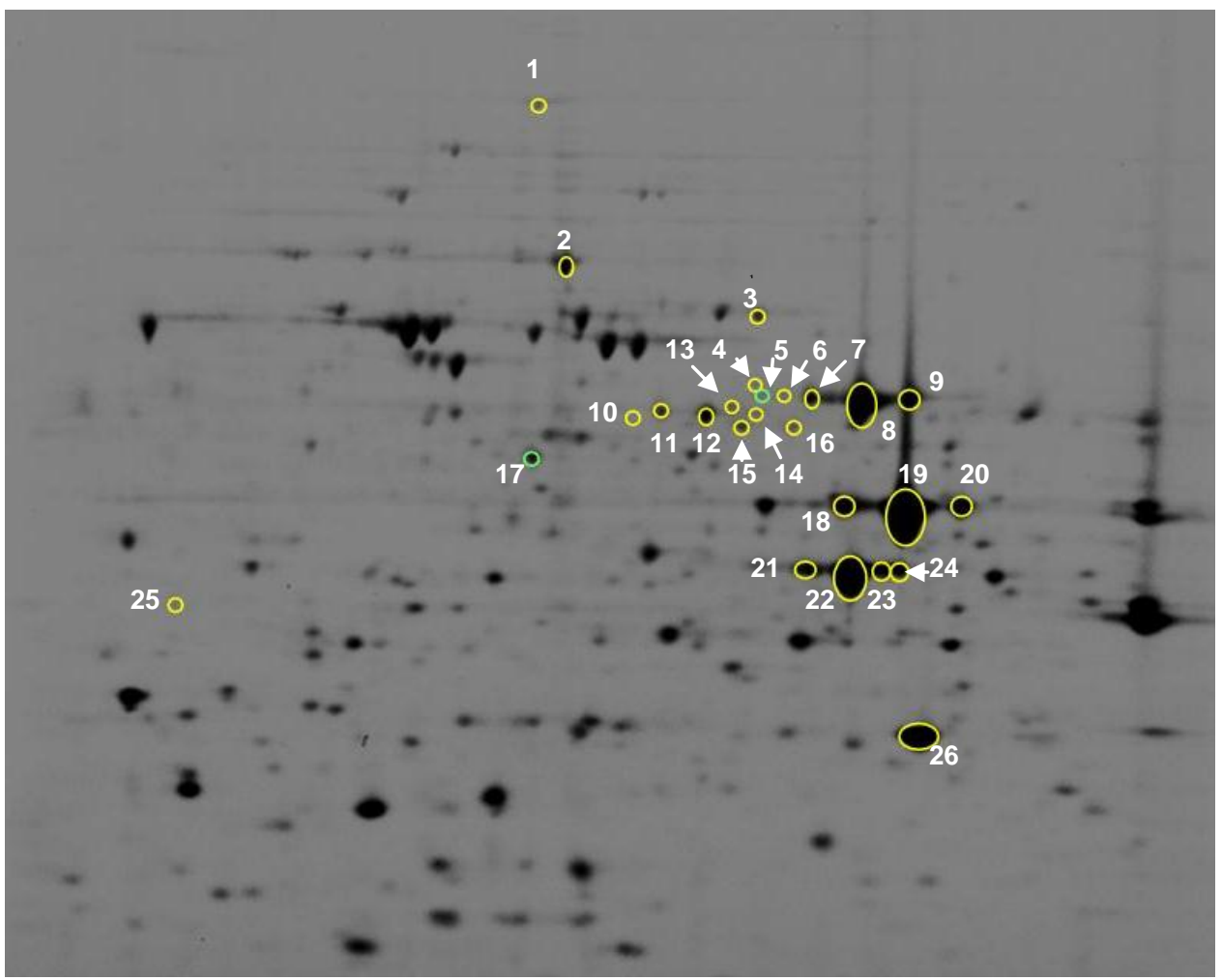

4

7

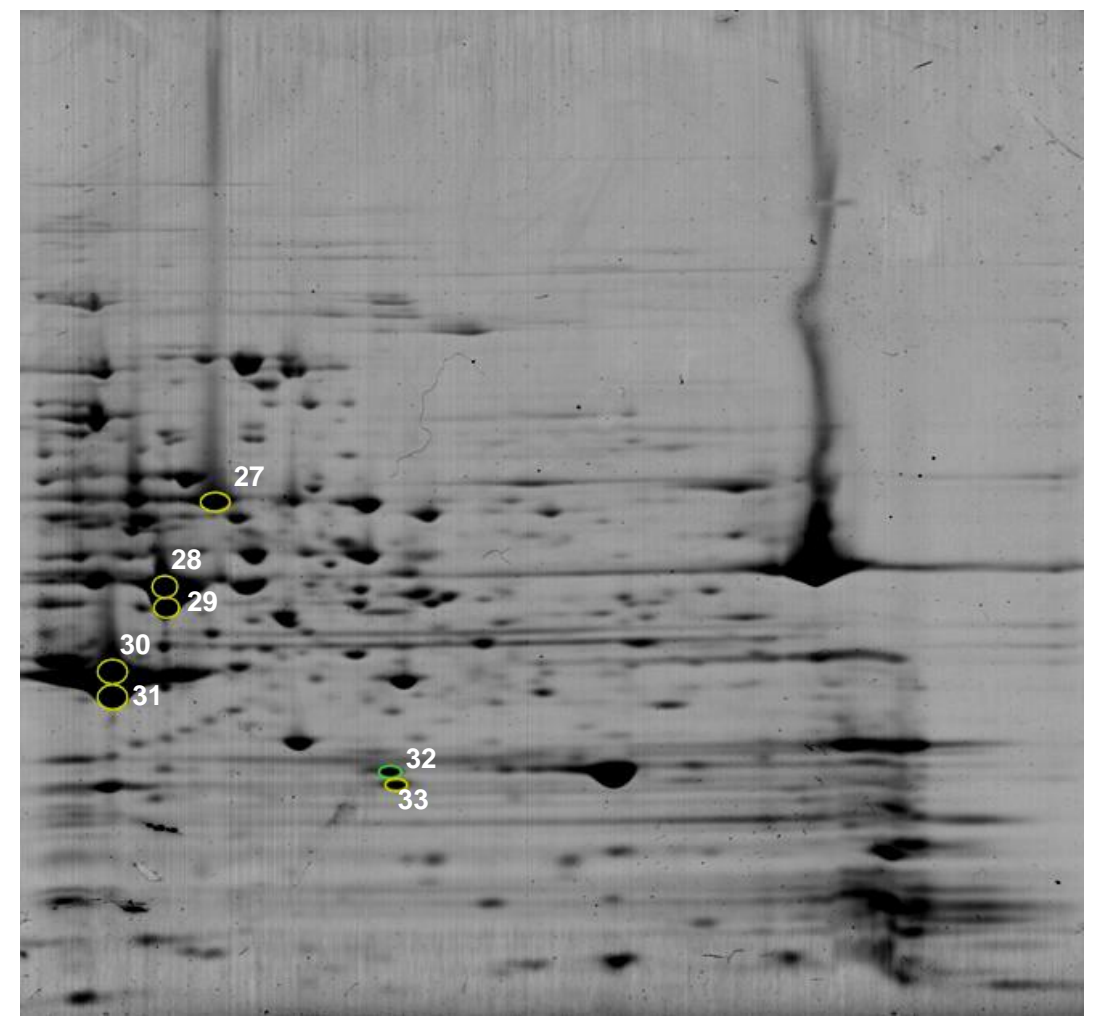

11

Figure 6 Coomassie blue stained gels, $\mathrm{pH}$ 4-7 and 6-11, of proteins extracted from stationary phase wild type yeast cells treated with $1.2 \mu \mathrm{M}$ YTX for $24 \mathrm{~h}$. Yellow $=$ not changing. Pale green $=$ tending towards a decreasing abundance but not significant (fold change $\geq 1.5, p \leq 0.05$ ). 


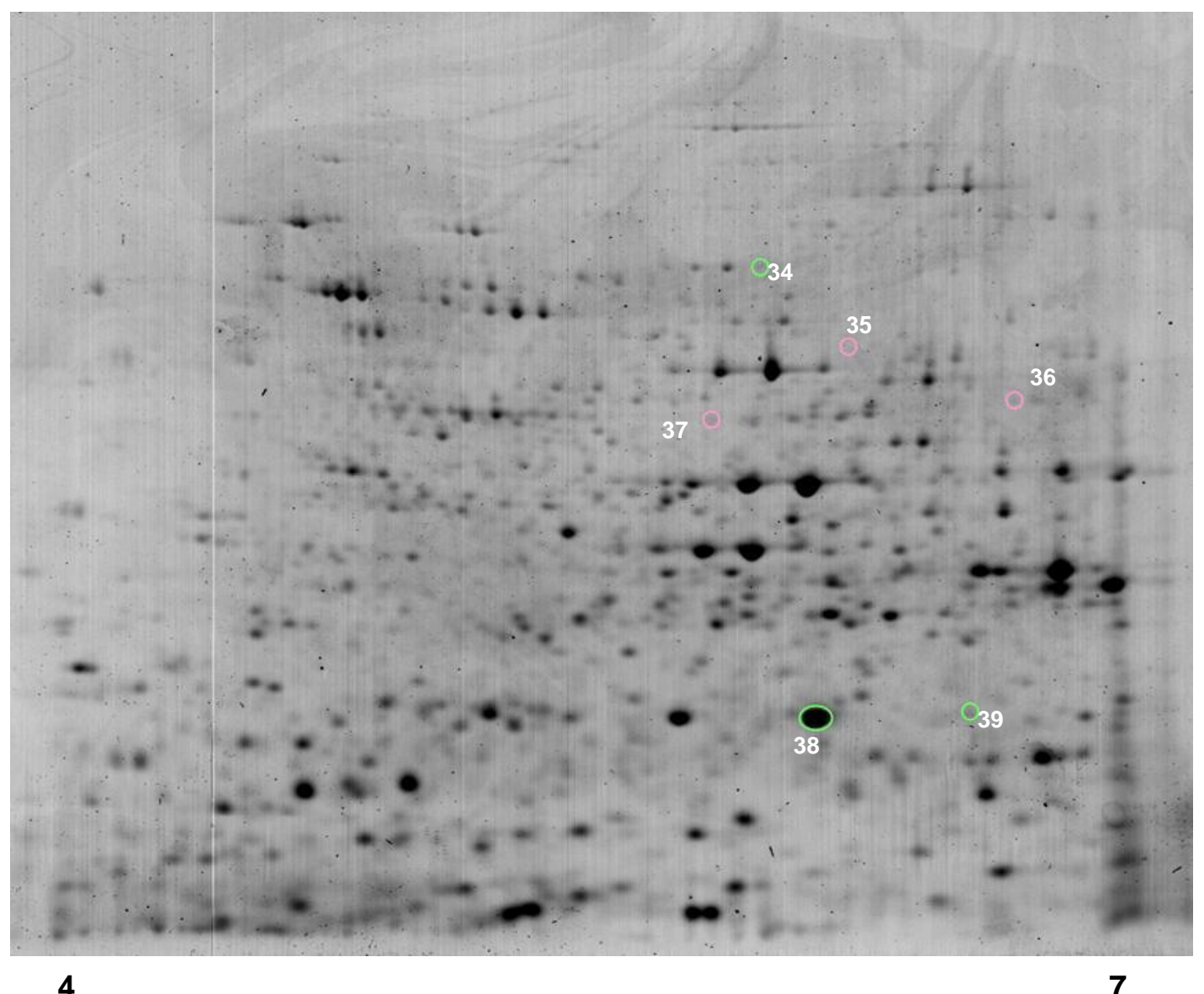

4

Figure $7 \mathrm{pH}$ 4-7 Coomassie blue stained gel of proteins from stationary phase wild type yeast cells treated with $12 \mu \mathrm{M}$ YTX for $24 \mathrm{~h}$. Pale green = tending towards a decrease in response to YTX treatment, but not significant (fold change $\geq 1.5 p \leq 0.05$ ). Pale pink $=$ tending towards an increase, but not significant (fold change $\geq 1.5 p \leq 0.05$ )

No changes in protein fold were detected between YTX treated and untreated cells. No changes in protein fold were detected between proteins from different treatment conditions when separated on a pH 6-11 linear gradient. 


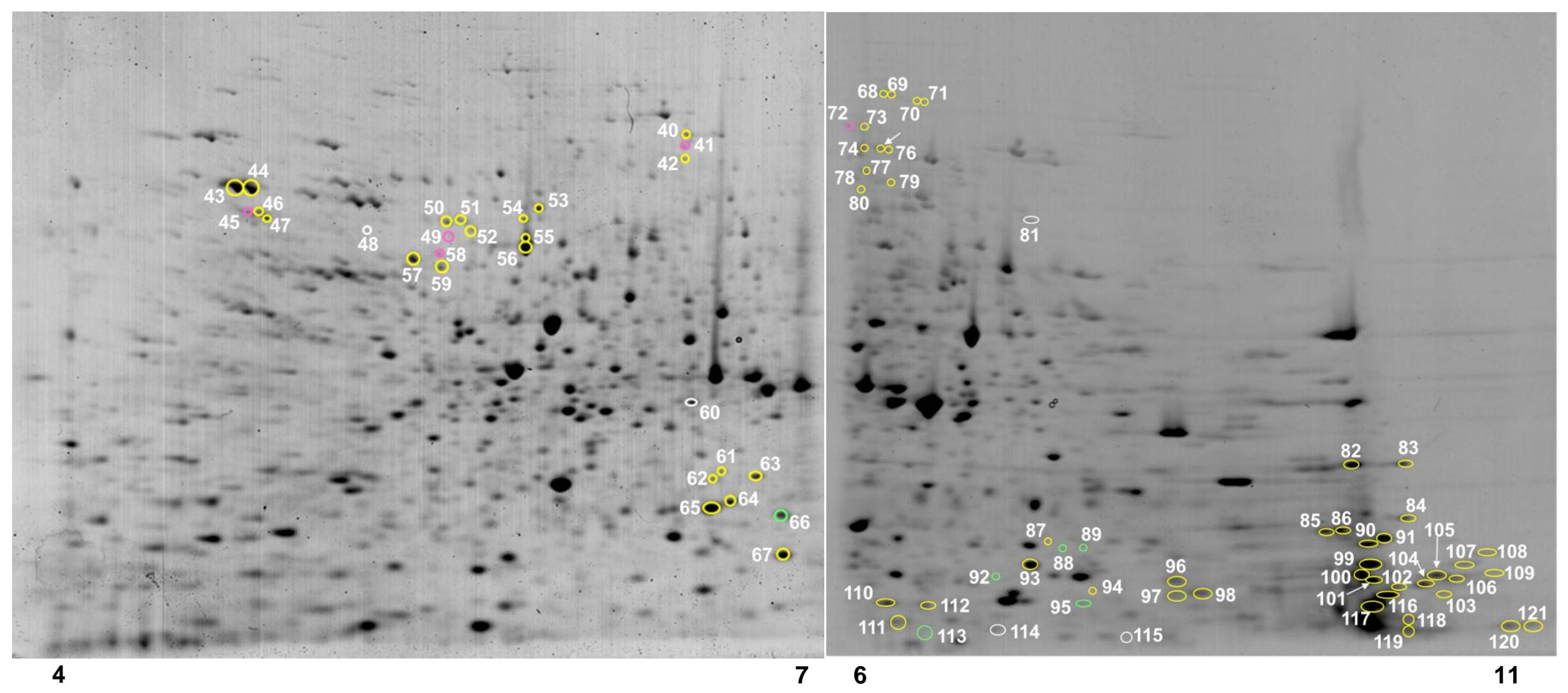

Figure 8 Coomassie blue stained gels, pH 4-7 and 6-11, of proteins extracted from log phase wild type yeast cells treated with $12 \mu \mathrm{M}$ YTX for $24 \mathrm{~h}$. Yellow = not changing. Pale green $=$ tending towards a fold decrease, but not significant (fold change $\geq 1.5, p \leq 0.05$ ). Pale pink $=$ tending towards an increase, but not significant (fold change $\geq$ $1.5 p \leq 0.05)$. White $=$ proteins which underwent a fold change when methanol and untreated cell extracts were compared. 

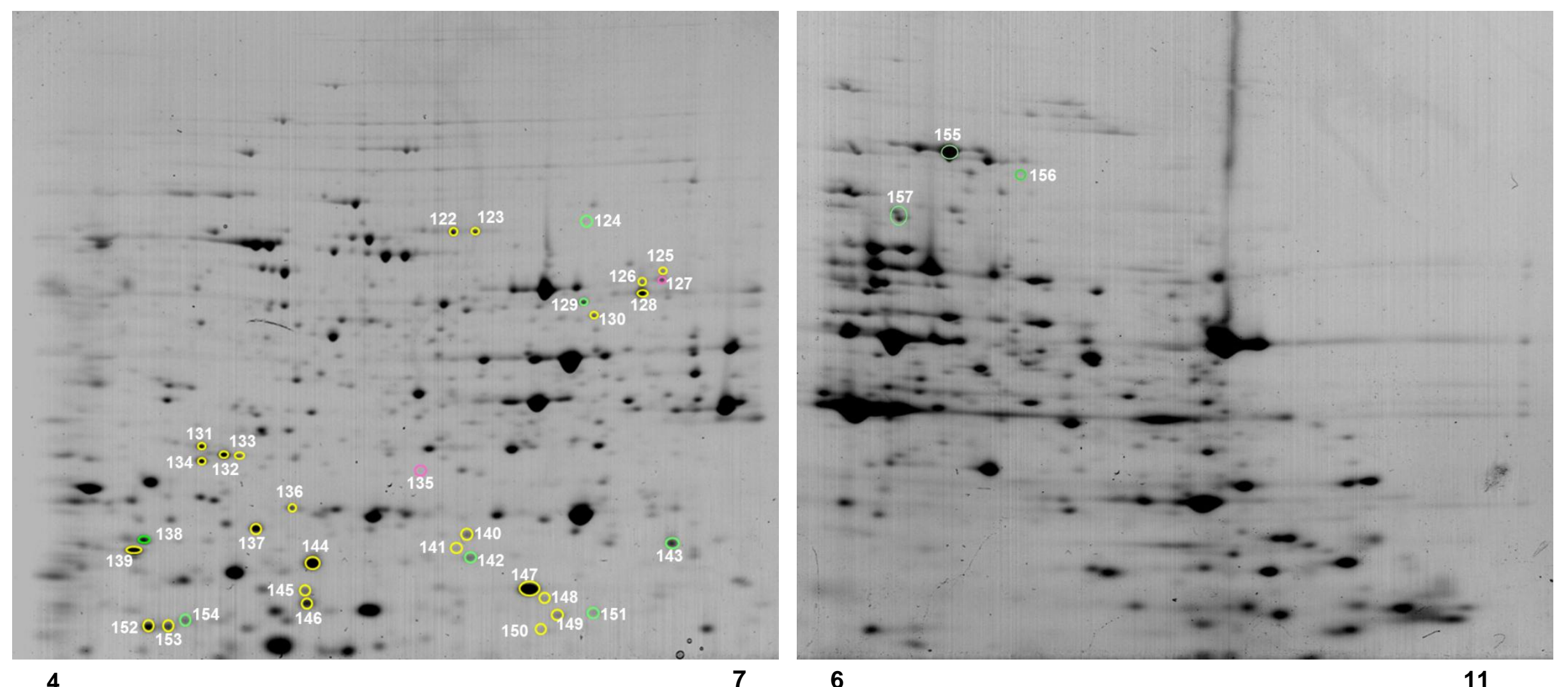

Figure 9 Coomassie blue stained gels, $\mathrm{pH}$ 4-7 and 6-11, of proteins extracted from stationary phase wild type yeast cells treated with $1.4 \mu \mathrm{M} \mathrm{ds} Y \mathrm{TX}$ for $24 \mathrm{~h}$. Yellow = not changing. Pale green $=$ tending towards significance (fold change $\geq 1.5, p \leq 0.05$ ). Green $=$ significant decrease (fold change $\geq 2$ fold, $p \leq 0.01$ ). Pink $=$ tending towards an increase, but not significant (fold change $\geq 1.5 p \leq 0.05$ ). 


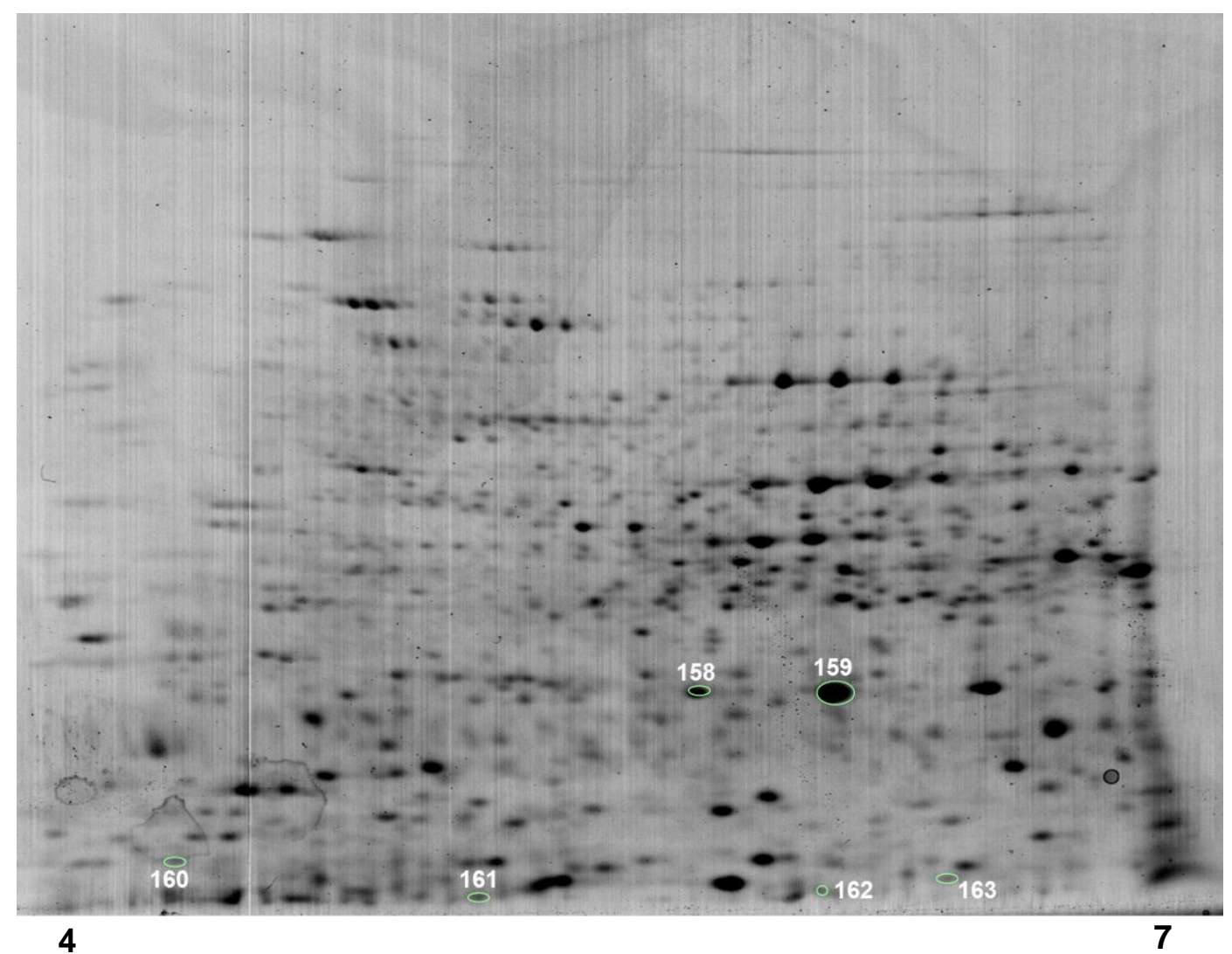

Figure 10 Coomassie blue stained gels, $\mathrm{pH}$ 4-7 of proteins extracted from log phase AD $\Delta$ mutant yeast cells, treated with $12 \mu \mathrm{M}$ YTX for 24 h. Pale green = tending towards significance (fold change $\geq 1.5, p \leq$ 0.05). No proteins of interest were identified amongst proteins separated on a $\mathrm{pH}$ 6-11 linear gradient. 

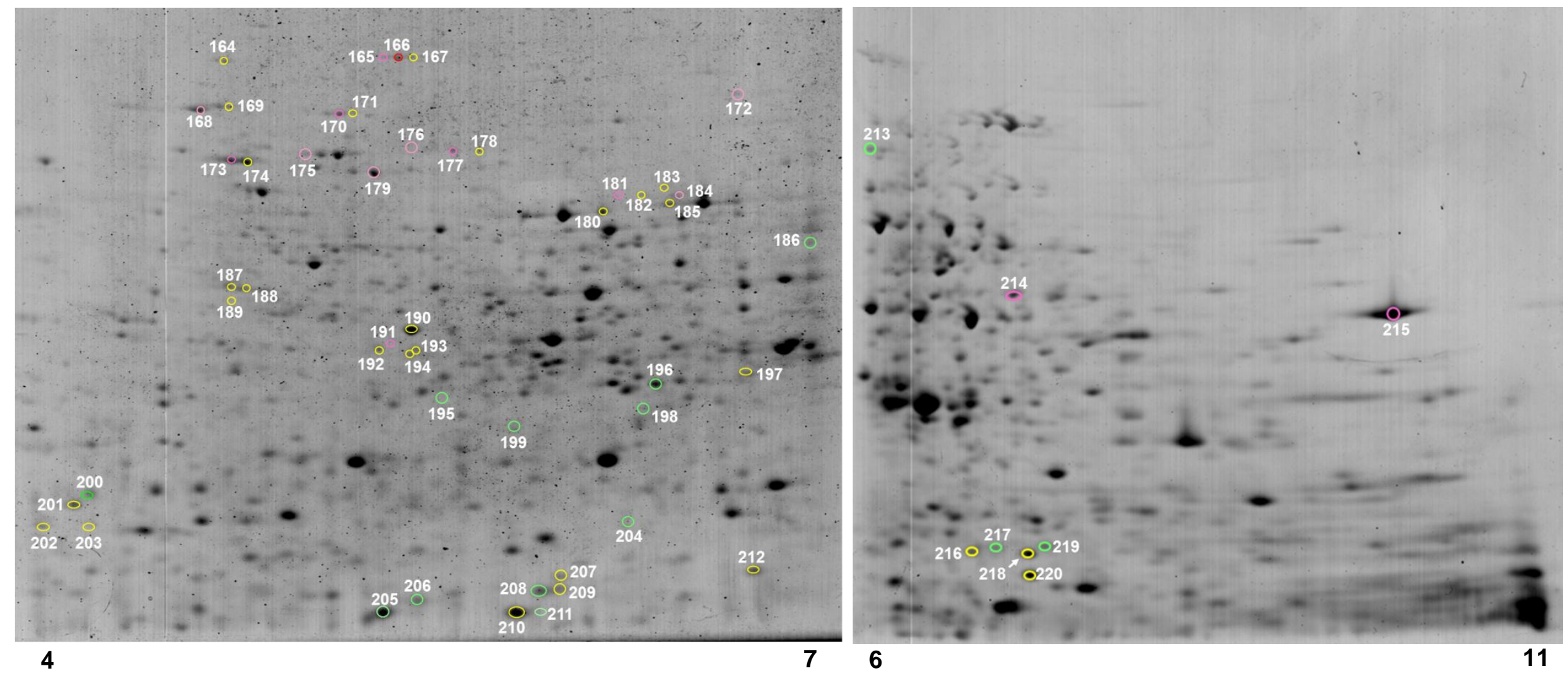

Figure 11 Coomassie blue stained gels, pH 4-7 and 6-11, of proteins extracted from stationary phase AD $\Delta$ mutant yeast cells, treated with $1.4 \mu \mathrm{M}$ ds $Y T X$ for $24 \mathrm{~h}$. Yellow = not changing. Pale green $=$ tending towards significance (fold change $\geq 1.5, p \leq 0.05$ ). Pale pink $=$ tending towards an increase, but not significant (fold change $\geq 1.5 p \leq$ 0.05). Red = significant increase (fold change $\geq 2, p \leq 0.01$ ). 


\subsubsection{Protein identification by peptide mass fingerprinting}

In total 76 protein spots which had a fold change in abundance of $\geq 1.5$-fold, $p \leq 0.05$ were detected. Thirty-nine of these were not excised from the gels for MALDI analysis due to low abundance. Of the remaining 37 spots, eight were identified. A further 36 proteins that had not changed in abundance were also identified. These protein spots are numbered in Figs 6 - 11. The DeCyder data and top ranked protein identification for each spot is displayed in Table 5. Identifications which did not reach the level of significance for confident identification of proteins have been included, to allow for comparison to results from HL-60 cells. Further identification data (including gi number, sequence coverage, expectation and lower ranked candidates) are reported in Appendix G and on the Supplementary Data CD.

No stationary phase $S$. cerevisiae proteins showed a significant change in abundance when treated with YTX. Two of the possible ( $\geq 1.5$-fold, $p \leq 0.05$ ) changes seen when wild type (BY4741) cells were treated with $1.2 \mu \mathrm{M}$ YTX were identified as cytosolic aldehyde dehydrogenase (Spot 10, Fig. 6, Table 5) and phosphoglycerate kinase (Spot 32, Fig. 6, Table 5).

Spot 138 showed a significant 2.37 fold decrease in abundance in wild type cells treated with dsYTX when compared to untreated controls ( $\mathrm{pH} \mathrm{4-7,} \mathrm{Fig.} \mathrm{9,} \mathrm{Table} \mathrm{5).} \mathrm{This}$ protein spot was identified as GRE1 protein. Mitochondrial aldehyde dehydrogenase was also identified as showing a possible change in abundance (Spot 129, Fig. 9Table 5).

The four significant changes seen when proteins from AD $\Delta$ cells treated with dsYTX (Fig. 11) are compared with proteins from untreated or methanol treated cells correspond to three proteins, two of which only change when compared with one control. Searching acquired spectra using MASCOT was unable to find matches to these spots with significant scores. The top-ranked match for each protein spot returned by the search were YKR101Wp-like protein (Spot 165), Pau9p hypothetical protein (Spot 166), which increased approximately 2.5 and 2-fold respectively, and mitochondrial translational activator (Spot 200), which decreased approximately 2.3 fold, compared to either control. HSP90-Sba1 closed chaperone complex (chain A) 
(Spot 168), YLL024Cp-like protein (Spot 173), ATPase involved in protein folding and nuclear transport (Spot 174), alcohol dehydrogenase I (Spot 211), and translational elongation factor $1 \alpha$, showed possible changes in abundance (Fig. 11, Table 5). HSP90B and elongation factor $1 \delta$ had altered abundances in HepG2 cells when treated with YTX.

The proteins which were identified with significant Mascot scores, but did not show any change in abundance by DIGE analysis are listed in Appendix $\mathrm{H}$.

A total of $212 \mathrm{MS}$ spectra were collected over all S. cerevisiae experiments. Of these 47 were identified with a significant Mascot score. Four of the remaining spectra did not provide a significant identification despite having signals and peak intensities that one would have expected to return a match. 
Table 5 S. cerevisiae protein abundance changes (Av. Ratio) and associated statistics acquired from DeCyder and protein identifications of proteins of interest and picked protein spots as numbered in Figs. 9 - 11. Bold statistics are significant ( $\geq 2$-fold, $p \leq 0.01$ ). N/A for protein name indicates that a protein spot was not selected for identification, either because it was low abundance or considered not to be due to toxin. Identifications in italics are those which did not have a significant match score. An absence of DeCyder statistics is indicative that a protein spot was not present in all protein spot maps. Av. Ratio is the protein volume of the first condition compared to the second in the comparison. For example negative value when comparing dsYTX/methanol (MeOH) means that the protein has undergone a decrease in abundance in response to dsYTX respective to the methanol treated control.

\begin{tabular}{|c|c|c|c|c|c|c|c|}
\hline Spot \# & Experiment & $\mathrm{pH}$ & Comparison & T-test & $\begin{array}{c}\text { Av. } \\
\text { Ratio }\end{array}$ & $\begin{array}{c}\text { 1-way } \\
\text { ANOVA }\end{array}$ & Name \\
\hline \multirow{3}{*}{1} & \multirow{3}{*}{$\begin{array}{l}\text { BY4741 } 1.2 \mu \mathrm{M} \\
\text { YTX }\end{array}$} & \multirow{3}{*}{$4-7$} & YTX/untreated & 0.17 & -1.3 & 0.19 & \multirow{3}{*}{ Formylglycinamidine-ribonucleotide (FGAM)-synthetase } \\
\hline & & & $\mathrm{YTX} / \mathrm{MeOH}$ & 0.52 & -1.1 & 0.19 & \\
\hline & & & $\mathrm{MeOH} /$ untreated & 0.089 & -1.18 & 0.19 & \\
\hline \multirow{3}{*}{2} & \multirow{3}{*}{$\begin{array}{l}\text { BY4741 } 1.2 \mu \mathrm{M} \\
\text { YTX }\end{array}$} & \multirow{3}{*}{$4-7$} & YTX/untreated & 0.58 & -1.19 & 0.46 & \multirow{3}{*}{ SSE1 protein, ATPase component of Hsp90 chaperone complex } \\
\hline & & & YTX/MeOH & 0.21 & -1.39 & 0.46 & \\
\hline & & & $\mathrm{MeOH} /$ untreated & 0.57 & 1.16 & 0.46 & \\
\hline \multirow{3}{*}{5} & \multirow{3}{*}{$\begin{array}{l}\text { BY4741 } 1.2 \mu \mathrm{M} \\
\text { YTX }\end{array}$} & \multirow{3}{*}{$4-7$} & YTX/untreated & 0.001 & -1.57 & 0.026 & \multirow{3}{*}{$\begin{array}{l}\text { Cytoplasmic tryptophanyl-tRNA synthetase } \\
\text { (Protein identification score was not significant) }\end{array}$} \\
\hline & & & $\mathrm{YTX} / \mathrm{MeOH}$ & 0.057 & -1.59 & 0.026 & \\
\hline & & & $\mathrm{MeOH} /$ untreated & 0.97 & 1.01 & 0.026 & \\
\hline \multirow{3}{*}{9} & \multirow{3}{*}{$\begin{array}{l}\text { BY4741 } 1.2 \mu \mathrm{M} \\
\text { YTX }\end{array}$} & \multirow{3}{*}{$4-7$} & YTX/untreated & 0.49 & -1.32 & 0.64 & \multirow{3}{*}{ Enolase II; Eno2p } \\
\hline & & & YTX/MeOH & 0.46 & -1.33 & 0.64 & \\
\hline & & & $\mathrm{MeOH} /$ untreated & 0.98 & 1.01 & 0.64 & \\
\hline \multirow{3}{*}{10} & \multirow{3}{*}{$\begin{array}{l}\text { BY4741 } 1.2 \mu \mathrm{M} \\
\text { YTX }\end{array}$} & \multirow{3}{*}{$4-7$} & YTX/untreated & 0.019 & -1.51 & 0.085 & \multirow{3}{*}{ Cytosolic aldehyde dehydrogenase; Ald6p } \\
\hline & & & YTX/MeOH & 0.14 & -1.44 & 0.085 & \\
\hline & & & $\mathrm{MeOH} /$ untreated & 0.73 & -1.05 & 0.085 & \\
\hline \multirow{3}{*}{11} & \multirow{3}{*}{$\begin{array}{l}\text { BY4741 } 1.2 \mu \mathrm{M} \\
\text { YTX }\end{array}$} & \multirow{3}{*}{$4-7$} & YTX/untreated & 0.4 & -1.21 & 0.12 & \multirow{3}{*}{ cytosolic aldehyde dehydrogenase } \\
\hline & & & YTX/MeOH & 0.13 & -1.6 & 0.12 & \\
\hline & & & $\mathrm{MeOH} /$ untreated & 0.037 & 1.32 & 0.12 & \\
\hline \multirow{3}{*}{12} & \multirow{3}{*}{$\begin{array}{l}\text { BY4741 } 1.2 \mu \mathrm{M} \\
\text { YTX }\end{array}$} & \multirow{3}{*}{$4-7$} & YTX/untreated & 0.55 & -1.24 & 0.57 & \multirow{3}{*}{ cytosolic aldehyde dehydrogenase } \\
\hline & & & YTX/MeOH & 0.27 & -1.29 & 0.57 & \\
\hline & & & $\mathrm{MeOH} /$ untreated & 0.81 & 1.05 & 0.57 & \\
\hline
\end{tabular}




\begin{tabular}{|c|c|c|c|c|c|c|c|}
\hline Spot \# & Experiment & $\mathrm{pH}$ & Comparison & T-test & Av. Ratio & $\begin{array}{c}\text { 1-way } \\
\text { ANOVA }\end{array}$ & Name \\
\hline \multirow{3}{*}{15} & \multirow{3}{*}{$\begin{array}{l}\text { BY4741 } 1.2 \mu \mathrm{M} \\
\quad \text { YTX }\end{array}$} & \multirow{3}{*}{$4-7$} & YTX/untreated & 0.42 & -1.18 & 0.41 & \multirow{3}{*}{ Threonine synthase; Thr4p } \\
\hline & & & YTX/MeOH & 0.21 & -1.24 & 0.41 & \\
\hline & & & $\mathrm{MeOH} /$ untreated & 0.75 & 1.05 & 0.41 & \\
\hline \multirow{3}{*}{16} & \multirow{3}{*}{$\begin{array}{l}\text { BY4741 } 1.2 \mu \mathrm{M} \\
\quad \text { YTX }\end{array}$} & \multirow{3}{*}{$4-7$} & YTX/untreated & 0.9 & -1.03 & 0.85 & \multirow{3}{*}{ Aromatic aminotransferase I; Aro8p } \\
\hline & & & YTX/MeOH & 0.64 & -1.15 & 0.85 & \\
\hline & & & $\mathrm{MeOH} /$ untreated & 0.73 & 1.12 & 0.85 & \\
\hline \multirow{3}{*}{17} & \multirow{3}{*}{$\begin{array}{l}\text { BY4741 } 1.2 \mu \mathrm{M} \\
\quad \text { YTX }\end{array}$} & \multirow{3}{*}{$4-7$} & YTX/untreated & 0.066 & -1.27 & 0.013 & \multirow{3}{*}{$\begin{array}{c}\text { Chain D, Crystal Structure Of Yeast Mitochondrial F1-Atpase } \\
\text { (Protein identification score was not significant) }\end{array}$} \\
\hline & & & $\mathrm{YTX} / \mathrm{MeOH}$ & 0.0065 & -1.5 & 0.013 & \\
\hline & & & $\mathrm{MeOH} /$ untreated & 0.13 & 1.19 & 0.013 & \\
\hline \multirow{3}{*}{18} & \multirow{3}{*}{$\begin{array}{l}\text { BY4741 } 1.2 \mu \mathrm{M} \\
\text { YTX }\end{array}$} & \multirow{3}{*}{$4-7$} & YTX/untreated & 0.83 & -1.07 & 0.71 & \multirow{3}{*}{ Enolase II; Eno2p } \\
\hline & & & YTX/MeOH & 0.42 & -1.19 & 0.71 & \\
\hline & & & $\mathrm{MeOH} /$ untreated & 0.6 & 1.11 & 0.71 & \\
\hline \multirow{6}{*}{19} & \multirow{6}{*}{$\begin{array}{l}\text { BY4741 } 1.2 \mu \mathrm{M} \\
\quad \text { YTX }\end{array}$} & \multirow{6}{*}{$4-7$} & YTX/untreated & 0.75 & -1.12 & 0.74 & \multirow{3}{*}{ Enolase II; Eno2p } \\
\hline & & & $\mathrm{YTX} / \mathrm{MeOH}$ & 0.45 & -1.21 & 0.74 & \\
\hline & & & $\mathrm{MeOH} /$ untreated & 0.71 & 1.08 & 0.74 & \\
\hline & & & YTX/untreated & 0.79 & -1.1 & 0.77 & \multirow{3}{*}{ Enolase II; Eno2p } \\
\hline & & & YTX/MeOH & 0.46 & -1.18 & 0.77 & \\
\hline & & & $\mathrm{MeOH} /$ untreated & 0.71 & 1.07 & 0.77 & \\
\hline \multirow{3}{*}{20} & \multirow{3}{*}{$\begin{array}{l}\text { BY4741 } 1.2 \mu \mathrm{M} \\
\quad \text { YTX }\end{array}$} & \multirow{3}{*}{$4-7$} & YTX/untreated & 0.39 & -1.47 & 0.6 & \multirow{3}{*}{ Enolase II; Eno2p } \\
\hline & & & YTX/MeOH & 0.61 & -1.31 & 0.6 & \\
\hline & & & $\mathrm{MeOH} /$ untreated & 0.7 & -1.12 & 0.6 & \\
\hline \multirow{3}{*}{22} & \multirow{3}{*}{$\begin{array}{l}\text { BY4741 } 1.2 \mu \mathrm{M} \\
\text { YTX }\end{array}$} & \multirow{3}{*}{$4-7$} & YTX/untreated & 0.87 & -1.03 & 0.86 & \multirow{3}{*}{ Fructose 1,6-bisphosphate aldolase; Fba1p } \\
\hline & & & $\mathrm{YTX} / \mathrm{MeOH}$ & 0.66 & -1.11 & 0.86 & \\
\hline & & & $\mathrm{MeOH} /$ untreated & 0.69 & 1.08 & 0.86 & \\
\hline \multirow{3}{*}{23} & & & YTX/untreated & & -1.31 & & \\
\hline & $\begin{array}{c}\text { BY4741 } 1.2 \mu \mathrm{M} \\
\text { YTX }\end{array}$ & $4-7$ & YTX/MeOH & & -1.2 & & Fructose 1,6-bisphosphate aldolase; Fba1p \\
\hline & & & $\mathrm{MeOH} /$ untreated & & -1.1 & & \\
\hline & & & YTX/untreated & 0.15 & -1.16 & 0.085 & \\
\hline 25 & $\begin{array}{c}\text { BY4/41 } 1.2 \mu \mathrm{IV} \\
\text { YTX }\end{array}$ & $4-7$ & $\mathrm{YTX} / \mathrm{MeOH}$ & 0.034 & -1.2 & 0.085 & $\begin{array}{l}\text { Subunit } d \text { of the five-subunit vo integral membrane domain of vacuolar } \\
\text { H+-ATPase (V-ATPase): Vma } 6 \mathrm{p}\end{array}$ \\
\hline & & & $\mathrm{MeOH} /$ untreated & 0.61 & 1.04 & 0.085 & \\
\hline
\end{tabular}




\begin{tabular}{|c|c|c|c|c|c|c|c|}
\hline Spot \# & Experiment & $\mathrm{pH}$ & Comparison & T-test & Av. Ratio & $\begin{array}{c}\text { 1-way } \\
\text { ANOVA }\end{array}$ & Name \\
\hline \multirow{3}{*}{26} & \multirow{3}{*}{$\begin{array}{l}\text { BY4741 } 1.2 \mu \mathrm{M} \\
\quad \text { YTX }\end{array}$} & \multirow{3}{*}{$4-7$} & YTX/untreated & 0.86 & 1.03 & 0.83 & \multirow{3}{*}{$\begin{array}{c}\text { Chain A, Electrophilic Catalysis In Triosephosphase Isomerase: The Role } \\
\text { Of Histidine-95 }\end{array}$} \\
\hline & & & YTX/MeOH & 0.6 & -1.07 & 0.83 & \\
\hline & & & $\mathrm{MeOH} /$ untreated & 0.61 & 1.11 & 0.83 & \\
\hline \multirow{3}{*}{27} & \multirow{3}{*}{$\begin{array}{l}\text { BY4741 } 1.2 \mu \mathrm{M} \\
\quad \text { YTX }\end{array}$} & \multirow{3}{*}{$6-11$} & YTX/untreated & 0.7 & -1.06 & 0.91 & \multirow{3}{*}{ pyruvate kinase } \\
\hline & & & YTX/MeOH & 0.88 & -1.03 & 0.91 & \\
\hline & & & $\mathrm{MeOH} /$ untreated & 0.77 & -1.03 & 0.91 & \\
\hline \multirow{3}{*}{$\begin{array}{c}28 \& \\
29\end{array}$} & \multirow{3}{*}{$\begin{array}{l}\text { BY4741 } 1.2 \mu \mathrm{M} \\
\quad \text { YTX }\end{array}$} & \multirow{3}{*}{$6-11$} & YTX/untreated & 0.85 & -1.03 & 0.98 & \multirow{3}{*}{ Chain A, Circularly Permuted Phosphoglycerate Kinase; Pgk P72 } \\
\hline & & & YTX/MeOH & 0.89 & -1.07 & 0.98 & \\
\hline & & & $\mathrm{MeOH} /$ untreated & 0.97 & 1.04 & 0.98 & \\
\hline \multirow{3}{*}{32} & \multirow{3}{*}{$\begin{array}{l}\text { BY4741 } 1.2 \mu \mathrm{M} \\
\text { YTX }\end{array}$} & \multirow{3}{*}{$6-11$} & YTX/untreated & 0.014 & -1.75 & 0.046 & \multirow{3}{*}{ Chain E, Saccharomyces Cerevisiae Phosphoglycerate Mutase } \\
\hline & & & YTX/MeOH & 0.084 & -1.64 & 0.046 & \\
\hline & & & $\mathrm{MeOH} /$ untreated & 0.71 & -1.06 & 0.046 & \\
\hline \multirow{3}{*}{33} & \multirow{3}{*}{$\begin{array}{l}\text { BY4741 } 1.2 \mu \mathrm{M} \\
\quad \text { YTX }\end{array}$} & \multirow{3}{*}{$6-11$} & YTX/untreated & 0.93 & -1.03 & 0.93 & \multirow{3}{*}{ Protein component of the small (40S) ribosomal subunit; Rps5p } \\
\hline & & & YTX/MeOH & 0.78 & 1.07 & 0.93 & \\
\hline & & & $\mathrm{MeOH} /$ untreated & 0.74 & -1.1 & 0.93 & \\
\hline \multirow{3}{*}{34} & \multirow{3}{*}{$\begin{array}{c}\text { BY4741 } 12 \mu \mathrm{M} \\
\text { YTX } \\
\text { (stationary) }\end{array}$} & \multirow{3}{*}{$4-7$} & YTX/untreated & 0.035 & -1.38 & 0.0061 & \multirow{3}{*}{$N / A$} \\
\hline & & & $\mathrm{YTX} / \mathrm{MeOH}$ & 0.0048 & -1.71 & 0.0061 & \\
\hline & & & $\mathrm{MeOH} /$ untreated & 0.026 & -1.34 & 0.012 & \\
\hline \multirow{3}{*}{35} & \multirow{3}{*}{$\begin{array}{c}\text { BY4741 } 12 \mu \mathrm{M} \\
\text { YTX } \\
\text { (stationary) }\end{array}$} & \multirow{3}{*}{$4-7$} & YTX/untreated & 0.048 & 1.34 & 0.016 & \multirow{3}{*}{$N / A$} \\
\hline & & & YTX/MeOH & 0.032 & 1.81 & 0.016 & \\
\hline & & & $\mathrm{MeOH} /$ untreated & 0.091 & 1.24 & 0.0061 & \\
\hline \multirow{3}{*}{36} & \multirow{3}{*}{$\begin{array}{c}\text { BY4741 } 12 \mu \mathrm{M} \\
\text { YTX } \\
\text { (stationary) }\end{array}$} & & YTX/untreated & 0.032 & 1.43 & 0.0066 & \\
\hline & & $4-7$ & YTX/MeOH & 0.015 & 1.74 & 0.0066 & $N / A$ \\
\hline & & & $\mathrm{MeOH} /$ untreated & 0.095 & -1.27 & 0.031 & \\
\hline 27 & BY4741 $12 \mu \mathrm{M}$ & & YTX/untreated & 0.086 & 1.48 & 0.024 & \\
\hline 37 & YTX & $4-7$ & YTX/MeOH & 0.0036 & 1.78 & 0.024 & $N / A$ \\
\hline & (stationary) & & $\mathrm{MeOH} /$ untreated & 0.11 & -1.44 & 0.029 & \\
\hline & BY4741 $12 \mu \mathrm{M}$ & & YTX/untreated & 0.057 & -1.42 & 0.023 & \\
\hline 38 & YTX & $4-7$ & YTX/MeOH & 0.044 & -1.53 & 0.023 & $N / A$ \\
\hline & (stationary) & & $\mathrm{MeOH} /$ untreated & 0.35 & 1.08 & 0.012 & \\
\hline
\end{tabular}




\begin{tabular}{|c|c|c|c|c|c|c|c|}
\hline Spot \# & Experiment & $\mathrm{pH}$ & Comparison & T-test & Av. Ratio & $\begin{array}{c}\text { 1-way } \\
\text { ANOVA }\end{array}$ & Name \\
\hline \multirow{3}{*}{39} & \multirow{3}{*}{$\begin{array}{c}\text { BY4741 } 12 \mu \mathrm{M} \\
\text { YTX } \\
\text { (stationary) }\end{array}$} & \multirow{3}{*}{$4-7$} & YTX/untreated & 0.13 & -1.52 & 0.048 & \multirow{3}{*}{$N / A$} \\
\hline & & & $\mathrm{YTX} / \mathrm{MeOH}$ & 0.046 & -1.92 & 0.048 & \\
\hline & & & $\mathrm{MeOH} /$ untreated & 0.27 & -1.21 & 0.024 & \\
\hline \multirow{3}{*}{41} & \multirow{3}{*}{$\begin{array}{c}\text { BY4741 } 12 \mu \mathrm{M} \\
\text { YTX } \\
\text { (log) }\end{array}$} & \multirow{3}{*}{$4-7$} & YTX/untreated & 0.025 & 1.58 & 0.025 & \multirow{3}{*}{$\begin{array}{c}\text { Unknown } \\
\text { (Protein identification score was not significant) }\end{array}$} \\
\hline & & & $\mathrm{YTX} / \mathrm{MeOH}$ & 0.86 & 1.02 & 0.025 & \\
\hline & & & $\mathrm{MeOH} /$ untreated & 0.05 & 1.55 & 0.025 & \\
\hline \multirow{3}{*}{43} & \multirow{3}{*}{$\begin{array}{c}\text { BY4741 } 12 \mu \mathrm{M} \\
\text { YTX } \\
(\log ) \\
\end{array}$} & \multirow{3}{*}{$4-7$} & YTX/untreated & 0.21 & 1.54 & 0.13 & \multirow{3}{*}{ YLL024Cp-like protein AWRI1631 } \\
\hline & & & YTX/MeOH & 0.5 & -1.1 & 0.13 & \\
\hline & & & $\mathrm{MeOH} /$ untreated & 0.12 & 1.7 & 0.13 & \\
\hline \multirow{3}{*}{44} & \multirow{3}{*}{$\begin{array}{c}\text { BY4741 } 12 \mu \mathrm{M} \\
\text { YTX } \\
(\log )\end{array}$} & \multirow{3}{*}{$4-7$} & YTX/untreated & 0.16 & 1.44 & 0.077 & \multirow{3}{*}{ ATPase; Ssa1p } \\
\hline & & & $\mathrm{YTX} / \mathrm{MeOH}$ & 0.31 & -1.11 & 0.077 & \\
\hline & & & $\mathrm{MeOH} /$ untreated & 0.083 & 1.6 & 0.077 & \\
\hline \multirow{3}{*}{45} & \multirow{3}{*}{$\begin{array}{c}\text { BY4741 } 12 \mu \mathrm{M} \\
\text { YTX } \\
\text { (log) }\end{array}$} & \multirow{3}{*}{$4-7$} & YTX/untreated & 0.013 & 1.63 & 0.0072 & \multirow{3}{*}{$\begin{array}{c}\text { Unknown } \\
\text { (Protein identification score was not significant) }\end{array}$} \\
\hline & & & YTX/MeOH & 0.79 & 1.02 & 0.0072 & \\
\hline & & & $\mathrm{MeOH} /$ untreated & 0.013 & 1.59 & 0.0072 & \\
\hline \multirow{3}{*}{48} & \multirow{3}{*}{$\begin{array}{c}\text { BY4741 } 12 \mu \mathrm{M} \\
\text { YTX } \\
(\log ) \\
\end{array}$} & \multirow{3}{*}{$4-7$} & YTX/untreated & 0.017 & 1.5 & 0.025 & \multirow{3}{*}{$N / A$} \\
\hline & & & $\mathrm{YTX} / \mathrm{MeOH}$ & 0.65 & -1.06 & 0.025 & \\
\hline & & & $\mathrm{MeOH} /$ untreated & 0.042 & 1.59 & 0.025 & \\
\hline \multirow{3}{*}{49} & \multirow{3}{*}{$\begin{array}{c}\text { BY4741 } 12 \mu \mathrm{M} \\
\text { YTX } \\
(\log ) \\
\end{array}$} & \multirow{3}{*}{$4-7$} & YTX/untreated & 0.0015 & 1.75 & 0.0043 & \multirow{3}{*}{$\begin{array}{l}\text { Chain A, The Structure Of Tap42 Alpha4 Subunit } \\
\text { (Protein identification score was not significant) }\end{array}$} \\
\hline & & & YTX/MeOH & 0.55 & -1.06 & 0.0043 & \\
\hline & & & $\mathrm{MeOH} /$ untreated & 0.015 & 1.86 & 0.0043 & \\
\hline \multirow{3}{*}{58} & \multirow{3}{*}{$\begin{array}{c}\text { BY4741 } 12 \mu \mathrm{M} \\
\text { YTX } \\
(\log ) \\
\end{array}$} & & YTX/untreated & 0.018 & 1.51 & 0.013 & \\
\hline & & $4-7$ & YTX/MeOH & 0.99 & 1 & 0.013 & No hit \\
\hline & & & $\mathrm{MeOH} /$ untreated & 0.022 & 1.5 & 0.013 & \\
\hline & BY4741 $12 \mu \mathrm{M}$ & & YTX/untreated & 0.057 & -1.53 & 0.019 & \\
\hline 60 & YTX & $4-7$ & YTX/MeOH & 0.1 & 1.09 & 0.019 & $N / A$ \\
\hline & $(\log )$ & & $\mathrm{MeOH} /$ untreated & 0.038 & -1.66 & 0.019 & \\
\hline & BY4741 $12 \mu \mathrm{M}$ & & YTX/untreated & 0.31 & -1.13 & 0.72 & \\
\hline 62 & YTX & $4-7$ & YTX/MeOH & 0.92 & 1.01 & 0.72 & YLL024Cp-like protein AWRI1631 \\
\hline & $(\log )$ & & $\mathrm{MeOH} /$ untreated & 0.56 & -1.14 & 0.72 & \\
\hline
\end{tabular}




\begin{tabular}{|c|c|c|c|c|c|c|c|}
\hline Spot \# & Experiment & $\mathrm{pH}$ & Comparison & T-test & Av. Ratio & $\begin{array}{c}\text { 1-way } \\
\text { ANOVA }\end{array}$ & Name \\
\hline \multirow{3}{*}{66} & \multirow{3}{*}{$\begin{array}{l}\text { BY4741 } 12 \mu \mathrm{M} \\
\text { YTX } \\
(\log )\end{array}$} & \multirow{3}{*}{$4-7$} & YTX/untreated & 0.026 & -1.5 & 0.027 & \multirow{3}{*}{ No hit } \\
\hline & & & $\mathrm{YTX} / \mathrm{MeOH}$ & 0.54 & 1.06 & 0.027 & \\
\hline & & & $\mathrm{MeOH} /$ untreated & 0.053 & -1.6 & 0.027 & \\
\hline \multirow{3}{*}{72} & \multirow{3}{*}{$\begin{array}{l}\text { BY4741 } 12 \mu \mathrm{M} \\
\text { YTX } \\
(\log )\end{array}$} & \multirow{3}{*}{$6-11$} & YTX/untreated & 0.047 & 1.63 & 0.018 & \multirow{3}{*}{$\begin{array}{l}\text { Hypothetical protein identified by homology; Pau9p } \\
\text { (Protein identification score was not significant) }\end{array}$} \\
\hline & & & YTX/MeOH & 0.85 & -1.02 & 0.018 & \\
\hline & & & $\mathrm{MeOH} /$ untreated & 0.015 & 1.66 & 0.018 & \\
\hline \multirow{3}{*}{81} & \multirow{3}{*}{$\begin{array}{l}\text { BY4741 } 12 \mu \mathrm{M} \\
\text { YTX } \\
\text { (log) }\end{array}$} & \multirow{3}{*}{$6-11$} & YTX/untreated & 0.096 & 1.44 & 0.041 & \multirow{3}{*}{$N / A$} \\
\hline & & & YTX/MeOH & 0.49 & -1.08 & 0.041 & \\
\hline & & & $\mathrm{MeOH} /$ untreated & 0.033 & 1.55 & 0.041 & \\
\hline \multirow{3}{*}{88} & \multirow{3}{*}{$\begin{array}{l}\text { BY4741 } 12 \mu \mathrm{M} \\
\text { YTX } \\
\text { (log) }\end{array}$} & \multirow{3}{*}{$6-11$} & YTX/untreated & 0.0057 & -1.56 & 0.0049 & \multirow{3}{*}{$\begin{array}{c}I c s 2 p \\
\text { (Protein identification score was not significant) }\end{array}$} \\
\hline & & & YTX/MeOH & 0.19 & -1.1 & 0.0049 & \\
\hline & & & $\mathrm{MeOH} /$ untreated & 0.025 & -1.42 & 0.0049 & \\
\hline \multirow{3}{*}{89} & \multirow{3}{*}{$\begin{array}{l}\text { BY4741 } 12 \mu \mathrm{M} \\
\text { YTX } \\
(\log )\end{array}$} & \multirow{3}{*}{$6-11$} & YTX/untreated & 0.023 & -1.55 & 0.036 & \multirow{3}{*}{$N / A$} \\
\hline & & & YTX/MeOH & 0.68 & -1.06 & 0.036 & \\
\hline & & & $\mathrm{MeOH} /$ untreated & 0.059 & -1.46 & 0.036 & \\
\hline \multirow{3}{*}{92} & \multirow{3}{*}{$\begin{array}{l}\text { BY4741 } 12 \mu \mathrm{M} \\
\text { YTX } \\
(\log )\end{array}$} & \multirow{3}{*}{$6-11$} & YTX/untreated & 0.027 & -1.52 & 0.041 & \multirow{3}{*}{$\begin{array}{c}\text { YNLO22Cp-like protein AWRI1631 } \\
\text { (Protein identification score was not significant) }\end{array}$} \\
\hline & & & YTX/MeOH & 0.96 & -1.01 & 0.041 & \\
\hline & & & $\mathrm{MeOH} /$ untreated & 0.058 & -1.51 & 0.041 & \\
\hline \multirow{3}{*}{93} & \multirow{3}{*}{$\begin{array}{l}\text { BY4741 } 12 \mu \mathrm{M} \\
\text { YTX } \\
\text { (log) }\end{array}$} & \multirow{3}{*}{$6-11$} & YTX/untreated & 0.061 & -1.45 & 0.033 & \multirow{3}{*}{$N / A$} \\
\hline & & & YTX/MeOH & 0.72 & 1.04 & 0.033 & \\
\hline & & & $\mathrm{MeOH} /$ untreated & 0.04 & -1.51 & 0.033 & \\
\hline \multirow{3}{*}{95} & \multirow{3}{*}{$\begin{array}{l}\text { BY4741 } 12 \mu \mathrm{M} \\
\text { YTX } \\
\text { (log) }\end{array}$} & & YTX/untreated & 0.012 & -1.62 & 0.033 & \\
\hline & & $6-11$ & YTX/MeOH & 0.47 & -1.12 & 0.033 & $N / A$ \\
\hline & & & MeOH/untreated & 0.084 & -1.45 & 0.033 & \\
\hline & BY4741 $12 \mu \mathrm{M}$ & & YTX/untreated & 0.066 & -1.19 & 0.077 & \\
\hline 96 & YTX & $6-11$ & YTX/MeOH & 0.84 & 1.01 & 0.077 & Nucleoside diphosphate kinase; Ynk1p \\
\hline & $(\log )$ & & $\mathrm{MeOH} /$ untreated & 0.11 & -1.2 & 0.077 & \\
\hline & BY4741 $12 \mu \mathrm{M}$ & & YTX/untreated & 0.063 & -1.75 & 0.026 & \\
\hline 98 & YTX & $6-11$ & YTX/MeOH & 0.54 & 1.05 & 0.026 & $\begin{array}{l}\text { Thymidylate synthase; Cdc21p } \\
\text { (Protein identification score }\end{array}$ \\
\hline & $(\log )$ & & $\mathrm{MeOH} /$ untreated & 0.048 & -1.83 & 0.026 & \\
\hline
\end{tabular}




\begin{tabular}{|c|c|c|c|c|c|c|c|}
\hline Spot \# & Experiment & pH & Comparison & T-test & Av. Ratio & $\begin{array}{l}\text { 1-way } \\
\text { ANOVA }\end{array}$ & Name \\
\hline \multirow{3}{*}{113} & \multirow{3}{*}{$\begin{array}{l}\text { BY4741 } 12 \mu \mathrm{M} \\
\text { YTX } \\
\text { (log) }\end{array}$} & \multirow{3}{*}{$6-11$} & YTX/untreated & 0.029 & -1.57 & 0.01 & \multirow{3}{*}{$\begin{array}{c}\text { Ydr381wp } \\
\text { (Protein identification score was not significant) }\end{array}$} \\
\hline & & & $\mathrm{YTX} / \mathrm{MeOH}$ & 0.11 & -1.02 & 0.01 & \\
\hline & & & $\mathrm{MeOH} /$ untreated & 0.033 & -1.54 & 0.01 & \\
\hline \multirow{3}{*}{114} & \multirow{3}{*}{$\begin{array}{l}\text { BY4741 } 12 \mu \mathrm{M} \\
\text { YTX } \\
\text { (log) }\end{array}$} & \multirow{3}{*}{$6-11$} & YTX/untreated & 0.064 & -1.55 & 0.032 & \multirow{3}{*}{$N / A$} \\
\hline & & & YTX/MeOH & 1 & 1 & 0.032 & \\
\hline & & & $\mathrm{MeOH} /$ untreated & 0.044 & -1.55 & 0.032 & \\
\hline \multirow{3}{*}{115} & \multirow{3}{*}{$\begin{array}{l}\text { BY4741 } 12 \mu \mathrm{M} \\
\text { YTX } \\
\text { (log) }\end{array}$} & \multirow{3}{*}{$6-11$} & YTX/untreated & 0.063 & -1.94 & 0.036 & \multirow{3}{*}{$N / A$} \\
\hline & & & YTX/MeOH & 0.78 & -1.04 & 0.036 & \\
\hline & & & $\mathrm{MeOH} /$ untreated & 0.036 & -1.86 & 0.036 & \\
\hline \multirow{3}{*}{123} & \multirow{3}{*}{ BY4741 dsYTX } & \multirow{3}{*}{$4-7$} & dsYTX/untreated & 0.89 & -1.01 & 0.88 & \multirow{3}{*}{ Hsp90 cochaperone; Sti1p } \\
\hline & & & dsYTX/MeOH & 0.61 & -1.02 & 0.88 & \\
\hline & & & $\mathrm{MeOH} /$ untreated & 0.8 & 1.01 & 0.88 & \\
\hline \multirow{3}{*}{124} & \multirow{3}{*}{ BY4741 dsYTX } & \multirow{3}{*}{$4-7$} & dsYTX/untreated & 0.032 & -1.36 & 0.03 & \multirow[t]{3}{*}{$N / A$} \\
\hline & & & dsYTX/MeOH & 0.044 & -1.58 & 0.03 & \\
\hline & & & $\mathrm{MeOH} /$ untreated & 0.29 & 1.16 & 0.03 & \\
\hline \multirow{3}{*}{127} & \multirow{3}{*}{ BY4741 dsYTX } & \multirow{3}{*}{$4-7$} & dsYTX/untreated & 0.0079 & 1.51 & 0.0024 & \multirow{3}{*}{$\begin{array}{l}\text { Thymidylate synthase; } C d c 21 p \\
\text { (Protein identification score was not significant) }\end{array}$} \\
\hline & & & dsYTX/MeOH & 0.01 & 1.39 & 0.0024 & \\
\hline & & & $\mathrm{MeOH} /$ untreated & 0.11 & 1.09 & 0.0024 & \\
\hline \multirow{3}{*}{129} & \multirow{3}{*}{ BY4741 dsYTX } & \multirow{3}{*}{$4-7$} & YTX/untreated & 0.028 & -1.59 & 0.012 & \multirow{3}{*}{ Mitochondrial aldehyde dehydrogenase; Ald4p } \\
\hline & & & YTX/MeOH & 0.012 & -1.67 & 0.012 & \\
\hline & & & $\mathrm{MeOH} /$ untreated & 0.64 & 1.05 & 0.012 & \\
\hline \multirow{3}{*}{135} & \multirow{3}{*}{ BY4741 dsYTX } & & dsYTX/untreated & 0.077 & 1.36 & 0.025 & \\
\hline & & $4-7$ & dsYTX/MeOH & 0.031 & 1.59 & 0.025 & $N / A$ \\
\hline & & & $\mathrm{MeOH} /$ untreated & 0.17 & -1.17 & 0.025 & \\
\hline & & & dsYTX/untreated & 0.6 & -1.02 & 0.89 & \\
\hline 136 & BY4741 dsYTX & $4-7$ & dsYTX/MeOH & 0.94 & -1 & 0.89 & Phosphomannomutase; Sec53p \\
\hline & & & $\mathrm{MeOH} /$ untreated & 0.78 & -1.01 & 0.89 & \\
\hline & & & YTX/untreated & 0.29 & -1.12 & 0.4 & $5 \sigma d 2$ \\
\hline 137 & BY4741 dsYTX & $4-7$ & YTX/MeOH & 0.91 & 1.01 & 0.4 & $\operatorname{Egd} 2 p$ \\
\hline & & & $\mathrm{MeOH} /$ untreated & 0.25 & -1.13 & 0.4 & \\
\hline
\end{tabular}




\begin{tabular}{|c|c|c|c|c|c|c|c|}
\hline Spot \# & Experiment & $\mathrm{pH}$ & Comparison & T-test & Av. Ratio & $\begin{array}{c}\text { 1-way } \\
\text { ANOVA }\end{array}$ & Name \\
\hline \multirow{3}{*}{138} & \multirow{3}{*}{ BY4741 dsYTX } & \multirow{3}{*}{$4-7$} & dsYTX/untreated & 0.0046 & -2.37 & 0.0039 & \multirow{3}{*}{ protein GRE1 RM11-1a } \\
\hline & & & dsYTX/MeOH & 0.021 & -1.84 & 0.0039 & \\
\hline & & & $\mathrm{MeOH} /$ untreated & 0.11 & -1.28 & 0.0039 & \\
\hline \multirow{3}{*}{142} & \multirow{3}{*}{ BY4741 dsYTX } & \multirow{3}{*}{$4-7$} & dsYTX/untreated & 0.0086 & -1.52 & 0.0061 & \multirow{3}{*}{$\begin{array}{l}\text { Hypothetical protein identified by homology; Pau9p } \\
\text { (Protein identification score was not significant) }\end{array}$} \\
\hline & & & dsYTX/MeOH & 0.017 & -1.39 & 0.0061 & \\
\hline & & & $\mathrm{MeOH} /$ untreated & 0.26 & -1.09 & 0.0061 & \\
\hline \multirow{3}{*}{143} & \multirow{3}{*}{ BY4741 dsYTX } & \multirow{3}{*}{$4-7$} & dsYTX/untreated & 0.056 & -1.56 & 0.027 & \multirow{3}{*}{$N / A$} \\
\hline & & & dsYTX/MeOH & 0.043 & -1.54 & 0.027 & \\
\hline & & & $\mathrm{MeOH} /$ untreated & 0.86 & -1.02 & 0.027 & \\
\hline \multirow{3}{*}{147} & \multirow{3}{*}{ BY4741 dsYTX } & \multirow{3}{*}{$4-7$} & dsYTX/untreated & 0.94 & -1.01 & 0.32 & \multirow{3}{*}{ Chain A, H48c Yeast Cu(li)ZN SUPEROXIDE DISMUTASE Structure } \\
\hline & & & dsYTX/MeOH & 0.27 & 1.26 & 0.32 & \\
\hline & & & $\mathrm{MeOH} /$ untreated & 0.24 & -1.28 & 0.32 & \\
\hline \multirow{3}{*}{150} & \multirow{3}{*}{ BY4741 dsYTX } & \multirow{3}{*}{$4-7$} & dsYTX/untreated & 0.046 & 1.34 & 0.18 & \multirow{3}{*}{$\begin{array}{l}\text { Chain G, Yeast Cytochrome Bc1 Complex With Bound Substrate } \\
\text { Cytochrome C }\end{array}$} \\
\hline & & & $\mathrm{dsYTX/MeOH}$ & 0.29 & 1.18 & 0.18 & \\
\hline & & & $\mathrm{MeOH} /$ untreated & 0.5 & 1.13 & 0.18 & \\
\hline \multirow{3}{*}{151} & \multirow{3}{*}{ BY4741 dsYTX } & \multirow{3}{*}{$4-7$} & dsYTX/untreated & 0.0025 & -1.54 & 0.00081 & \multirow{3}{*}{$N / A$} \\
\hline & & & dsYTX/MeOH & 0.0057 & -1.55 & 0.00081 & \\
\hline & & & $\mathrm{MeOH} /$ untreated & 0.88 & 1 & 0.00081 & \\
\hline \multirow{3}{*}{154} & \multirow{3}{*}{ BY4741 dsYTX } & \multirow{3}{*}{$4-7$} & dsYTX/untreated & 0.026 & -2.08 & 0.018 & \multirow{3}{*}{$\begin{array}{c}\text { Chain O, Structure Of The Ribosomal 80s-Eef2-Sordarin Complex } \\
\text { (Protein identification score was not significant) }\end{array}$} \\
\hline & & & dsYTX/MeOH & 0.038 & -1.63 & 0.018 & \\
\hline & & & $\mathrm{MeOH} /$ untreated & 0.2 & -1.27 & 0.018 & \\
\hline \multirow{3}{*}{155} & \multirow{3}{*}{ BY4741 dsYTX } & & dsYTX/untreated & 0.06 & -1.66 & 0.032 & \\
\hline & & $6-11$ & dsYTX/MeOH & 0.042 & -1.8 & 0.032 & $N / A$ \\
\hline & & & $\mathrm{MeOH} /$ untreated & 0.53 & 1.09 & 0.032 & \\
\hline & & & YTX/untreated & 0.0061 & -2.13 & 0.024 & \\
\hline 156 & BY4741 dsYTX & $6-11$ & $\mathrm{YTX} / \mathrm{MeOH}$ & 0.046 & -2.33 & 0.024 & $N / A$ \\
\hline & & & $\mathrm{MeOH} /$ untreated & 0.74 & 1.09 & 0.024 & \\
\hline & & & dsYTX/untreated & 0.051 & -1.87 & 0.024 & \\
\hline $15 /$ & BY4741 dsYTX & $6-11$ & $\mathrm{dsYTX} / \mathrm{MeOH}$ & 0.044 & -2.28 & 0.024 & $N / A$ \\
\hline & & & $\mathrm{MeOH} /$ untreated & 0.23 & 1.22 & 0.024 & \\
\hline
\end{tabular}




\begin{tabular}{|c|c|c|c|c|c|c|c|}
\hline Spot \# & Experiment & $\mathrm{pH}$ & Comparison & T-test & Av. Ratio & $\begin{array}{c}\text { 1-way } \\
\text { ANOVA }\end{array}$ & Name \\
\hline \multirow{3}{*}{158} & \multirow{3}{*}{$\begin{array}{l}\text { AD } \Delta 12 \mu \mathrm{M} \text { YTX } \\
\text { (log) }\end{array}$} & \multirow{3}{*}{$4-7$} & YTX/untreated & 0.034 & -1.58 & 0.009 & \multirow{3}{*}{$N / A$} \\
\hline & & & $\mathrm{YTX} / \mathrm{MeOH}$ & 0.018 & -1.78 & 0.009 & \\
\hline & & & $\mathrm{MeOH} /$ untreated & 0.15 & 1.13 & 0.009 & \\
\hline \multirow{3}{*}{159} & \multirow{3}{*}{$\begin{array}{c}\mathrm{AD} \Delta 12 \mu \mathrm{M} \text { YTX } \\
\text { (log) }\end{array}$} & \multirow{3}{*}{$4-7$} & YTX/untreated & 0.085 & -1.38 & 0.028 & \multirow{3}{*}{$N / A$} \\
\hline & & & YTX/MeOH & 0.036 & -1.53 & 0.028 & \\
\hline & & & $\mathrm{MeOH} /$ untreated & 0.19 & 1.11 & 0.028 & \\
\hline \multirow{3}{*}{160} & \multirow{3}{*}{$\begin{array}{c}\text { AD } \Delta 12 \mu \mathrm{M} \text { YTX } \\
\text { (log) }\end{array}$} & \multirow{3}{*}{$4-7$} & YTX/untreated & 0.013 & -1.69 & 0.0024 & \multirow{3}{*}{$N / A$} \\
\hline & & & YTX/MeOH & 0.0018 & -1.74 & 0.0024 & \\
\hline & & & $\mathrm{MeOH} /$ untreated & 0.59 & 1.03 & 0.0024 & \\
\hline \multirow{3}{*}{161} & \multirow{3}{*}{$\begin{array}{l}\mathrm{AD} \Delta 12 \mu \mathrm{M} \text { YTX } \\
\text { (log) }\end{array}$} & \multirow{3}{*}{$4-7$} & YTX/untreated & 0.1 & -1.9 & 0.045 & \multirow{3}{*}{$N / A$} \\
\hline & & & $\mathrm{YTX} / \mathrm{MeOH}$ & 0.018 & -2.18 & 0.045 & \\
\hline & & & $\mathrm{MeOH} /$ untreated & 0.53 & 1.15 & 0.045 & \\
\hline \multirow{3}{*}{162} & \multirow{3}{*}{$\begin{array}{c}\text { AD } \Delta 12 \mu \mathrm{M} \text { YTX } \\
(\log )\end{array}$} & \multirow{3}{*}{$4-7$} & YTX/untreated & 0.07 & -1.67 & 0.041 & \multirow{3}{*}{$N / A$} \\
\hline & & & YTX/MeOH & 0.036 & -1.79 & 0.041 & \\
\hline & & & $\mathrm{MeOH} /$ untreated & 0.68 & 1.07 & 0.041 & \\
\hline \multirow{3}{*}{163} & \multirow{3}{*}{$\begin{array}{l}\text { AD } \Delta 12 \mu \mathrm{M} \text { YTX } \\
\text { (log) }\end{array}$} & \multirow{3}{*}{$4-7$} & YTX/untreated & 0.02 & -2.17 & 0.02 & \multirow{3}{*}{$N / A$} \\
\hline & & & YTX/MeOH & 0.042 & -1.99 & 0.02 & \\
\hline & & & $\mathrm{MeOH} /$ untreated & 0.62 & -1.09 & 0.02 & \\
\hline \multirow{3}{*}{164} & \multirow{3}{*}{$\mathrm{AD} \Delta \mathrm{dsYTX}$} & \multirow{3}{*}{$4-7$} & dsYTX/untreated & 0.095 & 1.75 & 0.066 & \multirow{3}{*}{$\begin{array}{l}\text { Phosphatidylinositol transfer protein (PITP); Pdr16p } \\
\text { (Protein identification score was not significant) }\end{array}$} \\
\hline & & & dsYTX/MeOH & 0.011 & 1.68 & 0.066 & \\
\hline & & & $\mathrm{MeOH} /$ untreated & 0.82 & 1.04 & 0.066 & \\
\hline \multirow{3}{*}{165} & \multirow{3}{*}{$\mathrm{AD} \Delta \mathrm{dsYTX}$} & & dsYTX/untreated & 0.021 & 2.41 & 0.0059 & \\
\hline & & $4-7$ & dsYTX/MeOH & 0.0099 & 2.5 & 0.0059 & YRR101Wp-llke proteIn AWRI1631 \\
\hline & & & $\mathrm{MeOH} /$ untreated & 0.79 & -1.04 & 0.0059 & \\
\hline & & & dsYTX/untreated & 0.0063 & 2.04 & 0.02 & \\
\hline 166 & AD $\triangle$ dsYTX & $4-7$ & dsYTX/MeOH & 0.043 & 2.06 & 0.02 & Hypothetical proteln Identifled by homology; Paugp \\
\hline & & & $\mathrm{MeOH} /$ untreated & 0.91 & -1.01 & 0.02 & (Protein identification score was not significant) \\
\hline 160 & & & dsYTX/untreated & 0.065 & 1.61 & 0.045 & \\
\hline 168 & AD $\triangle \mathrm{dsYTX}$ & $4-7$ & dsYTX/MeOH & 0.045 & 1.66 & 0.045 & Chain A, Crystal Structure Of An Hsp90-Sba1 Closed Chaperone Complex \\
\hline & & & $\mathrm{MeOH} /$ untreated & 0.85 & -1.03 & 0.045 & \\
\hline
\end{tabular}




\begin{tabular}{|c|c|c|c|c|c|c|c|}
\hline Spot \# & Experiment & $\mathrm{pH}$ & Comparison & T-test & $\begin{array}{c}\text { Av. } \\
\text { Ratio }\end{array}$ & $\begin{array}{c}\text { 1-way } \\
\text { ANOVA }\end{array}$ & Name \\
\hline \multirow{3}{*}{170} & \multirow{3}{*}{$\mathrm{AD} \Delta \mathrm{dsYTX}$} & \multirow{3}{*}{$4-7$} & dsYTX/untreated & 0.027 & 1.78 & 0.014 & \multirow{3}{*}{$\begin{array}{l}\text { Chain A, Crystal Structure Analysis Of Sse1, A Yeast Hsp110 } \\
\text { (Protein identification score was not significant) }\end{array}$} \\
\hline & & & $\mathrm{dsYTX/MeOH}$ & 0.026 & 1.89 & 0.014 & \\
\hline & & & $\mathrm{MeOH} /$ untreated & 0.61 & -1.06 & 0.014 & \\
\hline \multirow{3}{*}{172} & \multirow{3}{*}{$\mathrm{AD} \Delta \mathrm{dsYTX}$} & \multirow{3}{*}{$4-7$} & dsYTX/untreated & 0.14 & 1.42 & 0.035 & \multirow{3}{*}{$N / A$} \\
\hline & & & dsYTX/MeOH & 0.013 & 1.85 & 0.035 & \\
\hline & & & $\mathrm{MeOH} /$ untreated & 0.2 & -1.31 & 0.035 & \\
\hline \multirow{3}{*}{173} & \multirow{3}{*}{$\mathrm{AD} \Delta \mathrm{dsYTX}$} & \multirow{3}{*}{$4-7$} & dsYTX/untreated & 0.1 & 1.85 & 0.049 & \multirow{3}{*}{ YLL024Cp-like protein AWRI1631 } \\
\hline & & & dsYTX/MeOH & 0.036 & 2.04 & 0.049 & \\
\hline & & & $\mathrm{MeOH} /$ untreated & 0.67 & -1.1 & 0.049 & \\
\hline \multirow{3}{*}{174} & \multirow{3}{*}{$\mathrm{AD} \Delta \mathrm{dsYTX}$} & \multirow{3}{*}{$4-7$} & dsYTX/untreated & 0.087 & 1.62 & 0.052 & \multirow{3}{*}{$\begin{array}{l}\text { ATPase involved in protein folding and nuclear localisation signal (NLS)- } \\
\text { directed nuclear transport; Ssa1p }\end{array}$} \\
\hline & & & dsYTX/MeOH & 0.023 & 1.58 & 0.052 & \\
\hline & & & $\mathrm{MeOH} /$ untreated & 0.81 & 1.03 & 0.052 & \\
\hline \multirow{3}{*}{175} & \multirow{3}{*}{$\mathrm{AD} \Delta \mathrm{dsYTX}$} & \multirow{3}{*}{$4-7$} & dsYTX/untreated & 0.074 & 1.32 & 0.034 & \multirow{3}{*}{$N / A$} \\
\hline & & & dsYTX/MeOH & 0.042 & 1.66 & 0.034 & \\
\hline & & & $\mathrm{MeOH} /$ untreated & 0.18 & -1.26 & 0.034 & \\
\hline \multirow{3}{*}{176} & \multirow{3}{*}{$\mathrm{AD} \Delta \mathrm{dsYTX}$} & \multirow{3}{*}{$4-7$} & dsYTX/untreated & 0.054 & 1.56 & 0.024 & \multirow{3}{*}{$N / A$} \\
\hline & & & dsYTX/MeOH & 0.012 & 1.56 & 0.024 & \\
\hline & & & $\mathrm{MeOH} /$ untreated & 0.98 & -1 & 0.024 & \\
\hline \multirow{3}{*}{177} & \multirow{3}{*}{$\mathrm{AD} \Delta \mathrm{dsYTX}$} & \multirow{3}{*}{$4-7$} & dsYTX/untreated & 0.024 & 1.95 & 0.021 & \multirow{3}{*}{$\begin{array}{l}\text { Hypothetical protein identified by homology; Pau9p } \\
\text { (Protein identification score was not significant) }\end{array}$} \\
\hline & & & dsYTX/MeOH & 0.05 & 1.82 & 0.021 & \\
\hline & & & $\mathrm{MeOH} /$ untreated & 0.64 & 1.07 & 0.021 & \\
\hline \multirow{3}{*}{179} & \multirow{3}{*}{$\mathrm{AD} \Delta \mathrm{dsYTX}$} & & dsYTX/untreated & 0.06 & 1.51 & 0.036 & \\
\hline & & $4-7$ & dsYTX/MeOH & 0.025 & 1.61 & 0.036 & $N / A$ \\
\hline & & & $\mathrm{MeOH} /$ untreated & 0.66 & -1.07 & 0.036 & \\
\hline & & & dsYTX/untreated & 0.012 & 1.5 & 0.013 & \\
\hline 181 & $\mathrm{AD} \Delta \mathrm{dsYTX}$ & $4-7$ & $\mathrm{dsYTX} / \mathrm{MeOH}$ & 0.03 & 1.66 & 0.013 & Hypothetical protein identified by homology; Pau9p \\
\hline & & & $\mathrm{MeOH} /$ untreated & 0.33 & -1.1 & 0.013 & \\
\hline & & & dsYTX/untreated & 0.074 & 1.6 & 0.029 & \\
\hline 184 & $\mathrm{AD} \Delta \mathrm{dsYTX}$ & $4-7$ & dsYTX/MeOH & 0.047 & 1.82 & 0.029 & One of SIX AlPases of the 195 regulatory particle of the 265 proteasome; \\
\hline & & & $\mathrm{MeOH} /$ untreated & 0.22 & -1.14 & 0.029 & \\
\hline
\end{tabular}




\begin{tabular}{|c|c|c|c|c|c|c|c|}
\hline Spot \# & Experiment & $\mathrm{pH}$ & Comparison & T-test & Av. Ratio & $\begin{array}{c}\text { 1-way } \\
\text { ANOVA }\end{array}$ & Name \\
\hline \multirow{3}{*}{186} & \multirow{3}{*}{$\mathrm{AD} \Delta \mathrm{dsYTX}$} & \multirow{3}{*}{$4-7$} & dsYTX/untreated & 0.19 & -1.19 & 0.034 & \multirow{3}{*}{$N / A$} \\
\hline & & & dsYTX/MeOH & 0.036 & -1.5 & 0.034 & \\
\hline & & & $\mathrm{MeOH} /$ untreated & 0.085 & 1.26 & 0.034 & \\
\hline \multirow{3}{*}{188} & \multirow{3}{*}{$\mathrm{AD} \Delta \mathrm{dsYTX}$} & \multirow{3}{*}{$4-7$} & dsYTX/untreated & 0.062 & 1.31 & 0.042 & \multirow{3}{*}{ YLL024Cp-like protein AWRI1631 } \\
\hline & & & dsYTX/MeOH & 0.09 & 1.26 & 0.042 & \\
\hline & & & $\mathrm{MeOH} /$ untreated & 0.38 & 1.04 & 0.042 & \\
\hline \multirow{3}{*}{190} & \multirow{3}{*}{$\mathrm{AD} \Delta \mathrm{dsYTX}$} & \multirow{3}{*}{$4-7$} & dsYTX/untreated & 0.13 & 1.27 & 0.072 & \multirow{3}{*}{ actin } \\
\hline & & & dsYTX/MeOH & 0.042 & 1.36 & 0.072 & \\
\hline & & & $\mathrm{MeOH} /$ untreated & 0.52 & -1.08 & 0.072 & \\
\hline \multirow{3}{*}{191} & \multirow{3}{*}{$\mathrm{AD} \Delta \mathrm{dsYTX}$} & \multirow{3}{*}{$4-7$} & dsYTX/untreated & 0.044 & 1.63 & 0.019 & \multirow{3}{*}{$\begin{array}{c}\text { YGL071Wp-like protein AWRI1631 } \\
\text { (Protein identification score was not significant) }\end{array}$} \\
\hline & & & dsYTX/MeOH & 0.015 & 1.65 & 0.019 & \\
\hline & & & $\mathrm{MeOH} /$ untreated & 0.94 & -1.01 & 0.019 & \\
\hline \multirow{3}{*}{195} & \multirow{3}{*}{ AD $\Delta$ dsYTX } & \multirow{3}{*}{$4-7$} & dsYTX/untreated & 0.022 & -1.33 & 0.003 & \multirow{3}{*}{$N / A$} \\
\hline & & & dsYTX/MeOH & 0.0078 & -1.58 & 0.003 & \\
\hline & & & $\mathrm{MeOH} /$ untreated & 0.031 & 1.19 & 0.003 & \\
\hline \multirow{3}{*}{196} & \multirow{3}{*}{$\mathrm{AD} \Delta \mathrm{dsYTX}$} & \multirow{3}{*}{$4-7$} & dsYTX/untreated & 0.08 & -1.22 & 0.0063 & \multirow{3}{*}{$N / A$} \\
\hline & & & $\mathrm{dsYTX/MeOH}$ & 0.011 & -1.59 & 0.0063 & \\
\hline & & & $\mathrm{MeOH} /$ untreated & 0.023 & 1.3 & 0.0063 & \\
\hline \multirow{3}{*}{198} & \multirow{3}{*}{$\mathrm{AD} \Delta \mathrm{dsYTX}$} & \multirow{3}{*}{$4-7$} & dsYTX/untreated & 0.053 & -1.42 & 0.036 & \multirow{3}{*}{$N / A$} \\
\hline & & & dsYTX/MeOH & 0.029 & -1.5 & 0.036 & \\
\hline & & & $\mathrm{MeOH} /$ untreated & 0.65 & 1.06 & 0.036 & \\
\hline \multirow{3}{*}{199} & \multirow{3}{*}{$\mathrm{AD} \Delta \mathrm{dsYTX}$} & & dsYTX/untreated & 0.067 & -1.44 & 0.019 & \\
\hline & & $4-7$ & dsYTX/MeOH & 0.035 & -1.66 & 0.019 & $N / A$ \\
\hline & & & $\mathrm{MeOH} /$ untreated & 0.065 & 1.15 & 0.019 & \\
\hline 200 & & & dsYTX/untreated & 0.0005 & -2.26 & 0.00027 & \\
\hline 200 & AD $\Delta$ dsYTX & $4-7$ & dsYTX/MeOH & 0.0023 & -2.36 & 0.00027 & Mitochondrial translational activator YJM789 \\
\hline & & & $\mathrm{MeOH} /$ untreated & 0.43 & 1.04 & 0.00027 & \\
\hline & & & dsYTX/untreated & 0.45 & 1.16 & 0.54 & \\
\hline 201 & AD $\Delta \mathrm{dsYTX}$ & $4-7$ & $\mathrm{dsYTX} / \mathrm{MeOH}$ & 0.36 & 1.15 & 0.54 & conserved protein YJM789 \\
\hline & & & MeOH/untreated & 0.94 & 1.01 & 0.54 & \\
\hline
\end{tabular}




\begin{tabular}{|c|c|c|c|c|c|c|c|}
\hline Spot \# & Experiment & $\mathrm{pH}$ & Comparison & T-test & Av. Ratio & $\begin{array}{c}\text { 1-way } \\
\text { ANOVA }\end{array}$ & Name \\
\hline \multirow{3}{*}{204} & \multirow{3}{*}{ AD $\Delta$ dsYTX } & \multirow{3}{*}{$4-7$} & dsYTX/untreated & 0.011 & -1.34 & 0.0083 & \multirow{3}{*}{$N / A$} \\
\hline & & & dsYTX/MeOH & 0.021 & -1.51 & 0.0083 & \\
\hline & & & $\mathrm{MeOH} /$ untreated & 0.18 & 1.12 & 0.0083 & \\
\hline \multirow{3}{*}{205} & \multirow{3}{*}{$\mathrm{AD} \Delta \mathrm{dsYTX}$} & \multirow{3}{*}{$4-7$} & dsYTX/untreated & 0.028 & -1.7 & 0.02 & \multirow{3}{*}{$\begin{array}{l}\text { Putative protein of unknown function; Ylr146w-ap } \\
\text { (Protein identification score was not significant) }\end{array}$} \\
\hline & & & dsYTX/MeOH & 0.023 & -1.81 & 0.02 & \\
\hline & & & $\mathrm{MeOH} /$ untreated & 0.68 & 1.06 & 0.02 & \\
\hline \multirow{3}{*}{206} & \multirow{3}{*}{$\mathrm{AD} \Delta \mathrm{dsYTX}$} & \multirow{3}{*}{$4-7$} & dsYTX/untreated & 0.019 & -1.37 & 0.005 & \multirow{3}{*}{$\begin{array}{c}\text { One of six subunits of the RNA polymerase III transcription initiation factor } \\
\text { complex (TFIIIC); Tfc1p } \\
\text { (Protein identification score was not significant) }\end{array}$} \\
\hline & & & dsYTX/MeOH & 0.0056 & -1.53 & 0.005 & \\
\hline & & & $\mathrm{MeOH} /$ untreated & 0.19 & 1.11 & 0.005 & \\
\hline \multirow{3}{*}{207} & \multirow{3}{*}{$\mathrm{AD} \Delta \mathrm{dsYTX}$} & \multirow{3}{*}{$4-7$} & dsYTX/untreated & 0.69 & 1.06 & 0.52 & \multirow{3}{*}{$\begin{array}{l}\text { Chain G, Yeast Cytochrome Bc1 Complex With Bound Substrate } \\
\text { Cytochrome C }\end{array}$} \\
\hline & & & dsYTX/MeOH & 0.37 & 1.12 & 0.52 & \\
\hline & & & $\mathrm{MeOH} /$ untreated & 0.29 & -1.07 & 0.52 & \\
\hline \multirow{3}{*}{208} & \multirow{3}{*}{$\mathrm{AD} \Delta \mathrm{dsYTX}$} & \multirow{3}{*}{$4-7$} & dsYTX/untreated & 0.011 & -1.28 & 0.027 & \multirow[t]{3}{*}{ YGR254Wp-like protein AWRI1631 } \\
\hline & & & dsYTX/MeOH & 0.046 & -1.42 & 0.027 & \\
\hline & & & $\mathrm{MeOH} /$ untreated & 0.33 & 1.11 & 0.027 & \\
\hline \multirow{3}{*}{209} & \multirow{3}{*}{ AD $\Delta$ dsYTX } & \multirow{3}{*}{$4-7$} & dsYTX/untreated & 0.002 & -1.45 & 0.029 & \multirow{3}{*}{ YGR254Wp-like protein AWRI1631 } \\
\hline & & & dsYTX/MeOH & 0.052 & -1.65 & 0.029 & \\
\hline & & & $\mathrm{MeOH} /$ untreated & 0.4 & 1.14 & 0.029 & \\
\hline \multirow{3}{*}{210} & \multirow{3}{*}{$\mathrm{AD} \Delta \mathrm{dsYTX}$} & \multirow{3}{*}{$4-7$} & dsYTX/untreated & & -1.72 & & \multirow{3}{*}{ Enolase II; Eno2p } \\
\hline & & & dsYTX/MeOH & & -1.57 & & \\
\hline & & & $\mathrm{MeOH} /$ untreated & & -1.1 & & \\
\hline \multirow{3}{*}{211} & \multirow{3}{*}{$\mathrm{AD} \Delta \mathrm{dsYTX}$} & & dsYTX/untreated & 0.0025 & -1.49 & 0.022 & \\
\hline & & $4-7$ & dsYTX/MeOH & 0.049 & -1.54 & 0.022 & dehydrogenase isozyme I, alcohol \\
\hline & & & $\mathrm{MeOH} /$ untreated & 0.8 & 1.03 & 0.022 & \\
\hline 212 & & & dsYTX/untreated & 0.02 & 1.41 & 0.0036 & \\
\hline 213 & $\mathrm{AD} \Delta \mathrm{dsYTX}$ & $6-11$ & $\mathrm{dsYTX/MeOH}$ & 0.0058 & 1.58 & 0.0036 & $N / A$ \\
\hline & & & $\mathrm{MeOH} /$ untreated & 0.11 & -1.13 & 0.0036 & \\
\hline & & & dsYTX/untreated & 0.067 & 1.82 & 0.027 & \\
\hline 214 & AD $\Delta$ dsYTX & $6-11$ & dsYTX/MeOH & 0.036 & 1.95 & 0.027 & $N / A$ \\
\hline & & & $\mathrm{MeOH} /$ untreated & 0.57 & -1.07 & 0.027 & \\
\hline
\end{tabular}




\begin{tabular}{|c|c|c|c|c|c|c|c|}
\hline Spot \# & Experiment & $\mathrm{pH}$ & Comparison & T-test & Av. Ratio & $\begin{array}{c}\text { 1-way } \\
\text { ANOVA }\end{array}$ & Name \\
\hline \multirow{3}{*}{215} & \multirow{3}{*}{$\mathrm{AD} \Delta \mathrm{dsYTX}$} & \multirow{3}{*}{$6-11$} & dsYTX/untreated & 0.11 & 1.69 & 0.037 & \multirow{3}{*}{ Translational elongation factor EF-1 alpha; Tef2p, TEF1 } \\
\hline & & & $\mathrm{dsYTX/MeOH}$ & 0.026 & 2.1 & 0.037 & \\
\hline & & & $\mathrm{MeOH} /$ untreated & 0.3 & -1.24 & 0.037 & \\
\hline \multirow{3}{*}{217} & \multirow{3}{*}{$\mathrm{AD} \Delta \mathrm{dsYTX}$} & \multirow{3}{*}{$6-11$} & dsYTX/untreated & 0.014 & -2.09 & 0.02 & \multirow{3}{*}{$\begin{array}{c}\text { Unnamed protein product } \\
\text { (Protein identification score was not significant) }\end{array}$} \\
\hline & & & dsYTX/MeOH & 0.044 & -2.14 & 0.02 & \\
\hline & & & $\mathrm{MeOH} /$ untreated & 0.95 & 1.02 & 0.02 & \\
\hline \multirow{3}{*}{218} & \multirow{3}{*}{ AD $\Delta$ dsYTX } & \multirow{3}{*}{$6-11$} & dsYTX/untreated & 0.42 & -1.11 & 0.43 & \multirow{3}{*}{ pyruvate kinase } \\
\hline & & & dsYTX/MeOH & 0.13 & -1.14 & 0.43 & \\
\hline & & & $\mathrm{MeOH} /$ untreated & 0.81 & 1.03 & 0.43 & \\
\hline \multirow{3}{*}{219} & \multirow{3}{*}{ AD $\Delta$ dsYTX } & \multirow{3}{*}{$6-11$} & dsYTX/untreated & 0.0016 & -1.59 & 0.017 & \multirow{3}{*}{$\begin{array}{l}\text { Alcohol dehydrogenase isoenzyme } V ; \text { Adh5p } \\
\text { (Protein identification score was not significant) }\end{array}$} \\
\hline & & & dsYTX/MeOH & 0.038 & -1.82 & 0.017 & \\
\hline & & & $\mathrm{MeOH} /$ untreated & 0.39 & 1.15 & 0.017 & \\
\hline \multirow{3}{*}{220} & \multirow{3}{*}{$\mathrm{AD} \Delta \mathrm{ds} \mathrm{YTX}$} & \multirow{3}{*}{$6-11$} & dsYTX/untreated & 0.2 & -1.33 & 0.093 & \multirow{3}{*}{ pyruvate kinase } \\
\hline & & & dsYTX/MeOH & 0.014 & -1.49 & 0.093 & \\
\hline & & & $\mathrm{MeOH} /$ untreated & 0.47 & 1.12 & 0.093 & \\
\hline
\end{tabular}




\subsection{HL-60 cells}

HL60 cells were cultured until they were approximately $80 \%$ confluent. The cells were then divided into $10 \mathrm{~mL}$ cultures containing $9 \times 10^{6}$ cells. Samples were then treated with $1 \mu \mathrm{M}$ of YTX or dsYTX. Control samples were treated with methanol $(0.02 \% \mathrm{v} / \mathrm{v}$ final concentration).

\subsubsection{Morphological analysis}

The morphology of all HL60 samples was observed at $0 \mathrm{~h}$ and $24 \mathrm{~h}$ after incubation with toxin or methanol control. No obvious morphological differences were observed in flasks of cells treated with YTX or control samples (Fig. 12). After $24 \mathrm{~h}$ of incubation flasks of cells treated with dsYTX had clumps of floating cells (Fig. 13). Staining of the cells with trypan blue indicated that cells in these clumps were dead.

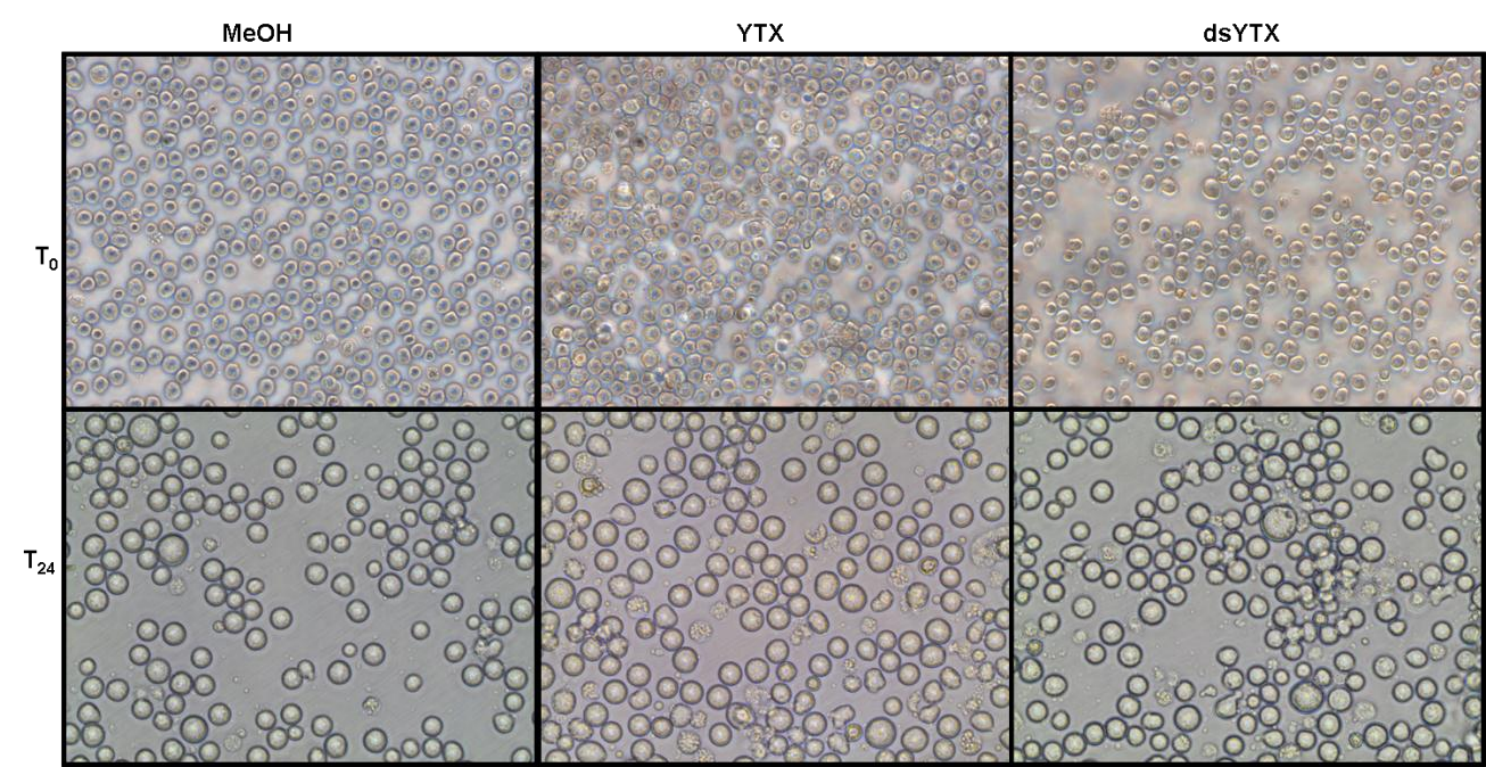

Figure $12 \mathrm{HL} 60$ cells in culture at 0 and $24 \mathrm{~h}$ after addition of toxin at 20x magnification. No morphological differences were observed in flasks of cells treated with toxin compared with control cells treated with methanol, with the exception of clumps forming in dsYTX treated cultures. 


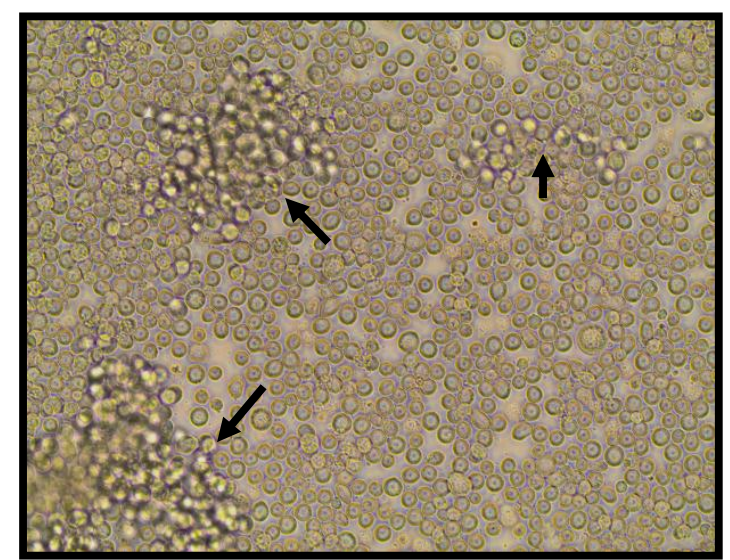

Figure 13 HL60 cells after $24 \mathrm{~h}$ incubation with dsYTX at 10x magnification. Arrows indicate aggregated cells.

Analysis of trypan blue staining gave a percentage cell viability of $86.1 \%$ at $0 \mathrm{~h}$. After $24 \mathrm{~h}$ of incubation the percentage cell viability was $91.7 \%$ for control samples incubated with methanol, and $79.0 \%$ and $67.7 \%$ for samples incubated YTX and dsYTX respectively.

\subsubsection{D-DIGE analysis}

The effects of YTX and dsYTX on HL60 cells were examined using 2D DIGE. The goal was to identify proteins that changed for comparison with known effects of YTX on HepG2 cells (Young et al., 2009), and to the microtubule stabilising agent Pel A on HL60 cells (Wilmes et al., 2012). The protein extracts treated with $1 \mu \mathrm{M}$ YTX or dsYTX and control samples $(0.02 \%$ methanol) were analysed for changes in levels of protein expression by 2D DIGE. A change in protein abundance $\geq 2$-fold, $p \leq 0.01$ was again considered significant. MALDI mass fingerprinting was used to identify protein spots excised from 2D gels.

Table 6 Protein spots detected as changing by DeCyder analysis, in HL6O cells in response to YTX or dsYTX. The numbers in brackets are the number of protein spots which match the fold and p-value criteria when the FDR filter was not applied.

\begin{tabular}{|c|c|c|c|c|c|c|c|}
\hline & \multicolumn{7}{|c|}{ Comparison of change } \\
\hline & \multicolumn{2}{|c|}{ YTX/MeOH } & \multicolumn{2}{|c|}{ dsYTX/MeOH } & \multicolumn{2}{|c|}{ dsYTX/YTX } & \multirow[b]{2}{*}{$\begin{array}{l}\text { Total } \\
\text { spots }\end{array}$} \\
\hline & $\begin{array}{c}\geq 1.5 \text {-fold } \\
p \leq 0.05\end{array}$ & $\begin{array}{l}\geq 2 \text {-fold } \\
p \leq 0.01\end{array}$ & $\begin{array}{c}\geq 1.5 \text {-fold } \\
p \leq 0.05\end{array}$ & $\begin{array}{l}\geq 2 \text {-fold } \\
p \leq 0.01\end{array}$ & $\begin{array}{c}\geq 1.5 \text {-fold } \\
p \leq 0.05\end{array}$ & $\begin{array}{l}\geq 2 \text {-fold } \\
p \leq 0.01\end{array}$ & \\
\hline $\mathrm{pH} \mathrm{4-7}$ & $2(51)$ & $1(16)$ & $61(86)$ & $0(26)$ & $0(6)$ & $0(0)$ & 2413 \\
\hline $\mathrm{pH} \mathrm{6-11}$ & $0(12)$ & $0(0)$ & $0(22)$ & $0(6)$ & $0(2)$ & $0(0)$ & 2439 \\
\hline
\end{tabular}


2D-DIGE analysis detected a total of 119 protein spots undergoing a change in abundance by comparing all conditions (when the FDR filter was not applied). Thirtyeight protein spots were identified as changing significantly ( $\geq 2$-fold, $p \leq 0.01$ ) when comparing toxin treated cells to controls. Ten protein spots showed significant changes in abundance in response to both toxins, six changed only in YTX treated cells and 22 changed in cells treated with dsYTX. Of the six significant YTX specific changes, four were also possibly changing in response to dsYTX ( $\geq 1.5$-fold (but less than 2$), p \leq$ 0.05). Of the 22 dsYTX specific changes, 13 were also possibly changing with YTX. Potential changes ( $\geq 1.5$-fold (but less than 2 -fold), $p \leq 0.05$ ) were also detected in an additional 80 proteins. Eight were specific to YTX, 46 were specific to dsYTX and 26 were detected in both. Figure 14 shows the location of protein spots identified by DIGE analysis as undergoing a change in abundance, on pH 4-7 and 6-11 Coomassie stained polyacrylamide gels. Figures 15 and 16 summarise protein changes in response to toxin treatment (when the FDR filter was not or was applied, respectively). 


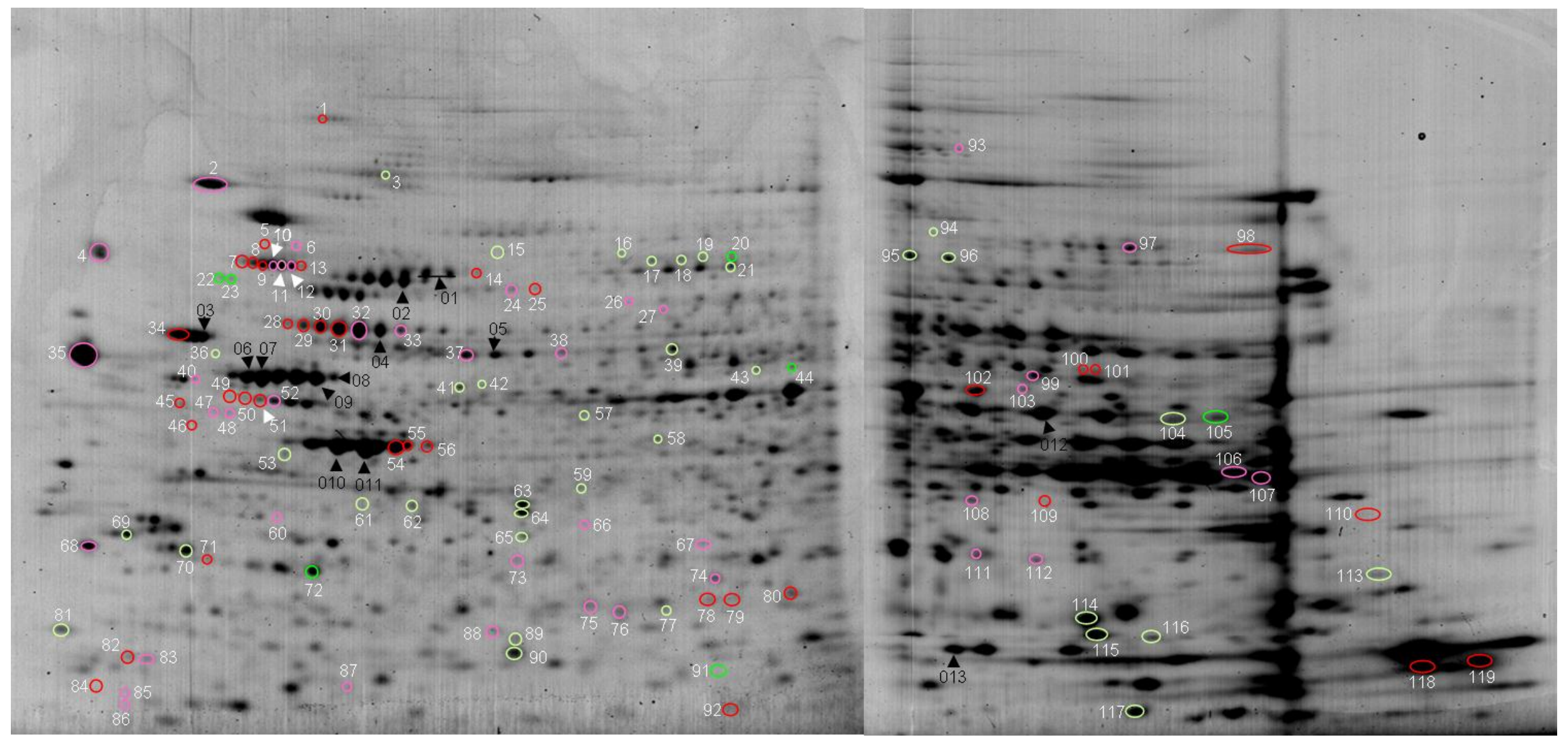

Figure 14 Coomassie blue stained gel with protein spots of interest from HL60 cells treated with YTX or dsTYX. Black numbers are protein spots which did not undergo a change of abundance in response to toxin treatment but were extracted and successfully identified by MALDI analysis. Red represents increase in abundance of at least 2 fold, $p \leq 0.01$. Pink represents an increase in abundance of between 1.5 and 2 -fold, $p \leq 0.05$. Green represents a decrease in abundance of at least 2 -fold, $p \leq 0.01$. Pale green represents a decrease in abundance between 1.5 and 2 -fold, $p \leq 0.05$. 


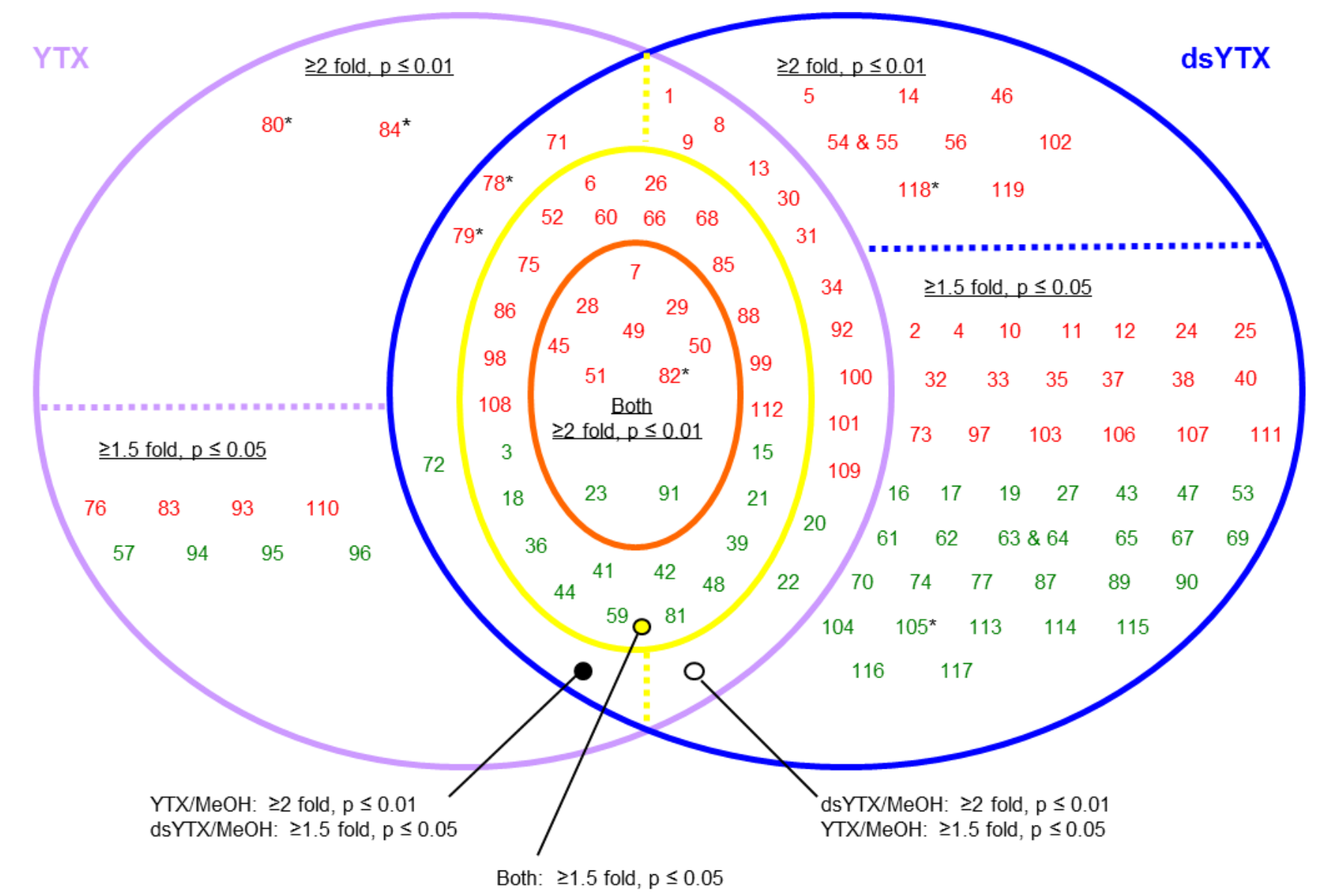

Figure 15 Distribution of protein changes detected by 2D DIGE for toxin vs. methanol when the FDR was not applied. Red numbers are those that underwent an increase in abundance in response to toxin. Green numbers are those proteins whose abundance decreased in response to toxin. Proteins almost always responded in the same direction in response to either YTX or dsYTX. The one exception to this is spot number 58. * Denotes proteins which also showed a difference in abundance in dsYTX treated cells compared to YTX. Numbers 1-92 are proteins in the $\mathrm{pH} 4-7$ range. Numbers $93-119$ are proteins in the $\mathrm{pH}$ 6-11 range. 


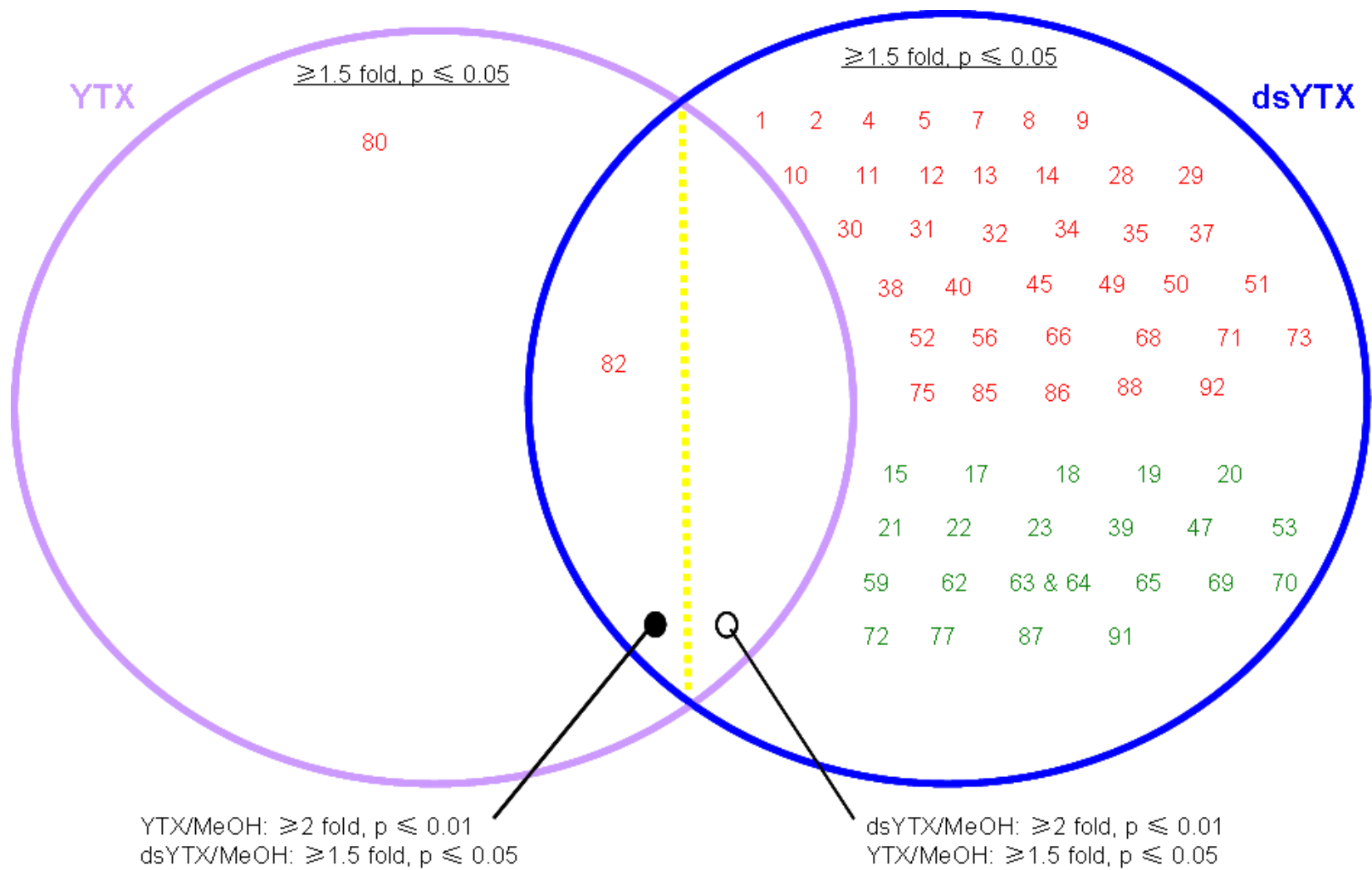

Figure 16 Distribution of protein changes detected by 2D DIGE for toxin vs. methanol when the FDR was applied. Red numbers are those that underwent an increase in abundance in response to toxin. Green numbers are those proteins whose abundance decreased in response to toxin. Numbers 1-92 are proteins in the $\mathrm{pH}$ 4-7 range. Numbers 93-119 are proteins in the $\mathrm{pH}$ 6-11 range. 
Protein spots which changed in response to both toxins seemed to be affected similarly by YTX and dsYTX. In almost all such cases a protein which had an increased abundance in YTX treated cells also had an increased abundance in dsYTX treated cells and vice versa. Of the 53 proteins with at least a 1.5-fold change in abundance ( $p \leq$ $0.05), 36$ showed similar fold changes with either toxin. Seventeen changed at least 2fold ( $p \leq 0.01$ ) with only one toxin, while changing between 1.5 and 2 -fold with the other toxin.

The only exception to proteins being affected in the same way was protein spot 58 . Although neither toxin caused a change in abundance meeting the required cut off criteria ( $\geq 1.5$-fold, $p \leq 0.05$ ), a possible decrease was detected in dsYTX treated cells compared to those treated with YTX $(-1.65$ fold, $t=0.0016)$. YTX caused an apparent increase of 1.49 fold $(t=0.033)$. DsYTX did not cause a change in abundance $(-1.11$ fold compared to methanol control, $t=0.54)$.

When the FDR filter was applied (Fig. 16) 62 protein spots were identified as potentially changing. The majority (60 spots) of these were at the $p \leq 0.05$ level only, and in response to dsYTX (59 spots). Protein spot 82 had a significant change in abundance ( $\geq 2$-fold, $p \leq 0.01$ ) in response to YTX treatment but only reached the $p \leq$ 0.05 level for dsYTX treatment.

\subsubsection{Protein identification by peptide mass fingerprinting}

Sixty-four of the 119 protein spots identified as changing by 2D-DIGE analysis were extracted from gels for identification by MALDI-TOF/TOF for peptide mass fingerprinting. Thirteen of these were successfully identified with a significant score at the $p \leq 0.05$ level. An additional 13 protein spots which showed no change in abundance were also identified. Tables 7 and 8 list the results of the DIGE analysis and the identity of the protein spots.

Four identified proteins were similarly affected by YTX and dsYTX in HL60 cells. Stress response proteins GRP78 (BiP) precursor and HSP60 (chaperonin) showed significant increases in abundance in dsYTX treated cells (approximately 2 and 2.5 fold 
respectively, $p \leq 0.01$, Table 7). However when the FDR filter was applied they only reached the $p \leq 0.05$ level. An apparent increase was seen in these proteins in YTX treated cells, but did not reach the 2-fold criterion for significance. The mitochondrial glycoprotein p32/tat-associated protein (chain A) and protein disulfide isomerase related protein 5 showed apparent changes in both YTX and dsYTX treated HL60, but these did not make the criteria for significance ( $\geq 2$-fold, $p \leq 0.01$ ). When the FDR filter was applied, both of the detected changes remained at the $\geq 1.5$-fold, $p \leq 0.05$ level.

Actin, hnRNP A, and BiP all appeared to have increased abundances in dsYTX treated HL60 cells, with actin having a significant increase (Table 7). These proteins all decreased in abundance in YTX treated HepG2 cells (Fig. 17, Young et al., 2009). No identified proteins showed changes in abundance in both YTX treated HL60 and HepG2 cells.

Spots number 2 and 106 showed a possible increase in abundance when treated with dsYTX compared to controls. These were identified as tumour rejection antigen (gp96) 1 and nucleolin, respectively (Table 7). The levels of the gp96 precursor have been shown to be affected by YTX in HepG2 cells (Young et al., 2009). Application of the FDR filter resulted in the change detected in nucleolin no longer reaching the $p$-value cut-off criteria. The gp96 precursor change still met the $\geq 1.5$-fold, $p \leq 0.05$ cut-off.

Spot 96 showed an apparent decrease in HL60 cells treated with YTX. This was matched by MASCOT to an unnamed protein, containing a K-homology domain (type 1). This domain is found in a range of proteins of the ribosome and in transcription factors. A BLAST search of the top ranked protein match indicated that this protein may be the far upstream element binding protein 1 (Supplementary Data CD). This protein is involved in c-myc expression. C-myc was one of the predicted hub molecules identified in the pathway affected by Pel A in HL60 cells detected by IPA.

No identified proteins were changing in common between HL60 cells treated with YTX, Pel A, or PTX (Fig. 18). Actin and possibly tumour rejection antigen 1 increased in abundance in HL60 cells treated with dsYTX or Pel A (Fig. 19). BiP appeared to increase in abundance in dsYTX and Pel A treated cells. In PTX treated HL60 cells and YTX treated HepG2 cells however it decreased (Wilmes et al., 2012; Young et al., 2009). 
HnRNP A showed an apparent increase in response to dsYTX. It was also found to increase in Pel A or PTX treated HL60 cells (Wilmes et al., 2011, 2012). In YTX treated HepG2 cells however it was shown to decrease (Young et al., 2009).

Spot 82 still met the criteria for a significant change in abundance in response to YTX compared with controls, when the FDR filter was applied. The top-ranked match for this protein was the signal recognition particle; however the identification did not have a significant Mascot score.

A total of 288 spots were picked from HL60 gels. Twenty-four of these were identified with a significant Mascot score. Thirty-one had MS spectra of comparable quality to those that were identified, but did not provide a significant match. 
Table 7 HL60 Protein abundance change (Av. Ratio) and associated statistics acquired from DeCyder and protein identification where applicable of proteins of interest and picked protein spots as numbered in Figs. 14-16. N/A for the protein name indicates that a protein spot was not selected for identification due to low abundance. An absence of DeCyder statistics is indicative that a protein spot was not present in all protein spot maps. Av. Ratio is the protein volume of the first condition compared to the second in the comparison. For example negative value when comparing dsYTX/untreated means that the protein has undergone a decrease in abundance in response to dsYTX respective to the untreated control. * Indicates protein identification is not the top-ranked match.

\begin{tabular}{|c|c|c|c|c|c|c|}
\hline Spot \# & pH & Comparison & T-test & $\begin{array}{l}\text { Av. } \\
\text { Ratio }\end{array}$ & $\begin{array}{l}\text { 1-way } \\
\text { ANOVA }\end{array}$ & Name \\
\hline \multirow{3}{*}{1} & \multirow{3}{*}{$4-7$} & $\mathrm{YTX} / \mathrm{MeOH}$ & $9.50 \mathrm{E}-05$ & 1.87 & $2.20 \mathrm{E}-05$ & \multirow{3}{*}{$\begin{array}{l}\text { Immunoglobulin heavy chain variable region } \\
\text { (protein identification score was not significant) }\end{array}$} \\
\hline & & dsYTX/MeOH & 0.00056 & 2.13 & 2.20E-05 & \\
\hline & & dsYTX/YTX & 0.11 & 1.14 & $2.20 \mathrm{E}-05$ & \\
\hline \multirow{3}{*}{2} & \multirow{3}{*}{$4-7$} & $\mathrm{YTX} / \mathrm{MeOH}$ & 0.063 & 1.27 & 0.0014 & \multirow{3}{*}{ tumour rejection antigen (gp96) 1} \\
\hline & & dsYTX/MeOH & 0.00047 & 1.63 & 0.0014 & \\
\hline & & dsYTX/YTX & 0.033 & 1.28 & 0.0014 & \\
\hline \multirow{3}{*}{3} & \multirow{3}{*}{$4-7$} & $\mathrm{YTX} / \mathrm{MeOH}$ & 0.0089 & -1.74 & 0.0049 & \multirow{3}{*}{$N / A$} \\
\hline & & dsYTX/MeOH & 0.01 & -1.89 & 0.0049 & \\
\hline & & dsYTX/YTX & 0.58 & -1.08 & 0.0049 & \\
\hline \multirow{3}{*}{4} & \multirow{3}{*}{$4-7$} & $\mathrm{YTX} / \mathrm{MeOH}$ & 0.019 & 1.4 & 0.003 & \multirow{3}{*}{$\begin{array}{l}\text { opioid growth factor receptor and/or S100 calcium-binding protein A8 } \\
\text { (protein identification score was not significant) }\end{array}$} \\
\hline & & dsYTX/MeOH & 0.0053 & 1.55 & 0.003 & \\
\hline & & dsYTX/YTX & 0.21 & 1.1 & 0.003 & \\
\hline \multirow{3}{*}{5} & \multirow{3}{*}{$4-7$} & $\mathrm{YTX} / \mathrm{MeOH}$ & 0.081 & 1.61 & 0.0089 & \multirow{3}{*}{$\begin{array}{l}\text { MHC class I antigen } \\
\text { (protein identification score was not significant) }\end{array}$} \\
\hline & & dsYTX/MeOH & 0.00051 & 2.02 & 0.0089 & \\
\hline & & dsYTX/YTX & 0.21 & 1.26 & 0.0089 & \\
\hline \multirow{3}{*}{6} & \multirow{3}{*}{$4-7$} & YTX/MeOH & 0.018 & 1.5 & 0.0046 & \multirow{3}{*}{$N / A$} \\
\hline & & dsYTX/MeOH & 0.013 & 1.65 & 0.0046 & \\
\hline & & dsYTX/YTX & 0.23 & 1.1 & 0.0046 & \\
\hline \multirow{3}{*}{7} & \multirow{3}{*}{$4-7$} & YTX/MeOH & 0.001 & 2.37 & 8.30E-05 & \multirow{3}{*}{$\begin{array}{c}\text { hCG2015481 } \\
\text { (protein identification score was not significant) }\end{array}$} \\
\hline & & dsYTX/MeOH & 0.00017 & 2.9 & $8.30 \mathrm{E}-05$ & \\
\hline & & dsYTX/YTX & 0.21 & 1.22 & 8.30E-05 & \\
\hline
\end{tabular}




\begin{tabular}{|c|c|c|c|c|c|c|}
\hline Spot \# & $\mathrm{pH}$ & Comparison & T-test & $\begin{array}{c}\text { Av. } \\
\text { Ratio }\end{array}$ & $\begin{array}{l}\text { 1-way } \\
\text { ANOVA }\end{array}$ & Name \\
\hline \multirow{3}{*}{8} & \multirow{3}{*}{$4-7$} & YTX/MeOH & 0.0023 & 1.88 & 0.00019 & \multirow{3}{*}{$\begin{array}{c}\text { hCG2044129 } \\
\text { (protein identification score was not significant) }\end{array}$} \\
\hline & & dsYTX/MeOH & 0.00064 & 2.31 & 0.00019 & \\
\hline & & dsYTX/YTX & 0.12 & 1.23 & 0.00019 & \\
\hline \multirow{3}{*}{9} & \multirow{3}{*}{$4-7$} & YTX/MeOH & 0.0044 & 1.65 & 0.00018 & \multirow{9}{*}{ GRP78 precursor } \\
\hline & & dsYTX/MeOH & 0.00046 & 2.07 & 0.00018 & \\
\hline & & dsYTX/YTX & 0.045 & 1.25 & 0.00018 & \\
\hline \multirow{3}{*}{10} & \multirow{3}{*}{$4-7$} & YTX/MeOH & 0.013 & 1.49 & 0.0006 & \\
\hline & & dsYTX/MeOH & 0.00061 & 1.82 & 0.0006 & \\
\hline & & dsYTX/YTX & 0.064 & 1.22 & 0.0006 & \\
\hline \multirow{3}{*}{11} & \multirow{3}{*}{$4-7$} & YTX/MeOH & 0.043 & 1.44 & 0.0042 & \\
\hline & & dsYTX/MeOH & 0.002 & 1.7 & 0.0042 & \\
\hline & & dsYTX/YTX & 0.15 & 1.18 & 0.0042 & \\
\hline \multirow{3}{*}{12} & \multirow{3}{*}{$4-7$} & YTX/MeOH & 0.054 & 1.54 & 0.0096 & \multirow{3}{*}{ BiP protein } \\
\hline & & dsYTX/MeOH & 0.0033 & 1.8 & 0.0096 & \\
\hline & & dsYTX/YTX & 0.28 & 1.17 & 0.0096 & \\
\hline \multirow{3}{*}{13} & \multirow{3}{*}{$4-7$} & YTX/MeOH & 0.022 & 1.99 & 0.0032 & \multirow{3}{*}{$\begin{array}{c}\text { PRO1095 } \\
\text { (protein identification score was not significant) }\end{array}$} \\
\hline & & dsYTX/MeOH & 0.0038 & 2.57 & 0.0032 & \\
\hline & & dsYTX/YTX & 0.18 & 1.3 & 0.0032 & \\
\hline \multirow{3}{*}{14} & \multirow{3}{*}{$4-7$} & YTX/MeOH & 0.11 & 1.58 & 0.021 & \multirow{3}{*}{$N / A$} \\
\hline & & dsYTX/MeOH & 0.0046 & 2.01 & 0.021 & \\
\hline & & dsYTX/YTX & 0.24 & 1.28 & 0.021 & \\
\hline \multirow{3}{*}{15} & \multirow{3}{*}{$4-7$} & YTX/MeOH & 0.001 & -1.76 & 0.001 & \multirow{3}{*}{$N / A$} \\
\hline & & dsYTX/MeOH & 0.0062 & -1.71 & 0.001 & \\
\hline & & dsYTX/YTX & 0.87 & 1.03 & 0.001 & \\
\hline \multirow{3}{*}{16} & \multirow{3}{*}{$4-7$} & YTX/MeOH & 0.18 & -1.23 & 0.015 & \multirow{3}{*}{$N / A$} \\
\hline & & dsYTX/MeOH & 0.017 & -1.61 & 0.015 & \\
\hline & & dsYTX/YTX & 0.043 & -1.3 & 0.015 & \\
\hline
\end{tabular}




\begin{tabular}{|c|c|c|c|c|c|c|}
\hline Spot \# & pH & Comparison & T-test & $\begin{array}{l}\text { Av. } \\
\text { Ratio }\end{array}$ & $\begin{array}{l}\text { 1-way } \\
\text { ANOVA }\end{array}$ & Name \\
\hline \multirow{3}{*}{17} & \multirow{3}{*}{$4-7$} & $\mathrm{YTX} / \mathrm{MeOH}$ & 0.044 & -1.41 & 0.0078 & \multirow{3}{*}{$N / A$} \\
\hline & & dsYTX/MeOH & 0.0069 & -1.66 & 0.0078 & \\
\hline & & dsYTX/YTX & 0.18 & -1.18 & 0.0078 & \\
\hline \multirow{3}{*}{18} & \multirow{3}{*}{$4-7$} & $\mathrm{YTX} / \mathrm{MeOH}$ & 0.0038 & -1.62 & 0.00071 & \multirow{3}{*}{$\begin{array}{l}\text { Unnamed protein product (highly similar to absent in melanoma } 1 \text { protein) } \\
\text { (protein identification score was not significant) }\end{array}$} \\
\hline & & dsYTX/MeOH & 0.0024 & -1.95 & 0.00071 & \\
\hline & & dsYTX/YTX & 0.11 & -1.2 & 0.00071 & \\
\hline \multirow{3}{*}{19} & \multirow{3}{*}{$4-7$} & YTX/MeOH & 0.034 & -1.37 & 0.0029 & \multirow{3}{*}{$\begin{array}{c}\text { unnamed protein product \{contains Ribosomal L3 superfamily domain; highly similar to } \\
\text { mitochondrial 39s ribosomal protein L3\} } \\
\text { (protein identification score was not significant) }\end{array}$} \\
\hline & & dsYTX/MeOH & 0.006 & -1.7 & 0.0029 & \\
\hline & & dsYTX/YTX & 0.034 & -1.24 & 0.0029 & \\
\hline \multirow{3}{*}{20} & \multirow{3}{*}{$4-7$} & YTX/MeOH & 0.0033 & -1.63 & 0.00027 & \multirow{3}{*}{$\begin{array}{c}\text { hCG2040114, isoform CRA_b } \\
\text { (protein identification score was not significant) }\end{array}$} \\
\hline & & dsYTX/MeOH & 0.0012 & -2.04 & 0.00027 & \\
\hline & & dsYTX/YTX & 0.043 & -1.25 & 0.00027 & \\
\hline \multirow{3}{*}{21} & \multirow{3}{*}{$4-7$} & YTX/MeOH & 0.003 & -1.59 & 0.00029 & \multirow{3}{*}{$\begin{array}{c}\text { hCG2042223 } \\
\text { (protein identification score was not significant) }\end{array}$} \\
\hline & & dsYTX/MeOH & 0.00029 & -1.63 & 0.00029 & \\
\hline & & dsYTX/YTX & 0.86 & -1.02 & 0.00029 & \\
\hline \multirow{3}{*}{22} & \multirow{3}{*}{$4-7$} & YTX/MeOH & 0.014 & -2.81 & 0.0019 & \multirow{3}{*}{$\begin{array}{l}\text { translation initiation factor elF-4gamma } \\
\text { (protein identification score was not significant) }\end{array}$} \\
\hline & & dsYTX/MeOH & 0.0061 & -2.58 & 0.0019 & \\
\hline & & dsYTX/YTX & 0.36 & 1.09 & 0.0019 & \\
\hline \multirow{3}{*}{23} & \multirow{3}{*}{$4-7$} & YTX/MeOH & 0.0013 & -2.68 & 0.00015 & \multirow{3}{*}{$\begin{array}{l}\text { cytotoxic T-lymphocyte-associated protein } 4 \\
\text { (protein identification score was not significant) }\end{array}$} \\
\hline & & dsYTX/MeOH & 0.00037 & -2.55 & 0.00015 & \\
\hline & & dsYTX/YTX & 0.63 & 1.05 & 0.00015 & \\
\hline \multirow{3}{*}{24} & \multirow{3}{*}{$4-7$} & $\mathrm{YTX} / \mathrm{MeOH}$ & 0.12 & 1.49 & 0.026 & \multirow{3}{*}{$\begin{array}{l}\text { ferritin light polypeptide } \\
\text { (protein identification score was not significant) }\end{array}$} \\
\hline & & dsYTX/MeOH & 0.015 & 2.1 & 0.026 & \\
\hline & & dsYTX/YTX & 0.18 & 1.41 & 0.026 & \\
\hline \multirow{3}{*}{25} & \multirow{3}{*}{$4-7$} & $\mathrm{YTX} / \mathrm{MeOH}$ & 0.056 & 1.65 & 0.007 & \multirow{3}{*}{$\begin{array}{l}\text { immunoglobulin lambda chain variable region } \\
\text { (protein identification score was not significant) }\end{array}$} \\
\hline & & dsYTX/MeOH & 0.0046 & 2.38 & 0.007 & \\
\hline & & dsYTX/YTX & 0.12 & 1.44 & 0.007 & \\
\hline
\end{tabular}




\begin{tabular}{|c|c|c|c|c|c|c|}
\hline Spot \# & $\mathrm{pH}$ & Comparison & T-test & $\begin{array}{c}\text { Av. } \\
\text { Ratio }\end{array}$ & $\begin{array}{l}\text { 1-way } \\
\text { ANOVA }\end{array}$ & Name \\
\hline \multirow{3}{*}{26} & \multirow{3}{*}{$4-7$} & $\mathrm{YTX} / \mathrm{MeOH}$ & 0.0075 & 1.76 & 0.0059 & \multirow{3}{*}{$N / A$} \\
\hline & & dsYTX/MeOH & 0.0093 & 1.67 & 0.0059 & \\
\hline & & dsYTX/YTX & 0.74 & -1.06 & 0.0059 & \\
\hline \multirow{3}{*}{27} & \multirow{3}{*}{$4-7$} & YTX/MeOH & 0.012 & -1.45 & 0.0083 & \multirow{3}{*}{$N / A$} \\
\hline & & dsYTX/MeOH & 0.014 & -1.54 & 0.0083 & \\
\hline & & dsYTX/YTX & 0.53 & -1.07 & 0.0083 & \\
\hline \multirow{3}{*}{28} & \multirow{3}{*}{$4-7$} & YTX/MeOH & 0.00038 & 2.05 & 4.20E-05 & \multirow{3}{*}{$\begin{array}{c}\text { hCG2012006 } \\
\text { (protein identification score was not significant) }\end{array}$} \\
\hline & & dsYTX/MeOH & 0.00026 & 2.55 & 4.20E-05 & \\
\hline & & dsYTX/YTX & 0.11 & 1.24 & $4.20 \mathrm{E}-05$ & \\
\hline \multirow{3}{*}{29} & \multirow{3}{*}{$4-7$} & YTX/MeOH & 0.0012 & 2.12 & $6.20 \mathrm{E}-05$ & \multirow{3}{*}{$\begin{array}{l}\text { heat shock } 60 \mathrm{kDa} \text { protein } 1 \text { (chaperonin), isoform CRA_c } \\
\text { (protein identification score was not significant) }\end{array}$} \\
\hline & & dsYTX/MeOH & 0.0004 & 2.89 & $6.20 \mathrm{E}-05$ & \\
\hline & & dsYTX/YTX & 0.037 & 1.36 & $6.20 \mathrm{E}-05$ & \\
\hline \multirow{3}{*}{30} & \multirow{3}{*}{$4-7$} & $\mathrm{YTX} / \mathrm{MeOH}$ & 0.0034 & 1.86 & $9.30 \mathrm{E}-05$ & \multirow{3}{*}{ heat shock 60kDa protein 1 (chaperonin), isoform CRA_c } \\
\hline & & dsYTX/MeOH & 0.00032 & 2.54 & 9.30E-05 & \\
\hline & & dsYTX/YTX & 0.021 & 1.37 & 9.30E-05 & \\
\hline \multirow{3}{*}{31} & \multirow{3}{*}{$4-7$} & $\mathrm{YTX} / \mathrm{MeOH}$ & 0.03 & 1.53 & 0.0014 & \multirow{3}{*}{$\begin{array}{l}\text { immunoglobulin heavy chain variable region } \\
\text { (protein identification score was not significant) }\end{array}$} \\
\hline & & dsYTX/MeOH & 0.00093 & 2 & 0.0014 & \\
\hline & & dsYTX/YTX & 0.056 & 1.31 & 0.0014 & \\
\hline \multirow{3}{*}{32} & \multirow{3}{*}{$4-7$} & $\mathrm{YTX} / \mathrm{MeOH}$ & 0.3 & 1.22 & 0.026 & \multirow{3}{*}{$\begin{array}{l}\text { unnamed protein product \{GroEL/chaperonin type I/II/chaperonin like domain.\} } \\
\text { (protein identification score was not significant) }\end{array}$} \\
\hline & & dsYTX/MeOH & 0.0028 & 1.57 & 0.026 & \\
\hline & & dsYTX/YTX & 0.12 & 1.28 & 0.026 & \\
\hline \multirow{3}{*}{33} & \multirow{3}{*}{$4-7$} & $\mathrm{YTX} / \mathrm{MeOH}$ & 0.22 & 1.23 & 0.049 & \multirow{3}{*}{$N / A$} \\
\hline & & dsYTX/MeOH & 0.0092 & 1.51 & 0.049 & \\
\hline & & dsYTX/YTX & 0.23 & 1.23 & 0.049 & \\
\hline \multirow{3}{*}{34} & \multirow{3}{*}{$4-7$} & $\mathrm{YTX} / \mathrm{MeOH}$ & 0.0031 & 1.75 & 0.00021 & \multirow{3}{*}{$\begin{array}{c}\text { hCG2030305, isoform CRA_a } \\
\text { (protein identification score was not significant) }\end{array}$} \\
\hline & & dsYTX/MeOH & 0.00074 & 2.1 & 0.00021 & \\
\hline & & dsYTX/YTX & 0.093 & 1.2 & 0.00021 & \\
\hline
\end{tabular}




\begin{tabular}{|c|c|c|c|c|c|c|}
\hline Spot \# & $\mathrm{pH}$ & Comparison & T-test & $\begin{array}{c}\text { Av. } \\
\text { Ratio }\end{array}$ & $\begin{array}{l}\text { 1-way } \\
\text { ANOVA }\end{array}$ & Name \\
\hline \multirow{3}{*}{35} & \multirow{3}{*}{$4-7$} & $\mathrm{YTX} / \mathrm{MeOH}$ & 0.096 & 1.31 & 0.01 & \multirow{3}{*}{$\begin{array}{l}\text { calreticulin precursor variant } \\
\text { (protein identification score was not significant) }\end{array}$} \\
\hline & & dsYTX/MeOH & 0.0062 & 1.56 & 0.01 & \\
\hline & & dsYTX/YTX & 0.095 & 1.19 & 0.01 & \\
\hline \multirow{3}{*}{36} & \multirow{3}{*}{$4-7$} & $\mathrm{YTX} / \mathrm{MeOH}$ & 0.034 & -1.72 & 0.037 & \multirow{3}{*}{$N / A$} \\
\hline & & dsYTX/MeOH & 0.031 & -1.62 & 0.037 & \\
\hline & & dsYTX/YTX & 0.7 & 1.06 & 0.037 & \\
\hline \multirow{3}{*}{37} & \multirow{3}{*}{$4-7$} & YTX/MeOH & 0.045 & 1.39 & 0.0068 & \multirow{3}{*}{$N / A$} \\
\hline & & dsYTX/MeOH & 0.0062 & 1.58 & 0.0068 & \\
\hline & & dsYTX/YTX & 0.18 & 1.14 & 0.0068 & \\
\hline \multirow{3}{*}{38} & \multirow{3}{*}{ 4-7 } & YTX/MeOH & 0.13 & 1.34 & 0.0083 & \multirow{3}{*}{$N / A$} \\
\hline & & dsYTX/MeOH & 0.00089 & 1.77 & 0.0083 & \\
\hline & & dsYTX/YTX & 0.1 & 1.32 & 0.0083 & \\
\hline \multirow{3}{*}{39} & \multirow{3}{*}{$4-7$} & YTX/MeOH & 0.012 & -1.76 & 0.0065 & \multirow{3}{*}{$\begin{array}{c}\text { NOS1 protein } \\
\text { (protein identification score was not significant) }\end{array}$} \\
\hline & & dsYTX/MeOH & 0.0017 & -1.79 & 0.0065 & \\
\hline & & dsYTX/YTX & 0.98 & -1.02 & 0.0065 & \\
\hline \multirow{3}{*}{40} & \multirow{3}{*}{$4-7$} & YTX/MeOH & 0.051 & 1.56 & 0.0095 & \multirow{3}{*}{$N / A$} \\
\hline & & dsYTX/MeOH & 0.0009 & 1.8 & 0.0095 & \\
\hline & & dsYTX/YTX & 0.34 & 1.16 & 0.0095 & \\
\hline \multirow{3}{*}{41} & \multirow{3}{*}{$4-7$} & YTX/MeOH & 0.029 & -1.57 & 0.014 & \multirow{3}{*}{$\begin{array}{c}\text { unnamed protein product \{non-specific BLAST hit to NAD-dependent glycerol-3- } \\
\text { phosphate dehydrogenase C-terminus domain\} } \\
\text { (protein identification score was not significant) }\end{array}$} \\
\hline & & dsYTX/MeOH & 0.013 & -1.77 & 0.014 & \\
\hline & & dsYTX/YTX & 0.45 & -1.13 & 0.014 & \\
\hline \multirow{3}{*}{42} & \multirow{3}{*}{$4-7$} & $\mathrm{YTX} / \mathrm{MeOH}$ & 0.046 & -1.5 & 0.0085 & \multirow{3}{*}{$N / A$} \\
\hline & & dsYTX/MeOH & 0.01 & -1.8 & 0.0085 & \\
\hline & & dsYTX/YTX & 0.14 & -1.2 & 0.0085 & \\
\hline \multirow{3}{*}{43} & \multirow{3}{*}{$4-7$} & YTX/MeOH & 0.059 & -1.57 & 0.042 & \multirow{3}{*}{$N / A$} \\
\hline & & dsYTX/MeOH & 0.034 & -1.79 & 0.042 & \\
\hline & & dsYTX/YTX & 0.49 & -1.14 & 0.042 & \\
\hline
\end{tabular}




\begin{tabular}{|c|c|c|c|c|c|c|}
\hline Spot \# & pH & Comparison & T-test & $\begin{array}{c}\text { Av. } \\
\text { Ratio }\end{array}$ & $\begin{array}{l}\text { 1-way } \\
\text { ANOVA }\end{array}$ & Name \\
\hline \multirow{3}{*}{44} & \multirow{3}{*}{$4-7$} & $\mathrm{YTX} / \mathrm{MeOH}$ & 0.025 & -2 & 0.018 & \multirow{3}{*}{$N / A$} \\
\hline & & dsYTX/MeOH & 0.02 & -1.96 & 0.018 & \\
\hline & & dsYTX/YTX & 0.86 & 1.02 & 0.018 & \\
\hline \multirow{3}{*}{45} & \multirow{3}{*}{$4-7$} & YTX/MeOH & 0.0018 & 2.02 & $3.20 \mathrm{E}-05$ & \multirow{3}{*}{$\begin{array}{l}\text { KRT8 protein } \\
\text { (protein identification score was not significant) }\end{array}$} \\
\hline & & dsYTX/MeOH & 5.70E-05 & 2.81 & $3.20 \mathrm{E}-05$ & \\
\hline & & dsYTX/YTX & 0.026 & 1.39 & $3.20 \mathrm{E}-05$ & \\
\hline \multirow{3}{*}{46} & \multirow{3}{*}{$4-7$} & $\mathrm{YTX} / \mathrm{MeOH}$ & 0.052 & 2.34 & 0.0095 & \multirow{3}{*}{$\begin{array}{c}\text { zinc finger protein } 441 \\
\text { (protein identification score was not significant) }\end{array}$} \\
\hline & & dsYTX/MeOH & 0.0099 & 3.55 & 0.0095 & \\
\hline & & dsYTX/YTX & 0.16 & 1.51 & 0.0095 & \\
\hline \multirow{3}{*}{47} & \multirow{3}{*}{$4-7$} & $\mathrm{YTX} / \mathrm{MeOH}$ & 0.065 & -1.38 & 0.011 & \multirow{3}{*}{$N / A$} \\
\hline & & dsYTX/MeOH & 0.004 & -1.61 & 0.011 & \\
\hline & & dsYTX/YTX & 0.27 & -1.17 & 0.011 & \\
\hline \multirow{3}{*}{48} & \multirow{3}{*}{$4-7$} & $\mathrm{YTX} / \mathrm{MeOH}$ & 0.04 & -1.5 & 0.016 & \multirow{3}{*}{$N / A$} \\
\hline & & dsYTX/MeOH & 0.0094 & -1.55 & 0.016 & \\
\hline & & dsYTX/YTX & 0.88 & -1.04 & 0.016 & \\
\hline \multirow{3}{*}{49} & \multirow{3}{*}{$4-7$} & YTX/MeOH & 0.0029 & 2.45 & 0.00074 & \multirow{3}{*}{$N / A$} \\
\hline & & dsYTX/MeOH & 0.0004 & 2.16 & 0.00074 & \\
\hline & & dsYTX/YTX & 0.62 & -1.13 & 0.00074 & \\
\hline \multirow{3}{*}{50} & \multirow{3}{*}{$4-7$} & YTX/MeOH & 0.00097 & 2.53 & $8.50 \mathrm{E}-05$ & \multirow{3}{*}{$\begin{array}{c}\text { tyrosine hydroxylase } \\
\text { (protein identification score was not significant) }\end{array}$} \\
\hline & & dsYTX/MeOH & 0.00055 & 2.42 & $8.50 \mathrm{E}-05$ & \\
\hline & & dsYTX/YTX & 0.73 & -1.05 & $8.50 \mathrm{E}-05$ & \\
\hline \multirow{3}{*}{51} & \multirow{3}{*}{$4-7$} & YTX/MeOH & 0.0039 & 2.03 & 0.00052 & \multirow{3}{*}{$\begin{array}{l}\text { unnamed protein product\{nonspecific BLAST hit to BACK domain\} } \\
\text { (protein identification score was not significant) }\end{array}$} \\
\hline & & dsYTX/MeOH & 0.0021 & 2.03 & 0.00052 & \\
\hline & & dsYTX/YTX & 0.94 & -1 & 0.00052 & \\
\hline \multirow{3}{*}{52} & \multirow{3}{*}{$4-7$} & $\mathrm{YTX} / \mathrm{MeOH}$ & 0.024 & 1.62 & 0.0048 & \multirow{3}{*}{ protein disulfide isomerase-related protein 5} \\
\hline & & dsYTX/MeOH & 0.0072 & 1.73 & 0.0048 & \\
\hline & & dsYTX/YTX & 0.45 & 1.07 & 0.0048 & \\
\hline \multirow{3}{*}{53} & \multirow{3}{*}{$4-7$} & $\mathrm{YTX} / \mathrm{MeOH}$ & 0.095 & -1.28 & 0.0073 & \multirow{3}{*}{$N / A$} \\
\hline & & dsYTX/MeOH & 0.004 & -1.64 & 0.0073 & \\
\hline & & dsYTX/YTX & 0.077 & -1.28 & 0.0073 & \\
\hline
\end{tabular}




\begin{tabular}{|c|c|c|c|c|c|c|}
\hline Spot \# & $\mathrm{pH}$ & Comparison & T-test & $\begin{array}{c}\text { Av. } \\
\text { Ratio }\end{array}$ & $\begin{array}{c}\text { 1-way } \\
\text { ANOVA }\end{array}$ & Name \\
\hline \multirow{2}{*}{54} & \multirow{4}{*}{$4-7$} & $\mathrm{YTX} / \mathrm{MeOH}$ & 0.19 & 1.71 & 0.061 & \multirow{2}{*}{ unnamed protein product \{specific BLAST hit to actin\} } \\
\hline & & & & & & \\
\hline \multirow{2}{*}{55} & & & & & & \multirow{2}{*}{$\beta$-actin* } \\
\hline & & dsYTX/YTX & 0.33 & 1.32 & 0.061 & \\
\hline \multirow{3}{*}{56} & \multirow{3}{*}{$4-7$} & $\mathrm{YTX} / \mathrm{MeOH}$ & 0.21 & 2.12 & 0.049 & \multirow{3}{*}{$\begin{array}{l}\text { unnamed protein product \{specific hit to actin domain\} } \\
\text { (protein identification score was not significant) }\end{array}$} \\
\hline & & dsYTX/MeOH & 0.0061 & 3.19 & 0.049 & \\
\hline & & dsYTX/YTX & 0.27 & 1.51 & 0.049 & \\
\hline \multirow{3}{*}{57} & \multirow{3}{*}{$4-7$} & $\mathrm{YTX} / \mathrm{MeOH}$ & 0.0064 & -1.83 & 0.0053 & \multirow{3}{*}{$N / A$} \\
\hline & & dsYTX/MeOH & 0.046 & -1.46 & 0.0053 & \\
\hline & & dsYTX/YTX & 0.082 & 1.26 & 0.0053 & \\
\hline \multirow{3}{*}{58} & \multirow{3}{*}{$4-7$} & $\mathrm{YTX} / \mathrm{MeOH}$ & 0.033 & 1.49 & 0.0074 & \multirow{3}{*}{$N / A$} \\
\hline & & $\mathrm{dsYTX} / \mathrm{MeOH}$ & 0.54 & -1.11 & 0.0074 & \\
\hline & & dsYTX/YTX & 0.0016 & -1.65 & 0.0074 & \\
\hline \multirow{3}{*}{59} & \multirow{3}{*}{$4-7$} & $\mathrm{YTX} / \mathrm{MeOH}$ & 0.013 & -1.57 & 0.0036 & \multirow{3}{*}{$N / A$} \\
\hline & & dsYTX/MeOH & 0.0059 & -1.82 & 0.0036 & \\
\hline & & dsYTX/YTX & 0.25 & -1.16 & 0.0036 & \\
\hline \multirow{3}{*}{60} & \multirow{3}{*}{$4-7$} & YTX/MeOH & 0.03 & 1.54 & 0.012 & \multirow{3}{*}{$N / A$} \\
\hline & & dsYTX/MeOH & 0.0098 & 1.75 & 0.012 & \\
\hline & & dsYTX/YTX & 0.42 & 1.14 & 0.012 & \\
\hline \multirow{3}{*}{61} & \multirow{3}{*}{$4-7$} & YTX/MeOH & 0.09 & -1.4 & 0.044 & \multirow{3}{*}{$N / A$} \\
\hline & & dsYTX/MeOH & 0.034 & -1.68 & 0.044 & \\
\hline & & $\mathrm{dsYTX/YTX}$ & 0.31 & -1.19 & 0.044 & \\
\hline \multirow{3}{*}{62} & \multirow{3}{*}{$4-7$} & YTX/MeOH & 0.022 & -1.26 & 0.00018 & \multirow{3}{*}{$N / A$} \\
\hline & & dsYTX/MeOH & 0.00044 & -1.56 & 0.00018 & \\
\hline & & dsYTX/YTX & 0.0017 & -1.24 & 0.00018 & \\
\hline
\end{tabular}




\begin{tabular}{|c|c|c|c|c|c|c|}
\hline Spot \# & pH & Comparison & T-test & $\begin{array}{c}\text { Av. } \\
\text { Ratio }\end{array}$ & $\begin{array}{l}\text { 1-way } \\
\text { ANOVA }\end{array}$ & Name \\
\hline 63 & \multirow{3}{*}{$4-7$} & YTX/MeOH & 0.092 & -1.32 & 0.033 & $\begin{array}{c}\text { zinc finger protein } 441 \\
\text { (protein identification score was not significant) }\end{array}$ \\
\hline \multirow{2}{*}{64} & & dsYTX/MeOH & 0.0042 & -1.56 & 0.033 & \multirow{2}{*}{$\begin{array}{c}\text { tyrosine hydroxylase } \\
\text { (protein identification score was not significant) }\end{array}$} \\
\hline & & dsYTX/YTX & 0.42 & -1.18 & 0.033 & \\
\hline \multirow{6}{*}{65} & \multirow{6}{*}{$4-7$} & YTX/MeOH & 0.0096 & -1.41 & 0.002 & \multirow{6}{*}{$\begin{array}{l}\text { immunoglobulin heavy chain variable region } \\
\text { (protein identification score was not significant) }\end{array}$} \\
\hline & & dsYTX/MeOH & 0.0017 & -1.59 & 0.002 & \\
\hline & & dsYTX/YTX & 0.27 & -1.13 & 0.002 & \\
\hline & & YTX/MeOH & 0.084 & -1.24 & 0.02 & \\
\hline & & dsYTX/MeOH & 0.02 & -1.38 & 0.02 & \\
\hline & & dsYTX/YTX & 0.15 & -1.12 & 0.02 & \\
\hline \multirow{3}{*}{66} & \multirow{3}{*}{$4-7$} & YTX/MeOH & 0.0038 & 1.76 & 0.002 & \multirow{3}{*}{$N / A$} \\
\hline & & dsYTX/MeOH & 0.0072 & 1.92 & 0.002 & \\
\hline & & dsYTX/YTX & 0.58 & 1.09 & 0.002 & \\
\hline \multirow{3}{*}{67} & \multirow{3}{*}{$4-7$} & YTX/MeOH & 0.052 & -1.41 & 0.021 & \multirow[t]{3}{*}{$N / A$} \\
\hline & & dsYTX/MeOH & 0.008 & -1.51 & 0.021 & \\
\hline & & dsYTX/YTX & 0.67 & -1.07 & 0.021 & \\
\hline \multirow{3}{*}{68} & \multirow{3}{*}{$4-7$} & YTX/MeOH & 0.027 & 1.61 & 0.0053 & \multirow{3}{*}{$\begin{array}{l}\text { Chain A, Crystal Structure Of Human P32, A Doughnut-Shaped Acidic Mitochondrial } \\
\text { Matrix Protein }\end{array}$} \\
\hline & & dsYTX/MeOH & 0.0058 & 1.75 & 0.0053 & \\
\hline & & dsYTX/YTX & 0.39 & 1.09 & 0.0053 & \\
\hline \multirow{3}{*}{69} & \multirow{3}{*}{$4-7$} & $\mathrm{YTX} / \mathrm{MeOH}$ & 0.055 & -1.3 & 0.0064 & \multirow{3}{*}{$\begin{array}{l}\text { unnamed protein product \{match to Zn finger } 285 \text { A protein\} } \\
\text { (protein identification score was not significant) }\end{array}$} \\
\hline & & dsYTX/MeOH & 0.0059 & -1.52 & 0.0064 & \\
\hline & & dsYTX/YTX & 0.1 & -1.16 & 0.0064 & \\
\hline \multirow{3}{*}{70} & \multirow{3}{*}{$4-7$} & YTX/MeOH & 0.011 & -1.44 & 0.0016 & \multirow{3}{*}{$\begin{array}{l}\text { immunoglobulin heavy chain variable region } \\
\text { (protein identification score was not significant) }\end{array}$} \\
\hline & & dsYTX/MeOH & 0.0015 & -1.52 & 0.0016 & \\
\hline & & dsYTX/YTX & 0.52 & -1.06 & 0.0016 & \\
\hline \multirow{3}{*}{71} & \multirow{3}{*}{$4-7$} & YTX/MeOH & 0.00061 & 2.35 & 0.00013 & \multirow{3}{*}{$N / A$} \\
\hline & & dsYTX/MeOH & 0.0069 & 1.64 & 0.00013 & \\
\hline & & dsYTX/YTX & 0.0041 & -1.43 & 0.00013 & \\
\hline
\end{tabular}




\begin{tabular}{|c|c|c|c|c|c|c|}
\hline Spot \# & $\mathrm{pH}$ & Comparison & T-test & $\begin{array}{c}\text { Av. } \\
\text { Ratio }\end{array}$ & $\begin{array}{l}\text { 1-way } \\
\text { ANOVA }\end{array}$ & Name \\
\hline \multirow{3}{*}{72} & \multirow{3}{*}{$4-7$} & YTX/MeOH & 0.0016 & -2.26 & 0.00025 & \multirow{3}{*}{$\begin{array}{l}\text { similar to RIKEN CDNA } 1700016 G 05, \text { isoform CRA_c } \\
\text { (protein identification score was not significant) }\end{array}$} \\
\hline & & dsYTX/MeOH & 0.002 & -1.88 & 0.00025 & \\
\hline & & dsYTX/YTX & 0.082 & 1.2 & 0.00025 & \\
\hline \multirow{3}{*}{73} & \multirow{3}{*}{$4-7$} & YTX/MeOH & 0.019 & 1.32 & 0.0021 & \multirow{3}{*}{$N / A$} \\
\hline & & dsYTX/MeOH & 0.0035 & 1.57 & 0.0021 & \\
\hline & & dsYTX/YTX & 0.08 & 1.19 & 0.0021 & \\
\hline \multirow{3}{*}{74} & \multirow{3}{*}{$4-7$} & YTX/MeOH & 0.13 & -1.25 & 0.0081 & \multirow{3}{*}{$\begin{array}{c}\text { CALD1 protein } \\
\text { (protein identification score was not significant) }\end{array}$} \\
\hline & & dsYTX/MeOH & 0.0078 & -1.57 & 0.0081 & \\
\hline & & dsYTX/YTX & 0.027 & -1.26 & 0.0081 & \\
\hline \multirow{3}{*}{75} & \multirow{3}{*}{$4-7$} & $\mathrm{YTX} / \mathrm{MeOH}$ & 0.01 & 1.73 & 0.0027 & \multirow{3}{*}{$N / A$} \\
\hline & & dsYTX/MeOH & 0.0029 & 1.7 & 0.0027 & \\
\hline & & dsYTX/YTX & 0.97 & -1.02 & 0.0027 & \\
\hline \multirow{3}{*}{76} & \multirow{3}{*}{$4-7$} & YTX/MeOH & 0.018 & 1.51 & 0.009 & \multirow{3}{*}{$N / A$} \\
\hline & & dsYTX/MeOH & 0.037 & 1.42 & 0.009 & \\
\hline & & dsYTX/YTX & 0.24 & -1.06 & 0.009 & \\
\hline \multirow{3}{*}{77} & \multirow{3}{*}{$4-7$} & $\mathrm{YTX} / \mathrm{MeOH}$ & 0.0079 & -1.26 & $2.30 \mathrm{E}-05$ & \multirow{3}{*}{$\begin{array}{c}\text { STK35 protein } \\
\text { (protein identification score was not significant) }\end{array}$} \\
\hline & & dsYTX/MeOH & 0.00011 & -1.66 & $2.30 \mathrm{E}-05$ & \\
\hline & & dsYTX/YTX & 0.00093 & -1.32 & $2.30 \mathrm{E}-05$ & \\
\hline \multirow{3}{*}{78} & \multirow{3}{*}{$4-7$} & YTX/MeOH & 0.00044 & 2.91 & $5.50 \mathrm{E}-05$ & \multirow{3}{*}{$\begin{array}{c}\text { complement receptor } \\
\text { (protein identification score was not significant) }\end{array}$} \\
\hline & & dsYTX/MeOH & 0.012 & 1.63 & $5.50 \mathrm{E}-05$ & \\
\hline & & dsYTX/YTX & 0.00019 & -1.79 & $5.50 \mathrm{E}-05$ & \\
\hline \multirow{3}{*}{79} & \multirow{3}{*}{$4-7$} & YTX/MeOH & 0.0044 & 3.14 & 0.0021 & \multirow{3}{*}{$\begin{array}{l}\text { CDC28 protein kinase regulatory subunit } 1 B \\
\text { (protein identification score was not significant) }\end{array}$} \\
\hline & & dsYTX/MeOH & 0.037 & 1.91 & 0.0021 & \\
\hline & & dsYTX/YTX & 0.013 & -1.64 & 0.0021 & \\
\hline \multirow{3}{*}{80} & \multirow{3}{*}{$4-7$} & YTX/MeOH & 2.40E-05 & 2.12 & 3.90E-05 & \multirow{3}{*}{$\begin{array}{c}T \text { cell receptor } V \text { alpha } 9.1=\text { specific for mycobacterial heat shock protein 60-derived } \\
\text { peptide } P 1 \text { \{clone 2.4, complementarity-determining region 3\} [human, peripheral blood } \\
T \text { cells, Peptide Partial, } 29 \text { aa] (protein identification score was not significant) }\end{array}$} \\
\hline & & dsYTX/MeOH & 0.12 & 1.22 & 3.90E-05 & \\
\hline & & dsYTX/YTX & 0.00096 & -1.74 & $3.90 \mathrm{E}-05$ & \\
\hline \multirow{3}{*}{81} & \multirow{3}{*}{$4-7$} & YTX/MeOH & 0.012 & -1.73 & 0.006 & \multirow{3}{*}{$N / A$} \\
\hline & & dsYTX/MeOH & 0.026 & -1.53 & 0.006 & \\
\hline & & dsYTX/YTX & 0.19 & 1.13 & 0.006 & \\
\hline
\end{tabular}




\begin{tabular}{|c|c|c|c|c|c|c|}
\hline Spot \# & pH & Comparison & T-test & $\begin{array}{c}\text { Av. } \\
\text { Ratio }\end{array}$ & $\begin{array}{l}\text { 1-way } \\
\text { ANOVA }\end{array}$ & Name \\
\hline \multirow{3}{*}{82} & \multirow{3}{*}{$4-7$} & YTX/MeOH & 2.70E-06 & 3.26 & 2.60E-07 & \multirow{3}{*}{$\begin{array}{l}\text { signal recognition particle } 9 k D a \text {, isoform CRA_c } \\
\text { (protein identification score was not significant) }\end{array}$} \\
\hline & & dsYTX/MeOH & 0.00014 & 2.1 & 2.60E-07 & \\
\hline & & dsYTX/YTX & 0.0006 & -1.55 & $2.60 \mathrm{E}-07$ & \\
\hline \multirow{3}{*}{83} & \multirow{3}{*}{$4-7$} & $\mathrm{YTX} / \mathrm{MeOH}$ & 0.00019 & 1.98 & $3.90 \mathrm{E}-05$ & \multirow{3}{*}{$N / A$} \\
\hline & & dsYTX/MeOH & 0.0098 & 1.34 & $3.90 \mathrm{E}-05$ & \\
\hline & & dsYTX/YTX & 0.0015 & -1.47 & $3.90 \mathrm{E}-05$ & \\
\hline \multirow{3}{*}{84} & \multirow{3}{*}{$4-7$} & YTX/MeOH & 0.00073 & 2.17 & 0.00022 & \multirow{3}{*}{$\begin{array}{l}\text { unnamed protein product } \\
\text { (protein identification score was not significant) }\end{array}$} \\
\hline & & dsYTX/MeOH & 0.027 & 1.43 & 0.00022 & \\
\hline & & dsYTX/YTX & 0.0014 & -1.51 & 0.00022 & \\
\hline \multirow{3}{*}{85} & \multirow{3}{*}{$4-7$} & $\mathrm{YTX} / \mathrm{MeOH}$ & 0.00014 & 1.81 & $3.90 \mathrm{E}-05$ & \multirow{3}{*}{$N / A$} \\
\hline & & dsYTX/MeOH & 0.00073 & 1.52 & $3.90 \mathrm{E}-05$ & \\
\hline & & dsYTX/YTX & 0.057 & -1.19 & $3.90 \mathrm{E}-05$ & \\
\hline \multirow{3}{*}{86} & \multirow{3}{*}{$4-7$} & $\mathrm{YTX} / \mathrm{MeOH}$ & 0.0033 & 1.66 & 0.0021 & \multirow{3}{*}{$N / A$} \\
\hline & & dsYTX/MeOH & 0.0026 & 1.57 & 0.0021 & \\
\hline & & dsYTX/YTX & 0.68 & -1.06 & 0.0021 & \\
\hline \multirow{3}{*}{87} & \multirow{3}{*}{$4-7$} & YTX/MeOH & 0.11 & -1.28 & 0.0036 & \multirow{3}{*}{$N / A$} \\
\hline & & dsYTX/MeOH & 0.0032 & -1.72 & 0.0036 & \\
\hline & & dsYTX/YTX & 0.02 & -1.34 & 0.0036 & \\
\hline \multirow{3}{*}{88} & \multirow{3}{*}{$4-7$} & $\mathrm{YTX} / \mathrm{MeOH}$ & 0.0016 & 1.83 & 0.00035 & \multirow{3}{*}{$N / A$} \\
\hline & & dsYTX/MeOH & 0.0021 & 1.61 & 0.00035 & \\
\hline & & dsYTX/YTX & 0.19 & -1.14 & 0.00035 & \\
\hline \multirow{3}{*}{89} & \multirow{3}{*}{$4-7$} & YTX/MeOH & 0.13 & -1.21 & 0.011 & \multirow{3}{*}{$\begin{array}{c}\text { Unknown \{specific BLAST hit to } \alpha \text { crystalline domain found in small HSP } \alpha B \text { crystalline.\} } \\
\text { (protein identification score was not significant) }\end{array}$} \\
\hline & & dsYTX/MeOH & 0.012 & -1.53 & 0.011 & \\
\hline & & dsYTX/YTX & 0.05 & -1.26 & 0.011 & \\
\hline \multirow{3}{*}{90} & \multirow{3}{*}{$4-7$} & $\mathrm{YTX} / \mathrm{MeOH}$ & 0.24 & -1.26 & 0.02 & \multirow{3}{*}{$\begin{array}{l}\text { Full=MIF4G domain-containing protein; AltName: Full=SLBP-interacting protein 1; } \\
\text { Short=hSLIP1 (protein identification score was not significant) }\end{array}$} \\
\hline & & dsYTX/MeOH & 0.019 & -1.66 & 0.02 & \\
\hline & & dsYTX/YTX & 0.015 & -1.31 & 0.02 & \\
\hline \multirow{3}{*}{91} & \multirow{3}{*}{$4-7$} & YTX/MeOH & 0.0059 & -2.13 & 0.00055 & \multirow{3}{*}{$N / A$} \\
\hline & & dsYTX/MeOH & 0.0002 & -2.69 & 0.00055 & \\
\hline & & dsYTX/YTX & 0.31 & -1.26 & 0.00055 & \\
\hline
\end{tabular}




\begin{tabular}{|c|c|c|c|c|c|c|}
\hline Spot \# & pH & Comparison & T-test & $\begin{array}{c}\text { Av. } \\
\text { Ratio }\end{array}$ & $\begin{array}{l}\text { 1-way } \\
\text { ANOVA }\end{array}$ & Name \\
\hline \multirow{3}{*}{92} & \multirow{3}{*}{$4-7$} & YTX/MeOH & 0.0025 & 1.74 & $4.30 \mathrm{E}-05$ & \multirow{3}{*}{$\begin{array}{l}\text { immunoglobulin heavy chain variable region } \\
\text { (protein identification score was not significant) }\end{array}$} \\
\hline & & dsYTX/MeOH & 0.00012 & 2.17 & $4.30 \mathrm{E}-05$ & \\
\hline & & dsYTX/YTX & 0.022 & 1.24 & $4.30 \mathrm{E}-05$ & \\
\hline \multirow{3}{*}{93} & \multirow{3}{*}{$6-11$} & $\mathrm{YTX} / \mathrm{MeOH}$ & 0.031 & 1.65 & 0.024 & \multirow{3}{*}{$N / A$} \\
\hline & & dsYTX/MeOH & 0.086 & 1.32 & 0.024 & \\
\hline & & dsYTX/YTX & 0.088 & -1.26 & 0.024 & \\
\hline \multirow{3}{*}{94} & \multirow{3}{*}{$6-11$} & $\mathrm{YTX} / \mathrm{MeOH}$ & 0.012 & -1.57 & 0.014 & \multirow{3}{*}{$N / A$} \\
\hline & & $\mathrm{dsYTX/MeOH}$ & 0.066 & -1.34 & 0.014 & \\
\hline & & dsYTX/YTX & 0.18 & 1.17 & 0.014 & \\
\hline \multirow{3}{*}{95} & \multirow{3}{*}{$6-11$} & $\mathrm{YTX} / \mathrm{MeOH}$ & 0.0015 & -1.62 & 0.00046 & \multirow{3}{*}{$N / A$} \\
\hline & & $\mathrm{dsYTX/MeOH}$ & 0.018 & -1.33 & 0.00046 & \\
\hline & & dsYTX/YTX & 0.0048 & 1.22 & 0.00046 & \\
\hline \multirow{3}{*}{96} & \multirow{3}{*}{$6-11$} & $\mathrm{YTX} / \mathrm{MeOH}$ & 0.012 & -1.7 & 0.0076 & \multirow{3}{*}{$\begin{array}{l}\text { unnamed protein product }\{\text { specific BLAST hit K homology RNA-binding domain, type I. } \\
\qquad \mathrm{KH} \text { binds ss RNA/DNA }\end{array}$} \\
\hline & & dsYTX/MeOH & 0.071 & -1.39 & 0.0076 & \\
\hline & & dsYTX/YTX & 0.027 & 1.22 & 0.0076 & \\
\hline \multirow{3}{*}{97} & \multirow{3}{*}{$6-11$} & YTX/MeOH & 0.024 & 1.27 & 0.038 & \multirow{3}{*}{$N / A$} \\
\hline & & dsYTX/MeOH & 0.037 & 1.55 & 0.038 & \\
\hline & & dsYTX/YTX & 0.27 & 1.22 & 0.038 & \\
\hline \multirow{3}{*}{98} & \multirow{3}{*}{$6-11$} & $\mathrm{YTX} / \mathrm{MeOH}$ & 0.029 & 2.04 & 0.024 & \multirow{3}{*}{$N / A$} \\
\hline & & dsYTX/MeOH & 0.034 & 2.09 & 0.024 & \\
\hline & & dsYTX/YTX & 0.97 & 1.03 & 0.024 & \\
\hline \multirow{3}{*}{99} & \multirow{3}{*}{$6-11$} & YTX/MeOH & 0.0046 & 1.63 & 0.0018 & \multirow{3}{*}{$N / A$} \\
\hline & & dsYTX/MeOH & 0.0032 & 1.7 & 0.0018 & \\
\hline & & dsYTX/YTX & 0.75 & 1.04 & 0.0018 & \\
\hline \multirow{3}{*}{100} & \multirow{3}{*}{$6-11$} & $\mathrm{YTX} / \mathrm{MeOH}$ & 0.039 & 2.23 & 0.016 & \multirow{3}{*}{$\begin{array}{l}\text { hCG1647242 \{specific BLAST hit to Bel/Pao family of RNase HI in long-term repeat } \\
\text { retroelements\} (protein identification score was not significant) }\end{array}$} \\
\hline & & dsYTX/MeOH & 0.0071 & 3.06 & 0.016 & \\
\hline & & dsYTX/YTX & 0.29 & 1.37 & 0.016 & \\
\hline \multirow{3}{*}{101} & \multirow{3}{*}{$6-11$} & $\mathrm{YTX} / \mathrm{MeOH}$ & 0.014 & 1.92 & 0.0018 & \multirow{3}{*}{$\begin{array}{l}\text { hCG2042223 } \\
\text { (protein identification score was not significant) }\end{array}$} \\
\hline & & dsYTX/MeOH & 0.0012 & 2.47 & 0.0018 & \\
\hline & & dsYTX/YTX & 0.2 & 1.29 & 0.0018 & \\
\hline
\end{tabular}




\begin{tabular}{|c|c|c|c|c|c|c|}
\hline Spot \# & pH & Comparison & T-test & $\begin{array}{c}\text { Av. } \\
\text { Ratio }\end{array}$ & $\begin{array}{l}\text { 1-way } \\
\text { ANOVA }\end{array}$ & Name \\
\hline \multirow{3}{*}{102} & \multirow{3}{*}{$6-11$} & YTX/MeOH & 0.055 & 1.68 & 0.013 & \multirow{3}{*}{$\begin{array}{c}\text { tyrosine hydroxylase } \\
\text { (protein identification score was not significant) }\end{array}$} \\
\hline & & dsYTX/MeOH & 0.0028 & 2.13 & 0.013 & \\
\hline & & dsYTX/YTX & 0.28 & 1.27 & 0.013 & \\
\hline \multirow{3}{*}{103} & \multirow{3}{*}{$6-11$} & $\mathrm{YTX} / \mathrm{MeOH}$ & 0.28 & 1.19 & 0.047 & \multirow{3}{*}{$N / A$} \\
\hline & & dsYTX/MeOH & 0.027 & 1.5 & 0.047 & \\
\hline & & dsYTX/YTX & 0.12 & 1.26 & 0.047 & \\
\hline \multirow{3}{*}{104} & \multirow{3}{*}{$6-11$} & YTX/MeOH & 0.082 & -1.38 & 0.011 & \multirow{3}{*}{$N / A$} \\
\hline & & dsYTX/MeOH & 0.0027 & -1.89 & 0.011 & \\
\hline & & dsYTX/YTX & 0.16 & -1.36 & 0.011 & \\
\hline \multirow{3}{*}{105} & \multirow{3}{*}{$6-11$} & YTX/MeOH & 0.15 & -1.55 & 0.031 & \multirow{3}{*}{$N / A$} \\
\hline & & dsYTX/MeOH & 0.046 & -2.42 & 0.031 & \\
\hline & & dsYTX/YTX & 0.046 & -1.56 & 0.031 & \\
\hline \multirow{3}{*}{106} & \multirow{3}{*}{$6-11$} & YTX/MeOH & 0.052 & 1.63 & 0.025 & \multirow{3}{*}{ nucleolin, isoform CRA_c } \\
\hline & & dsYTX/MeOH & 0.02 & 1.72 & 0.025 & \\
\hline & & dsYTX/YTX & 0.69 & 1.05 & 0.025 & \\
\hline \multirow{3}{*}{107} & \multirow{3}{*}{$6-11$} & YTX/MeOH & 0.074 & 1.41 & 0.0075 & \multirow{3}{*}{ HNRPA1 protein } \\
\hline & & dsYTX/MeOH & 0.0011 & 1.7 & 0.0075 & \\
\hline & & dsYTX/YTX & 0.17 & 1.21 & 0.0075 & \\
\hline \multirow{3}{*}{108} & \multirow{3}{*}{$6-11$} & YTX/MeOH & 0.003 & 1.62 & 0.00034 & \multirow{3}{*}{$N / A$} \\
\hline & & $\mathrm{dsYTX} / \mathrm{MeOH}$ & 0.00025 & 1.77 & 0.00034 & \\
\hline & & dsYTX/YTX & 0.37 & 1.09 & 0.00034 & \\
\hline \multirow{3}{*}{109} & \multirow{3}{*}{$6-11$} & YTX/MeOH & 0.01 & 1.79 & 0.00052 & \multirow{3}{*}{$N / A$} \\
\hline & & dsYTX/MeOH & 0.0015 & 2.22 & 0.00052 & \\
\hline & & dsYTX/YTX & 0.035 & 1.24 & 0.00052 & \\
\hline \multirow{3}{*}{110} & \multirow{3}{*}{$6-11$} & YTX/MeOH & 0.02 & 2.32 & 0.024 & \multirow{3}{*}{$N / A$} \\
\hline & & dsYTX/MeOH & 0.072 & 1.84 & 0.024 & \\
\hline & & dsYTX/YTX & 0.23 & -1.26 & 0.024 & \\
\hline
\end{tabular}




\begin{tabular}{|c|c|c|c|c|c|c|}
\hline Spot \# & pH & Comparison & T-test & $\begin{array}{c}\text { Av. } \\
\text { Ratio }\end{array}$ & $\begin{array}{l}\text { 1-way } \\
\text { ANOVA }\end{array}$ & Name \\
\hline \multirow{3}{*}{111} & \multirow{3}{*}{ 6-11 } & YTX/MeOH & 0.38 & 1.11 & 0.01 & \multirow{3}{*}{$N / A$} \\
\hline & & dsYTX/MeOH & 0.013 & 1.57 & 0.01 & \\
\hline & & dsYTX/YTX & 0.017 & 1.41 & 0.01 & \\
\hline \multirow{3}{*}{112} & \multirow{3}{*}{$6-11$} & YTX/MeOH & 0.0007 & 1.85 & $9.50 \mathrm{E}-05$ & \multirow{3}{*}{$N / A$} \\
\hline & & dsYTX/MeOH & 0.00096 & 1.61 & $9.50 \mathrm{E}-05$ & \\
\hline & & dsYTX/YTX & 0.1 & -1.15 & $9.50 \mathrm{E}-05$ & \\
\hline \multirow{3}{*}{113} & \multirow{3}{*}{$6-11$} & YTX/MeOH & 0.1 & -1.21 & 0.00022 & \multirow{3}{*}{$N / A$} \\
\hline & & dsYTX/MeOH & 0.00013 & -1.76 & 0.00022 & \\
\hline & & dsYTX/YTX & 0.0031 & -1.46 & 0.00022 & \\
\hline \multirow{3}{*}{114} & \multirow{3}{*}{ 6-11 } & YTX/MeOH & 0.009 & -1.43 & 0.0024 & \multirow{3}{*}{$\begin{array}{c}\text { transgelin 2, isoform CRA_a } \\
\text { (protein identification score was not significant) }\end{array}$} \\
\hline & & dsYTX/MeOH & 0.0044 & -1.71 & 0.0024 & \\
\hline & & dsYTX/YTX & 0.14 & -1.19 & 0.0024 & \\
\hline \multirow{3}{*}{115} & \multirow{3}{*}{$6-11$} & YTX/MeOH & 0.074 & -1.38 & 0.047 & \multirow{3}{*}{$\begin{array}{c}\text { apolipoprotein } M, \text { isoform CRA_b } \\
\text { (protein identification score was not significant) }\end{array}$} \\
\hline & & dsYTX/MeOH & 0.031 & -1.54 & 0.047 & \\
\hline & & dsYTX/YTX & 0.5 & -1.11 & 0.047 & \\
\hline \multirow{3}{*}{116} & \multirow{3}{*}{$6-11$} & YTX/MeOH & 0.017 & -1.41 & 0.0022 & \multirow{3}{*}{$N / A$} \\
\hline & & dsYTX/MeOH & 0.0031 & -1.65 & 0.0022 & \\
\hline & & dsYTX/YTX & 0.13 & -1.17 & 0.0022 & \\
\hline \multirow{3}{*}{117} & \multirow{3}{*}{$6-11$} & $\mathrm{YTX} / \mathrm{MeOH}$ & 0.037 & -1.33 & 0.00075 & \multirow{3}{*}{$N / A$} \\
\hline & & dsYTX/MeOH & 0.0012 & -1.75 & 0.00075 & \\
\hline & & dsYTX/YTX & 0.012 & -1.32 & 0.00075 & \\
\hline \multirow{3}{*}{118} & \multirow{3}{*}{$6-11$} & YTX/MeOH & 0.27 & 1.26 & 0.0046 & \multirow{3}{*}{$\begin{array}{c}\text { unnamed protein product \{gene region Rossmann-fold NADP(+)-binding protein; highly } \\
\text { similar to pyruvate dehydrogenase regulatory subunit, } m R N A \text { \} (protein identification } \\
\text { score was not significant) }\end{array}$} \\
\hline & & dsYTX/MeOH & 0.0072 & 2.23 & 0.0046 & \\
\hline & & dsYTX/YTX & 0.0026 & 1.77 & 0.0046 & \\
\hline \multirow{3}{*}{119} & \multirow{3}{*}{$6-11$} & YTX/MeOH & 0.054 & 2.05 & 0.026 & \multirow{3}{*}{$N / A$} \\
\hline & & dsYTX/MeOH & 0.036 & 2.09 & 0.026 & \\
\hline & & dsYTX/YTX & 0.82 & 1.02 & 0.026 & \\
\hline
\end{tabular}


Table 8 HL60 protein abundance changes (Av. Ratio) and associated statistics acquired from DeCyder and protein identification for picked protein spots which did not show a change in abundance, as numbered in Fig. 14. Av. Ratio is the protein volume of the first condition compared to the second in the comparison. For example negative value when comparing dsYTX/untreated means that the protein has undergone a decrease in abundance in response to dsYTX respective to the untreated control.

* Indicates protein identification is not the top-ranked match.

\begin{tabular}{|c|c|c|c|c|c|c|}
\hline Spot \# & $\mathrm{pH}$ & Comparison & T-test & $\begin{array}{l}\text { Av. } \\
\text { Ratio }\end{array}$ & $\begin{array}{l}\text { 1-way } \\
\text { ANOVA }\end{array}$ & Name \\
\hline \multirow{6}{*}{01} & \multirow{6}{*}{$4-7$} & YTX/MeOH & 0.53 & 1.23 & 0.22 & \multirow{6}{*}{ MTHSP75* } \\
\hline & & dsYTX/MeOH & 0.0062 & 1.43 & 0.22 & \\
\hline & & dsYTX/YTX & 0.38 & 1.16 & 0.22 & \\
\hline & & YTX/MeOH & 0.93 & 1.06 & 0.61 & \\
\hline & & dsYTX/MeOH & 0.099 & 1.2 & 0.61 & \\
\hline & & dsYTX/YTX & 0.48 & 1.14 & 0.61 & \\
\hline \multirow{3}{*}{02} & \multirow{3}{*}{$4-7$} & YTX/MeOH & 0.27 & -1.24 & 0.38 & \multirow{3}{*}{ heat shock 70kDa protein 8 isoform 1 variant* } \\
\hline & & dsYTX/MeOH & 0.21 & -1.13 & 0.38 & \\
\hline & & dsYTX/YTX & 0.5 & 1.1 & 0.38 & \\
\hline \multirow{3}{*}{03} & \multirow{3}{*}{$4-7$} & $\mathrm{YTX} / \mathrm{MeOH}$ & 0.42 & -1.12 & 0.36 & \multirow{3}{*}{$\begin{array}{l}\text { unnamed protein product }\{\text { BLAST matches to protein disulfide isomerise (PDI) a, a', b, b' } \\
\text { families; ER\} }\end{array}$} \\
\hline & & dsYTX/MeOH & 0.49 & 1.09 & 0.36 & \\
\hline & & dsYTX/YTX & 0.22 & 1.22 & 0.36 & \\
\hline \multirow{3}{*}{04} & \multirow{3}{*}{$4-7$} & $\mathrm{YTX} / \mathrm{MeOH}$ & 0.85 & -1 & 0.18 & \multirow{3}{*}{ Chaperonin (HSP60) } \\
\hline & & dsYTX/MeOH & 0.022 & 1.26 & 0.18 & \\
\hline & & dsYTX/YTX & 0.16 & 1.26 & 0.18 & \\
\hline \multirow{3}{*}{05} & \multirow{3}{*}{$4-7$} & $\mathrm{YTX} / \mathrm{MeOH}$ & 0.67 & 1.05 & 0.2 & \multirow{3}{*}{ Chain A, TapasinERP57 HETERODIMER } \\
\hline & & dsYTX/MeOH & 0.087 & 1.2 & 0.2 & \\
\hline & & dsYTX/YTX & 0.17 & 1.14 & 0.2 & \\
\hline
\end{tabular}




\begin{tabular}{|c|c|c|c|c|c|c|}
\hline Spot \# & pH & Comparison & T-test & $\begin{array}{c}\text { Av. } \\
\text { Ratio }\end{array}$ & $\begin{array}{l}\text { 1-way } \\
\text { ANOVA }\end{array}$ & Name \\
\hline \multirow{3}{*}{06} & \multirow{3}{*}{$4-7$} & YTX/MeOH & 0.64 & -1.06 & 0.64 & \multirow{3}{*}{ unnamed protein product \{specific BLAST hit to $\beta$ tubulin\} } \\
\hline & & dsYTX/MeOH & 0.25 & -1.16 & 0.64 & \\
\hline & & dsYTX/YTX & 0.71 & -1.1 & 0.64 & \\
\hline \multirow{3}{*}{07} & \multirow{3}{*}{$4-7$} & YTX/MeOH & 0.38 & -1.14 & 0.48 & \multirow{3}{*}{ unnamed protein product \{specific BLAST hit to $\beta$ tubulin\} } \\
\hline & & $\mathrm{dsYTX} / \mathrm{MeOH}$ & 0.22 & -1.18 & 0.48 & \\
\hline & & dsYTX/YTX & 0.87 & -1.04 & 0.48 & \\
\hline \multirow{3}{*}{08} & \multirow{3}{*}{$4-7$} & YTX/MeOH & 0.49 & 1.23 & 0.45 & \multirow{3}{*}{ unnamed protein product \{specific BLAST hit to $\alpha$ tubulin\}* } \\
\hline & & $\mathrm{dsYTX/MeOH}$ & 0.13 & 1.35 & 0.45 & \\
\hline & & dsYTX/YTX & 0.64 & 1.1 & 0.45 & \\
\hline \multirow{3}{*}{09} & \multirow{3}{*}{$4-7$} & YTX/MeOH & 0.13 & -1.32 & 0.14 & \multirow{3}{*}{ unnamed protein product \{specific BLAST hit to $\alpha$ tubulin\} } \\
\hline & & dsYTX/MeOH & 0.041 & -1.38 & 0.14 & \\
\hline & & dsYTX/YTX & 0.89 & -1.05 & 0.14 & \\
\hline \multirow{3}{*}{010} & \multirow{3}{*}{$4-7$} & YTX/MeOH & 0.53 & -1.12 & 0.71 & \multirow{3}{*}{ unnamed protein product \{specific BLAST hit to actin\} } \\
\hline & & $\mathrm{dsYTX/MeOH}$ & 0.4 & -1.16 & 0.71 & \\
\hline & & dsYTX/YTX & 0.94 & -1.04 & 0.71 & \\
\hline \multirow{3}{*}{011} & \multirow{3}{*}{$4-7$} & YTX/MeOH & 0.28 & -1.25 & 0.42 & \multirow{3}{*}{ unnamed protein product \{specific BLAST hit to actin\} } \\
\hline & & $\mathrm{dsYTX} / \mathrm{MeOH}$ & 0.17 & -1.28 & 0.42 & \\
\hline & & $\mathrm{dsYTX/YTX}$ & 0.96 & -1.02 & 0.42 & \\
\hline \multirow{6}{*}{012} & \multirow{6}{*}{$6-11$} & YTX/MeOH & 0.16 & 1.32 & 0.13 & \multirow{6}{*}{$\begin{array}{l}\text { Chain A, Crystal Structure Of Human Phosphoglycerate Kinase Bound To D- } \\
\text { Adp/phosphoglycerate kinase 1, isoform CRA_b }\end{array}$} \\
\hline & & $\mathrm{dsYTX/MeOH}$ & 0.89 & -1.03 & 0.13 & \\
\hline & & dsYTX/YTX & 0.037 & -1.36 & 0.13 & \\
\hline & & $\mathrm{YTX} / \mathrm{MeOH}$ & 0.82 & -1.03 & 0.93 & \\
\hline & & dsYTX/MeOH & 0.71 & -1.06 & 0.93 & \\
\hline & & dsYTX/YTX & 0.92 & -1.03 & 0.93 & \\
\hline \multirow{3}{*}{013} & \multirow{3}{*}{$6-11$} & $\mathrm{YTX} / \mathrm{MeOH}$ & 0.23 & -1.09 & 0.16 & \multirow{3}{*}{17 kDa cyclophilin A (internal fragment) } \\
\hline & & $\mathrm{dsYTX} / \mathrm{MeOH}$ & 0.11 & -1.21 & 0.16 & \\
\hline & & dsYTX/YTX & 0.33 & -1.1 & 0.16 & \\
\hline
\end{tabular}




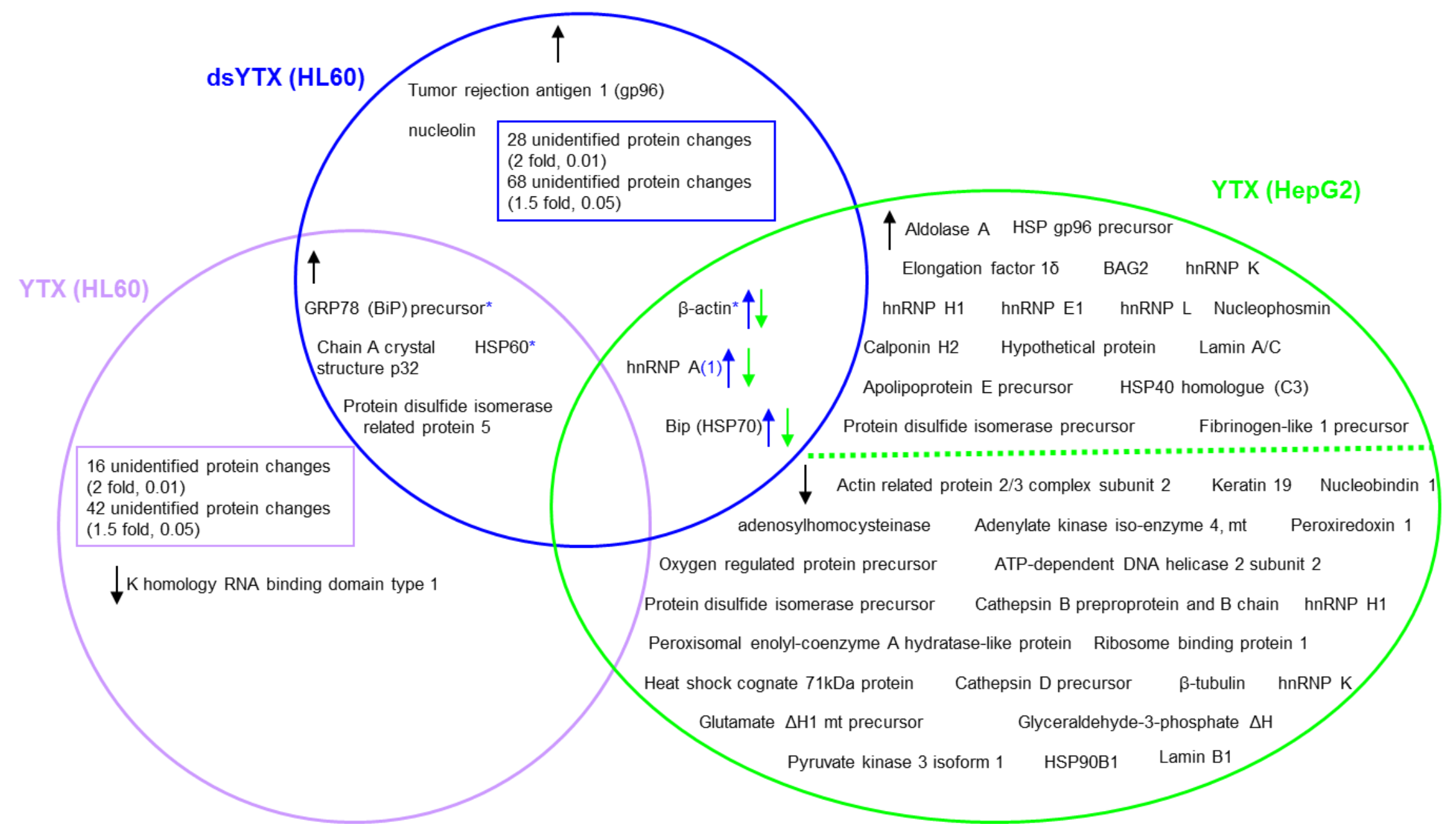

Figure 17 Proteins identified as changing in HL60 cells treated with YTX or dsYTX with MeOH as control, compared to changes found in HepG2 cells following $24 \mathrm{~h}$ incubation with YTX (Young et al., 2009). * denotes a 2 fold change, 0.01 (dsYTX or YTX only). Upwards pointing arrows indicate proteins which increased in abundance in response to treatment. Downwards pointing arrows indicate proteins which decreased in response to treatment. 


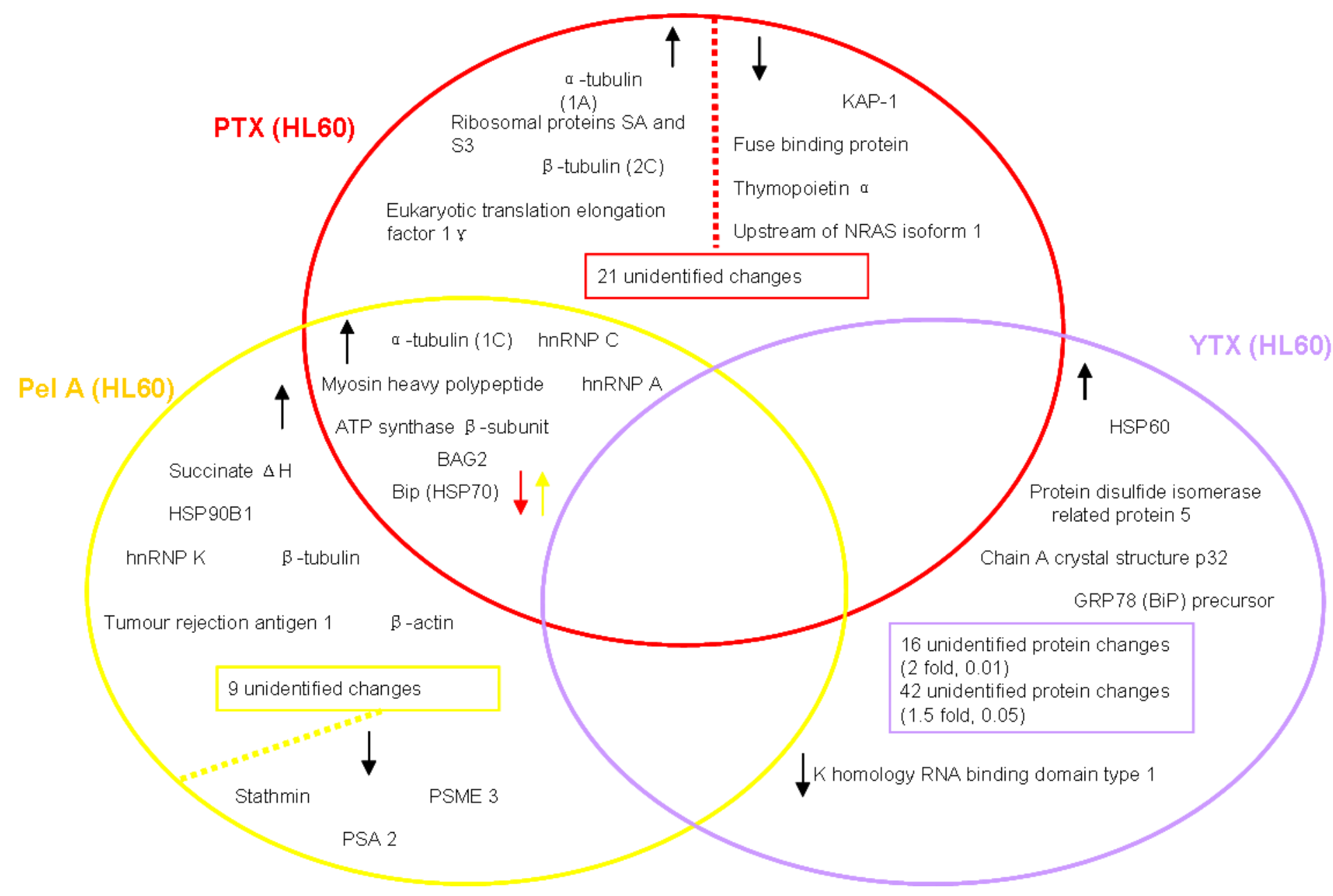

Figure 18 Proteins identified as changing in HL60 cells treated with either YTX with MeOH as control, or peloruside A (Pel A) or paclitaxel (PTX) (Wilmes et al., 2010 , 2011). * denotes a 2 fold change, 0.01 (dsYTX or YTX only). Upwards pointing arrows indicate proteins which increased in abundance in response to treatment. Downwards pointing arrows indicate proteins which decreased in response to treatment. 


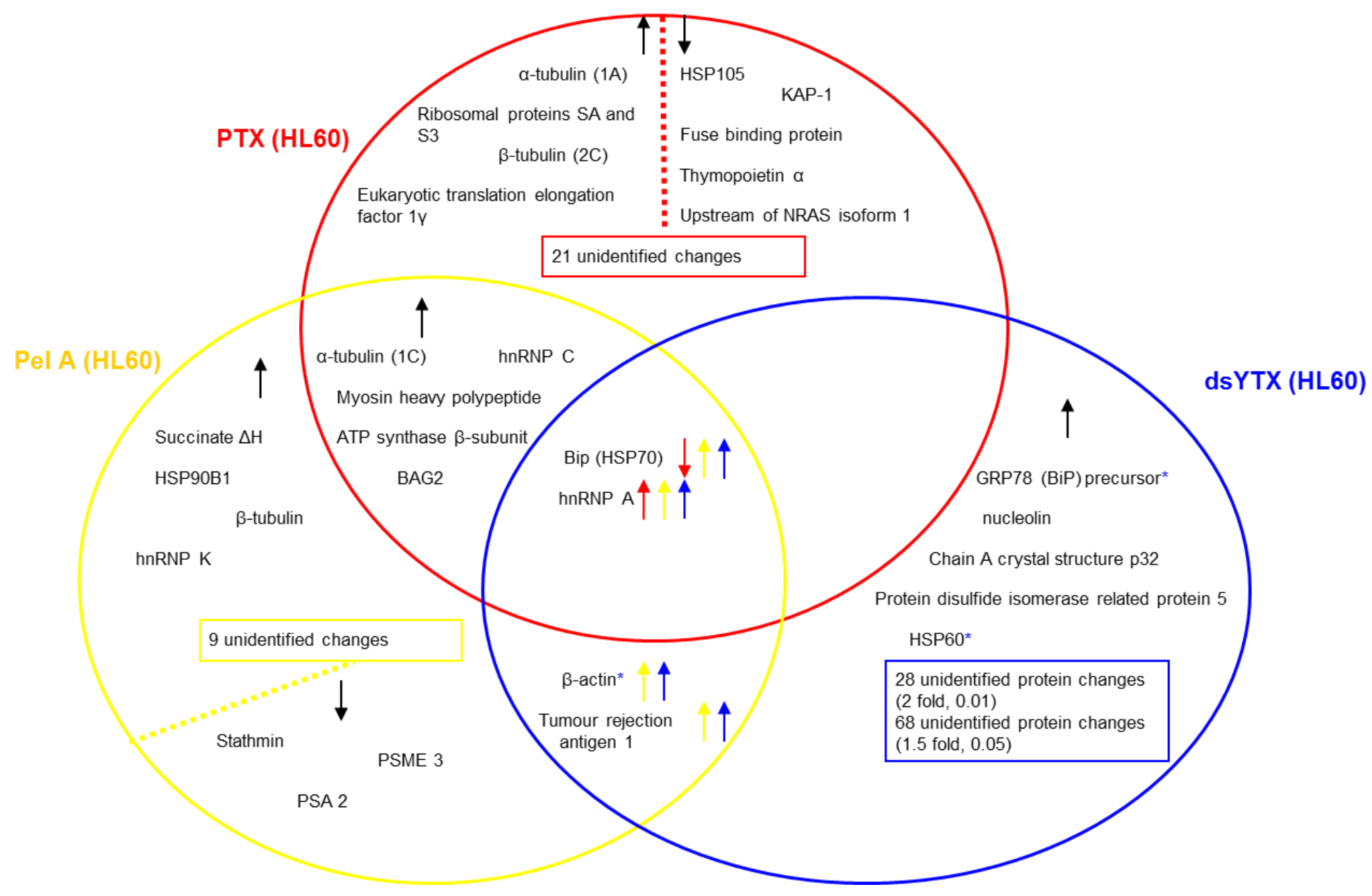

Figure 19 Proteins identified as changing in HL60 cells treated with dsYTX with MeOH as control, or peloruside A (Pel A) or paclitaxel (PTX) (Wilmes et al., 2011, 2012). * denotes a 2 fold change, 0.01 (dsYTX or YTX only). Upwards pointing arrows indicate proteins which increased in abundance in response to treatment. Downwards pointing arrows indicate proteins which decreased in response to treatment. 


\section{DISCUSSION}

\subsection{S. cerevisiae}

In initial experiments wild type $S$. cerevisiae cells were exposed to $1.2 \mu \mathrm{M}$ YTX. This concentration was selected to be comparable to the amount used by Young et al., in HepG2 cells.

The effects of YTX or dsYTX on yeast cell proteins were small and did not meet the criteria for significant change (Karp et al., 2007). These small changes were only observed when the FDR filter was not applied. The changes are reported, however, for comparison with effects seen in mammalian cells.

DIGE analysis showed no significant changes, using the $\geq 2$-fold, $p \leq 0.01$ criteria, in response to $1.2 \mu \mathrm{M}$ YTX. Of four protein spots showing a possible change $(\geq 1.5$ fold, $p$ $\leq 0.05)$ in abundance, two were identified with significant Mascot scores. Cytosolic aldehyde dehydrogenase showed a possible 1.51-fold decrease in abundance (spot 10) in YTX treated cells compared to untreated controls. S. cerevisiae phosphoglycerate mutase showed a possible 1.75-fold decrease in YTX treated cells when compared with untreated cells, but not methanol treated (spot 32). Spot 5 and Spot 17 also possibly decreased in abundance when treated with YTX compared with untreated or methanol treated controls respectively.

Yeast cells often require a higher toxin dose to have an effect than is seen with mammalian cells due to the presence of the yeast cell wall and a number of export pumps. Therefore in order to test if the small number of changes was due to the concentration of YTX used being too low, the effect of a 10-fold higher concentration on wild type stationary phase yeast cells was tested. This resulted in an increase in the number of changes detected when proteins from YTX treated cells were compared with those from methanol treated cells. These differences in abundance did not reach the criteria for significance and were not observed when toxin treated proteins were compared to those from untreated cells.

Log phase wild type cells were then exposed to YTX, as they can be more susceptible than stationary phase cells to the chemical effects. No significant changes in 
abundance were observed using the defined criteria. Seven of the 12 possible ( $\geq 1.5-$ fold, $p \leq 0.05)$ changes detected when YTX treated proteins were compared to untreated control samples also changed when the methanol treated and untreated controls were compared with each other. The fact that the changes were detected when controls were compared suggests that these differences in abundance were artefacts and not effects of the toxin.

The $A B C$ transporter pump knock-out mutant, $A D \Delta$, was used to examine whether the small number of changes observed was due to the toxin being removed from the cell before it had a chance to exert an effect. No changes were detected in stationary phase cells treated with 1.2 or $12 \mu \mathrm{M}$ YTX. Basic proteins from log phase cells treated with YTX also showed no differences from controls. While no significant protein changes were detected, three protein spots showed possible decreases in abundance (Spots 158, 160 and 163, Table 5) when compared with methanol treated or untreated controls. Three other protein spots showed apparent decreases in response to YTX when compared with methanol treated cells only. No changes were detected between the two control groups. Due to the small number of changes and the fact that the majority of the changing protein spots were low abundance, these protein spots were not excised from gels for identification.

YTX did not appear to have an effect on S. cerevisiae cells; however inhibition of yeast growth by YTX has been observed previously (Ogino et al., 1997). However in that study, YTX was applied at a much higher concentration $(50 \mu \mathrm{M})$, than was used in this project. It was also applied on a disk to Candida rugosa plate cultures, rather than administered in liquid cultures.

Significant changes in protein abundance were only detected in yeast cells treated with dsYTX. In wild type cells, GRE1 was identified as undergoing a 2.37-fold decrease in abundance in response to dsYTX compared with untreated controls. GRE1 is a hydrophillin induced in response to stress, and is regulated by the (HOG) MAPKpathway. Spot 156 showed a 2.13-fold decrease, but was too low in abundance to be extracted for MALDI TOF/TOF MSMS analysis. A possible, but not significant, change in abundance was also detected in mitochondrial aldehyde dehydrogenase. However 
Mascot scores for these identifications were below the significance threshold (score > $56, p \leq 0.05)$. These proteins were not identified as undergoing a change in abundance in HepG2 cells treated with YTX. The greater effect seen with dsYTX is consistent with dsYTX being a more potent inhibitor of yeast growth than YTX (Ogino et al., 1997).

DIGE analysis detected more changes in protein abundance in pump knock-out mutant cells exposed to dsYTX compared with wild type. Three protein spots showed significant changes in cells exposed to toxin. Spots 165 and 166 showed 2.5 and 2 -fold increases in response to dsYTX treatment respectively. Spot 200 showed an approximately 2.3-fold decrease when exposed to dsYTX. Unfortunately mass spectrometry analysis of these protein spots did not yield significant matches. The top-ranked match for each spot in order was YKR101Wp-like protein, Pau9 hypothetical protein product, and mitochondrial translational activator. Possible $(\geq$ 1.5-fold, $p \leq 0.05)$ increases in abundance were detected in protein spots identified as HSP90-Sba1 closed chaperone complex (chain A, spot 168, Table 5), YLL024Cp-like protein (spot 173), ATPase (involved in nuclear localisation signal directed nuclear transport), and translational elongation factor EF-1 $\alpha$ (spot 215). A possible decrease was detected in alcohol dehydrogenase isozyme I (spot 211). HSP90B1 and elongation factor $1 \delta$ were shown to decrease and increase respectively, in HepG2 cells exposed to YTX.

There did not seem to be any common pattern to the protein changes seen in $S$. cerevisiae. The exception was spots 38 and 159 (Figs. 7 and 10) which migrated to similar positions on their respective gels so may be the same protein. Both spots, in stationary wild type cells or log phase pump mutant cells respectively, showed a possible decrease when exposed to $12 \mu \mathrm{M}$ YTX. They are also possibly the same as spot 26 (Fig. 6), which was identified as triosephosphate isomerase, chain A. Spot 26 did not have a change in abundance in stationary wild type cells exposed to $1.2 \mu \mathrm{M}$ YTX.

Twenty-three proteins, which showed no change in protein abundance, were identified with significant Mascot scores (Appendix H). These included fructose-1,6aldolase, pyruvate kinase, actin, and SSE1 (ATPase component of the HSP9O co- 
chaperone complex) and the HSP90 co-chaperone protein. Changes in abundance were seen in proteins similar to these in HepG2 cells treated with YTX (Young et al., 2009). These were aldolase A, pyruvate kinase 3 (isoform 1), $\beta$-actin, and HSP90B1.

Possible reasons for the lack of a strong effect seen with YTX or dsYTX on S. cerevisiae cells include poor penetration of the toxins through the yeast cell wall, removal of the toxin by efflux pumps other than the $A B C$ transporters, or lack of proteins in $S$. cerevisiae structurally homologous to targets in mammalian cells. For example, although there are proteins functionally homologous to hnRNPs in yeast, they are not structurally identical to those in mammalian cells (Matunis et al., 1994, Denisenko et al., 2001, Jimeno et al., 2006).

\subsubsection{Summary}

Few changes were seen in S. cerevisiae cells treated with YTX. Significant changes in protein abundance were only observed in cells treated with dsYTX, with a possibly greater effect seen in the pump knock-out mutant strain. However, these changes were non-significant when the FDR filter was applied. A slight increase in the number of affected proteins was also seen in log phase cells from the mutant strain when treated with YTX. A significant decrease was seen in the abundance of GRE1 in YTX treated cells compared to untreated controls. Apparent increases were detected in the HSP90-Sba1 closed chaperone complex (chain A) and translational elongation factor EF-1 $\alpha$, when cells were exposed to dsYTX, compared to methanol treated controls. These proteins were also affected by YTX in HepG2 cells (Young et al., 2009).

No change in abundance was detected in fructose-1,6-aldolase, pyruvate kinase, actin, and SSE1 (ATPase component of the HSP9O co-chaperone complex) and the HSP9O cochaperone protein. However in HepG2 cells treated with YTX, changes in abundance were detected in protein similar to these. These were: aldolase A, pyruvate kinase 3 (isoform 1), $\beta$-actin, and HSP90B1 (Young et al., 2009).

The greater effect seen with dsYTX is consistent with previous research which showed dsYTX was a more potent inhibitor of yeast growth than YTX (Ogino et al., 1997). 
The slightly higher number of protein changes detected in the pump knock-out mutant implies that the $A B C$ transporters may be involved in export of the toxin.

As only a small number of changes in protein abundance were observed in $S$. cerevisiae cells exposed to YTXs, the planned chemical genetics experiments could not be carried out.

\subsection{HL60 cells}

\subsubsection{Morphological changes}

Following $24 \mathrm{~h}$ exposure to YTX, no differences in morphology were observed in HL60 cells compared to controls. However trypan blue staining showed a $12.7 \%$ decrease in the number of live cells. Exposure to dsYTX, caused cells to aggregate into clumps of various sizes. Trypan blue staining showed that the cells in these clumps were dead. A $24 \%$ decrease in the number of live cells was also seen.

\subsubsection{Protein changes}

\subsubsection{DeCyder Analysis}

A greater number of protein changes was observed in HL60 cells treated with YTX, than was seen in yeast. Sixteen protein spots were identified as undergoing a significant change in response to YTX. As was seen in yeast, dsYTX seemed to have a greater effect (Table 6, Figs. 15 and 16), with 32 proteins showing a significant change (Table 6). Of the 119 spots identified as changing, 33 showed a significant increase in abundance. Five showed a significant decrease in abundance.

When protein abundances from dsYTX treated cells were compared to those from YTX treated cells no significant differences were detected. DeCyder analysis showed that protein abundances seemed to be affected in a similar way by either toxin. Eight protein spots did, however, show a possible difference (between 1.5 and 2-fold 
change, $p \leq 0.05$ ) between the two toxins, but no identification was attained for these proteins.

\subsubsection{Protein identifications and comparison to HepG2, Pel A, and PTX}

\subsection{YTX vs. dsYTX in HL60 cells}

Four identified proteins changed in both YTX and dsYTX treated HL60 cells. Two of these were stress response proteins (HSP60 (chaperonin), GRP78 (BiP) precursor), one was a mitochondrial glycoprotein (chain A, p32/tat associated protein), the fourth was protein disulfide isomerase-related protein 5 . In HepG2 cells treated with YTX the protein disulfide isomerase precursor was found to be affected in HepG2 cells (Young et al., 2009). The two stress response proteins both showed a significant increase (approximately 2 and 2.5-fold for GRP78 precursor and HSP60, respectively, $p \leq 0.01$ ) in abundance in response to dsYTX. Apparent increases were also observed in response to YTX. Protein disulfide isomerase-related protein 5 and p32 (chain A) both showed possible increases of approximately 1.6 and 1.7-fold in response to YTX and dsYTX respectively. When the FDR filter was applied all four of these proteins no longer met the $p \leq 0.01$ cut-off but were significant at $p \leq 0.05$.

An unnamed protein, containing a $\mathrm{K}$ homology RNA binding, type 1 domain was identified as possibly decreasing (1.7-fold) in response to YTX. This domain is found in wide range of proteins, including proteins of the ribosome and transcription factors, including hnRNP $\mathrm{K}$, and is involved in binding single stranded RNA and DNA. A BLAST search of the top ranked protein identification suggests that it may be far upstream element-binding protein 1, which is involved in c-myc expression. Myc was identified as a hub protein in the IPA network analysis of proteins affected by Pel A (Wilmes et al., 2011).

Nucleolin and tumour rejection antigen 1 (gp96) showed increases in abundance, or 1.72 and 1.63 fold respectively, in HL60 cells treated with dsYTX compared to controls. The gp96 precursor underwent an increase in abundance in HepG2 cells following $24 \mathrm{~h}$ incubation with YTX (Young et al., 2009). When the FDR filter was applied the gp96 
precursor change still met the $\geq 1.5$-fold, $p \leq 0.05$ cut-off. Nucleolin did not meet this criteria.

\subsection{YTX and dsYTX in HL60 cells vs. HepG2 cells treated with YTX}

Identified proteins changing in HL60 cells when incubated with YTX or dsYTX for $24 \mathrm{~h}$ were compared with those previously found to be changing in HepG2 treated with YTX after $24 \mathrm{~h}$ of incubation (Fig. 17).

Actin ( $\beta$ ), hnRNP A, and BiP were found to be affected by dsYTX in HL60 cells and YTX in HepG2 cells. HnRNP A and BiP showed increases of 1.7 and 1.8-fold respectively. Actin ( $\beta$ ) showed a significant 2.27 fold increase. In HepG2 cells treated with YTX these proteins all decreased in abundance (Fig. 17, Young et al., 2009).

\subsection{Comparison of identified protein changes in HL6O cells}

No identified proteins were found to be changing in common between HL60 cells treated with PTX or Pel A and YTX. (Fig. 18)

BiP and hnRNP A were found to be changing in HL60 cells treated with PTX, Pel A or dsYTX. In almost all cases these proteins increased in abundance. The only exception was in PTX treated cells, where BiP underwent a decrease in abundance (Fig. 19).

Two identified proteins were affected by both Pel A and dsYTX. These were actin and tumour rejection antigen 1. Both proteins had an increase (actin: $\geq 2$-fold, 0.01 in dsYTX treated) in abundance compared to controls.

No identified proteins were found to be affected by both PTX and dsYTX, but not Pel A in HL60 cells.

\subsection{0ther proteins}

No changes in abundance were detected in response to either toxin for mitochondrial HSP75, HSP 70 kDa protein 8 isoform 1 variant, tapasin/ERP57 heterodimer (chain A), phosphoglycerate kinase (chain A), cylcophilin A (17 kDa fragment), or unnamed products with specific BLAST search hits to $\alpha$ - or $\beta$-tubulin. An unnamed protein product had a BLAST search match to protein disulfide isomerase $a, a^{\prime}, b$ and $b^{\prime}$ 
families. This contrasts to the results obtained for HL60 cells treated with PTX or Pel A (Wilmes et al., 2011, 2012) and HepG2 cells treated with YTX (Young et al., 2009). Tubulin decrease in abundance in HepG2 cells treated with YTX and increased in HL60 cells treated with Pel A. $\alpha$-tubulin abundance increased in HL60 cells when treated with PTX ( $\alpha$-tubulin $1 \mathrm{~A}$ ), or when treated with PTX or Pel A ( $\alpha$-tubulin $1 \mathrm{C}$ ).

\subsubsection{Summary}

YTX and dsYTX were more potent against mammalian HL60 cells than yeast. No change in morphology was observed in cells exposed to YTX for $24 \mathrm{~h}$, however trypan blue staining showed a $12.7 \%$ decrease in the number of live cells present. DsYTX may be affecting cell-cell adhesion in some way as when cells were exposed to it for $24 \mathrm{~h}$, they aggregated into clumps of dead cells. A $24 \%$ decrease in the number of live cells was also observed. It is not clear whether cell death occurred prior to or after cluster formation. Only a small number of the detected protein changes were able to be successfully identified. Of these hnRNP A and BiP (GRP78, HSP70) were identified as changing in response to treatment with dsYTX, Pel A or PTX in HL60 cells, and in response to YTX in HepG2 cells. Actin ( $\beta$ ) was affected by dsYTX and Pel A in HL60 cells, and YTX in HepG2 cells.

HSP60, GRP78 precursor, p32/tat associated protein, and protein disulfide isomeraserelated protein 5, underwent a change in abundance in response to YTX treatment and to dsYTX treatment. These proteins are mostly related to stress response.

Unexpectedly, none of the identified proteins which changed with response to YTX in HL60 cells were also changing in YTX treated HepG2 cells or in Pel A or PTX treated HL60 cells. However as the number of proteins identified was limited, this does not mean that there are no similar protein changes. This means that we were unable to distinguish toxin specific protein changes from those which are cell line specific. 


\subsection{Conclusions}

The small number of protein identifications limits the formation of a comprehensive conclusion. No significant changes in protein abundance or cell morphology were observed in S. cerevisiae cells treated with YTX. This suggests that YTX does not exert any significant effect on $S$. cerevisiae cells at the concentration used in either stationary or log phase. Significant changes in abundance were detected when stationary phase cells were exposed to dsYTX. This suggests that dsYTX is potentially more toxic to yeast than YTX. This disulfated compound may have greater penetration through the cell wall or a different mechanism of action or protein target than YTX which makes it more toxic to yeast.

A greater effect of both toxins was seen in mammalian cells compared with yeast. HL60 cells showed no morphological differences from controls when treated with YTX, however dsYTX treated cells aggregated into clumps of dead cells. Actin ( $\beta$ ), hnRNP A, and BiP were found to be affected by both YTX and dsYTX in HL6O cells. These proteins were also affected in YTX treated HepG2 cells (Young et al., 2009). These proteins increased in abundance in HL60 cells but were reported to decrease in HepG2 cells (Young et al., 2009). BiP and hnRNP A also showed an increase in HL60 cells treated with Pel A or PTX (Wilmes et al., 2011, 2012). This suggests that these proteins are a general response of HL60 cells to stress. No identified proteins were detected as changing in response to YTX in both HL60 and HepG2 cells. However, due to the small number of significant protein identifications it cannot be concluded that there were no similarities.

A greater number of changes in protein levels appeared to be produced by dsYTX compared with YTX in HL60 cells. However when the DIGE analyses of the two toxins were compared, there were few differences in abundance detected, even for protein spots which showed a change in abundance response to only one of the toxins. Proteins which underwent a change in abundance in response to treatment with either toxin were changed similarly. For example a protein spot which underwent an increase in abundance in response to YTX would also show an increase in response to dsYTX, although the fold-change in abundance could be different. 


\subsection{Future directions}

Further proteomic analysis of effects in HL60 cells could use either larger gels, which allow the application of greater protein loads than $7 \mathrm{~cm}$ gels, or gel-free shotgun proteomics methods. The advantage of the gel-based approach is that it allows the ready detection of protein isoforms formed from different post-translational modifications. Protein identifications should be validated by Western Blot analysis. Once a larger set of protein identifications is obtained IPA should then be used to identify the possible target pathways of YTX and dsYTX. These should then be compared to each other, and to those obtained by Young et al. (2009), in YTX treated HepG2 cells, and Wilmes et al. (2011) in HL60 cells treated with Pel A.

Observation of the cells over the course of exposure to the toxin could provide insight into how the toxic effects of each compound progresses. In particular it would be useful to learn more about the development of the cell aggregation seen with dsYTX treatment. Comparison of protein profiles from different time points would also be interesting to carry out, to observe any time dependent effects on protein expression. Annexin V/PI staining should also be carried out to determine if the cell death observed is apoptosis or necrosis.

If larger amounts of toxin are available, the effect of higher toxin concentrations on $S$. cerevisiae and $\mathrm{HL60}$ cells could be investigated. Determination of the $\mathrm{LC}_{50}$ and $\mathrm{IC}_{50}$ of YTX and dsYTX in these cell lines could help to determine the optimal concentration to use to observe toxin specific effects, with the least amount of general stress and cell death responses. 


\section{REFERENCES}

2-D Electrophoresis: Principles and Methods handbook, GE Healthcare

Aasen, J., Samdal, I.A., Miles, C.O., Dahl, E., Briggs, L.R., Aune, T. (2005) Yessotoxins in Norwegian blue mussels (Mytilus edulis): uptake from Protoceratium reticulatum, metabolism and depuration. Toxicon, 45, 265-272

Aasen, J.A.B., Espenes, A., Miles, C.O., Samdal, I.A., Hess, P., Aune, T. (2011) Combined oral toxicity of azaspiracid-1 and yessotoxin in female NMRI mice. Toxicon, 57, 909-917

Alfonso, A., de la Rosa, L., Vieytes, M.R., Yasumoto, T., Bontana, L.M. (2003) Yessotoxin, a novel phycotoxin, activates phosphodiesterase activity effect of yessotoxin on cAMP levels in human lymphocytes. Biochem. Pharm., 65, 193-208

Amzil, Z., Sibat, M., Royer, F., Savar, V. (2008) First report on azaspiracid and yessotoxin groups detection in French shellfish. Toxicon, 52, 39-48

Aune, T., Yasumoto, T., Engeland, E. (1991) Light and scanning electron microscopic studies on effects of marine algal toxins toward freshly prepared hepatocytes. $J$. Toxicol. Environ. Health, 34, 1-9

Aune, T., Sorby, R., Yasumoto, T., Ramstad, H., Landsverk, T. (2002) Comparison of oral and intraperitoneal toxicity of yessotoxin towards mice. Toxicon, 40, 77-82

Aune, T., Aasen, J.A.B., Miles, C.O., Larsen, S. (2008) Effect of mouse strain and gender on $\mathrm{LD}_{50}$ of yessotoxin. Toxicon, $52,535-540$

Bianchi, C., Fato, R., Angelin, A., Trombetti, F., Ventrella, Vittoria, Borgatti, A.R., Fattorusso, E., Ciminiello, P., Bernardi, P., Lenaz, G., Castelli, G.P. (2004) Yessotoxin, a shellfish biotoxin, is a potent inducer of the permeability transition in isolated mitochondria and intact cells. Biochimica et Biophysica Acta, 1656, 139-147

Callegari, F., Sosa, S ., Ferrari, S., Soranzo, M.R., Pierotti, S., Yasumoto, T., Tubaro, A., Rossini, G.P. (2006) Oral administration of yessotoxin stabilizes E-cadherin in mouse colon. Toxicology, 227, 145-153

Ciminiello, P., Dell'Aversano, C., Fattorusso, E., Forino, M., Grauso, L., Magno, S.G., Poletti, R., Tartaglione, L. (2007) Desulfoyessotoxins from Adriatic mussels: A new problem for seafood safety control. Chem. Res. Toxicol., 20, 95-98

de la Rosa, L.A., Alfonso, A., Vilariño, N., Vieytes, M.R., Botana, L.M. (2001) Modulation of cytosolic calcium levels of human lymphocytes by yessotoxin, a novel marine phycotoxin. Biochem. Pharm., 61, 827-833 
Dell'Ovo, V., Bandi, E., Coslovich, T., Florio, C., Sciancalepore, M., Decorti, G., Sosa, S., Lorenzo, P., Yasumoto, T., Tubaro, A. (2008) In vitro effects of yessotoxin on a primary culture of rat cardiomyocytes. Toxicol. Sci., 106, 392-399

Denisenko, O., Bomsztyk, K. (2002) Yeast hnRNP-like genes are involved in regulation of the telomeric position effect and telomere length. Mol. Cell Biol., 22, 286-297

Dominguez, H.J., Paz, B., Daranas, A.H., Norte, M., Franco, J.M., Fernández, J.J. (2010) Dinoflagellate polyether within the yessotoxin, pectenotoxin and okadaic acid toxin groups: Characterization, analysis and human health implications. Toxicon, 56, 191217

EC Commission Decision 2002/225/EC of 15 March 2002. Laying down detailed rules for the implementation of Council Directive 91/492/EEC as regards the maximum levels and the methods of analysis of certain marine biotoxins in bivalve molluscs, echinoderms, tunicates and marine gastropods. Official Journal of the European Communities, L75 of 15 March 2002, 62-64

EC Regulation No 853/2004 of the European Parliament and of the Council of 29 April 2004 laying down specific hygiene rules for food of animal origin. Official Journal of the European Union, L139 of 30 April 2004, 22-82

Evans, D.A., Kvœrnø, L., Mulder, J.A., Raymer, B., Dunn, T.B., Beauchemin, A., Olhava, E.J., Juhl, M., Kagechika, K. (2007) Total synthesis of (+)-Azaspiracid-1. Part I: Synthesis of the fully elaborated ABCD aldehyde. Angew. Chem. Int. Ed., 46, 4693-4697

Franchini, A., Marchesini, E., Poletti, R., Ottaviani, E. (2004a) Acute toxic effect of the algal yessotoxin on Purkinje cells from the cerebellum of Swiss CD1 mice. Toxicon, 43, 347-352

Franchini, A., Marchesini, E., Poletti, R., Ottaviani, E. (2004b) Lethal and sub-lethal yessotoxin dose-induced morpho-functional alterations in intraperitoneal injected Swiss CD1 mice. Toxicon, 44, 83-90

García, C., Truan, D., Lagos, M., Santelices, J.P., Díaz, J.C., Lagos, N. (2005) Metabolic transformation of dinophysistoxin-3 into dinophysistoxin-1 causes human intoxication by consumption of $\mathrm{O}$-acyl-derivatives dinophysistoxins contaminated shellfish. $J$. Toxicol. Sci., 30, 287-296

Howard, M.D.A., Smith, G.J., Kudela, R.M. (2009) Phylogenetic relationships of yessotoxin-producing dinoflagellates based on the large subunit and internal transcribed spacer ribosomal DNA domains. Appl. Environ. Microb., 75, 54-63 
Inoue, M., Hirama, M., Satake, M., Sugiyama, K., Yasumoto, T. (2003) Inhibition of brevetoxin binding to the voltage-gated sodium channel by gambierol and gambieric acid-A. Toxicon, 41, 469-474

Jimeno, S., Luna, R., García-Rubio, M., Aguilera, A. (2006) Tho1, a novel hnRNP, and Sub2 provide alternative pathways for mRNP biogenesis in yeast THO mutants. Mol. Cell Biol., 26, 4387-4398

Karp, N.A., Lilley, K.S. (2007) Design and analysis issues in quantitative proteomics studies. Proteomics, 7 (Suppl 1), 42-50

Keller, B.O., Sui, J., Young, A.B., Whittal, R.M. (2008) Interferences and contaminants encountered in modern mass spectrometry. Analytica Chimica Acta, 627, 71-81

Kolkman, A., Slijper, M., Heck, A.J.R. (2005) Development and application of proteomics technologies in Saccharomyces cerevisiae. Trends in Biotechnology, 23, 598-604

Korsnes, M.S., Hetland, D.L., Espenes, A., Tranulis, M.A., Aune, T. (2006) Apoptotic events induced by yessotoxin in myoblast cell lines from rat and mouse. Toxicol. in Vitro, 20, 1077-1087

Korsnes, M.S., Hetland, D.L., Espenes, A., Aune, T. (2007) Cleavage of tensin during cytoskeleton disruption in YTX-induced apoptosis. Toxicol. in Vitro, 21, 9-15

Korsnes, M.S., Espenes, A., Heltand, D.L., Hermansen, L.C. (2011) Paraptosis-like cell death induced by yessotoxin. Toxicol. in Vitro, 25, 1764-1777

Lamping, E., Monk, B.C., Niimi, K., Holmes, A.R., Tsao, S., Tanabe, K., Niimi, M., Uehara, Y., Cannon, R.D. (2007) Characterization of three classes of membrane proteins involved in fungal azole resistance by functional hyperexpression in Saccharomyces cerevisiae. Eukaryotic Cell, 6, 1150-1165

Leira, F., Alvarez, C., Vieites, J.M., Vieytes, M.R., Botana, L.M. (2002) Characterization of distinct apoptotic changes induced by okadaic acid and yessotoxin in the BE(2)-M17 neuroblastoma cell line. Toxicol. in Vitro, 16, 23-31

Lin, Y.Y., Risk, M., Ray, S.M., Engen, D.V., Clardy, J., Golik, J., James, J.C., Nakanishi, K. (1981) Isolation and structure of brevetoxin B from the "Red Tide" dinoflagellate Ptychodiscus brevis (Gymnodinium breve). J. Am. Chem. Soc., 103, 6773-6778

López, A.M., Rodríguez, J.J.G, Mirón, A.S., Camacho, F.G., Grima, E.M. (2011) Immunoregulatory potential of marine algal toxins yessotoxin and okadaic acid in mouse T lymphocyte cell line EL-4. Toxicol. Letters, 207, 167-172 
MacKenzie, L., Holland, P., McNabb, P., Beuzenberg, V., Selwood, A., Suzuki, T. (2002) Complex toxin profiles in phytoplankton and Greenshell mussels (Perna canaliculus), revealed by LC-MS/MS analysis. Toxicon, 40, 1321-1330

Malagoli, D., Marchesini, E., Ottaviani, E. (2006a) Lysosomes as the target of yessotoxin in invertebrate and vertebrate cell lines. Toxicology Letters, 167, 75-83

Malagoli, D., Casarini, L., Ottaviani, E. (2006b) Algal toxin yessotoxin signalling pathways involve immunocyte mussel calcium channels. Cell Biol. Int., 30, 721-726

Malaguti, C., Ciminiello, P., Fattorusso, E., Rossini, G.P. (2002) Caspase activation and death induced by yessotoxin in HeLa cells. Toxicol. in Vitro, 16, 357-363

Matunis, M.J., Xing, J., Dreyfuss, G. (1994) The hnRNP F protein: unique primary structure, nucleic acid-binding properties, and subcellular localization. Nucleic Acids Res., 22, 1059-1067

Miles, C.O., Samdal, I.A., Aasen, J.A.G., Jensen, D.J., Quilliam, M.A., Petersen, D., Briggs, L.M., Wilkins, A.L., Rise, F., Cooney, J.M., MacKenzie, A.L. (2005) Evidence for numerous analogs of yessotoxin in Protoceratium reticulatum. Harmful Algae, 4, 10751091

Mori, M., Oishi, T., Matsuoka, S., Ujihara, S., Matsumori, N., Murata, M., Satake, M., Oshima, Y., Matsushita, N., Aimoto, S. (2005) Ladder-shaped polyether compound, desulfated yessotoxin, interacts with membrane-integral $\alpha$-helix peptides. Bioorg. Med. Chem, 13, 5099-5103

Murata, M., Kumagai, M., Lee, J.S., Yasumoto, T. (1987) Isolation and structure of yessotoxin, a novel polyether compound implicated in diarrhetic shellfish poisoning. Tetrahedron Letters, 28, 5869-5872

Nicolaou, K.C., Baker, T.M., Nakamura, T. (2011) Synthesis of the WXYZA' Domain of Maitotoxin. J. Am. Chem. Soc., 133, 220-226

Ogino, H., Kumagi, M., Yasumoto, T. (1997) Toxicological evaluation of yessotoxin. Nat. Toxins, 5, 255-259

Orsi, C.F., Colombari, B., Callegari, F., Todaro, A.M., Ardizzoni, A., Rossini, G.P., Blasi, E., Peppoloni, S. (2010) Yessotoxin inhibits phagocytic activity of macrophages. Toxicon, $55,265-273$

Pang, M, Wang, Z.L., Gao, C.L., Qu, P., Li, H.D. (2011) Characterization of apoptotic changes induced by yessotoxin in the Bel7402 human hepatoma cell line. Mol. Med. Reports, 4, 547-552 
Pérez-Gómez, A., Ferrero-Gutierrez, A., Novelli, A., Franco, J.M., Paz, B., FernándezSánchez, M.T. (2006) Potent neurotoxic action of the shellfish biotoxin yessotoxin on cultured cerebellar neuron. Toxicol. Sciences, 90, 168-177

Röder, K., Fritz, N., Gerdts, G., Luckas, B. (2011) Accumulation and depuration of yessotoxin in two bivalves. J. Shellfish Res., 30, 167-175

Ronzitti, G., Callegari, F., Malaguti, C., Rossini, G.P. (2004) Selective disruption of Ecadherin-catenin system by an algal toxin. Brit. J. Cancer, 90, 1100-1107

Satake, M., MacKenzie, L., Yasumoto, T. (1997) Identification of Protoceratium reticulatum as the biogenetic origin of yessotoxin. Nat. Toxins, 5, 164-167

Sperandio, S., de Belle, I., Bredesen, D.E. (2000) An alternative, non-apoptotic form of programmed cell death. PNAS, 97, 14376-14381

Terao, K., Ito, E., Oarada, M., Murata, M., Yasumoto, T. (1990) Histopathological studies on experimental marine toxin poisoning -5 . The effects in mice of yessotoxin isolated from Patinopecten yessoensis and of a desulfated derivative. Toxicon, 28, 1095-1104

Tubaro, A., Sosa, S., Carbonatto, M., Altinier, G., Vita, F., Melato, M., Satake, M., Yasumoto, T. (2003) Oral and intraperitoneal acute toxicity studies of yessotoxin and homoyessotoxins in mice. Toxicon, 41, 783-792

Tubaro, A., Giangaspero, A., Ardizzone, M., Soranzo, M.R., Vita, F., Yasumoto, T., Maucher, J.M., Ramsdell, J.S., Sosa, S. (2008) Utrastructural damage to heart tissue from repeated oral exposure to yessotoxin resolves in 3 months. Toxicon, 51, 12251235

Vermes, I., Haanen, C., Steffens-Nakken, H., Reutelingsperger, C. (1995) A novel assay for apoptosis: Flow cytometric detection of phosphatidylserine expression on early apoptotic cells using fluorescein labelled Annexin V. J. Immunol. Methods, 184, 39-51

Wilmes, A., Chan, A., Rawson, P., Jordan, T.W., Miller, J.H. (2012) Paclitaxel effects on the proteome of HL-60 promyelocytic leukemic cells: comparison to peloruside $A$. Invest. New Drugs, 30, 121-129

Wilmes, A., Rawson, P., Peng, L., McLauchlan, D., Northcote, P.T., Jordan, T.W., Miller, J.H. (2011) Effects of the microtubule stabilizing agent peloruside $A$ on the proteome of HL-60 cells. Invest. New Drugs, 29, 544-553

Young, C., Truman, P., Boucher, M., Keyzers, R.A., Northcote, P., Jordan, T.W. (2009) The algal metabolite yessotoxin affects heterogeneous nuclear ribonucleoproteins in HepG2 cells. Proteomics, 9, 2529-2542 
APPENDICES 


\section{Appendix A}

\section{Symbol key for IPA networks}

\section{Function}

Circle

Circle (double)

Diamond

Hexagon

Oval

Rectangle (dotted)

Rectangle (solid)

Square

Trapezium

Triangle (downward pointing)

Triangle (upward pointing)

Interaction

Arrow, solid line

Arrow, dotted line

Dotted line

Solid line
Other

Group/complex

Enzyme

Translation regulator

Transcription regulator

Ion channel

G-protein nuclear receptor

Cytokine

Transporter

Kinase

Phosphatase

Direct action (protein acts on another to influence expression)

Indirect association

Indirect action

Binding 


\section{Gene abbreviations}

HepG2 cells and YTX

ACTB

$\beta$-actin

AHCY

S-adenosylhomocysteine hydrolase

ALDOA

aldolase $\mathrm{A}$

BAG2

BCL2-associated anthanogene 2

CCN2

calponin 2

DNAJC3

DNA J (Hsp40) homologue, subfamily C, member 3

HNRNPA2B1

hnRNP A2/B1

HNRNPL

hnRNP L

HNRNPK

hnRNP K

HSP90B1

heat shock protein $90 \mathrm{kDa} \beta$ (Grp94), member 1

HSPA8

heat shock $70 \mathrm{kDa}$ protein 8

HSPA9

heat shock $70 \mathrm{kDa}$ protein 9 (mortalin)

PCBP1

hnRNP E1

PKM2

pyruvate kinase, muscle

XRCC5

X-ray repair complementing defective repair in Chinese hamster cells 5 


\section{HL60 cells and Pel A}

ACAT2

BIK

CAPZB

CLIC4

COTL1

DSTN

EEF1D

EIF3D

EIF3F

EIF4E

ERN1

GARS

HNRNPC

HSP90AA2

HSPA1B

IFI6

IGK@

IKBKE

Immunoproteasome Pa28/20s

KHSRP

LMNB2

MSR1

MYC acetyl-coenzyme A acetyltransferase 2

BCL2-interacting killer

F-actin-capping subunit $\beta$

chloride intracellular channel 4

coactosin-like 1

destrin

eukaryotic translation elongation factor $1 \delta$

eukaryotic translation initiation factor 3 , subunit D

eukaryotic translation initiation factor 3 , subunit $F$

eukaryotic translation initiation factor 4E

ER to nucleus signalling 1 protein

glycyl-tRNA synthetase

heterogeneous nuclear ribonucleoprotein C

heat shock protein $90 \mathrm{kDa} \alpha$, class A member 2

heat shock protein 1B

interferon, alpha-inducible protein 6

immunoglobulin kappa locus

inhibitor of kappa light polypeptide gene

enhancer in B cells, kinase epsilon

proteasome activator subunit 1 (PA28 alpha)

$\mathrm{KH}$-type splicing regulatory protein

lamin B2

macrophage scavenger receptor 1

v-myc myelocytomatosis viral oncogene homolog (avian) 
MYH9

PDGFB

PRDX3

Proteasome PA700/20s

PSMA1

PSMB4

PSMC4

SDHA

SRXN1

STMN1

TNF myosin

platelet derived growth factor, B polypeptide

peroxiredoxin 3

proteasome activator subunit 1 (PA28 alpha)

proteasome subunit, alpha type 1

proteasome subunit, beta type, 4

proteasome 26 s subunit

succinate dehydrogenase complex, subunit $A$, flavoprotein

sulfiredoxin 1 homolog (S. cerevisiae)

stathmin 1/oncoprotein 18

tumour necrosis factor (TNF superfamily, member 2) 


\section{Appendix B}

LC-MS analysis of the compounds was carried out by Andy Selwood of the Cawthron Institute, Nelson, New Zealand. The analysis determined that the stock solutions of each compound were pure. The YTX stock contained no detectable traces of other YTX analogues. The dsYTX stock contained only trace (ca 1\%) amounts of YTX.

The YTX and dsYTX samples sent for analysis were supposed to contain $100 \mu \mathrm{g}$ and 25 $\mu \mathrm{g}$ of toxin respectively. LC-MS-MS analysis determined the amount of YTX to be 50 $\mu \mathrm{g}$. UV comparison of the dsYTX sample to the Cawthron Institute's dsYTX standard determined the quantity of toxin present to be $19 \mu \mathrm{g}$. This means there is potentially some difference between the intended concentration of toxin used to treat samples, and the actual. However since only small samples $(10 \mu \mathrm{L}$ and $5 \mu \mathrm{L}$ for YTX and dsYTX respectively), it is also possible that some may have evaporated in transit between Wellington and Nelson.

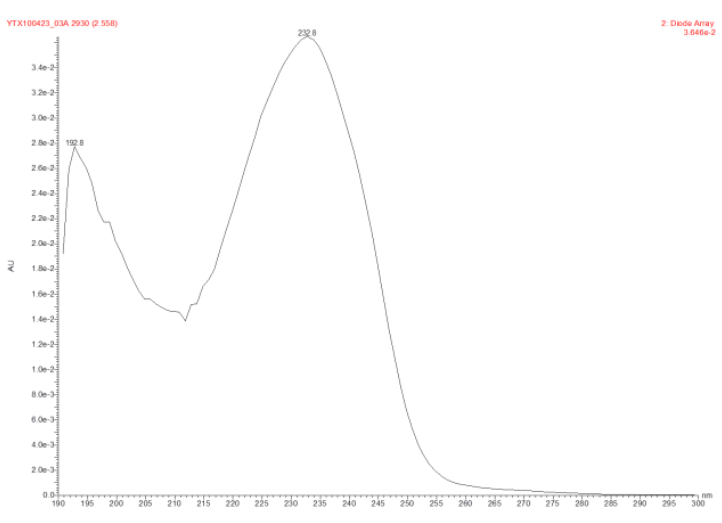

UV spectrum of YTX

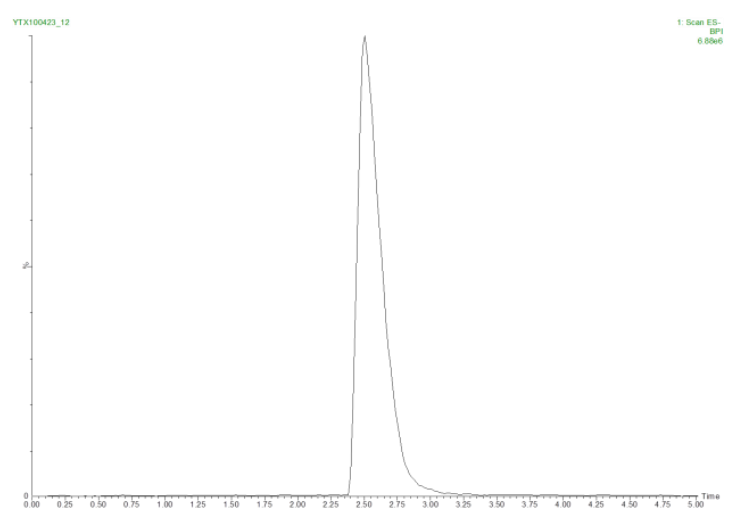

LC-MS negative ion of YTX

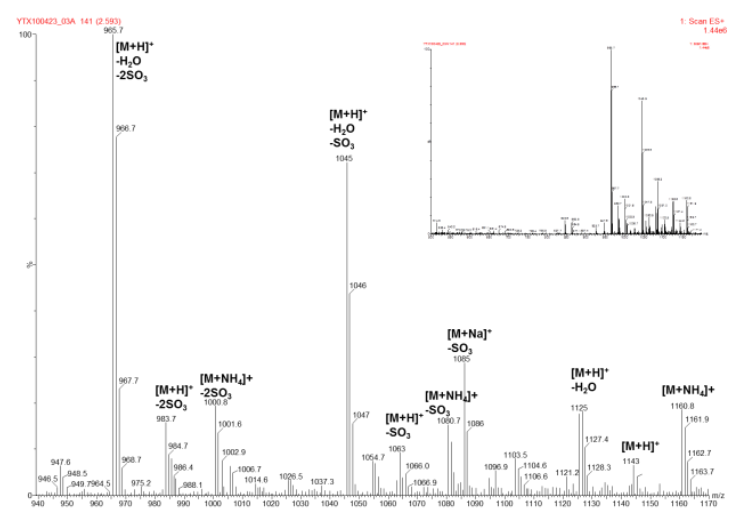

Positive ion MS spectrum of YTX

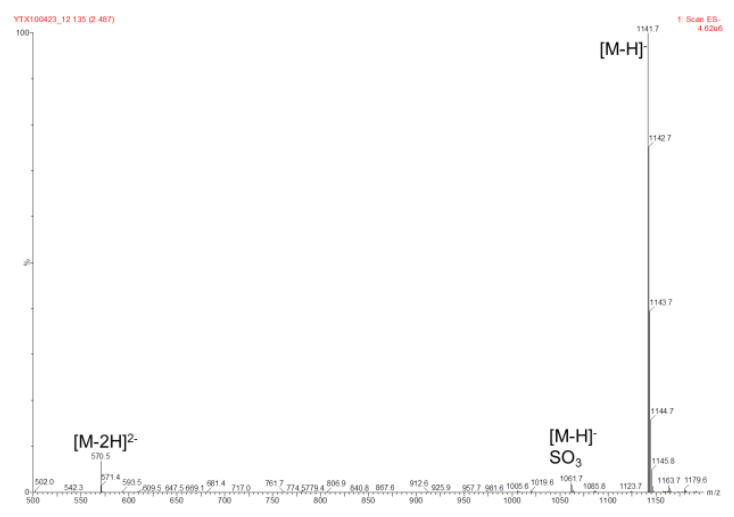

LC-MS negative ions MS spectrum of YTX 


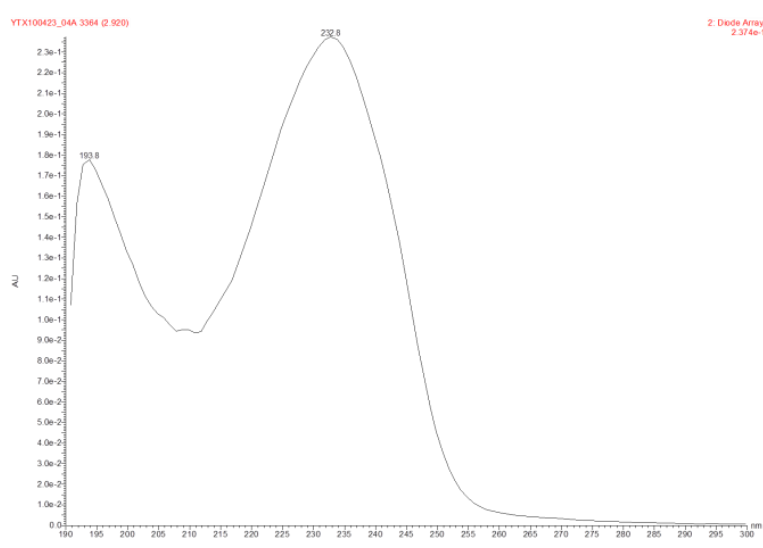

UV spectrum of dsYTX

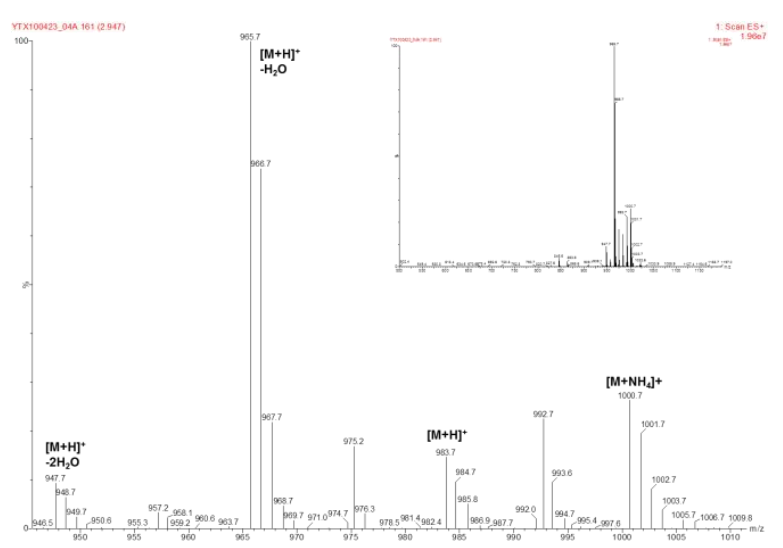

Positive ion MS spectrum of dsYTX

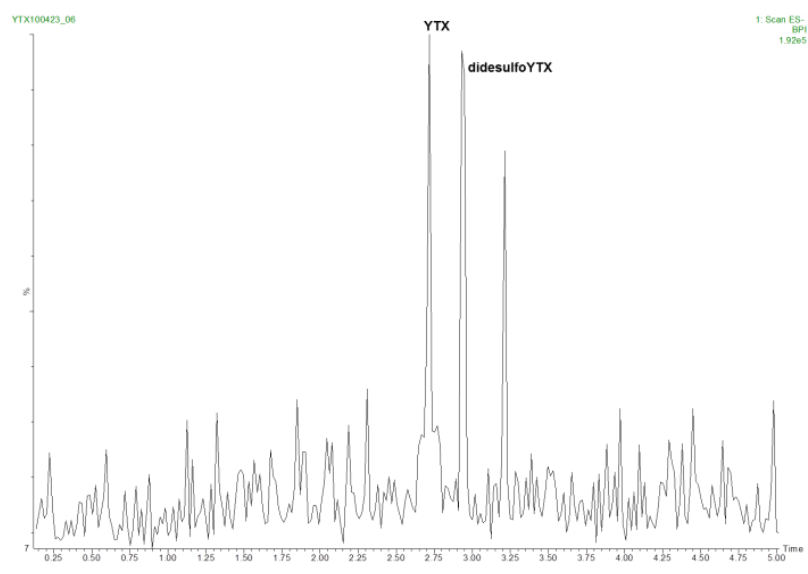

LC-MS negative ions MS spectrum of dsYTX 


\section{Appendix C}

Example template for a DIGE experiment ( $n=4,3$ treatment conditions)

PROTEIN LOAD: $20 \mu \mathrm{g} /$ dye/strip

DYE/PROTEIN: 80 pmols $/ 20 \mu \mathrm{g}$

WORKING DYE SOL'N.: $1.2 \mu \mathrm{L}$ dye $+4.8(5) \mu \mathrm{L}$ DMF (1 pH range)

$2.4 \mu \mathrm{L}$ dye $+9,6(10) \mu \mathrm{L}$ DMF (2 pH ranges)

STRIPS: $7 \mathrm{~cm} ; 4-7 / 6-11$

CHECK pH SAMPLES (>8)

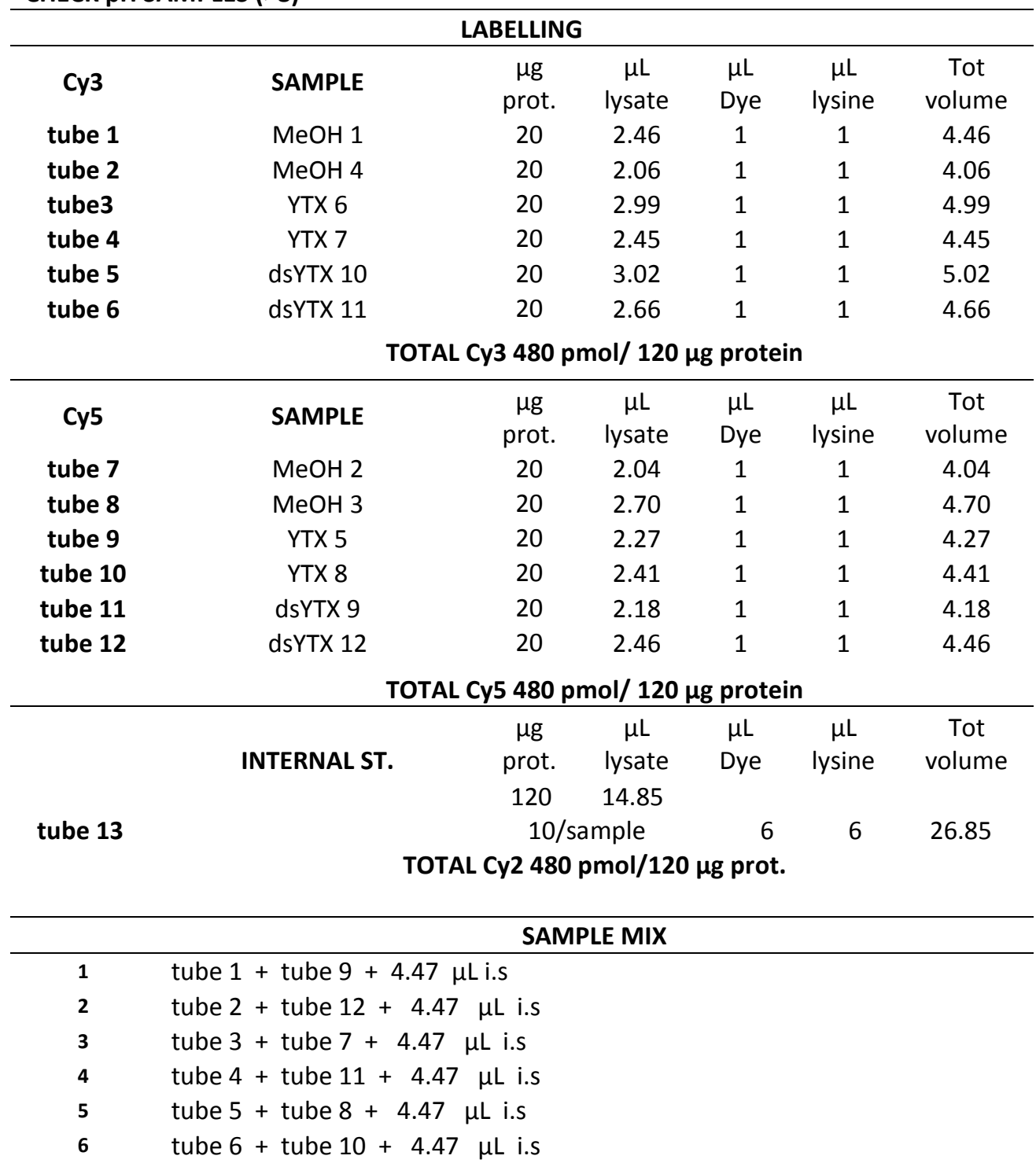




\begin{tabular}{|c|c|c|c|c|}
\hline & & & \multicolumn{2}{|c|}{$\mu L$ R.B. } \\
\hline & \multicolumn{2}{|c|}{ EXPERIMENT DESIGN } & pH 4-7 & pH 6-11 \\
\hline & & Су3 MeOH 1 & & \\
\hline \multirow[t]{3}{*}{1} & strip\# 11347 & Cy5 YTX 5 & 125 & 100 \\
\hline & & i.s.Cy2 & & \\
\hline & & Сy3 $\mathrm{MeOH} 4$ & & \\
\hline \multirow[t]{3}{*}{2} & strip\# 11349 & Cy5 dsYTX 12 & 125 & 100 \\
\hline & & i.s.Cy2 & & \\
\hline & & Су3 YTX 6 & & \\
\hline \multirow[t]{3}{*}{3} & strip\# 11350 & Cy5 MeOH 2 & 125 & 100 \\
\hline & & i.s.Cy2 & & \\
\hline & & Су3 YTX 7 & & \\
\hline \multirow[t]{3}{*}{4} & strip\# 11350 & Cy5 dsYTX 9 & 125 & 100 \\
\hline & & i.s.Cy2 & & \\
\hline & & Cy3 dsYTX 10 & & \\
\hline \multirow[t]{3}{*}{5} & strip\# 11350 & Cy5 MeOH 3 & 125 & 100 \\
\hline & & i.s.Cy2 & & \\
\hline & & Cy3 dsYTX 11 & & \\
\hline \multirow[t]{2}{*}{6} & strip\# 11350 & Cy5 YTX 8 & 125 & 100 \\
\hline & & i.s.Cy2 & & \\
\hline
\end{tabular}




\section{Appendix D}

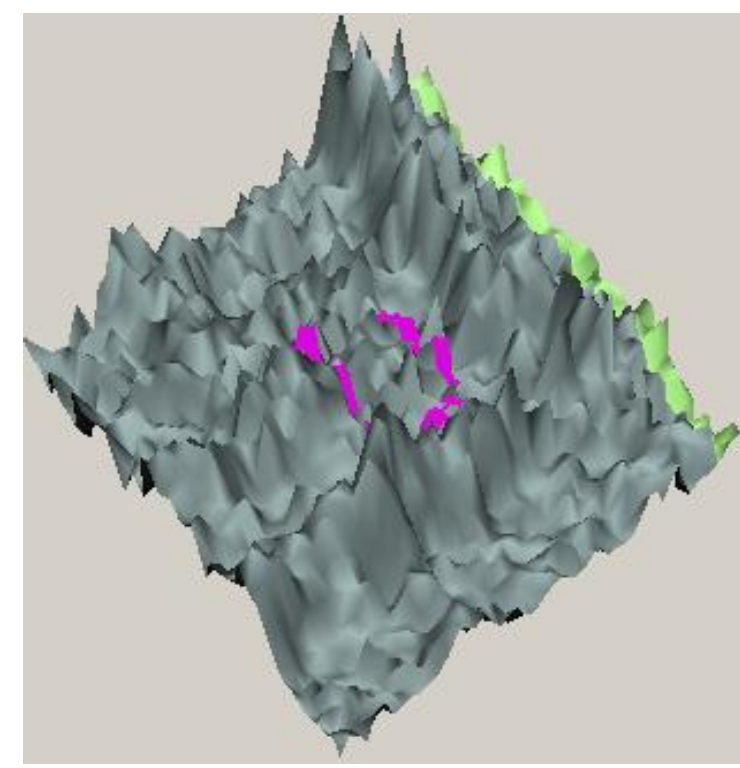

Example of "noise" 3D view

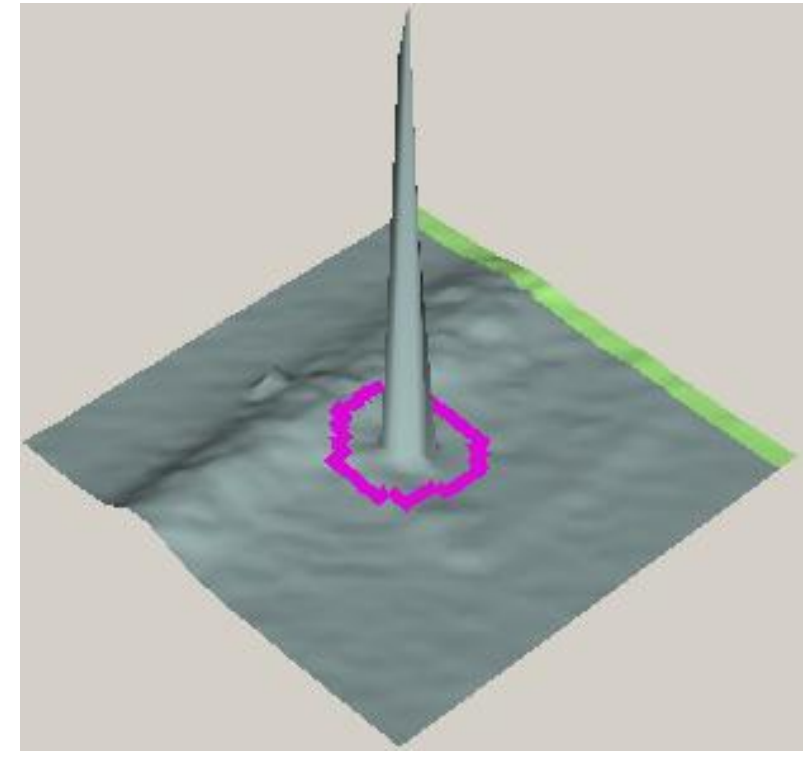

Example of dust 3D view

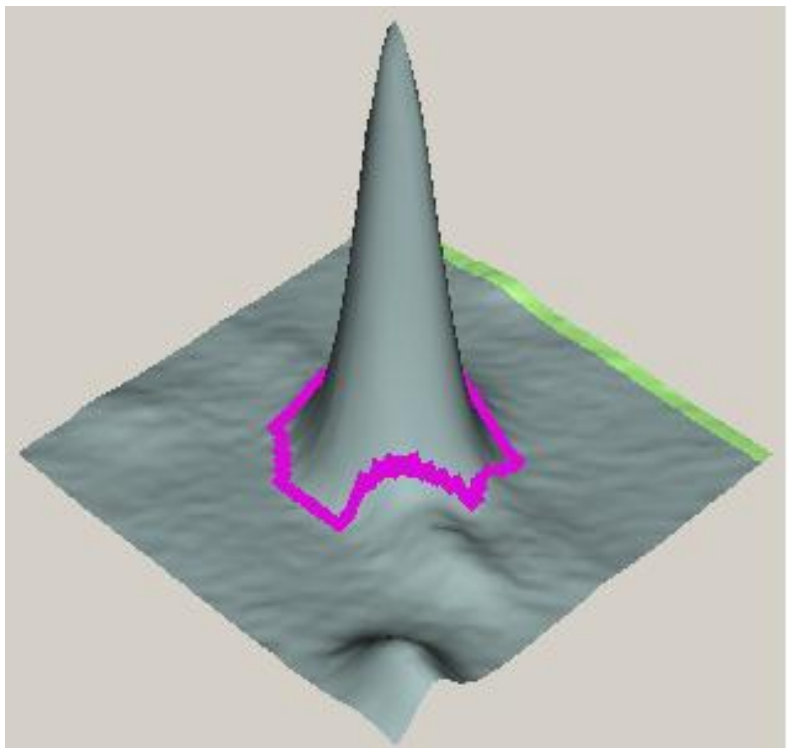

Example of a protein spot 3D view 


\section{Appendix E}

Reference masses for MS internal reflector positive procedural method

\begin{tabular}{|c|c|c|c|}
\hline m/z monoisotopic & NAME & TYPE & CHARGE \\
\hline 904.4680 & des-Arg1-bradykinin & $\mathrm{r}$ & +1 \\
\hline 1296.6850 & Angiotensin 1 & $\mathrm{r}$ & +1 \\
\hline 1570.6770 & Glu1-fibrinopeptide & $\mathrm{r}$ & +1 \\
\hline 2093.0870 & ACTH (1-17) & $\mathrm{r}$ & +1 \\
\hline 2465.1990 & ACTH (18-39) & $\mathrm{r}$ & +1 \\
\hline 3657.9294 & ACTH (7-38) & $\mathrm{r}$ & +1 \\
\hline
\end{tabular}

Reference masses for MS/MS internal reflector positive procedural method

\begin{tabular}{|c|c|c|c|}
\hline $\mathbf{m} / \mathbf{z}$ monoisotopic & NAME & TYPE & CHARGE \\
\hline 255.1090 & $\mathrm{~B} 2-17\left(-\mathrm{NH}_{3}\right)$ fragment ion & $\mathrm{r}$ & +1 \\
\hline 354.1780 & $\mathrm{~B} 3-17\left(-\mathrm{NH}_{3}\right)$ fragment ion & $\mathrm{r}$ & +1 \\
\hline 784.4110 & $\mathrm{~B} 6$ fragment ion & $\mathrm{r}$ & +1 \\
\hline 1181.6580 & Angiotensin Y9 fragment ion & $\mathrm{r}$ & +1 \\
\hline 1183.6010 & Angiotensin fragment ion & $\mathrm{r}$ & +1 \\
\hline
\end{tabular}




\section{Appendix F}

\section{Exclusion masses for MALDI TOF/TOF MS/MS}

\begin{tabular}{ccc}
\hline $\mathbf{m} / \mathbf{z}$ monoisotopic & NAME & TOLERANCE $(\mathbf{m} / \mathbf{z})$ \\
\hline 659.384 & Trypsin & 0.03 \\
805.417 & Trypsin & 0.03 \\
861.060 & CHCA & 0.10 \\
877.000 & Polyethylene glycol & 0.10 \\
906.505 & Trypsin & 0.03 \\
1020.503 & Trypsin & 0.03 \\
1153.574 & Trypsin & 0.03 \\
1175.523 & Trypsin & 0.03 \\
1296.680 & Angiotensin & 0.03 \\
1433.721 & Trypsin & 0.03 \\
1493.599 & Trypsin & 0.03 \\
1676.777 & Trypsin & 0.03 \\
1774.851 & Trypsin & 0.03 \\
2093.080 & ACTH (clip 1-17) & 0.03 \\
2163.057 & Trypsin & 0.03 \\
2193.003 & Trypsin & 0.03 \\
2193.995 & Trypsin & 0.03 \\
2273.160 & Trypsin & 0.03 \\
2289.155 & Trypsin & 0.03 \\
2305.150 & Trypsin & 0.03 \\
2465.190 & ACTH (clip 18-39) & 0.03 \\
2514.339 & Trypsin & 0.03 \\
2550.233 & Trypsin & 0.03 \\
2612.181 & Trypsin & 0.03 \\
2613.350 & Trypsin & 0.03 \\
3211.475 & Trypsin & 0.03 \\
3227.40 & Trypsin & 0.03 \\
\hline
\end{tabular}

Keller et al., 2008 


\section{Appendix G}

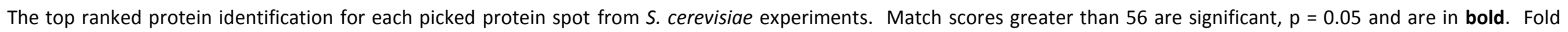

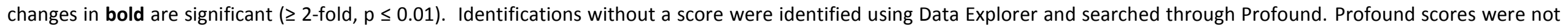

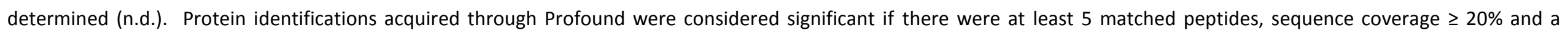
difference between first and second ranked identifications of at least $1 \times 10^{-3}$.

\begin{tabular}{|c|c|c|c|c|c|c|c|c|c|c|c|c|}
\hline \multirow{2}{*}{$\begin{array}{c}\text { Spot } \\
\#\end{array}$} & \multirow[b]{2}{*}{ Expt } & \multirow[b]{2}{*}{ Name } & \multirow[b]{2}{*}{ gi \# } & \multirow{2}{*}{$\begin{array}{c}\text { Calc. Mw } \\
\text { (kDa) }\end{array}$} & \multirow{2}{*}{$\begin{array}{c}\text { Calc. } \\
\text { pl }\end{array}$} & \multirow[b]{2}{*}{ Score } & \multirow[b]{2}{*}{ Expect. } & \multirow{2}{*}{$\begin{array}{l}\text { Seq. } \\
\text { cov. } \\
(\%)\end{array}$} & \multirow[b]{2}{*}{ Matched /total } & \multicolumn{3}{|c|}{ Fold change } \\
\hline & & & & & & & & & & $\begin{array}{c}\text { YTX/ } \\
\text { un }\end{array}$ & $\begin{array}{c}\text { YTX/ } \\
\text { MeOH }\end{array}$ & $\begin{array}{c}\mathrm{MeOH} / \\
\text { un }\end{array}$ \\
\hline 1 & $\begin{array}{c}\text { BY4741 } 1.2 \mu \mathrm{M}, \\
4-7\end{array}$ & $\begin{array}{l}\text { Formylglycinamidine-ribonucleotide } \\
\text { (FGAM)-synthetase, catalyses a step in } \\
\text { the 'de novo' purine nucleotide } \\
\text { biosynthetic pathway; Ade6p }\end{array}$ & gi|6321498 & 150.14 & 5.1 & n.d. & $8.9 \times 10^{-7}$ & 26 & $27 / 131$ & -1.3 & -1.1 & -1.18 \\
\hline 2 & $\begin{array}{c}\text { BY4741 } 1.2 \mu \mathrm{M}, \\
4-7\end{array}$ & SSE1 protein & gi|533365 & 77.68 & 5.1 & n.d. & $3.4 \times 10^{-5}$ & 36 & $21 / 93$ & -1.19 & -1.39 & 1.16 \\
\hline 5 & $\begin{array}{c}\text { BY4741 } 1.2 \mu \mathrm{M}, \\
4-7\end{array}$ & $\begin{array}{l}\text { Cytoplasmic tryptophanyl-tRNA } \\
\text { synthetase, aminoacylates } \\
\text { tryptophanyl-tRNA; Wrs1p }\end{array}$ & gi|6324475 & 49.661 & 6.35 & 28 & 31 & 12 & $5 / 45$ & -1.57 & -1.59 & 1.01 \\
\hline 9 & $\begin{array}{c}\text { BY4741 } 1.2 \mu \mathrm{M}, \\
4-7\end{array}$ & $\begin{array}{l}\text { Enolase II, catalyses the conversion of } \\
\text { 2-phosphoglycerate to } \\
\text { phosphoenolpyruvate during glycolysis } \\
\text { and the reverse reaction during } \\
\text { gluconeogenesis; Eno2p }\end{array}$ & gi|6321968 & 46.942 & 5.67 & 198 & $3.4 \mathrm{e}-016$ & 19 & $10 / 75$ & -1.32 & -1.33 & 1.01 \\
\hline 10 & $\begin{array}{c}\text { BY4741 } 1.2 \mu \mathrm{M}, \\
4-7\end{array}$ & $\begin{array}{l}\text { Cytosolic aldehyde dehydrogenase, } \\
\text { activated by Mg2+ and utilizes NADP+ } \\
\text { as the preferred coenzyme; required } \\
\text { for conversion of acetaldehyde to } \\
\text { acetate; constitutively expressed; } \\
\text { locates to the mitochondrial outer } \\
\text { surface upon oxidative stress; Ald6p }\end{array}$ & gi|6325196 & 54.80 & 5.3 & n.d. & $6.7 \times 10-4$ & 33 & $15 / 132$ & -1.51 & -1.44 & -1.05 \\
\hline
\end{tabular}




\begin{tabular}{|c|c|c|c|c|c|c|c|c|c|c|c|c|}
\hline \multirow{2}{*}{$\begin{array}{c}\text { Spot } \\
\#\end{array}$} & \multirow[b]{2}{*}{ Expt } & \multirow[b]{2}{*}{ Name } & \multirow[b]{2}{*}{ gi \# } & \multirow[b]{2}{*}{$\begin{array}{c}\text { Calc. Mw } \\
\text { (kDa) }\end{array}$} & \multirow[b]{2}{*}{$\begin{array}{c}\text { Calc. } \\
\text { pl }\end{array}$} & \multirow[b]{2}{*}{ Score } & \multirow[b]{2}{*}{ Expect. } & \multirow{2}{*}{$\begin{array}{l}\text { Seq. } \\
\text { cov. } \\
(\%)\end{array}$} & \multirow[b]{2}{*}{ Matched /total } & \multicolumn{3}{|c|}{ Fold change } \\
\hline & & & & & & & & & & $\begin{array}{c}\text { YTX/ } \\
\text { un }\end{array}$ & $\begin{array}{c}\text { YTX/ } \\
\text { MeOH }\end{array}$ & $\begin{array}{c}\text { MeOH/ } \\
\text { un }\end{array}$ \\
\hline 11 & $\begin{array}{c}\text { BY4741 } 1.2 \mu \mathrm{M}, \\
4-7\end{array}$ & cytosolic aldehyde dehydrogenase & gi|1336076 & 54.96 & 5.4 & n.d. & $8.9 \times 10-7$ & 49 & $23 / 99$ & -1.21 & -1.6 & 1.32 \\
\hline 12 & $\begin{array}{c}\text { BY4741 } 1.2 \mu \mathrm{M}, \\
4-7\end{array}$ & cytosolic aldehyde dehydrogenase & gi|1336076 & 54.96 & 5.4 & n.d. & $5.7 \times 10-7$ & 49 & $23 / 117$ & -1.24 & -1.29 & 1.05 \\
\hline 15 & $\begin{array}{c}\text { BY4741 } 1.2 \mu \mathrm{M}, \\
4-7\end{array}$ & $\begin{array}{c}\text { Threonine synthase, conserved } \\
\text { protein, catalyses formation of } \\
\text { threonine from } 0 \text { - } \\
\text { phosphohomoserine; Thr } 4 p\end{array}$ & gi|6319901 & 57.553 & 5.46 & 97 & 4.4e-006 & 17 & $10 / 64$ & -1.18 & -1.24 & 1.05 \\
\hline 16 & $\begin{array}{c}\text { BY4741 } 1.2 \mu \mathrm{M}, \\
4-7\end{array}$ & Aromatic aminotransferase I; Aro8p & gi|6321236 & 56.371 & 5.68 & 143 & $1.1 \mathrm{e}-010$ & 15 & $11 / 75$ & -1.03 & -1.15 & 1.12 \\
\hline 18 & $\begin{array}{c}\text { BY4741 } 1.2 \mu \mathrm{M}, \\
4-7\end{array}$ & $\begin{array}{l}\text { Enolase II, catalyses the conversion of } \\
\text { 2-phosphoglycerate to } \\
\text { phosphoenolpyruvate during } \\
\text { glycolysis and the reverse reaction } \\
\text { during gluconeogenesis; Eno2p }\end{array}$ & gi|6321968 & 46.942 & 5.67 & 194 & $8.5 e-016$ & 18 & $11 / 75$ & -1.07 & -1.19 & 1.11 \\
\hline \multirow{2}{*}{19} & \multirow{2}{*}{$\begin{array}{c}\text { BY4741 } 1.2 \mu \mathrm{M}, \\
4-7\end{array}$} & \multirow{2}{*}{$\begin{array}{l}\text { Enolase II, catalyses the conversion of } \\
\text { 2-phosphoglycerate to } \\
\text { phosphoenolpyruvate during } \\
\text { glycolysis and the reverse reaction } \\
\text { during gluconeogenesis; Eno2p }\end{array}$} & \multirow{2}{*}{ gi|6321968 } & \multirow{2}{*}{46.942} & \multirow{2}{*}{5.67} & 433 & $1.1 \mathrm{e}-039$ & 30 & $15 / 75$ & -1.12 & -1.21 & 1.08 \\
\hline & & & & & & 429 & 2.7e-039 & 34 & $18 / 75$ & -1.1 & -1.18 & 1.07 \\
\hline 20 & $\begin{array}{c}\text { BY4741 } 1.2 \mu \mathrm{M}, \\
4-7\end{array}$ & $\begin{array}{l}\text { Enolase II, catalyses the conversion of } \\
\text { 2-phosphoglycerate to } \\
\text { phosphoenolpyruvate during } \\
\text { glycolysis and the reverse reaction } \\
\text { during gluconeogenesis; Eno2p }\end{array}$ & gi|6321968 & 46.942 & 5.67 & 315 & $6.7 e-028$ & 29 & $15 / 75$ & -1.47 & -1.31 & -1.12 \\
\hline
\end{tabular}




\begin{tabular}{|c|c|c|c|c|c|c|c|c|c|c|c|c|}
\hline \multirow{2}{*}{$\begin{array}{c}\text { Spot } \\
\#\end{array}$} & \multirow[b]{2}{*}{ Expt } & \multirow[b]{2}{*}{ Name } & \multirow[b]{2}{*}{ gi \# } & \multirow{2}{*}{$\begin{array}{l}\text { Calc. Mw } \\
\text { (kDa) }\end{array}$} & \multirow{2}{*}{$\begin{array}{l}\text { Calc. } \\
\text { pl }\end{array}$} & \multirow[b]{2}{*}{ Score } & \multirow[b]{2}{*}{ Expect. } & \multirow{2}{*}{$\begin{array}{l}\text { Seq. } \\
\text { cov. } \\
(\%)\end{array}$} & \multirow[b]{2}{*}{ Matched /total } & \multicolumn{3}{|c|}{ Fold change } \\
\hline & & & & & & & & & & $\begin{array}{l}\text { YTX/ } \\
\text { un }\end{array}$ & $\begin{array}{l}\text { YTX/ } \\
\text { MeOH }\end{array}$ & $\begin{array}{c}\mathrm{MeOH} / \\
\text { un }\end{array}$ \\
\hline 23 & $\begin{array}{c}\text { BY4741 } 1.2 \mu \mathrm{M}, \\
4-7\end{array}$ & $\begin{array}{l}\text { Fructose } 1,6 \text {-bisphosphate aldolase, } \\
\text { required for glycolysis and } \\
\text { gluconeogenesis; catalyses conversion } \\
\text { of fructose } 1,6 \text { bisphosphate to } \\
\text { glyceraldehyde-3-P and } \\
\text { dihydroxyacetone-P; locates to } \\
\text { mitochondrial outer surface upon } \\
\text { oxidative stress; Fba1p }\end{array}$ & gi|6322790 & 39.881 & 5.51 & 123 & $1.1 \mathrm{e}-008$ & 14 & $8 / 75$ & -1.31 & -1.2 & -1.1 \\
\hline 25 & $\begin{array}{c}\text { BY4741 } 1.2 \mu \mathrm{M}, \\
4-7\end{array}$ & $\begin{array}{c}\text { Subunit d of the five-subunit V0 } \\
\text { integral membrane domain of } \\
\text { vacuolar H+-ATPase (V-ATPase), an } \\
\text { electrogenic proton pump found in } \\
\text { the endomembrane system; stabilizes } \\
\text { VO subunits; required for V1 domain } \\
\text { assembly on the vacuolar membrane; } \\
\text { Vma6p }\end{array}$ & gi|6323480 & 40.12 & 4.5 & n.d. & $6.2 \times 10^{-3}$ & 32 & $8 / 90$ & -1.16 & -1.2 & 1.04 \\
\hline 26 & $\begin{array}{c}\text { BY4741 } 1.2 \mu \mathrm{M}, \\
4-7\end{array}$ & $\begin{array}{c}\text { Chain A, Electrophilic Catalysis In } \\
\text { Triosephosphase Isomerase: The Role } \\
\text { Of Histidine-95 }\end{array}$ & gi|349951 & 26.75 & 5.6 & n.d. & $3.2 \times 10^{-4}$ & 47 & $11 / 87$ & 1.03 & -1.07 & 1.11 \\
\hline 28 & $\begin{array}{l}\text { BY4741 1.2 } \mu \mathrm{M}, \\
6-11\end{array}$ & $\begin{array}{c}\text { Chain A, Circularly Permuted } \\
\text { Phosphoglycerate Kinase; Pgk P72 }\end{array}$ & gi|157876436 & 44.595 & 7.71 & 401 & $1.7 e-036$ & 40 & $18 / 75$ & -1.03 & -1.07 & 1.04 \\
\hline 29 & $\begin{array}{c}\text { BY4741 } 1.2 \mu \mathrm{M}, \\
6-11\end{array}$ & $\begin{array}{c}\text { Chain A, Circularly Permuted } \\
\text { Phosphoglycerate Kinase; Pgk P72 }\end{array}$ & gi|157876436 & 44.595 & 7.71 & 369 & $2.7 e-033$ & 44 & $18 / 75$ & & & \\
\hline 32 & $\begin{array}{c}\text { BY4741 1.2 } \mu \mathrm{M}, \\
6-11 \\
\end{array}$ & $\begin{array}{c}\text { Chain E, Saccharomyces Cerevisiae } \\
\text { Phosphoglycerate Mutase }\end{array}$ & gi|157884466 & 26.687 & 8.27 & 335 & $6.7 e-030$ & 44 & $15 / 75$ & -1.75 & -1.64 & -1.06 \\
\hline 33 & $\begin{array}{c}\text { BY4741 } 1.2 \mu \mathrm{M}, \\
6-11\end{array}$ & $\begin{array}{l}\text { Protein component of the small (40S) } \\
\text { ribosomal subunit, the least basic of } \\
\text { the non-acidic ribosomal proteins; } \\
\text { phosphorylated in vivo; essential for } \\
\text { viability; Rps5p }\end{array}$ & gi|6322583 & 25.080 & 8.63 & 345 & $6.7 e-031$ & 35 & $16 / 75$ & -1.03 & 1.07 & -1.1 \\
\hline
\end{tabular}




\begin{tabular}{|c|c|c|c|c|c|c|c|c|c|c|c|c|}
\hline \multirow{2}{*}{$\begin{array}{c}\text { Spot } \\
\#\end{array}$} & \multirow[b]{2}{*}{ Expt } & \multirow[b]{2}{*}{ Name } & \multirow[b]{2}{*}{ gi \# } & \multirow[b]{2}{*}{$\begin{array}{c}\text { Calc. Mw } \\
\text { (kDa) }\end{array}$} & \multirow{2}{*}{$\begin{array}{c}\text { Calc. } \\
\text { pl }\end{array}$} & \multirow[b]{2}{*}{ Score } & \multirow[b]{2}{*}{ Expect. } & \multirow{2}{*}{$\begin{array}{l}\text { Seq. } \\
\text { cov. } \\
(\%)\end{array}$} & \multirow{2}{*}{$\begin{array}{c}\text { Matched } \\
\text { /total }\end{array}$} & \multicolumn{3}{|c|}{ Fold change } \\
\hline & & & & & & & & & & $\begin{array}{l}\text { (ds)YTX } \\
\text { /un }\end{array}$ & $\begin{array}{l}\text { (ds)YTX } \\
\text { /MeOH }\end{array}$ & $\begin{array}{c}\mathrm{MeOH} / \\
\text { un }\end{array}$ \\
\hline 41 & $\begin{array}{c}\text { BY4741 } 12 \mu \mathrm{M}, \\
4-7, \log \end{array}$ & unknown & gi|825555 & 22.362 & 5.10 & 37 & 4.6 & 17 & $5 / 23$ & 1.58 & 1.02 & 1.55 \\
\hline 43 & $\begin{array}{c}\text { BY4741 } 12 \mu \mathrm{M}, \\
4-7, \log \end{array}$ & YLL024Cp-like protein, AWRI1631 & gi|207343245 & 59.805 & 7.00 & 494 & $8.5 e-046$ & 28 & $21 / 75$ & 1.54 & -1.1 & 1.7 \\
\hline 45 & $\begin{array}{c}\text { BY4741 } 12 \mu \mathrm{M}, \\
4-7, \log \end{array}$ & unknown & gi|825555 & 22.362 & 5.10 & 22 & $1.4 \mathrm{e}+002$ & 17 & $6 / 56$ & 1.63 & 1.02 & 1.59 \\
\hline 49 & $\begin{array}{c}\text { BY4741 } 12 \mu \mathrm{M}, \\
4-7, \log \end{array}$ & $\begin{array}{c}\text { Chain A, The Structure Of Tap42 Alpha4 } \\
\text { Subunit }\end{array}$ & gi|152149535 & 27.360 & 5.58 & 20 & $2.3 e+002$ & 9 & $4 / 69$ & 1.75 & -1.06 & 1.86 \\
\hline 58 & $\begin{array}{c}\text { BY4741 } 12 \mu \mathrm{M}, \\
4-7, \log \end{array}$ & No hit & & & & & & & & 1.51 & 1 & 1.5 \\
\hline 66 & $\begin{array}{c}\text { BY4741 } 12 \mu \mathrm{M}, \\
4-7, \log \end{array}$ & No hit & & & & & & & & -1.5 & 1.06 & -1.6 \\
\hline 72 & $\begin{array}{l}\text { BY4741 } 12 \mu \mathrm{M}, \\
6-11, \log \end{array}$ & $\begin{array}{c}\text { hypothetical protein identified by } \\
\text { homology. See FEBS Letters [2000] } \\
\text { 487:31-36.; Pau9p }\end{array}$ & gi|13129151 & 4.521 & 9.52 & 23 & $1.1 \mathrm{e}+002$ & 52 & $2 / 75$ & 1.63 & -1.02 & 1.66 \\
\hline 88 & $\begin{array}{l}\text { BY4741 } 12 \mu \mathrm{M}, \\
6-11, \log \end{array}$ & $\operatorname{Ics} 2 p$ & gi|30267748 & 3.320 & 10.29 & 32 & 12 & 90 & $3 / 59$ & -1.56 & -1.1 & -1.42 \\
\hline 92 & $\begin{array}{c}\text { BY4741 } 12 \mu \mathrm{M}, \\
6-11, \log \end{array}$ & YNL022Cp-like protein AWRI1631 & gi|207341631 & 56.825 & 9.02 & 27 & 40 & 17 & $7 / 70$ & -1.52 & -1.01 & -1.51 \\
\hline 98 & $\begin{array}{l}\text { BY4741 } 12 \mu \mathrm{M} \\
6-11, \log \end{array}$ & $\begin{array}{l}\text { Thymidylate synthase, required for de } \\
\text { novo biosynthesis of pyrimidine } \\
\text { deoxyribonucleotides; expression is } \\
\text { induced at G1/S; Cdc21p }\end{array}$ & gi|83578104 & 35.310 & 6.67 & 26 & 52 & 19 & $7 / 67$ & -1.75 & 1.05 & -1.83 \\
\hline 113 & $\begin{array}{l}\text { BY4741 } 12 \mu \mathrm{M}, \\
6-11, \log \end{array}$ & Ydr381wp & gi|849202 & 11.932 & 10.72 & 26 & 56 & 42 & $6 / 75$ & -1.57 & -1.02 & -1.54 \\
\hline 123 & $\begin{array}{c}\text { BY4741 dsYTX, } \\
4-7\end{array}$ & $\begin{array}{l}\text { Hsp90 cochaperone, interacts with the } \\
\text { Ssa group of the cytosolic Hsp70 } \\
\text { chaperones; activates the ATPase } \\
\text { activity of Ssa1p; homolog of } \\
\text { mammalian Hop protein; Sti1p }\end{array}$ & gi|6324601 & 66.395 & 5.45 & 93 & $1.1 \mathrm{e}-005$ & 19 & $12 / 61$ & -1.01 & -1.02 & 1.01 \\
\hline
\end{tabular}




\begin{tabular}{|c|c|c|c|c|c|c|c|c|c|c|c|c|}
\hline \multirow{2}{*}{$\begin{array}{c}\text { Spot } \\
\#\end{array}$} & \multirow[b]{2}{*}{ Expt } & \multirow[b]{2}{*}{ Name } & \multirow[b]{2}{*}{ gi \# } & \multirow{2}{*}{$\begin{array}{l}\text { Calc. Mw } \\
\text { (kDa) }\end{array}$} & \multirow{2}{*}{$\begin{array}{l}\text { Calc. } \\
\text { pl }\end{array}$} & \multirow[b]{2}{*}{ Score } & \multirow[b]{2}{*}{ Expect. } & \multirow{2}{*}{$\begin{array}{l}\text { Seq. } \\
\text { cov. } \\
(\%)\end{array}$} & \multirow{2}{*}{$\begin{array}{l}\text { Matched } \\
\text { /total }\end{array}$} & \multicolumn{3}{|c|}{ Fold change } \\
\hline & & & & & & & & & & $\begin{array}{c}\text { dsYTX/ } \\
\text { un }\end{array}$ & $\begin{array}{l}\text { dsYTX/ } \\
\text { MeOH }\end{array}$ & $\begin{array}{c}\mathrm{MeOH} / \\
\text { un }\end{array}$ \\
\hline 127 & $\begin{array}{c}\text { BY4741 dsYTX, } \\
4-7\end{array}$ & $\begin{array}{l}\text { Thymidylate synthase, required for de } \\
\text { novo biosynthesis of pyrimidine } \\
\text { deoxyribonucleotides; expression is } \\
\text { induced at G1/S; Cdc21p }\end{array}$ & gi|83578104 & 35.310 & 6.67 & 30 & 20 & 22 & $8 / 75$ & 1.51 & 1.39 & 1.09 \\
\hline 136 & $\begin{array}{c}\text { BY4741 dsYTX, } \\
4-7\end{array}$ & $\begin{array}{l}\text { Phosphomannomutase, involved in } \\
\text { synthesis of GDP-mannose and } \\
\text { dolichol-phosphate-mannose; } \\
\text { required for folding and glycosylation } \\
\text { of secretory proteins in the ER lumen; } \\
\text { Sec53p }\end{array}$ & gi|14318474 & 29.216 & 5.14 & 124 & $8.5 e-009$ & 32 & $14 / 75$ & -1.02 & -1 & -1.01 \\
\hline 138 & $\begin{array}{c}\text { BY4741 dsYTX, } \\
4-7\end{array}$ & protein GRE1 RM11-1a & gi|190407740 & 18.926 & 4.60 & 113 & $1.1 \mathrm{e}-007$ & 42 & $8 / 75$ & -2.37 & -1.84 & -1.28 \\
\hline 142 & $\begin{array}{c}\text { BY4741 dsYTX, } \\
4-7\end{array}$ & $\begin{array}{l}\text { hypothetical protein identified by } \\
\text { homology. See FEBS Letters [2000] } \\
487: 31-36 . ; \text { Pau9p }\end{array}$ & gi|13129151 & 4.521 & 9.52 & 24 & 77 & 52 & $2 / 61$ & -1.52 & -1.39 & -1.09 \\
\hline 147 & $\begin{array}{c}\text { BY4741 dsYTX, } \\
4-7\end{array}$ & $\begin{array}{l}\text { Chain A, H48c Yeast } \mathrm{Cu}(\mathrm{li}) \mathrm{ZN} \\
\text { superoxide dismutase room } \\
\text { temperature (298k) Structure }\end{array}$ & gi|6730103 & 15.851 & 5.48 & 555 & $6.7 e-052$ & 60 & $13 / 75$ & -1.01 & 1.26 & -1.28 \\
\hline 150 & $\begin{array}{c}\text { BY4741 dsYTX, } \\
4-7\end{array}$ & $\begin{array}{c}\text { Chain G, Yeast Cytochrome Bc1 } \\
\text { Complex With Bound Substrate } \\
\text { Cytochrome C } \\
\end{array}$ & gi|20151124 & 14.482 & 5.63 & 68 & 0.0035 & 28 & $6 / 75$ & 1.34 & 1.18 & 1.13 \\
\hline 164 & AD $\Delta \mathrm{dsYTX}, 4-7$ & $\begin{array}{l}\text { Phosphatidylinositol transfer protein } \\
\text { (PITP) controlled by the multiple drug } \\
\text { resistance regulator Pdr1p, localizes to } \\
\text { lipid particles and microsomes, controls } \\
\text { levels of various lipids, may regulate } \\
\text { lipid synthesis, homologous to Pdr17p; } \\
\text { Pdr16p }\end{array}$ & gi|6324098 & 40.802 & 7.72 & 21 & $1.9 e+002$ & 13 & $5 / 67$ & 1.75 & 1.68 & 1.04 \\
\hline 165 & AD $\Delta$ dsYTX, 4-7 & YKR101Wp-like protein AWRI1631 & gi|207343311 & 69.792 & 9.04 & 19 & $2.4 \mathrm{e}+002$ & 12 & $6 / 69$ & 2.41 & 2.5 & -1.04 \\
\hline
\end{tabular}




\begin{tabular}{|c|c|c|c|c|c|c|c|c|c|c|c|c|}
\hline \multirow{2}{*}{$\begin{array}{c}\text { Spot } \\
\#\end{array}$} & \multirow[b]{2}{*}{ Expt } & \multirow[b]{2}{*}{ Name } & \multirow[b]{2}{*}{ gi \# } & \multirow{2}{*}{$\begin{array}{l}\text { Calc. Mw } \\
\text { (kDa) }\end{array}$} & \multirow{2}{*}{$\begin{array}{l}\text { Calc. } \\
\text { pl }\end{array}$} & \multirow[b]{2}{*}{ Score } & \multirow[b]{2}{*}{ Expect. } & \multirow{2}{*}{$\begin{array}{l}\text { Seq. } \\
\text { cov. } \\
(\%)\end{array}$} & \multirow{2}{*}{$\begin{array}{l}\text { Matched } \\
\text { /total }\end{array}$} & \multicolumn{3}{|c|}{ Fold change } \\
\hline & & & & & & & & & & $\begin{array}{c}\text { dsYTX/ } \\
\text { un }\end{array}$ & $\begin{array}{l}\text { dsYTX/ } \\
\text { MeOH }\end{array}$ & $\begin{array}{c}\mathrm{MeOH} / \\
\text { un }\end{array}$ \\
\hline 166 & $\mathrm{AD} \Delta \mathrm{dsYTX}, 4-7$ & $\begin{array}{c}\text { hypothetical protein identified by } \\
\text { homology. See FEBS Letters [2000] } \\
\text { 487:31-36.; Pau9p }\end{array}$ & gi|13129151 & 4.521 & 9.52 & 24 & 85 & 52 & $2 / 64$ & 2.04 & 2.06 & -1.01 \\
\hline 168 & $\mathrm{AD} \Delta \mathrm{dsYTX}, 4-7$ & $\begin{array}{l}\text { Chain A, Crystal Structure Of An } \\
\text { Hsp90-Sba1 Closed Chaperone } \\
\text { Complex }\end{array}$ & gi|99031945 & 77.927 & 5.06 & 95 & $6.6 e-006$ & 8 & $8 / 75$ & 1.61 & 1.66 & -1.03 \\
\hline 170 & $\mathrm{AD} \Delta \mathrm{dsYTX}, 4-7$ & $\begin{array}{c}\text { Chain A, Crystal Structure Analysis Of } \\
\text { Sse1, A Yeast Hsp110 }\end{array}$ & gi|159795398 & 73.710 & 5.17 & 24 & 89 & 5 & $4 / 70$ & 1.78 & 1.89 & -1.06 \\
\hline 173 & AD $\triangle$ dsYTX, 4-7 & YLL024Cp-like protein AWRI1631 & gi|207343245 & 59.805 & 7.00 & 280 & $2.1 \mathrm{e}-024$ & 23 & $16 / 75$ & 1.85 & 2.04 & -1.1 \\
\hline 177 & $\mathrm{AD} \Delta \mathrm{dsYTX}, 4-7$ & $\begin{array}{c}\text { hypothetical protein identified by } \\
\text { homology. See FEBS Letters [2000] } \\
\text { 487:31-36.; Pau9p }\end{array}$ & gi|13129151 & 4.521 & 9.52 & 23 & $1.1 \mathrm{e}+002$ & 52 & $2 / 75$ & 1.95 & 1.82 & 1.07 \\
\hline 181 & $\mathrm{AD} \Delta \mathrm{dsYTX}, 4-7$ & $\begin{array}{c}\text { hypothetical protein identified by } \\
\text { homology. See FEBS Letters [2000] } \\
\text { 487:31-36.; Pau9p }\end{array}$ & gi|13129151 & 4.521 & 9.52 & 23 & $1.1 \mathrm{e}+002$ & 52 & $2 / 75$ & 1.5 & 1.66 & -1.1 \\
\hline 184 & $\mathrm{AD} \Delta \mathrm{dsYTX}, 4-7$ & $\begin{array}{l}\text { One of six ATPases of the } 19 \mathrm{~S} \\
\text { regulatory particle of the } 26 \mathrm{~S} \\
\text { proteasome involved in the } \\
\text { degradation of ubiquitinated } \\
\text { substrates; bound by ubiquitin-protein } \\
\text { ligases Ubr1p and Ufd4p; localized } \\
\text { mainly to the nucleus throughout the } \\
\text { cell cycle; Rpt6p }\end{array}$ & gi|6321390 & 45.471 & 9.09 & 19 & $2.5 e+002$ & 14 & $4 / 72$ & 1.6 & 1.82 & -1.14 \\
\hline 188 & AD $\triangle$ dsYTX, 4-7 & YLL024Cp-like protein AWRI1631 & gi|207343245 & 59.805 & 7.00 & 92 & $1.3 e-005$ & 13 & $11 / 74$ & 1.31 & 1.26 & 1.04 \\
\hline 190 & AD $\triangle$ dsYTX, 4-7 & actin & gi|3328 & 41.907 & 5.53 & 98 & $3.3 e-006$ & 14 & $9 / 52$ & 1.27 & 1.36 & -1.08 \\
\hline 191 & $\mathrm{AD} \Delta \mathrm{dsYTX}, 4-7$ & YGL071Wp-like protein AWRI1631 & gi|207345331 & 51.776 & 5.74 & 31 & 16 & 14 & $9 / 75$ & 1.63 & 1.65 & -1.01 \\
\hline 200 & $\mathrm{AD} \Delta \mathrm{dsYTX}, 4-7$ & $\begin{array}{c}\text { mitochondrial translational activator } \\
\text { [Saccharomyces cerevisiae YJM789] }\end{array}$ & gi|151944573 & 57707 & 9.18 & 25 & 67 & $15 \%$ & $7 / 75$ & -2.26 & -2.36 & 1.04 \\
\hline 201 & AD $\Delta$ dsYTX, 4-7 & conserved protein YJM789 & gi|151942578 & 18.896 & 4.60 & 168 & $3.4 \mathrm{e}-013$ & 34 & $8 / 63$ & 1.16 & 1.15 & 1.01 \\
\hline 205 & $\mathrm{AD} \Delta \mathrm{dsYTX}, 4-7$ & $\begin{array}{c}\text { Putative protein of unknown function; } \\
\text { YIr146w-ap }\end{array}$ & gi|82795259 & 7.130 & 4.75 & 24 & 87 & 37 & $4 / 75$ & -1.7 & -1.81 & 1.06 \\
\hline
\end{tabular}




\begin{tabular}{|c|c|c|c|c|c|c|c|c|c|c|c|c|}
\hline \multirow{2}{*}{$\begin{array}{c}\text { Spot } \\
\#\end{array}$} & \multirow[b]{2}{*}{ Expt } & \multirow[b]{2}{*}{ Name } & \multirow[b]{2}{*}{ gi \# } & \multirow{2}{*}{$\begin{array}{l}\text { Calc. Mw } \\
\text { (kDa) }\end{array}$} & \multirow{2}{*}{$\begin{array}{c}\text { Calc. } \\
\text { pl }\end{array}$} & \multirow[b]{2}{*}{ Score } & \multirow[b]{2}{*}{ Expect. } & \multirow{2}{*}{$\begin{array}{l}\text { Seq. } \\
\text { cov. } \\
(\%)\end{array}$} & \multirow{2}{*}{$\begin{array}{c}\text { Matched } \\
\text { /total }\end{array}$} & \multicolumn{3}{|c|}{ Fold change } \\
\hline & & & & & & & & & & $\begin{array}{c}\text { dsYTX/ } \\
\text { un }\end{array}$ & $\begin{array}{l}\text { dsYTX/ } \\
\text { MeOH }\end{array}$ & $\begin{array}{c}\text { MeOH/ } \\
\text { un }\end{array}$ \\
\hline 206 & $\mathrm{AD} \Delta \mathrm{dsYTX}, 4-7$ & $\begin{array}{l}\text { One of six subunits of the RNA } \\
\text { polymerase III transcription initiation } \\
\text { factor complex (TFIIIC); part of the } \\
\text { TauA globular domain of TFIIIC that } \\
\text { binds DNA at the BoxA promoter sites } \\
\text { of tRNA and similar genes; human } \\
\text { homolog is TFIIIC-63; Tfc1p }\end{array}$ & gi|6319600 & 73.678 & 5.23 & 24 & 85 & 14 & $8 / 71$ & -1.37 & -1.53 & 1.11 \\
\hline 207 & AD $\Delta \mathrm{dsYTX}, 4-7$ & $\begin{array}{c}\text { Chain G, Yeast Cytochrome Bc1 } \\
\text { Complex With Bound Substrate } \\
\text { Cytochrome C } \\
\end{array}$ & gi|20151124 & 14.482 & 5.63 & 79 & 0.00026 & 28 & $6 / 75$ & 1.06 & 1.12 & -1.07 \\
\hline 208 & AD $\Delta$ dsYTX, 4-7 & YGR254Wp-like protein AWRI1631 & gi|207344913 & 41.740 & 6.23 & 94 & $8.1 e-006$ & 8 & $3 / 75$ & -1.28 & -1.42 & 1.11 \\
\hline 209 & $\mathrm{AD} \Delta \mathrm{dsYTX}, 4-7$ & YGR254Wp-like protein AWRI1631 & gi|207344913 & 41.740 & 6.23 & 120 & $2.1 \mathrm{e}-008$ & 4 & $2 / 31$ & -1.45 & -1.65 & 1.14 \\
\hline 211 & $\mathrm{AD} \Delta \mathrm{dsYTX}, 4-7$ & dehydrogenase isozyme I, alcohol & gi|223142 & 31.954 & 6.38 & 84 & $8.1 e-005$ & 12 & $6 / 75$ & -1.49 & -1.54 & 1.03 \\
\hline 215 & $\begin{array}{c}\mathrm{AD} \Delta \mathrm{dsYTX}, 6- \\
11\end{array}$ & $\begin{array}{l}\text { Translational elongation factor EF-1 } \\
\text { alpha; also encoded by TEF1; functions } \\
\text { in the binding reaction of aminoacyl- } \\
\text { tRNA (AA-tRNA) to ribosomes; Tef2p }\end{array}$ & gi|6319594 & 50.400 & 9.14 & 112 & $1.3 e-007$ & 13 & $10 / 75$ & 1.69 & 2.1 & -1.24 \\
\hline 217 & $\begin{array}{c}\text { AD } \Delta \text { dsYTX, 6- } \\
11 \\
\end{array}$ & unnamed protein product & gi|395245 & 12.862 & 10.33 & 20 & $2.3 e+002$ & 21 & $3 / 75$ & & & \\
\hline 218 & $\begin{array}{c}\text { AD } \Delta \text { dsYTX, 6- } \\
11\end{array}$ & pyruvate kinase & gi|4180 & 54.964 & 8.00 & 197 & $4.3 e-016$ & 14 & $14 / 75$ & -1.11 & -1.14 & 1.03 \\
\hline 219 & $\begin{array}{c}\text { AD } \Delta \text { dsYTX, 6- } \\
11 \\
\end{array}$ & $\begin{array}{l}\text { Alcohol dehydrogenase isoenzyme } \mathrm{V} ; \\
\text { involved in ethanol production; Adh5p }\end{array}$ & gi|6319621 & 38.194 & 5.94 & 31 & 15 & 5 & $3 / 72$ & -1.59 & -1.82 & 1.15 \\
\hline 220 & $\begin{array}{c}\mathrm{AD} \Delta \mathrm{dsYTX}, 6- \\
11 \\
\end{array}$ & pyruvate kinase & gi|4180 & 54.964 & 8.00 & 341 & $1.7 e-030$ & 17 & $19 / 75$ & -1.33 & -1.49 & 1.12 \\
\hline
\end{tabular}




\section{Appendix H}

Proteins identified as not having a significant change of abundance by 2D-DIGE analysis of YTX in S. cerevisiae.

\begin{tabular}{|c|c|c|}
\hline Experiment & Protein name & $\begin{array}{l}\text { Spot } \\
\text { number(s) }\end{array}$ \\
\hline BY4741, 1.2 $\mu \mathrm{M}$ YTX & FGAM-synthetase & 1 \\
\hline BY4741, 1.2 $\mu \mathrm{M}$ YTX & SSE1 protein (ATPase component of HSP90 cochaperone complex) & 2 \\
\hline BY4741, $1.2 \mu \mathrm{M}$ YTX & Enolase II & $9,18-20$ \\
\hline BY4741, 1.2 $\mu \mathrm{M}$ YTX & Cytosolic aldehyde dehydrogenase & 11,12 \\
\hline BY4741, 1.2 $\mu \mathrm{M}$ YTX & Threonine synthase & 15 \\
\hline BY4741, $1.2 \mu \mathrm{M}$ YTX & Aromatic aminotransferase I & 16 \\
\hline BY4741, $1.2 \mu \mathrm{M}$ YTX & Fructose 1,6-biphosphate aldolase & 22 \\
\hline BY4741, 1.2 $\mu \mathrm{M}$ YTX & V0 integral membrane domain of vacuolar $\mathrm{H}^{+}$-ATPase, subunit $\mathrm{d}$ & 25 \\
\hline BY4741, 1.2 $\mu \mathrm{M}$ YTX & Electrophilic catalysis in triosephophate isomerase, chain A & 26 \\
\hline $\begin{array}{l}\text { BY4741, } 1.2 \mu \mathrm{M} \text { YTX; } \\
\text { AD } \Delta \text { dsYTX }\end{array}$ & Pyruvate kinase & $\begin{array}{l}27,218, \\
220\end{array}$ \\
\hline BY4741, 1.2 $\mu \mathrm{M}$ YTX & Circularly permuted phosphoglycerate kinase, chain A & 28,29 \\
\hline BY4741, 1.2 $\mu \mathrm{M}$ YTX & Protein component of small ribosomal subunit & 33 \\
\hline $\begin{array}{l}\text { BY4741, } 12 \mu \mathrm{M} \text { YTX, } \\
\text { log phase; } \\
\text { AD } \Delta \text { dsYTX }\end{array}$ & YYL024Cp-like protein & $\begin{array}{l}43,62, \\
188\end{array}$ \\
\hline $\begin{array}{l}\text { BY4741, } 12 \mu \mathrm{M} \text { YTX, } \\
\text { log phase }\end{array}$ & ATPase & 44 \\
\hline $\begin{array}{l}\text { BY4741, } 12 \mu \mathrm{M} \text { YTX, } \\
\text { log phase }\end{array}$ & Nucleoside diphosphate kinase & 96 \\
\hline BY4741 dsYTX & HSP90 cochaperone & 123 \\
\hline BY4741 dsYTX & Phosphomannomutase & 136 \\
\hline BY4741 dsYTX & Egd2p & 137 \\
\hline BY4741 dsYTX & Yeast $\mathrm{Cu}(\mathrm{Li}) \mathrm{Zn}$ superoxide dismutase & 147 \\
\hline $\begin{array}{l}\text { BY4741 dsYTX; } \\
\text { AD } \Delta \text { dsYTX }\end{array}$ & Cytochrome Bcl complex & 150, 207 \\
\hline ADS dsYTX & Actin & 190 \\
\hline ADS dsYTX & Conserved protein, YJM789 & 201 \\
\hline ADS dsYTX & YGR254Wp-like protein & 208,209 \\
\hline
\end{tabular}




\section{Appendix I}

The top ranked protein identification for each picked protein spots from HL60 experiment which showed at least a 1.5 -fold change in abundance, $\mathrm{p}$-value $=0.05$. Match scores greater than 66 are significant, $p=0.05$ and are in bold. *Indicates a protein identification which is the best match overall (including Mw, pl), but is not the top-ranked identification. Fold changes in bold are significant ( $\geq 2$-fold, $p \leq 0.01$ ).

\begin{tabular}{|c|c|c|c|c|c|c|c|c|c|c|c|c|}
\hline \multirow[b]{2}{*}{$\begin{array}{c}\text { Spot } \\
\#\end{array}$} & \multirow[b]{2}{*}{ pH } & \multirow[b]{2}{*}{ Name } & \multirow[b]{2}{*}{ gi \# } & \multirow[b]{2}{*}{$\begin{array}{l}\text { Calc. Mw } \\
\text { (kDa) }\end{array}$} & \multirow[b]{2}{*}{$\begin{array}{c}\text { Calc. } \\
\text { pl }\end{array}$} & \multirow[b]{2}{*}{ Score } & \multirow[b]{2}{*}{ Expect. } & \multirow[b]{2}{*}{$\begin{array}{c}\text { Seq. cov. } \\
\text { (\%) }\end{array}$} & \multirow[b]{2}{*}{$\begin{array}{c}\text { Matched } \\
\text { /total }\end{array}$} & \multicolumn{3}{|c|}{ Fold change } \\
\hline & & & & & & & & & & $\begin{array}{l}\text { YTX/ } \\
\text { MeOH }\end{array}$ & $\begin{array}{l}\text { dsYTX/ } \\
\text { MeOH }\end{array}$ & $\begin{array}{c}\text { dsYTX/ } \\
\text { YTX }\end{array}$ \\
\hline 1 & $4-7$ & $\begin{array}{l}\text { Immunoglobulin heavy chain } \\
\text { variable region }\end{array}$ & gi|112699019 & 10.962 & 7.88 & 34 & 95 & $40 \%$ & $3 / 65$ & 1.87 & 2.13 & 1.14 \\
\hline \multirow[b]{2}{*}{2} & \multirow[b]{2}{*}{$4-7$} & tumour rejection antigen (gp96) 1 & gi|61656607 & 92.567 & 4.77 & 71 & 0.018 & $10 \%$ & $14 / 75$ & \multirow[b]{2}{*}{1.27} & \multirow[b]{2}{*}{1.63} & \multirow[b]{2}{*}{1.28} \\
\hline & & $\begin{array}{c}\text { heat shock protein 90kDa beta, } \\
\text { member } 1\end{array}$ & gi|4507677 & 92.696 & 4.76 & 71 & 0.018 & $10 \%$ & $14 / 75$ & & & \\
\hline \multirow{2}{*}{4} & \multirow{2}{*}{$4-7$} & \multirow{2}{*}{$\begin{array}{l}\text { opioid growth factor receptor } \\
\text { and/or S100 calcium-binding } \\
\text { protein A8 }\end{array}$} & gi| 66347254 & 11.600 & 5.54 & 44 & 9.3 & $32 \%$ & $5 / 75$ & \multirow{2}{*}{1.4} & \multirow{2}{*}{1.55} & \multirow{2}{*}{1.1} \\
\hline & & & gi|21614544 & 10.885 & 6.51 & 36 & 62 & $43 \%$ & $6 / 75$ & & & \\
\hline 5 & $4-7$ & MHC class I antigen & gi|85815622 & 10.392 & 5.30 & 35 & 76 & $46 \%$ & $4 / 64$ & 1.61 & 2.02 & 1.26 \\
\hline 7 & $4-7$ & hCG2015481 & gi|119618893 & 7.512 & 9.04 & 24 & $7.9 e+002$ & $43 \%$ & $3 / 75$ & 2.37 & 2.9 & 1.22 \\
\hline 8 & $4-7$ & $\begin{array}{l}\text { hCG2044129 \{region: DUF132, } \\
\text { contains SGF29 tudor-like domain; } \\
\text { pfam07039; poss RNA binding\} }\end{array}$ & gi|119572656 & 6.273 & 6.31 & 36 & 50 & $24 \%$ & $2 / 7$ & 1.88 & 2.31 & 1.23 \\
\hline \multirow{3}{*}{$\begin{array}{c}9 \\
10 \\
11\end{array}$} & \multirow{3}{*}{$4-7$} & \multirow{3}{*}{ GRP78 precursor } & \multirow{3}{*}{ gi|386758 } & \multirow{3}{*}{72.185} & \multirow{3}{*}{5.03} & \multirow{3}{*}{446} & \multirow{3}{*}{$5.5 e-040$} & \multirow{3}{*}{$30 \%$} & \multirow{3}{*}{$23 / 75$} & 1.65 & 2.07 & 1.25 \\
\hline & & & & & & & & & & 1.49 & 1.82 & 1.22 \\
\hline & & & & & & & & & & 1.44 & 1.7 & 1.18 \\
\hline 12 & $4-7$ & BiP protein & gi|6470150 & 71.002 & 5.23 & 145 & $6.9 e-010$ & $16 \%$ & $12 / 75$ & 1.54 & 1.8 & 1.17 \\
\hline 13 & $4-7$ & $\begin{array}{l}\text { PRO1095 \{predicted protein } \\
\text { product of } \mathrm{HQ1095} \text { \} }\end{array}$ & gi|11493413 & 4.854 & 9.59 & 29 & $2.8 \mathrm{e}+002$ & $57 \%$ & $4 / 42$ & 1.99 & 2.57 & 1.3 \\
\hline 18 & $4-7$ & unnamed protein product & gi|193786969 & 99.132 & 7.32 & 39 & 26 & $4 \%$ & $5 / 12$ & -1.62 & 1.95 & -1.2 \\
\hline 19 & $4-7$ & $\begin{array}{l}\text { unnamed protein product \{contains } \\
\text { Ribosomal L3 superfamily domain; } \\
\text { highly similar to mitochondrial 39s } \\
\text { ribosomal protein L3\} }\end{array}$ & gi|194376318 & 27.262 & 9.64 & 48 & 3.8 & $16 \%$ & $4 / 14$ & -1.37 & -1.7 & -1.24 \\
\hline
\end{tabular}




\begin{tabular}{|c|c|c|c|c|c|c|c|c|c|c|c|c|}
\hline \multirow[b]{2}{*}{$\begin{array}{c}\text { Spot } \\
\#\end{array}$} & \multirow[b]{2}{*}{$\mathrm{pH}$} & \multirow[b]{2}{*}{ Name } & \multirow[b]{2}{*}{ gi \# } & \multirow[b]{2}{*}{$\begin{array}{c}\text { Calc. Mw } \\
\text { (kDa) }\end{array}$} & \multirow[b]{2}{*}{$\begin{array}{c}\text { Calc. } \\
\text { pl }\end{array}$} & \multirow[b]{2}{*}{ Score } & \multirow[b]{2}{*}{ Expect. } & \multirow[b]{2}{*}{$\begin{array}{c}\text { Seq. cov. } \\
\text { (\%) }\end{array}$} & \multirow[b]{2}{*}{$\begin{array}{c}\text { Matched } \\
\text { /total }\end{array}$} & \multicolumn{3}{|c|}{ Fold change } \\
\hline & & & & & & & & & & $\begin{array}{c}\text { YTX/ } \\
\text { MeOH }\end{array}$ & $\begin{array}{c}\text { dsYTX/ } \\
\text { MeOH }\end{array}$ & dsYTX/YTX \\
\hline 20 & $4-7$ & $\begin{array}{l}\text { hCG2040114, isoform CRA_b } \\
\text { \{ch/some 2 }\end{array}$ & gi|119620565 & 15.179 & 8.56 & 31 & $1.8 \mathrm{e}+002$ & $29 \%$ & $3 / 34$ & -1.63 & -2.04 & -1.25 \\
\hline 21 & $4-7$ & hCG2042223 \{ch/some 1\} & gi|119615331 & 8.095 & 11.92 & 50 & 2 & $38 \%$ & $3 / 11$ & -1.59 & -1.63 & -1.02 \\
\hline 22 & $4-7$ & $\begin{array}{l}\text { translation initiation factor elF- } \\
\text { 4gamma }\end{array}$ & gi|510307 & 79.884 & 5.44 & 35 & 6 & $5 \%$ & $4 / 11$ & -2.81 & -2.58 & 1.09 \\
\hline 23 & $4-7$ & $\begin{array}{l}\text { cytotoxic T-lymphocyte-associated } \\
\text { protein } 4\end{array}$ & gi|553245 & 4.397 & 9.61 & 39 & 29 & $50 \%$ & $4 / 44$ & -2.68 & -2.55 & 1.05 \\
\hline 24 & $4-7$ & ferritin light polypeptide & gi|171702799 & 5.863 & 5.74 & 31 & $1.9 e+002$ & $44 \%$ & $4 / 75$ & 1.49 & 2.1 & 1.41 \\
\hline 25 & $4-7$ & $\begin{array}{l}\text { immunoglobulin lambda chain } \\
\text { variable region }\end{array}$ & gi|3153364 & 11.031 & 9.07 & 44 & 8.9 & $43 \%$ & $3 / 41$ & 1.65 & 2.38 & 1.44 \\
\hline 28 & $4-7$ & hCG2012006 \{ch/some 2\} & gi|119590542 & 3.398 & 9.39 & 34 & 85 & $51 \%$ & $3 / 62$ & 2.05 & 2.55 & 1.24 \\
\hline 29 & $4-7$ & $\begin{array}{l}\text { heat shock 60kDa protein } 1 \\
\text { (chaperonin), isoform CRA_c }\end{array}$ & gi|119590557 & 41.067 & 5.09 & 47 & 4.8 & $16 \%$ & $7 / 75$ & 2.12 & 2.89 & 1.36 \\
\hline 30 & $4-7$ & $\begin{array}{l}\text { heat shock 60kDa protein } 1 \\
\text { (chaperonin), isoform CRA_c }\end{array}$ & gi|119590557 & 41.067 & 5.09 & 67 & 0.04 & $21 \%$ & $11 / 75$ & 1.86 & 2.54 & 1.37 \\
\hline 31 & $4-7$ & $\begin{array}{l}\text { immunoglobulin heavy chain } \\
\text { variable region }\end{array}$ & gi|11137459 & 11.216 & 10.01 & 34 & 81 & $58 \%$ & $5 / 66$ & 1.53 & 2 & 1.31 \\
\hline 32 & $4-7$ & $\begin{array}{l}\text { unnamed protein product } \\
\text { \{GroEL/chaperonin type } \\
\text { I/II/chaperonin like domain. } \\
\text { Chaperonins are involved in } \\
\text { productive folding of proteins\} }\end{array}$ & gi|221041730 & 58.705 & 5.82 & 52 & 1.2 & $7 \%$ & $10 / 75$ & 1.22 & 1.57 & 1.28 \\
\hline 34 & $4-7$ & $\begin{array}{l}\text { hCG2030305, isoform CRA_a } \\
\text { \{ch/some 6 }\end{array}$ & gi|119568344 & 6.997 & 9.77 & 29 & $3 e+002$ & $24 \%$ & $2 / 15$ & 1.75 & 2.1 & 1.2 \\
\hline 35 & $4-7$ & calreticulin precursor variant & gi|62897681 & 47.061 & 4.30 & 31 & $1.8 \mathrm{e}+002$ & $11 \%$ & $9 / 75$ & 1.31 & 1.56 & 1.19 \\
\hline 39 & $4-7$ & NOS1 protein & gi|118600892 & 10.454 & 5.08 & 40 & 25 & $45 \%$ & $4 / 41$ & -1.76 & -1.79 & -1.02 \\
\hline 41 & $4-7$ & $\begin{array}{c}\text { unnamed protein product \{non- } \\
\text { specific hit to NAD-dependent } \\
\text { glycerol-3-phosphate } \\
\text { dehydrogenase C-terminus } \\
\text { domain\} }\end{array}$ & gi|193785041 & 13.475 & 7.63 & 35 & 66 & $18 \%$ & $4 / 42$ & -1.57 & -1.77 & -1.13 \\
\hline
\end{tabular}




\begin{tabular}{|c|c|c|c|c|c|c|c|c|c|c|c|c|}
\hline \multirow{2}{*}{$\begin{array}{c}\text { Spot } \\
\#\end{array}$} & \multirow[b]{2}{*}{$\mathrm{pH}$} & \multirow[b]{2}{*}{ Name } & \multirow[b]{2}{*}{ gi \# } & \multirow{2}{*}{$\begin{array}{l}\text { Calc. Mw } \\
\text { (kDa) }\end{array}$} & \multirow[b]{2}{*}{ Calc. pl } & \multirow[b]{2}{*}{ Score } & \multirow[b]{2}{*}{ Expect. } & \multirow[b]{2}{*}{$\begin{array}{l}\text { Seq. cov. } \\
\text { (\%) }\end{array}$} & \multirow[b]{2}{*}{$\begin{array}{l}\text { Matched } \\
\text { /total }\end{array}$} & \multicolumn{3}{|c|}{ Fold change } \\
\hline & & & & & & & & & & $\begin{array}{l}\text { YTX/ } \\
\text { MeOH }\end{array}$ & $\begin{array}{l}\text { dsYTX/ } \\
\text { MeOH }\end{array}$ & dsYTX/YTX \\
\hline 45 & $4-7$ & KRT8 protein & gi|14198278 & 30.802 & 5.02 & 26 & $5.5 e+002$ & $21 \%$ & $4 / 31$ & 2.02 & 2.81 & 1.39 \\
\hline 46 & $4-7$ & zinc finger protein 441 & gi|119604646 & 78.130 & 8.95 & 38 & 32 & $9 \%$ & $6 / 20$ & 2.34 & 3.55 & 1.51 \\
\hline 50 & $4-7$ & tyrosine hydroxylase & gi|548153 & 3.717 & 8.31 & 36 & 55 & $73 \%$ & $3 / 15$ & 2.53 & 2.42 & -1.05 \\
\hline 51 & $4-7$ & $\begin{array}{c}\text { unnamed protein product } \\
\text { \{nonspecific hit to BACK domain\} }\end{array}$ & $\mathrm{gi} \mid 221044806$ & 23.358 & 6.88 & 34 & 91 & $11 \%$ & $3 / 14$ & 2.03 & 2.03 & -1 \\
\hline 52 & $4-7$ & $\begin{array}{l}\text { protein disulfide isomerase- } \\
\text { related protein } 5\end{array}$ & gi|1710248 & 46.512 & 4.95 & 161 & $1.7 e-011$ & $14 \%$ & $8 / 75$ & 1.62 & 1.73 & 1.07 \\
\hline 54 & \multirow[t]{2}{*}{$4-7$} & $\begin{array}{c}\text { unnamed protein product } \\
\text { \{specific hit to actin\} }\end{array}$ & gi|194376310 & 38.950 & 5.19 & 116 & $5.5 e-007$ & $18 \%$ & $8 / 75$ & \multirow[t]{2}{*}{1.71} & \multirow[t]{2}{*}{2.27} & \multirow[t]{2}{*}{1.32} \\
\hline 55 & & ACTB protein* & gi|15277503 & 40.536 & 5.55 & 84 & 0.00081 & 10 & $5 / 75$ & & & \\
\hline 56 & $4-7$ & $\begin{array}{l}\text { unnamed protein product \{specific } \\
\text { hit to actin domain\} }\end{array}$ & gi|194376310 & 38.950 & 5.19 & 65 & 0.069 & $15 \%$ & $6 / 48$ & 2.12 & 3.19 & 1.51 \\
\hline 63 & \multirow{2}{*}{$4-7$} & zinc finger protein 441 & gi|119604646 & 78.130 & 8.95 & 52 & 1.3 & $9 \%$ & $6 / 17$ & \multirow{2}{*}{-1.32} & \multirow{2}{*}{-1.56} & \multirow{2}{*}{-1.18} \\
\hline 64 & & tyrosine hydroxylase & gi|548153 & 3.717 & 8.31 & 35 & 63 & $73 \%$ & $3 / 16$ & & & \\
\hline 65 & $4-7$ & $\begin{array}{l}\text { immunoglobulin heavy chain } \\
\text { variable region }\end{array}$ & gi|27650504 & 8.847 & 8.07 & 30 & $2.4 \mathrm{e}+002$ & $23 \%$ & $4 / 75$ & -1.41 & -1.59 & -1.13 \\
\hline 68 & $4-7$ & $\begin{array}{c}\text { Chain A, Crystal Structure Of } \\
\text { Human P32, A Doughnut-Shaped } \\
\text { Acidic Mitochondrial Matrix } \\
\text { Protein } \\
\end{array}$ & gi|4930073 & 23.844 & 4.32 & 141 & $1.7 e-009$ & $32 \%$ & $6 / 75$ & 1.61 & 1.75 & 1.09 \\
\hline 69 & $4-7$ & $\begin{array}{l}\text { unnamed protein product }\{\text { match } \\
\text { to } \mathrm{Zn} \text { finger } 285 \mathrm{~A} \text { protein\} }\end{array}$ & gi|16550013 & 51.777 & 8.85 & 35 & 68 & $8 \%$ & $4 / 16$ & -1.3 & -1.52 & -1.16 \\
\hline 70 & $4-7$ & $\begin{array}{c}\text { immunoglobulin heavy chain } \\
\text { variable region }\end{array}$ & gi|21999882 & 6.980 & 5.04 & 37 & 41 & $56 \%$ & $4 / 75$ & -1.44 & -1.52 & -1.06 \\
\hline 72 & $4-7$ & $\begin{array}{c}\text { similar to RIKEN CDNA } \\
1700016 \mathrm{G} 05, \text { isoform CRA_c }\end{array}$ & gi|119604393 & 25.383 & 9.19 & 34 & 89 & $15 \%$ & $3 / 15$ & -2.26 & -1.88 & 1.2 \\
\hline 74 & $4-7$ & CALD1 protein & gi|116283250 & 17.756 & 9.69 & 39 & 30 & $20 \%$ & $4 / 15$ & -1.25 & -1.57 & -1.26 \\
\hline 77 & $4-7$ & STK35 protein & gi|84798766 & 28.027 & 7.78 & 33 & $1.1 \mathrm{e}+002$ & $16 \%$ & $8 / 74$ & -1.26 & -1.66 & -1.32 \\
\hline 78 & $4-7$ & complement receptor & gi|395334 & 3.082 & 9.22 & 37 & 47 & $44 \%$ & $2 / 14$ & 2.91 & 1.63 & -1.79 \\
\hline
\end{tabular}




\begin{tabular}{|c|c|c|c|c|c|c|c|c|c|c|c|c|}
\hline \multirow[b]{2}{*}{$\begin{array}{c}\text { Spot } \\
\#\end{array}$} & \multirow[b]{2}{*}{ pH } & \multirow[b]{2}{*}{ Name } & \multirow[b]{2}{*}{ gi \# } & \multirow[b]{2}{*}{$\begin{array}{c}\text { Calc. Mw } \\
\text { (kDa) }\end{array}$} & \multirow[b]{2}{*}{ Calc. pl } & \multirow[b]{2}{*}{ Score } & \multirow[b]{2}{*}{ Expect. } & \multirow[b]{2}{*}{$\begin{array}{c}\text { Seq. cov. } \\
\text { (\%) }\end{array}$} & \multirow[b]{2}{*}{$\begin{array}{c}\text { Matched } \\
\text { /total }\end{array}$} & \multicolumn{3}{|c|}{ Fold change } \\
\hline & & & & & & & & & & $\begin{array}{l}\text { YTX/ } \\
\text { MeOH }\end{array}$ & $\begin{array}{l}\text { dsYTX/ } \\
\text { MeOH }\end{array}$ & dsYTX/YTX \\
\hline 79 & $4-7$ & $\begin{array}{c}\text { CDC28 protein kinase regulatory } \\
\text { subunit } 1 \mathrm{~B}\end{array}$ & gi|55960117 & 8.079 & 5.88 & 47 & 4 & $38 \%$ & $3 / 16$ & 3.14 & 1.91 & -1.64 \\
\hline 80 & $4-7$ & $\begin{array}{c}\text { T cell receptor } V \text { alpha } 9.1=\text { specific } \\
\text { for mycobacterial heat shock } \\
\text { protein } 60 \text {-derived peptide P1 } \\
\text { \{clone } 2.4, \text { complementarity- } \\
\text { determining region } 3 \text { \} [human, } \\
\text { peripheral blood T cells, Peptide } \\
\text { Partial, } 29 \text { aa] }\end{array}$ & gi|1086967 & 3.287 & 10.05 & 33 & $1.1 \mathrm{e}+002$ & $75 \%$ & $3 / 75$ & 2.12 & 1.22 & -1.74 \\
\hline 82 & $4-7$ & $\begin{array}{c}\text { signal recognition particle 9kDa, } \\
\text { isoform CRA_c }\end{array}$ & gi|119590159 & 5.570 & 6.54 & 31 & $1.8 \mathrm{e}+002$ & $34 \%$ & $2 / 21$ & 3.26 & 2.1 & -1.55 \\
\hline 84 & $4-7$ & unnamed protein product & gi|194380768 & 19.682 & 11.21 & 32 & $1.5 \mathrm{e}+002$ & $17 \%$ & $5 / 75$ & 2.17 & 1.43 & -1.51 \\
\hline 89 & $4-7$ & $\begin{array}{c}\text { Unknown } \text { \{specific hit to } \alpha \\
\text { crystalline domain found in small } \\
\text { HSP } \alpha \text { B crystalline. sHSPs are } \\
\text { molecular chaperones, protect } \\
\text { against cell stress }\end{array}$ & gi| 2852648 & 22.435 & 7.18 & 36 & 62 & $15 \%$ & $3 / 14$ & -1.21 & -1.53 & -1.26 \\
\hline 90 & $4-7$ & $\begin{array}{l}\text { Full=MIF4G domain-containing } \\
\text { protein; AltName: Full=SLBP- } \\
\text { interacting protein 1; Short=hSLIP1 }\end{array}$ & gi|189081938 & 25.749 & 5.23 & 30 & $2.4 \mathrm{e}+002$ & $9 \%$ & $2 / 5$ & -1.26 & -1.66 & -1.31 \\
\hline 92 & $4-7$ & $\begin{array}{l}\text { immunoglobulin heavy chain } \\
\text { variable region }\end{array}$ & gi|112698573 & 11.110 & 9.10 & 42 & 13 & $32 \%$ & $3 / 19$ & 1.74 & 2.17 & 1.24 \\
\hline 96 & $6-11$ & $\begin{array}{c}\text { unnamed protein product \{specific } \\
\text { hit K homology RNA-binding } \\
\text { domain, type I. KH binds ss } \\
\text { RNA/DNA }\end{array}$ & gi|194377024 & 70.150 & 9.47 & 67 & 0.043 & $8 \%$ & $8 / 12$ & -1.7 & -1.39 & 1.22 \\
\hline 100 & $6-11$ & $\begin{array}{l}\text { hCG1647242 \{specific hit to } \\
\text { Bel/Pao family of RNase } \mathrm{HI} \text { in long- } \\
\text { term repeat retroelements\} }\end{array}$ & gi|119612025 & 58.863 & 9.16 & 26 & $5.9 e+002$ & $17 \%$ & $4 / 50$ & 2.23 & 3.06 & 1.37 \\
\hline 101 & $6-11$ & hCG2042223 \{ch/some 1$\}$ & gi|119615331 & 8.095 & 11.92 & 45 & 6.8 & $38 \%$ & $3 / 16$ & 1.92 & 2.47 & 1.29 \\
\hline 102 & $6-11$ & tyrosine hydroxylase & gi|548153 & 3.717 & 8.31 & 32 & $1.3 e+002$ & $73 \%$ & $2 / 21$ & 1.68 & 2.13 & 1.27 \\
\hline
\end{tabular}




\begin{tabular}{|c|c|c|c|c|c|c|c|c|c|c|c|c|}
\hline \multirow[b]{2}{*}{$\begin{array}{c}\text { Spot } \\
\#\end{array}$} & \multirow[b]{2}{*}{$\mathrm{pH}$} & \multirow[b]{2}{*}{ Name } & \multirow[b]{2}{*}{ gi \# } & \multirow[b]{2}{*}{$\begin{array}{l}\text { Calc. Mw } \\
\text { (kDa) }\end{array}$} & \multirow[b]{2}{*}{ Calc. pl } & \multirow[b]{2}{*}{ Score } & \multirow[b]{2}{*}{ Expect. } & \multirow[b]{2}{*}{$\begin{array}{c}\text { Seq. cov. } \\
\text { (\%) }\end{array}$} & \multirow[b]{2}{*}{$\begin{array}{c}\text { Matched } \\
\text { /total }\end{array}$} & \multicolumn{3}{|c|}{ Fold change } \\
\hline & & & & & & & & & & $\begin{array}{l}\text { YTX/ } \\
\text { MeOH }\end{array}$ & $\begin{array}{l}\text { dsYTX/ } \\
\text { MeOH }\end{array}$ & dsYTX/YTX \\
\hline 106 & $6-11$ & nucleolin, isoform CRA_c & gi|119591368 & 58.576 & 4.57 & 208 & $3.5 e-016$ & $18 \%$ & $14 / 75$ & 1.63 & 1.72 & 1.05 \\
\hline 107 & $6-11$ & HNRNPA1 protein & gi|75517570 & 29.482 & 9.19 & 131 & $1.7 e-008$ & $26 \%$ & $9 / 75$ & 1.41 & 1.7 & 1.21 \\
\hline 114 & $6-11$ & transgelin 2, isoform CRA_a & gi|119573144 & 19.458 & 8.87 & 49 & 2.9 & $35 \%$ & $7 / 75$ & -1.43 & -1.71 & -1.19 \\
\hline 115 & $6-11$ & apolipoprotein $\mathrm{M}$, isoform CRA_b & gi|119623867 & 18.021 & 8.52 & 43 & 10 & $22 \%$ & $7 / 75$ & -1.38 & -1.54 & -1.11 \\
\hline 118 & $6-11$ & $\begin{array}{l}\text { unnamed protein product \{gene } \\
\text { region Rossmann-fold NADP(+)- } \\
\text { binding protein; highly similar to } \\
\text { pyruvate dehydrogenase regulatory } \\
\text { subunit, mRNA\} }\end{array}$ & gi|193788467 & 32.249 & 9.61 & 30 & $2 e+002$ & $15 \%$ & $2 / 7$ & 1.26 & 2.23 & 1.77 \\
\hline
\end{tabular}




\section{Appendix J}

The top ranked protein identification for each picked protein spots from HL60 experiment which had a significant match score, but were not identified as changing by 2D-DIGE analysis. *Indicates a protein identification which is the best match (including $\mathrm{Mw}, \mathrm{pl}$ ), but is not the top-ranked identification.

\begin{tabular}{|c|c|c|c|c|c|c|c|c|c|c|c|c|}
\hline \multirow[b]{2}{*}{$\begin{array}{c}\text { Spot } \\
\#\end{array}$} & \multirow[b]{2}{*}{ pH } & \multirow[b]{2}{*}{ Name } & \multirow[b]{2}{*}{ gi \# } & \multirow[b]{2}{*}{$\begin{array}{l}\text { Calc. Mw } \\
\text { (kDa) }\end{array}$} & \multirow[b]{2}{*}{ Calc. pl } & \multirow[b]{2}{*}{ Score } & \multirow[b]{2}{*}{ Expect. } & \multirow[b]{2}{*}{$\begin{array}{l}\text { Seq. cov. } \\
\text { (\%) }\end{array}$} & \multirow[b]{2}{*}{$\begin{array}{l}\text { Matched } \\
\text { /total }\end{array}$} & \multicolumn{3}{|c|}{ Fold change } \\
\hline & & & & & & & & & & $\begin{array}{l}\text { YTX/ } \\
\text { MeOH }\end{array}$ & $\begin{array}{l}\text { dsYTX/ } \\
\text { MeOH }\end{array}$ & dsYTX/YTX \\
\hline \multirow[t]{2}{*}{01} & \multirow[t]{2}{*}{$4-7$} & $\begin{array}{l}\text { unnamed protein product \{hits to } \\
\text { DNA K molecular chaperone, highly } \\
\text { similar to HSP70 mitochondrial } \\
\text { protein }\}\end{array}$ & gi|221039760 & 47504 & 6.20 & 253 & $1.1 \mathrm{e}-020$ & $32 \%$ & $19 / 75$ & 1.23 & 1.43 & 1.16 \\
\hline & & MTHSP75* & gi|292059 & 74019 & 5.97 & 229 & $2.8 \mathrm{e}-018$ & $21 \%$ & $19 / 75$ & 1.06 & 1.2 & 1.14 \\
\hline \multirow{2}{*}{02} & \multirow{2}{*}{$4-7$} & $\begin{array}{c}\text { Chain A, Crystal Structure Of } \\
\text { Hsc70BAG1 IN COMPLEX WITH ATP }\end{array}$ & gi|225698069 & 42120 & 6.38 & 154 & 8.7e-011 & $21 \%$ & $11 / 75$ & \multirow{2}{*}{-1.24} & \multirow{2}{*}{-1.13} & \multirow{2}{*}{1.1} \\
\hline & & $\begin{array}{c}\text { heat shock } 70 \mathrm{kDa} \text { protein } 8 \text { isoform } \\
1 \text { variant* }\end{array}$ & gi|62897129 & 71083 & 5.28 & 151 & $1.7 e-010$ & $15 \%$ & $13 / 75$ & & & \\
\hline 03 & $4-7$ & $\begin{array}{c}\text { unnamed protein product }\{\text { matches } \\
\text { to protein disulfide isomerise (PDI) } \\
\text { a, a', b, b' families; ER\} }\end{array}$ & gi|194373909 & 51620 & 4.77 & 186 & $5.5 e-014$ & $21 \%$ & $14 / 75$ & -1.12 & 1.09 & 1.22 \\
\hline 04 & $4-7$ & Chaperonin (HSP60) & gi|31542947 & 61187 & 5.70 & 220 & $2.2 \mathrm{e}-017$ & $31 \%$ & $20 / 75$ & -1 & 1.26 & 1.26 \\
\hline 05 & $4-7$ & $\begin{array}{c}\text { Chain A, TapasinERP57 } \\
\text { heterodimer (nb: ERP is part of PDI } \\
\text { family) }\end{array}$ & gi|220702506 & 54541 & 5.61 & 301 & $1.7 \mathrm{e}-025$ & $24 \%$ & $19 / 75$ & 1.05 & 1.2 & 1.14 \\
\hline
\end{tabular}




\begin{tabular}{|c|c|c|c|c|c|c|c|c|c|c|c|c|}
\hline \multirow{2}{*}{$\begin{array}{c}\text { Spot } \\
\#\end{array}$} & \multirow[b]{2}{*}{ pH } & \multirow[b]{2}{*}{ Name } & \multirow[b]{2}{*}{ gi \# } & \multirow[b]{2}{*}{$\begin{array}{l}\text { Calc. Mw } \\
\text { (kDa) }\end{array}$} & \multirow[b]{2}{*}{ Calc. pl } & \multirow[b]{2}{*}{ Score } & \multirow[b]{2}{*}{ Expect. } & \multirow{2}{*}{$\begin{array}{l}\text { Seq. } \\
\text { cov. } \\
(\%)\end{array}$} & \multirow[b]{2}{*}{$\begin{array}{l}\text { Matched } \\
\text { /total }\end{array}$} & \multicolumn{3}{|c|}{ Fold change } \\
\hline & & & & & & & & & & $\begin{array}{l}\text { YTX/ } \\
\text { MeOH }\end{array}$ & $\begin{array}{l}\text { dsYTX/ } \\
\text { MeOH }\end{array}$ & $\begin{array}{c}\text { dsYTX/Y } \\
\text { TX }\end{array}$ \\
\hline 06 & $4-7$ & $\begin{array}{l}\text { unnamed protein product \{specific } \\
\text { hit to } \beta \text { tubulin\} }\end{array}$ & gi|221045918 & 46936 & 4.83 & 118 & $3.5 e-007$ & $30 \%$ & $21 / 75$ & -1.06 & -1.16 & -1.1 \\
\hline 07 & $4-7$ & $\begin{array}{l}\text { unnamed protein product \{specific } \\
\text { hit to } \beta \text { tubulin\} }\end{array}$ & gi|221045918 & 46936 & 4.83 & 99 & $2.6 e-005$ & $27 \%$ & $19 / 75$ & -1.14 & -1.18 & -1.04 \\
\hline \multirow{2}{*}{08} & \multirow{2}{*}{$4-7$} & $\begin{array}{c}\text { unnamed protein product ffrom } \\
\text { tubulin Ftsz region\} }\end{array}$ & gi|194387512 & 20259 & 4.39 & 74 & 0.0095 & $19 \%$ & $3 / 75$ & \multirow{2}{*}{1.23} & \multirow{2}{*}{1.35} & \multirow{2}{*}{1.1} \\
\hline & & $\begin{array}{l}\text { unnamed protein product \{specific } \\
\text { hit to } \alpha \text { tubulin\} }\end{array}$ & gi|221039556 & 58636 & 4.94 & 71 & 0.017 & $9 \%$ & $3 / 75$ & & & \\
\hline 09 & $4-7$ & $\begin{array}{c}\text { unnamed protein product^ } \\
\text { \{specific hit to } \alpha \text { tubulin\} }\end{array}$ & gi|221039556 & 58636 & 4.94 & 91 & 0.00018 & $5 \%$ & $2 / 75$ & -1.32 & -1.38 & -1.05 \\
\hline 010 & $4-7$ & $\begin{array}{l}\text { unnamed protein product } \\
\text { \{specific hit to actin\} }\end{array}$ & gi|194375299 & 37667 & 5.49 & 239 & $2.8 \mathrm{e}-019$ & $19 \%$ & $5 / 20$ & -1.12 & -1.16 & -1.04 \\
\hline 011 & $4-7$ & $\begin{array}{l}\text { unnamed protein product \{specific } \\
\text { hit to actin\} }\end{array}$ & gi|194375299 & 37667 & 5.49 & 226 & $5.5 e-018$ & $33 \%$ & $14 / 75$ & -1.25 & -1.28 & -1.02 \\
\hline \multirow[t]{2}{*}{012} & \multirow[t]{2}{*}{$6-11$} & \multirow{2}{*}{$\begin{array}{c}\text { Chain A, Crystal Structure Of } \\
\text { Human Phosphoglycerate Kinase } \\
\text { Bound To D-Adp/phosphoglycerate } \\
\text { kinase 1, isoform CRA_b }\end{array}$} & \multirow{2}{*}{ gi|193506632 } & \multirow[t]{2}{*}{45266} & \multirow[t]{2}{*}{8.32} & \multirow[t]{2}{*}{288} & \multirow[t]{2}{*}{$3.5 e-024$} & \multirow[t]{2}{*}{$24 \%$} & \multirow[t]{2}{*}{$13 / 75$} & 1.32 & -1.03 & -1.36 \\
\hline & & & & & & & & & & -1.03 & -1.06 & -1.03 \\
\hline 013 & $6-11$ & $\begin{array}{c}17 \mathrm{kDa} \text { cyclophilin } \mathrm{A} \text { \{internal } \\
\text { fragment } \text { [human, first trimester } \\
\text { decidual and placental tissue, } \\
\text { Peptide Partial, } 29 \text { aa] }\end{array}$ & gi|1041969 & 3190 & 4.10 & 127 & $4.4 \mathrm{e}-008$ & $62 \%$ & $2 / 75$ & -1.09 & -1.21 & -1.1 \\
\hline
\end{tabular}

